\title{
DE STANDEN BIJ DE BOEGINEEZEN EN MAKASSAREN.
}

DOOR

\author{
H. J. FRIEDERICY.
}

\begin{abstract}
EERSTE HOOFDSTUK.
De indeeling in standen.

- „De handhaving van de standen is een der voorwaarden tot het groot maken van een land”. - „De voorspoed van een land is afhankelijk van vier zaken, die, na onze omhelzing van den Islam, door toevoeging van de „sara", tot vijf zijn vermesrderd: ten eerste de ,adě” (de oude gewoonten), ten tweede de ,oendang” (de wetten), ten derde de ,bitjara” (de rechtspraak), ten vierde de ,wari'” (de indeeling in standen), en ten vijfde de ,sara'” (de Mohamedaansche wet)".
\end{abstract}

Uit de „Latowa".

I.

De indeeling in standen is bij de Boegineezen en Makassaren zonder twijfel de belangrijkste niet-locale maatschappelijke groepeeringsvorm. $\mathrm{Zij}$ is in hooge mate opvallend en hoe langer men in het land verblijf houdt, hoe meer men er van doordrongen raakt, dat de deeling in standen het geheele sociale, economische en religieuze leven, zoo niet beheerscht, dan toch in sterke mate beinvloedt. Hoe nivelleerend het Westersch bestuur ook moge gewerkt hebben, toch treedt de indeeling in standen nog overal scherp en duidelijk aan den dag. Het ligt niet in mijn bedoeling hier den invloed van het Nederlandsch bewind op deze groepeering na te gaan, laat staan volledig te behandelen. Dit hoofdstuk, en trouwens ook de volgende, zouden in een politieke verhandeling ontaarden. Toch zal ik niet kunnen nalaten er eenige woorden over te zeggen.

Wil men een eenigszins dieper inzicht verwerven in het standensysteem der twee hier behandelde volken, dan is men al spoedig genoodzaakt zich van het heden af te wenden en een onderzoek in te stellen naar den toestand vóór de meer daadwerkelijke inmenging der Hollanders in den gang van zaken op Zuid-Celebes. Naar den

D1. 90. 
toestand dus van vóór 1906. Wel was reeds te dien tijde het tegenwoordig zoogenaamd rechtstreeks bestuurde gebied $^{1}$ ), met uitzondering van het Gowasche rijk, aan het Hollandsche gezag onderworpen, en dat al sedert tientallen en tientallen van jaren, doch een blik in de geschiedenis van Zuid-Celebes schenkt de overtuiging, dat het met dat gezag en die onderwerping van vóór 1906, een voortdurend vallen en opstaan is geweest. Eerst na dat jaar treedt het Westersche gezag ingrijpend regelend op en vervagen, langzaam doch gestadig, door duizend-en-één maatregelen uitgaande van dat gezag, en later ook door economische en andere invloeden, de tegenstellingen in de Makassaarsche en Boegineesche samenleving, de tegenstellingen, die nergens sterker tot uiting kwamen en nog komen, dan in het standensysteem. Het vermelden van slechts enkele feiten is voldoende om te beseffen, welke hevige slagen aan de aloude indeeling in standen werden toegebracht. In 1906, bij het einde van de Zuid-Celebes-expeditie, hebben de twee voornaamste rijken, Gowa en Bone, geen vorst meer. Karaëng Lembangparang, de vorst van Gowa, is op zijn vlucht, bij een val in een ravijn, om het leven gekomen en Lapawawoï, de vorst van Bone, is verbannen naar Java. $\mathrm{Zij}$ worden niet vervangen en de beide toonaangevende vorstenhoven houden op te bestaan. De regalia van Gowa en Bone worden verdeeld onder de musea van Amsterdam, Leiden en Batavia. De bloem van den adel raakt in verval, meegesleept in den ondergang der voornaamste vorstenhuizen. De slavernij, in naam reeds lang tot het verleden behoorend, vindt na 1906 definitief haar einde, al is tot op den huidigen dag de band tusschen de afstammelingen der oude meesters en de afstammelingen der oude slaven - waarover straks meer - nog zeer hecht. Zooals ik zeide, beperk ik mij tot het vermelden van slechts enkele feiten, doch deze zullen het reeds duidelijk maken dat de huidige toestanden in Zuid-Celebes, door welke gewenschte of ongewenschte oorzaken dan ook, geen zuiver beeld meer kunnen opleveren van het, aan het einde van de 19de eeuw nog bestaande standenstelsel.

Voor vele gegevens, die ik hieronder zal groepeeren, moest ik dan ook gebruik maken van mij door Makassaren en Boegineezen gedane mededeelingen, die betrekking hadden op een tijd die de mijne niet was. Met enkelen van hen kwam ik op vertrouwelijken, met zeer enkelen op vriendschappelijken voet te staan. Ik noem den tegen-

1) Dit in tegenstelling met het indirect bestuurde gebied, dat ingenomen wordt door de zelfbesturen onder politiek contract. 
woordigen vorst van Bone ${ }^{\mathbf{1}}$ ), Mappanjoeki - in mijn tijd hoofd van het voormalige Gowasche vorstenhuis -; den Tomarilalĕng of Rijksbestuurder van Bone, Madoesila daëng Paraga; Pasinringi daëng Matanga Aroe Taneti-ri-attang, Mappasere Aroe Ta', Baso Aroe Pontjeng, allen leden van den rijksraad van Bone; Abdurradjah daëng Masikki, bestuursassistent; Noesoe daëng Manangkasi, bestuursassistent; Sonda daëng Mattajang, djaksa en Sommeng Aroe Kahoe. Zoo zal ik ook, wat ik wetenswaardigs vond bij schrijvers van vóór 1906, - al zijn die ook bijzonder zwijgzaam op het stuk van standen - , dankbaar aanwenden, onder vermelding van de plaatsen. Voorts moet ik gewag maken van het feit dat ik, ciank zij de welwillendheid van den heer Mr. F. D. E. van Ossenbruggen, gebruik heb kunnen maken van de nagelaten aanteekeningen van wijlen mijn kameraad en collega Dr. J. Mallinckrodt, welke aanteekeningen door Mevrouw L. Mallinckrodt-Djata ter beschikking van de Commissie voor Adatrecht zijn gesteld. Het is uit deze aanteekeningen, dat ik de gegevens omtrent Mandar heb geput. De hier medegedeelde gegevens over de indeeling der standen in Wadjo', vond $\mathrm{ik}$ in een, zich bij de aanteekeningen van Mallinckrodt bevindenden brief van den toenmaligen controleur van Wadjo', M. van Rhijn, aan den Assistent-Resident van Bone. Waar de door mij op dit punt in Bone verzamelde gegevens niet zoo volledig zijn als deze, en mij bovendien bekend is, dat de indeeling der standen in Bone, Wadjo' en Soppeng vrijwel overeenkomt, aarzel ik niet om aan de gegevens van den heer van Rhijn, wiens uiterst conscientieuze wijze van onderzoeken mij bekend is, de voorkeur te geven boven die van mij zelf. Ook is door mij gebruik gemaakt van een van de belangrijkste geschriften der Boegineesche letterkunde, namelijk de „Latowa”, „de Oude", een verzameling van gezegden van oude Boegineesche vorsten en wijzen over allerlei onderwerpen, doch vooral over de verplichtingen van vorsten en hoofden jegens hunne onderdanen en van dezen ten opzichte van genen. Over den ouderdom van den „Latowa” verkeert men in het onzekere en ook de schrijvers - want het zijn

1) In April 1931 kreeg Bone wederom cen vorst en werden ook de rijkssieraden door het Gouvernement teruggegeven. Deze vorst leeft evenwel in zulke gewijzigde omstandigheden, dat van een hofhouding in den ouden zin van het woord, geen sprake kan zijn. Zooals vanzelf spreekt is ook zijn positie een geheel andere geworden dan die van zijn voorganger. Toch heeft deze daad van het Gouvernement, die er een was aan het einde van een lange reeks van daden, ten doel hebbende de verzwakte positie der hoofden te herstellen, het aanzien van den adel ten zeers.e verhoogd. 
er ongetwijfeld meer dan een geweest - zijn onbekend. De invloed van den Islam op het werk is onmiskenbaar. Daar historisch vaststaat, dat de Islam eerst in het begin van de 17 de eeuw zijn intrede op Zuid-Celebes heeft gedaan, kan de „Latowa”, zooals hij thans is, niet ouder dan ongeveer drie eeuwen zijn. Er bestaan, naar men zegt, verschillende redacties van. Dr. Matthes bemachtigde een ongeveer 300 pagina's groot handschrift, waarvan hij een gedeelte in zijn Boegineesche Chrestomathie ${ }^{1}$ ) uitgaf. Op dit uitgegeven gedeelte baseerde hij grootendeels zijn: „Over de âda's of gewoonten der Makassaren en Boegineezen" ").

Ook Niemann wijdde aan ditzelfde gedeelte een $\left.\operatorname{artikel}^{3}\right)$. De rest van het handschrift werd tot dusver nog niet gepubliceerd. Ik gebruikte de te Watampone op het bestuurskantoor aanwezige Maleische vertaling van den heer Toepoe daëng Mapoeli, oud-hoofdonderwijzer. Voor zoover ik hierover kan oordeelen en naar men mij van bevoegde zijde verzekerde, is deze vertaling uiterst betrouwbaar en vrijwel woordelijk te noemen. Dit geschrift zou, naar voorin aangeteekend staat, ,de complete „Latowa” van Dr. Matthes” zijn.

Waar ik het uitdrukkelijk noemen van een bron achterwege laat, zijn mijn mededeelingen gegrond op eigen onderzoek of ervaring.

II.

Het is een bekend feit, dat men zich niet tot de primitieven zelf moet wenden om ten aanzien van welken groepeeringsvorm dan ook, een overzichtelijk schema te verkrijgen. Bij de Boegineezen en Makassaren is het niet anders.

Bij het lezen van den „Latowa” viel het mij op, dat de directe beschrijving van eigen sociaal systeem ook hier vrijwel geheel ontbreekt. Dit schijnt op het eerste gezicht te merkwaardiger, omdat vele gedeelten juist de maatschappelijke betrekkingen tot onderwerp hebben en vermaningen behelzen aan den vorst, zoo goed als aan den slaaf van den vorst. De hofétiquette wordt uitgebreid behandeld en ook kan men er lezen, hoe de familieleden van den vorst door voorbeeldigen levenswandel hebben te waken voor de eer en den goeden

1) Dr. B. F. Matthes. Boegineesche Chrestomathie, Makasser, 1864, 2de uitg., A'dam, 1872.

2) Versl. en Meded. Kon. Ak. van Wet. Amsterdam; afd. Lett., derde reeks, deel 2 (1885), blz. 137-189. Thans ook in Adatrechtbundel XXXI.

3) Bijdr. Kon. Inst. 32 (1884), blz. 198-228. Thans ook in Adatrechtbundel XXXI. 
naam van hun heer. Kortom, allerlei groepen komen ter sprake, doch aan eenige rangschikking dezer groepen bestaat bij de schrijvers blijkbaar geen behoefte, al streven zij overigens zeer naar juiste definities en onderscheidingen, in den trant van: „Een goed vorst is hij, die vijf zaken in het oog houdt, te weten...”, of „Hij die aan het hof verkeert, dient veertien zaken steeds indachtig te zijn, namelijk..."

In verband met het bovenstaande behoeft het geen betoog, dat het schema van een of andere sociale groepeering bij een primitief volk noodzakelijk het stempel zal moeten dragen van dengeen, die dat schema heeft opgesteld; in eerste instantie van den onderzoeker dus. Deze omstandigheid zal het mij aanstonds mogelijk maken een kenmerkend verschil te verklaren tusschen de schema's door Mallinckrodt en van Rhijn, respectievelijk voor Mandar en Wadjo' opgesteld, en het schema dat ik zelf voor Gowa -maakte.

\section{III $\left.{ }^{1}\right)$.}

\section{Mandar ${ }^{2}$ ).}

Mallinckrodt noemt als grondslag van de indeeling in standen drie groepen, en wel: A. Zij met meer of minder vorstenbloed, B. de vrijen, en C. de slaven.

De eerste en hoogste hoofdgroep, waarvan de leden tezamen de „Todiang lajana” ${ }^{3}$ ), d.w.z. „,de menschen, die vorstenbloed hebben,” heeten, is onderverdeeld in vijven. De eerste en voornaamste, de „Aradjang” genaamd, is de groep, die gevormd wordt door den regeerenden vorst of vorstin, in Mandar een "Maradia”, en zijn of haar nageslacht van zuiveren bloede. De tweede groep is die der „Ana matola padjoeng”, de ,opvolgers van het zonnescherm”, de nakomelingen van zuiveren bloede van vroegere vorsten of vorstinnen. De derde groep is die van de „Maradia talloe parapa”, de „,driekwart-maradia's", die gesproten zijn uit huwelijken van mannen uit de eerste of de tweede groep met vrouwen uit de groep der "Taoe pea nae", waarover hieronder nader. De vierde groep is de groep

1) De in dit gedeelte voorkomende beschrijvingen hebben, hoewel gesteld in den tegenwoordigen tijd, betrekking op de toestanden omstreeks 1900. Lang genoeg geleden dus om Westersche invloeden op dezen groepeeringsvorm, althans in de te behandelen streken, uit te sluiten, en nabij genoeg om een alleszins betrouwbare reconstructie dier toestanden mogelijk te maken.

2) Ontleend aan de nagelaten aanteekeningen van Dr. J. Mallinckrodt.

3) Spelling der inhesmsche termen van Mallinckrodt. 
der „Poewasasigi”, de ,halve heeren”, gesproten uit huwelijken van mannen uit de tweede groep met vrouwen uit de groep der „Taoe pea" in engeren zin, de groep, die onmiddellijk volgt op de evengenoemde groep der ,Taoe pea nae”. De vijfde groep tenslotte bestaat uit de „Poewasiparapa”, de „kwart-heeren”. Zij hebben een lid uit de tweede groep tot vader en een slavin tot moeder.

Tot de tweede hoofdgroep rekent men, volgens Mallinckrodt, niet alleen de massa der vrije bevolking, doch ook den lageren adel. Deze hoofdgroep der „Taoe Maradeka”, der ,,vrijen”, is onderverdeeld in twee groepen: die der "Taoe pea”, die Mallinckrodt vergelijkt met onzen regentenadel en die der "Taoe samar”, der ,gemeene lieden”. De groep der "Taoe pea” is weer verdeeld in twee ondergroepen: de groep der „Taoe pea nae”, bestaande uit de leden der hoogere hoofdengeslachten, zooals de ,pabitjara”-geslachten en de ,papoeangan"-geslachten, en de groep der ,Taoe pea” in engeren zin, gevormd door de geslachten der lagere hoofden, zooals de ,bali padja's", de „,tomatowa's" en dergelijke ,medebestuurderen en kiesheeren”. De ,Taoe samar" vormen de groote massa der bevolking.

De derde hoofdgroep is die van de slaven, de „Batoewa”. Deze verdeelt Mallinckrodt in twee groepen, namelijk de „batoewa niali”, de ,nieuwe slaven”, én de ,batoewa sasorang”, de erfslaven, de „slaven van den bloede".

Ten aanzien van de pandelingen zijn Mallinckrodt's aanteekeningen niet duidelijk. Hij noemt de groep der ,,schuldslaven”, ,batoewa inranang" genaamd, en teekent daarbij aan, dat deze vaak in ,slavernii” zijn geraakt met hun gezin zonder aanzien van den stand, waartoe zij behoorden. $Z \mathrm{ij}$ worden veelal verzorgd ten huize van den schuldeischer en blijven in erfelijke dienstbaarheid tot de schuld geheel betaald is. De vruchten van hun arbeid komen geheel aan den schuldeischer. Op een andere plaats evenwel vermeldt Mallinckrodt, dat men door pandelingschap blijkbaar niet tot den slavenstand kwam te behooren. $Z \mathrm{ij}$, die op die wijze in dienstbaarheid kwamen, vormden, naar het schijnt, een aparte groep, die vrij stond van de incleeling in standen.

Wa d jo ${ }^{1}$ ).

Van Rhijn verdeelt de Wadjosche maatschappij in vijven, t.w.

1) Ontleend aan een brief van den controleur M. van Rhịn aan den AssistentResident van Bone (1926). 
1o. de „Ana'-matola”, de „opvolgende kinderen”, 2o. de „Anakaroeng”, de „Aroe-kinderen”, 3o. de „Taoe-detjeng”, de ,goede menschen” en de „Taoe-tongěng-karadja”, welke naam voor mij niet geheel vertaalbaar is, 4o. de „Taoe-ammĕng” of „Taoe-maradeka”, de ,vrijen”, en 5o. de „Ata”, de slaven.

De eerste hoofdgroep, die der „Ana'-matola” dus, wordt weer onderverdeeld in vieren, en wel in ten eerste de groep der „Ana'matola" in engeren zin, die bestaat uit (a) hen, die van het allerzuiverste bloed zijn, en (b) hen, die geboren zijn uit een huwelijk van een man der „Ana'-matola” in engeren zin en een vrouw der „Ana'-sangadji”. De tweede groep der „Ana'-matola” (in ruimeren zin) is die der „Ana'-sangadji”, der vorstenkinderen, die gesproten zijn uit een huwelijk van een „Ana'-matola”-man met een „Ana'radjĕng”-vrouw. De derde groep is die der „Ana'-radjĕng”, een voor mij onvertaalbare naam, bestaande uit de kinderen van (a) „Ana'matola”-mannen en „Ana'-tjera-sawi”-vrouwen, en (b) „Ana'-sangadji"-mannen en „Ana'-tjera-sawi”-vrouwen. De vierde groep, welke weer in vier ondergroepen is verdeeld, is die der "Ana'-tjera”, de ,bloedkinderen”. De eerste ondergroep wordt gevormd door kinderen uit huwelijken van „Ana'-matola”-mannen met ,maradeka”vrouwen. Het is de groep der „Ana'-tjera-sawi”, welke naam voor mij onvertaalbaar is. De tweede ondergroep is die der "Ana'-tjerapoewa", welke naam eveneens voor mij niet te vertalen is, geboren uit huwelijken van „Ana'-matola"-mannen met eigen erfslavinnen. De derde ondergroep is die der ,Ana'-tjera-ampoeladjĕnn”, een alweer voor mij onvertaalbare naam, kinderen uit huwelijken van „Ana'-matola”-mannen met slavinnen van een ander. De vierde ondergroep der „Ana'-tjera” is die der „Ana'-tjera-ijatang-dapoerěng”, kinderen door „Ana'-matola” verwekt bij de laagste „slavinnen uit de keuken".

De tweede hoofdgroep is de groep der „Anakaroeng”, de „Aroekinderen”, die gesproten zijn uit verbintenissen van „Ana'-tjerasawi”-mannen en „Taoe-maradeka”-vrouwen. Tot deze groep rekenen zich in Wadjo' vele Aroe's, in dit geval hoofden van territoriale gemeenschappen, die het rijk van Wadjo' vormen, alhoewel zij, volgens van Rhijn, feitelijk behooren tot de volgende groepen.

De derde hoofdgroep is die der „,Taoe-detjeng” en de „Taoe-tongĕng-karadja”. De eersten zijn de afstammelingen van „Anakaroeng”, wier bloed nogmaals verlaagd werd. De „Taoe-tongěng-karadja” zijn dan op dezelfde wijze afstammelingen van de „Taoedetjeng”, doch 
practisch worden deze groepen niet meer onderscheiden. Tot deze hoofdgroep behooren de aanzienlijke burgers die zich „Daëng” noemen, over welken titel later meer.

De vierde hoofdgroep is die der „Taoe-amměng” of „Taoe-maradeka". Deze groep, die de groote massa omvat, is weer onderverdeeld in tweeën en wel: (a) de groep der „Taoe-maradeka-ma' nĕnnoengĕng”, de „,doorloopend vrijen”, zij die van ouder op ouder ,maradeka” zijn geweest en (b) de groep der "Taoe-maradeka-risampengi”; alweer een voor mij niet te vertalen naam ${ }^{1}$ ), slaven en hun afstammelingen, die vrijgelaten zijn.

De vijfde hoofdgroep is die der „Ata”, der slaven, waarbij men weer onderscheidt de „Ata-mana”, de erfslaven, en de „Ata-maboewang”, dat zijn vrije lieden, die tengevolge van een misdrijf slaaf zijn geworden van dengene, die hen uit den nood hielp. Werd bijvoorbeeld een dief door iemand geholpen om de waarde der gestolen goederen aan den bestolene terug te geven, dan werd deze dief slaaf van den helper. Slechts bij leening als gevolg van misdrijf kon men slaaf worden.

Voor gewone schulden kon men slechts „Sanra”, pandeling, worden. Een pandeling bleef echter tot de groep der ",maradeka” behooren, terwijl zijn kinderen altijd buiten het pandelingschap vielen.

\section{Gow a.}

In Gowa zien wij een indeeling in drie hoofdgroepen : in de eerste plaats de hoofdgroep, die het best met ,de adel” kan worden aangeduid; dan de hoofdgroep der ,vrijen” en tenslotte de hoofdgroep der ,slaven”.

De eerste hoofdgroep is te verdeelen in tweeën, namelijk in 10. de groep, die uit de leden van het vorstengeslacht van Gowa bestaat en 2o. de groep, die uit de niet-vorstelijke geslachten bestaat, waaruit de onder den vorst staande hoofden der lagere territoriale gemeenschappen stammen. Deze groep is weer onder te verdeelen in geslachten van hoogen en geslachten van lagen adel, en deze is dan wederom in een lagen adel en een laagsten adel te splitsen. Op deze wijze :

1) Ik moet aannemen, dat de beteekenis van het grootste deel dezer namen is verloren gegaan. Van Rhijn laat de namen onvertaald en ik moet, na raadpleging van Matthes' Boegineesch Woordenboek, zijn voorbeeld volgen. 
Adel.

\section{Vorstengeslacht (I). Hoofdengeslachten.}

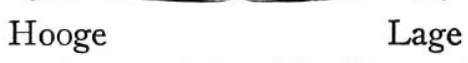

Hoofdengeslachten (II). Hoofdengeslachten.

Lage adel (III). Laagste adel(IV).

Het vorstengeslacht, de groep der vorstentelgen, der ,Ana'-karaëngs" van Gowa dus, is onderverdeeld in vier groepen: (a) die der „Ana'-tino”,, der ,rijpe, gare kinderen”, (b) die der „Ania'. sipoewé”, der ,,halve kinderen”, (c) die der „Ana'-tjera' ”, der ,,bloedkinderen”, en (d) die der „Ana'-karaëng-sala”, der ,mislukte of verkeerde vorstenkinderen".

De „Ana'-tino", zijn de vorstentelgen van het allerzuiverst bloed. ()f zij hebben een "Ana'-tino" " tot vader en een „Ana'-tino" " tot moeder, òf een van de ouders is "Ana'-tino", en de andere is een prins of prinses van het zuiverste bloed uit een gelijkwaardig vorstenhuis, zooals bijvoorbeeld Bone of Sidenreng. De mannelijke „Ana'-tino", worden in verband met de rechten tot opvolging op den Gowaschen troon onderscheiden in „Ana'-patola”, de ,opvolgende kinderen” en „Ana'-manrapi'”, de „,bereikende kinderen”. „Ana'-patola” zijn de zoons, de broeders en de volle neven van den regeerenden vorst. De „Ana'-manrapi'” zijn die mannelijke „Ana'-tino'”, die, bij ontstentenis of ongeschiktheid van „Ana'-patola” voor den Gowaschen troon in aanmerking komen.

De „Ana'-sipoewé” zijn kinderen geboren uit verbintenissen van „Ana'-tino" '-mannen en „Maradeka”-vrouwen. Men verdeelt de mannelijke „Ana'-sipoewé” in de „Ana'-sipoewé-manrapi”" en de „Ana'-sipoewé” in engeren zin. De „Ana'-sipoewé-manrapi” zijn de hooge „Ana'-sipoewé”, waarvan bijvoorbeeld de grootmoeder van moederszijde ook „Ana'-sipoewé” was, en die bij ontstentenis of ongeschiktheid van „Ana'-tino" " den Gowaschen troon zouden kunnen bestijgen. De overigen zijn de „Ana'-sipoewé” in engeren zin.

De „Ana'tjera'”, de derde groep in het vorstenhuis dus, zijn de kinderen door „Ana'-tino"” en hooge „Ana'-sipoewé” verwekt bij slavinnen.

De „Ana'-karaëng-sala”, de vierde groep, zijn door lage „Ana'sipoewé" of „Ana'-tjera'" verwekt bij slavinnen of gesproten uit verbintenissen van „Ana'-tjera'”-mannen met „Maradeka”-vrouwen. 
In de hoofdengeslachten vinden wij dezelfde verhoudingen in eenvoudiger vorm terug of liever: wij vinden, als wij goed speuren, dezelfde indeeling, doch deze is in de practijk van minder belang dan bij het vorstengeslacht. Men spreekt bij hoofdengeslachten, die zich zelf nog op peil hebben weten te houden - en dat zijn er niet zoo heel veel meer - nog wel degelijk van „Ana'-tino'”, „Ana'sipoewé" en „Ana'-tjera”" als men zoo precies mogelijk het bloedgehalte wil aanduiden. Het spreekt vanzelf, dat dergelijke onderscheidingen in hoofdengeslachten, die in bloed achteruit zijn gegaan, weinig opgeld meer doen.

De tweede hoofdgroep, die der „Taoe-maradeka”, der ,,vrijen”, kan men verdeelen in de „Taoe-badji'”, de ,goede menschen”, de welgestelden, en de „Taoe-samara”", de gemeene lieden, de ,kleine luiden".

De derde hoofdgroep, die der slaven, „Ata”, valt uiteen in twee ondergroepen. De eerste is die der "Ata-sossorang" (sossorang = erven, bij erfenis overgaan op) ook wel „Ata-poesaka” (poesaka = erfenis, erfstuk) genoemd. De erfslaven dus, wier voorvaderen van ouder op ouder in hetzelfde geslacht dienstbaar zijn geweest. Matthes vermeldt in zijn Makassaarsch woordenboek ${ }^{1}$ ) voor hen nog den naam „Ata-tai-djangang”, de ,kippendrek-slaven”. Tegenover deze groep staat die der "Ata-niboewang”, de nieuwe slaven, eigenlijk de „veroordeelde” of ,weggeworpen” slaven, dus de bij vonnis slaaf gewordenen.

De hierboven vermelde gegevens over de indeeling in standen bij de Boegineezen en Makassaren beslaan een zeer groot gedeelte van Zuid-Celebes: Mandar, een eenigszins van de andere groote rijken op Zuid-Celebes geïsoleerd gebleven statenbond, in het Noord-Westen; het gezaghebbende Wadjo', na verwant aan en buurman en bondgenoot - alhoewel de vrede vaak verstoord was - van het voornaamste Boegineesche rijk Bone, alsook van Soppeng; tenslotte het toonaangevende Makassaarsche rijk, eens oppermachtig in bijna heel den grooten Oost, de eeuwige rivaal van Bone: Gowa.

Alvorens ons te verdiepen in de verschillende standen afzonderlijk en de verhouding der standen onderling, is het wenschelijk de $i n d c c$ ling in standen, zooals deze thans voor ons ligt, nader in beschouwing te nemen. Gemakshalve stellen wij de drie schema's, zoo vereenvoudigd als mogelijk is, naast elkander.

1) Dr. B. F. Matthes, Mak.-Holl. Woordenboek, Amsterdam, 1859. 


\section{MANDAR. \\ (MALLINCKRODT).}

\section{A. „TODIANG LAJANA”.}

(,Zij die vorstenbloed hebben”).

I. De „ARADJANG”.

(de regeerende vorst en zijn geslacht).

II. De „ANA MATOLA PADJOENG".

(de "opvolgers van het zonnescherm".

Nakomelingen van zuiver bloed van vorige vorsten).

III. De „MARADIA TALLOE PARAPA".

(de "drie kwart maradia's").

IV. De „POEWA SASIGI”.

(de ,halve heeren").

V. De „POEWA SIPARAPA”.

(de „kwart heeren”).

\section{B. „TAOE MARADEKA".}

(De vrijen).

I. De „TAOE PEA”.

(,regentenadel").
a. „TAOE PEA NAE”.
(hoogere hoofdengeslachten).
b. „TAOE PEA".
(lagere hoofdengeslachten).

II. De „TAOE SAMARA".

(het gemeene volk).

\section{C. „BATOEWA”.}

(De slaven).

I. „BATOEWA SASORANG”. (erfslaven).

II. „BATOEWA NIALl”. (nieuwe slaven).

\section{[D. „BATOEWA INRANANG”. ]}




\section{WADJO.}

(VAN RHIJN).

\section{A. „ANA'-MATOLA".}

(lett. de „opvolgende kinderen”, hier: ,vorstelijke adel”).

I. De „ANA'-MATOLA".

a. "ANA'-MATOLA".

b. „ANA'-MATOLA”.

II. De „ANA'-SANGADJI”.

(de ,"vorstenkinderen").

III. De „ANA'-RADJĚNG".

a. „ANA'-RADJĚNG-LĔBBI”.

b. „ANA'-RADJĚNG”.

IV. De „ANA'-TJERA”.

(de „,bloedkinderen”).

a. „ANA'-TJERA-SAWI".

b. „ANA'-TJERA-POEWA”.

c. "ANA'-TJERA-AMPOELADJĚNG".

d. „ANA'-TJERA-IJATANG-DAPOERĚNG”.

\section{B. „ANAKAROENG”.}

(Aroekinderen).

C. I. „TAOE-DETJENG”.

II. „TAOE-TONGENG-KARADJA”. 


\section{D. „TAOE-MARADEKA”.}

(De vrijen).

I. „TAOE-MARADEKA-MA'NĔNNOENGĔNG”. (van ouder op ouder vrij).

II. „TAOE-MARADEKA-RI-SAMPENGl”. (vrij geworden slaven).

\section{E. „ATA”.}

(De slaven).

I. „ATA-MANA”. (erfslaven).

II. „ATA-MABOEWANG". (de ,weggeworpenen").

\section{$[$ F. „SANRA”." $]$}




\section{GOWA.}

\section{A. ${ }^{1 . ~ „ A N A '-K A R A E ̈ N G-R I-G O W A ” . ~}$}

(Vorstentelgen van Gowa).

I. „ANA'-TINO'”.

(De „rijpe of gare kinderen”).

a. „ANA'-PATOLA".

b. „ANA'-MANRAPI'".

(Deze indeeling geldt slechts voor mannelijke „Ana'-tino"”).

II. „ANA'-SIPOEWE”.

(De ,halve kinderen”).

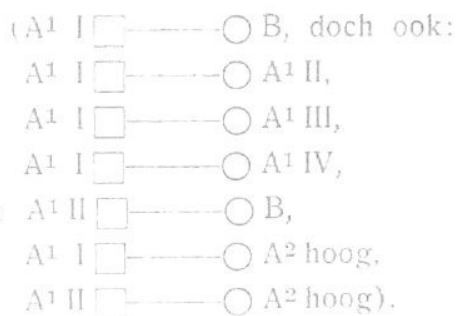

III. „ANA'-TJERA'”.

(De „bloedkinderen”).

\section{IV. „ANA'-KARAËNG-SALA”.}

(De „verkeerde karaëngskinderen”).

\section{A. 2. ANDERE „ANA'-KARAËNGS”.}

(zie schema in den tekst). 


\section{B. „TOE-MARADEKA".}

(De vrijen).

I. TOE-BADJl'. (De welgestelden).

II. TOE-SAMARA'.

(Het gemeene volk).

C. „ATA".

(De slaven).

I. „ATA-SOSSORANG”.

(De erfslaven).

II. „ATA-NIBOEWANG”.

(De ,weggeworpenen”, ,veroordeelden”).

\section{$\left[\begin{array}{l}\text { D. "TOEMANGINRANG" } \\ \text { OF „TOEMANGEMPOWANG". } \\ \text { (De pandelingen). }\end{array}\right]$}


IV.

Wanneer wij de schema's nader beschouwen, dan zien wij in het Wadjosche en het Gowasche standensysteem drie hoofdgroepen, namelijk: (1) de hoofdgroep der vorstentelgen van het zuiverste bloed, dus in Wadjo' en Gowa de A I-groep, (2) de groep der vrijen, en wel in Wadjo' de D-groep en in Gowa de B-groep, en (3) de groep der slaven, in het schema voor Wadjo' als de E-groep en in dat voor Gowa als de C-groep aangeduid. De menging van de A I-groep met de D- en E-groep, levert in Wadjo' een uiterst merkwaardig scala van tusschenstanden op. (A II t/m. IV; B en C houd ik er, om redenen die later zullen blijken, voorloopig buiten). De menging van dezelfde groep in Gowa met de B- en de C-groep schept volgens hetzelfde principe, doch eenvoudiger en minder geraffineerd, een kleiner aantal tusschenstanden. (A II $\mathrm{t} / \mathrm{m}$. IV). Bezien wij nu het schema van Mandar, dan valt het op dat, terwijl ook daar de drie hoofdgroepen duiclelijk naar voren treden, namelijk in A I en A II de vorstentelgen van zuiver bloed, in B II de vrijen en in C de slaven, de menging van de A I- en A II-groepeen met de groote, bij wijze van spreken $99 \%$ van de bevolking uitmakende groep der vrijen (B II) geen tusschenstanden in het leven heeft geroepen, zooals, ik durf wel zeggen, overal in Zuid-Celebes het geval is geweest. En tevens zien wij dan, dat deze soort tusschenstanden, die wij in de schema's van Wadjo' en Gowa zoo duidelijk aantreffen, wel ontstaan is bij de menging van de A I- en A II-groepen met de kleine B I-groep der onder het vorstengeslacht staande hoofdengeslachten, die in het schema van Mallinckrodt onder de groep der vrijen is gebracht. Ik acht het ontbreken dezer, door menging van de vorstentelgen van zuiver bloed met de vrijen ontstane tusschenstanden zoo onwaarschijnlijk, dat ik geloof, dat een nader onderzoek deze tusschenstanden, of althans overblijfselen daarvan, al spoedig aan het licht zal brengen. Vooral omdat in Mallinckrodt's schema wel voorkomt een tusschenstand, ontstaan door menging van de A I- en A IIgroepen met den slavenstand, namelijk die der ,kwart-heeren” (A V).

Voorts is het opvallend, dat zoowel in Mandar als in Wadjo' en Gowa, de menging tusschen de hoofdgroep der vrijen en die der slaven geen tusschenstanden heeft voortgebracht. Deze hoofdgroepen volgen onmiddellijk op elkander.

De tusschenstanden (Mandar A III t/m. V, Wadjo A II t/m. IV, 
Gowa A II t/m. IV) zijn in alle drie gebieden met de eerste hoofdgroep, die der zuivere vorstentelgen, in één groep vereenigd: in Mandar in de groep der „Todiang lajana”, in Wadjo' in de groep, der „Ana'-matola” in ruimen zin en in Gowa in de groep der „Ana'karaëng-ri-Gowa". Geen der tusschenstanden is in één groep ondergebracht met de vrijen, om van de slaven te zwijgen. De laagste tusschenstand is overal hooger dan de stand der vrijen.

Nadere bespreking eischen de hoofdengeslachten in verband met de vraag, welke plaats zij in het schema behooren in te nemen. Wanneer wij de karakteristiek der verschillende standen afzonderlijk gaan bespreken, zullen wij zien, dat het verschil tusschen, bij voorbeeld, het vorstengeslacht van Gowa en het hoofdengeslacht van Borisallo, een der voorname territoriale gemeenschappen, waaruit de kern van het Gowasche rijk is opgebouwd, gradueel is. Het is niet anders in Mandar en Wadjo', Bone en Soppeng, Sidenreng en Bantaëng waar men ook kijkt. De hoofdengeslachten vormen noch in Gowa, noch in Wadjo', noch in Bone een hoofdgroep in het bloedmengingsproces, als ik het zoo eens noemen mag. Alleen in Mandar zou dat, volgens Mallinckrodt, wel het geval zijn. Zooals ik het zie, vormen de hoofdengeslachten een nevengroep op de wijze als ik heb aangegeven in het schema voor Gowa. Zij staan tegenover de groepen der vrijen en slaven in den grond niet anders, dan de hoogste groep der vorstentelgen van zuiver bloed. Door de hoofdengeslachten als een nevengroep, zij het op een lager niveau, in het schema der indeeling in standen te plaatsen, wordt het beeld niet alleen helderder, doch dekt het ook de figuur der politieke structuur. Wanneer wij trachten het schema voor Wadjo' op deze wijze te zuiveren, dan vinden wij meteen de vermoedelijke oplossing van eenige onverklaarbaarheden. Wij herinneren ons, dat in Wadjo' de B-groep de groep was der „Anakaroeng”. $\mathrm{Nu}$ is een „Anakaroeng” volgens van Rhijn, en zeker ook volgens diens berichtgever of -gevers, de spruit uit een verbintenis tusschen een „Ana'-tjera-sawi”-man (A IV a $\square$ ) en een ,Maradeka"-vrouw (D O). Niet alleen dat het merkwaardig is, dat zulk een lage adelsgroep een dergelijken, goed- en volklinkenden naam draagt, want met ,arakaroeng" worden in de Boegineesche landen als Bone, Soppeng, Sindjai en de Adjatapparěng voornamelijk de leden der voorname hoofdengeslachten aangeduid, doch nog merkwaardiger is het eigenlijk dat, zooals van Rhijn zegt, vele "Aroe's" - dat zijn de hoofden der hoogere territoriale gemeenschappen D1. 90. 
waaruit Wadjo' is opgebouwd - zich tot deze groep rekenen, ,alhoewel zij feitelijk behooren tot de volgende groepen”. Deze volgende groepen zijn dan de „Taoe-detjeng” (C I), de „Taoe-tongĕngkaradja” (C II) en de „Taoe-Maradeka” (D). De meeste hoofdengeslachten zijn van vreemde smetten niet vrij gebleven. Het is mij niet mogelijk één hoofdengeslacht aan te wijzen, dat niet op een of andere wijze hooger of lager bloed in zich heeft opgenomen. Daarom is het niet onmogelijk, dat de Wadjo'sche "Aroe's" allen meer of minder aan de ,,ana'-matola” verwant zijn geraakt - hetgeen in Bone, bijvoorbeeld, bepaald het geval is - en dat zoo de groep der „Anakaroeng" in beteekenis is verwaterd en aldus een plaats bij de tusschenstanden heeft gekregen. Ook de C-groepen blijken bij de tusschenstanden te zijn ingelijfd. Ik geloof echter, dat de „Taoedetjeng", welke Boegineesche benaming geheel overeenkomt met het Makassaarsche „Toe-badji' " in Gowa (B I), de groep der welgestelde vrijen is, zonder dat hier nu van bloedmenging met hoogere standen sprake behoeft te zijn. Dat sommige van deze welgestelden pretendeeren, ten rechte of ten onrechte, vorstenbloed in de aderen te hebben, is mij zoowel uit Gowa als uit Bone bekend. De beteekenis der „Taoe-tongĕng-karadja” zal van die der „Taoe-detjeng” weinig verschillen. Duidelijk is mij de naam niet: „Taoe-tongěng” kan als synoniem worden beschouwd met ,Taoe-detjeng”; wellicht is het woord „karadja” samengesteld uit „radja” met het praefix „ka” en beteekent het ,groot” of ,,voornaam”.

Ten aanzien van Mandar laten de aanteekeningen van Mallinckrodt ons in het onzekere. Ik wees reeds op de tusschenstanden, die niet den afstand tusschen de vorstentelgen van zuiver bloed naar de eigenlijke vrijen overbruggen, doch ontstaan zijn uit menging van de groep der zuivere vorstentelgen (A I en A II) met de hoofdengeslachten. Nu zijn deze hoofdengeslachten (B I) bij de vrijen (,,Taoemaradeka”, groep B) ondergebracht. Mallinckrodt's aanteekeninge1 over de politieke structuur van Mandar geven mij evenwel de overtuiging, dat dit ten onrechte is geschied. De „regentenadel” in Mandar is in wezen hetzelfde als de hoofdenadel in de andere streken van Zuid-Celebes. Ook in Mandar heeft deze groep een eigen plaats, bovendien, gelet op de tusschenstanden als gevolg van menging met de vorstentelgen van zuivere bloede, een belangrijke en belangwekkende plaats.

Nog een ander punt valt nader te bezien. Uit alle drie schema's blijkt, dat niet alle mengingsmogelijkheden het tot tusschenstand 
hebben kunnen brengen. Zoo missen wij in Mandar een naam voor iemand, wiens vader tot de "Aradjang” (A I) hoort en wiens moeder een "taoe pea nae” (B I a) of een „taoe pea” (B I b) is. Ook het kind, door een lid van de „Aradjang” (A I) verwekt bij een slavin (C) valt niet in een bepaalden tusschenstand. Slechts een beperkt aantal combinaties levert een tusschenstand. In de namen is in Mandar een zeker onderling verband te zien; zij vormen een afdalende reeks: driekwart-maradia's, halve heeren, kwart-heeren. Wij zijn geneigd te vragen: hoe heet nu een kind uit een combinatie, die geen tusschenstand doet ontstaan ? Voor Mandar geven de aanteekeningen van Mallinckrodt een aanwijzing. Het kind van een „Poewa sasigi" man (A IV $\square$ ) en een ,Taoe pea”-vrouw (B I b O) is een lage „Poewa sasigi”. Men duidt den staat van zulk een kind nog op een bijzondere wijze aan, door te zeggen, clat het, in de songko, het hoofddeksel der hoogergeplaatsten, is gevallen" (,bembe di bakoe-bakoe”). Mallinckrodt teekent hierbij aan: „m.a.w. het heeft zijn hoogeren staat nog juist weten te redden".

Wadjo' bezit een hoogst interessante reeks van tusschenstanden. Van Rhijn omschrijft den in het schema onder A I b voorkomenden stand als den stand der "Ana'-matola” (in ruimen zin), die zich tot die hoogte hebben opgewerkt door bloedmenging van hoogere rangen met lagere. Om immers van ,Taoe-maradeka” tot „Ana'-matola” te stijgen, moeten er minstens vier geslachten verloopen. Trouwt een „maradeka”-meisje (D O) met een „Ana'-matola” (A I $\square$ ) dan zijn haar kinderen "Ana'-tjera-sawi” (A IV a). Trouwt een van haar dochters wederom met een "Ana'-matola”, dan zijn de kinderen uit dit huwelijk „Ana'-radjĕng” (en wel „Ana'-radjĕng-lěbbi”, A III a). Een van de dochters huwt wederom met een „Ana'-matola”. Kinderen uit dit huwelijk zijn „Ana'-sangadji”. Trouwt een der dochters, als vóór haar haar moeder, grootmoeder en overgrootmoeder, een „Ana'matola”, dan zijn haar kinderen „Ana'-matola”; zij hebben den op één na hoogsten rang bereikt. Het aantal leden van dezen hoogsten tusschenstand is uit den aard der zaak bijzonder klein. Het is mogelijk, dat in vroegere dagen het bewuste streven naar stijging in stand niet zelden voorkwam. Het enkel bestaan al van deze unieke reeks van tusschenstanden zou het doen vermoeden. Dat dit streven tegenwoordig bestaat, geloof ik, gezien het feit, dat het aantal der „Ana'motala" in Wadjo', Bone en Soppeng, nauwelijks in de tientallen zal loopen, niet. Vele combinaties vallen buiten deze reeks. De lezer zal geen moeite hebben onmiddellijk een aantal van deze combinaties 
zonder naam, met behulp van het schema, te vinden. Van Rhijn zwijgt er over.

In Gowa bleek mij, dat de ongenoemde combinaties, als het er op aan kwam, ingedeeld werden bij een der bestaande tusschenstanden. Deze geven een veel eenvoudiger beeld te zien dan de tusschenstanden in Wadjo'. In Gowa is de hoogste tusschenstand, die der „Ana'sipoewé” (A II) ontstaan uit de verbintenissen van mannelijke vorstentelgen van zuiver bloed met „Maradeka"-vrouwen. De daaropvolgende groep, die der „Ana'-tjera'”, (A III), is gebaseerd op de verbintenissen tusschen mannelijke telgen uit dezelfde groep met slavinnen, terwijl in de derde tusschenstand, die der „Ana'-karaëng-sala” (A IV), de kinderen uit verbintenissen van de mannelijke telgen uit de hoogere tusschenstanden met "maradeka"-vrouwen en slavinnen zijn ondergebracht. In het schema heb ik bij de „Ana'-sipoewé” aangegeven, welke mengingen in deze groep, naast de ,kern-menging”, zooals ik deze zou willen noemen, worden opgenomen. Bij de „Ana'tjera" " (A III) is de op de tweede plaats genoemde menging (hooge A II $\square-O$ C) mij uitdrukkelijk naast de eerstgenoemde menging vermeld, ofschoon deze als de kern-menging moet worden beschouwd. De drie mengingen in den IVden tusschenstand opgenomen, zijn mij als gelijkwaardig opgegeven. Van een kern-menging is hier, naar het voorkomt, geen sprake. Lagere mengingen worden niet meer als adel beschouwd en zonder nadere aanduiding geacht te zijn opgenomen in den stand der vrijen.

Slechts eenige punten nog vragen de aandacht. In Mallinckrodt's schema wordt in de tusschenstanden geen rekening gehouden met de onderverdeeling van den slavenstand; evenmin geschiedt dit in het schema voor Gowa. In Wadjo', het land met het merkwaardigste en ook meest scrupuleuze stelsel, daarentegen wel. Zie de met A IV b en A IV c aangeduide groepen.

Tenslotte de groep der pandelingen. Deze werd tot dusverre niet genoemd. Zoowel door van Rhijn en Mallinckrodt als door mij in verband met de indeeling in standen, in het schema opgenomen, blijkt nu wel duidelijk, dat voor hen in het schema geen plaats is. Van Rhijn vermeldt uitdrukkelijk, dat zij bij de vrijen behooren. Mallinckrodt is niet duidelijk op dit punt, doch meent hetzelfde. Ik zelf kwam tot dezelfde conclusie als van Rhijn. Wel kwam het voor dat pandelingen tenslotte slaaf werden. Doch hierover nader, wanneer ik den slavenstand afzonderlijk behandel. 


\section{A Adel}

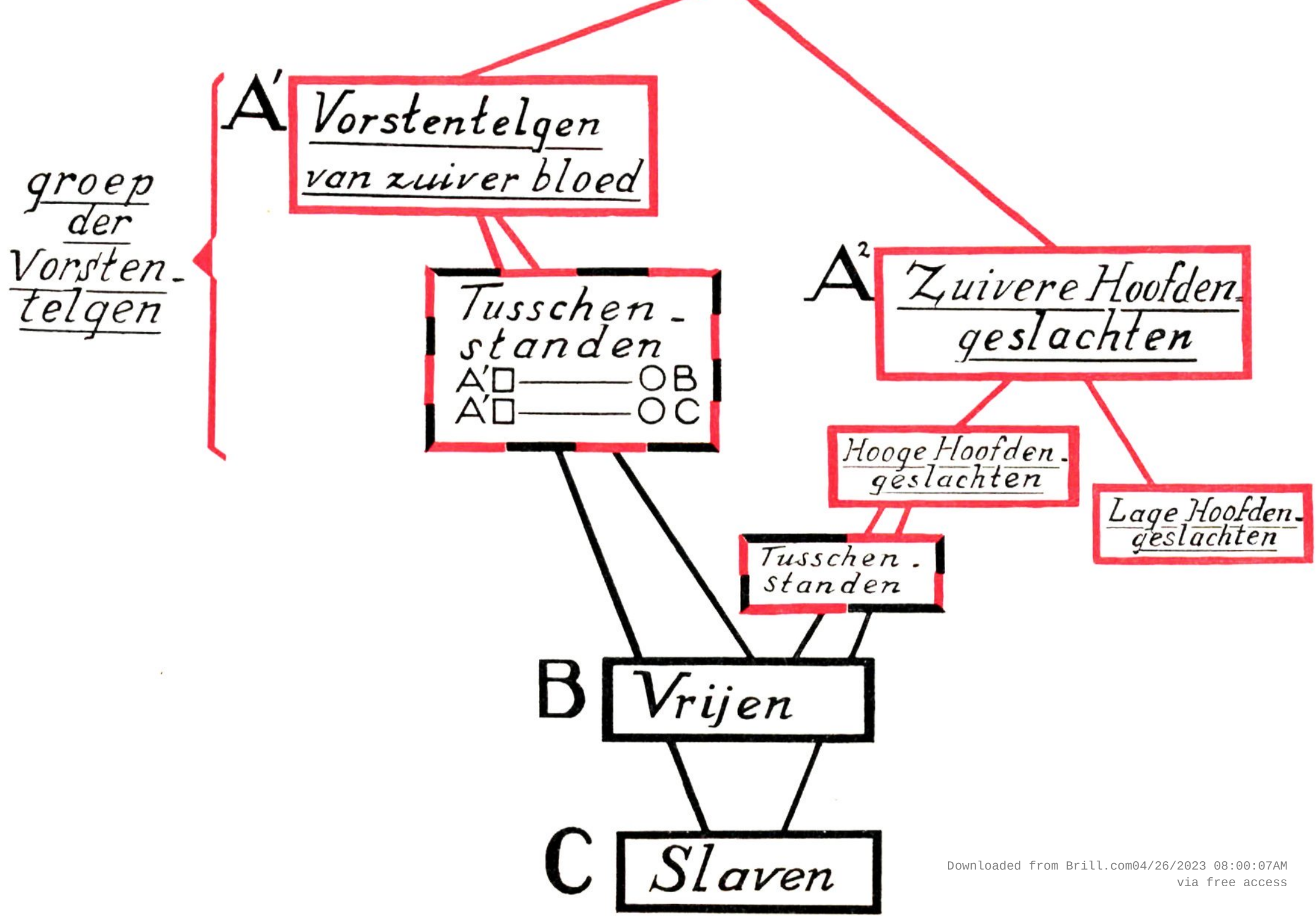


V.

De bespreking van drie schema's betreffende de indeeling in standen op Zuid-Celebes rechtvaardigt de volgende conclusiën :

1. De maatschappij is verdeeld in drie hoofdgroepen en wel: (a) de groep der vorstentelgen van zuiver bloed, (b) de groep der vrijen en (c) de groep der slaven.

2. Menging van (a) met (b) en (c) heeft tusschenstanden doen ontstaan tusschen (a) en (b) en (a) en (c). De afwezigheid van tusschenstanden tusschen (a) en (b) in Mandar dient nog nader te worden aangetoond.

3. Menging van (b) met (c) geeft geen tusschenstanden.

4. De tusschenstanden zijn met (a) in één groep vereenigd.

5. De laagste tusschenstand is hooger dan (b).

6. De hoofdengeslachten vormen geen stand tusschen (a) en (b) in, doch een nevengroep van (a), zij het op lager niveau.

7. Menging van (a) met hoofdengeslachten deed in Mandar tusschenstanden ontstaan.

8. In het systeem der tusschenstanden vindt men de locale verschillen.

9. De mengingen, die geen tusschenstand doen ontstaan, worden ondergebracht bij bestaande tusschenstanden.

10. In het schema is voor de pandelingen geen plaats.

De aandachtige lezer zal bemerkt hebben, dat eenige opvallende eigenschappen der besproken standenstelsels, die te constateeren zijn aan de schema's, stilzwijgend zijn voorbij gegaan. Deze zullen uitvoerig in de volgende hoofdstukken worden behandeld.

De gegevens, tot dusver gerangschikt en beschouwd, laten toe dat wij dit hoofdstuk besluiten met nevenstaande, voor heel Zuid-Celebes geldende schematische voorstelling van de indeeling der standen. 


\section{TWEEDE HOOFDSTUK.}

De standen af zonderlijk.

De vorstentelgen van zuiveren bloede en de tusschenstanden.

I.

De groep der vorstentelgen van zuiveren bloede is in verhouding tot de groote massa der bevolking, de vrijen, zeer klein. Het op het oogenblik ongeveer 300.000 zielen tellende Bone bezit in het geheel geen zuivere Bonesche vorstentelgen meer. Vandaar dan ook dat, toen het Nederlandsch-Indische Gouvernement het in 1931 wenschelijk achtte de vorstelijke waardigheid in Bone te herstellen, de rijksraad van Bone in het land zelf niemand, waardig om den Boneschen troon te bestijgen, kon vinden en zijn keus moest laten vallen op een Gowaschen prins, een prins dus uit het huis, dat door huwelijken, vooral in de vorige eeuw, nauw vermaagschapt was aan het Bonesche. In Gowa is de groep der zuivere vorstentelgen, tegenover een bevolking van het kerngedeelte van het rijk van ongeveer 80.000 zielen, een veertigtal personen sterk, kinderen medegerekend. Het aantal zuivere vorstentelgen in Loewoe', Soppeng, Wadjo', Sidenreng en Bantaëng - waarmede ik de overige voorname rijken genoemd heb - bedraagt slechts enkele tientallen.

Al deze vorstenhuizen pretendeeren af te stammen van een stamvader of stammoeder van hemelschen oorsprong. Matthes heeft in zijn Makassaarsche Chrestomathie ${ }^{\mathbf{1}}$ ) een handschrift gepubliceerd, dat betrekking heeft op de oudste geschiedenis van Gowa, Tallo en eenige andere rijken op Zuid-Celebes. Toen reeds was het bijna de eenige bron, waaruit men eenige kennis van de oude geschiedenis van Gowa en naburige rijken, kon putten ${ }^{2}$ ). Ik behoef niet te zeggen, dat het er niet beter op is geworden. De leden van het voormalig vorstengeslacht zijn over het algemeen bijzonder slecht op de hoogte van mythen en legenden hun eigen geslacht betreffende. Bij het gewone volk vindt men hoogst zelden personen, die van deze zaken werkelijk iets weten, dat eenigszins de moeite van het opteekenen loont. In de huizen van de gewone lieden gaan meer de locale vertelsels rond.

Een der naaste verwanten van den laatsten vorst van Gowa had,

1) Blz. 146 e.v. Makassaarsche Chrestomathie door Dr. B. F. Matthes, 's-Gravenhage, 1883 .

2) Blz. 6 van de Aanteekeningen bij de Mak. Chrest. 
naar ook in zijn onmiddellijke omgeving aangenomen werd, althans tijdens de jaren, dat ik in Gowa woonde, zeer waardevolle handschriften in zijn bezit. Hij zelf ontkende dit echter ten sterkste. Misschien had hij slechte ondervindingen opgedaan bij het uitleenen van manuscripten. Ook Bonesche handschriften, waaronder geslachtslijsten, moest hij, naar men mij in Bone vertelde, tijdens de expeditiejaren in bewaring hebben gekregen. Ook dit ontkende hij. Hoe het ook zij, noch ik, noch iemand anders kreeg kans deze handschriften te zien, laat staan te copieeren. Zoodat, en hier zijn wij weer bij ons uitgangspunt terug, het in Matthes' Makassaarsche Chrestomathie gepubliceerde handschrift de beste bron blijft. Van dit manuscript, waarvan ouderdom en schrijver onbekend zijn, is het begin zeer beknopt. De inhoud van dit gedeelte vooral is voor ons van belang. Ik geef deze hieronder zoo getrouw mogelijk weer.

„Dit is de oude geschiedenis van de Gowareezen. Moge ik geen gezwollen buik krijgen, moge ik niet met mijn geslacht verstrooid raken tengevolge van het in volgorde opnoemen der oude Karaëngs. Moge ik met mijn geslacht verstuiven, moge ik over mijn geheele lichaam builen krijgen, moge ik tot gesmolten goud worden, moge ik als de schakels van een halssnoer uiteenvallen (indien ik een fout mak bij dat opnoemen). Er wordt toch voor gevreesd, dat zij vergeten worden door hun kinderen en kleinkinderen, door hun nakomelingen; want als zij niet gekend worden, dan zal het aan twee kanten slecht zijn : èn wij zullen ons te hoog achten, èn de buitenlanders zullen ons nuttelooze of geringe nietswaardigen noemen.

De „Toe-ma'noeroeng” (lett. de ,nedergedaalde mensch”) en $\mathrm{Ka}$ raëng Bayo huwden met elkander. De moeder van „Toe-masalanggabaraya” (lett. „,de scheef geschouderde”) was het, die door de voorouders ,Toe-ma'noeroeng” werd genoemd, omdat haar herkomst onbekend was en haar verscheiden een zwevend verdwijnen werd geheeten.

Zij was het, die door Karaëng Bayo tot vrouw werd gemaakt en ook het land van Karaëng Bayo was onbekend; naar verluidt had hij een broeder „Lakipadada”, dezelfde die de ,Soedang” (een van de voornaamste rijkssieraden van Gowa, een zwaard,) heeft bezeten. Karaëng Bayo huwde dus de „Toe-ma'noeroeng” en het kind „I-masalangga-baraya" werd na een driejarige zwangerschap geboren. Het kon al dadelijk loopen en praten, doch zijn ouders, de slaven en het volk waren bekommerd, daar het kind misvormd was. Want het werd „,Toe-masalangga-baraya” geheeten, omdat de eene schouder hoog en 
de andere laag was. Zijn eene oor was plat en het andere knobbelig, het voorste gedeelte zijner voeten stak niet verder van voren uit, dan zijn hielen van achteren, zijn navel was zoo groot als een „,bakoekaraëng" (een mandje met rijst gevuld, waarin bij feesten de kaarsen worden gestoken).

Toen sprak zijn vorstelijke moeder : ,Wat staat ons te doen nu mijn kind zoo mismaakt is? Want zijn schouders zijn scheef, zijn ooren zijn als een vooroverhellende berg; zelfs hooren zij het, zoo iemand op Java zijn haar laat knippen. Een doode kakkerlak op Salajar kan hij ruiken, een ,,poeteng” (een soort van duif), die zich te Bantaëng bevindt, zien; zijn voeten zijn zoo gelijk als de schalen van een balans; zijn navel is als een krachtige bron. Maar zijn handen zijn bijzonder vaardig. Al wie dezen vorst zijn hulde zal brengen, diens welvaart (lett. leven en bedrijvigheid) zal groot (lett. uitgestrekt) zijn; al wie dezen vorst hulde zal brengen, zal vele ,tai's" (een gewicht) goud deelachtig worden; al wie hem hulde zal brengen, zal vele menschen tot zijn beschikking krijgen."

Toen haar kind groot geworden was, deelde haar halsketen zich in tweeën. Eèn helft bleef achter bij haar kind. De helft, die bij het kind bleef, werd geheeten „I-Tanisamanga” (een van de voornaamste rijkssieraden van Gowa).

De ouden noemen het verscheiden van "Toe-masalangga-baraya” een zwevend verdwijnen bij de heuvels ten Noorden van Djonggowa, dat gepaard ging met donder en bliksem en regen met zonneschijn. Wie „Toe-masalangga-baraya's” echtgenoote was, weet men niet. Zijn kinderen, behalve zijn opvolger, zijn onbekend. Ook weet men, noch van zijn oorlogen, noch van den duur zijner regeering, iets af, want te dien tijde waren er nog geen ,lontara's”).

Karaëng Bayo bezat een „sonri” (een soort van zwaard) genaamd „Tanribalanga” (een van de rijkssieraden van Gowa).

„Toe-masalangga-baraya” gewon „I-Poewang-lowe-lembang”, „I-Poewang-lowe-lembang” gewon „Toe-niijata-banri”, „Toe-niijata-banri” gewon „Karampang-ri-Gowa”, „Karampang-ri-Gowa” gewoon „,Toe-natangka-lopi”.”

Tot zoover dit handschrift.

Matthes moet voor zijn „Boegineesche en Makassaarsche legen-

1) „Lontara” = blad van den ,lontar”- of „tala”-boom (Borassus flabelliformis L.) vroeger gebruikt om met een stift op te schrijven, v. d. geschrift dat op dusdanige wijze tot stand is gekomen; tegenwoordig ook: oud of pseudo-oud papieren manuscript. 
den" ${ }^{1}$ ), nog uit andere handschriften gegevens hebben geput. Zoo wordt daar gesproken van een vrouwelijk wezen, dat in de nabijheid van een „djombe-djombe”-boom (,Mangifera indica”) uit den hemel op aarde nedergedaald zou zijn met een gouden halsketen versierd en een soort van bord in de handen. Tegelijkertijd vertoonde zich naast haar een groote woning van vijf vakken in de lengte. Karaëng Bayo komt dan later, vergezeld van zijn broeder Lakipadada, uit het Oosten.

Deze manuscripten hebben vermoedelijk, met nog andere tezamen, ook ten grondslag gelegen aan het aan „Makassar” (bedoeld is Gowa) gewijde gedeelte in de „Beknopte Geschiedenis van het Makassaarsche Celebes en Onderhoorigheden", van de hand van Roelof Blok, van 1756-1760 Gouverneur en Directeur ter Zuidkust van Celebes. Eerst in 1848 werd dit opstel, bedoeld als memorie voor Bloks opvolger, gepubliceerd ${ }^{2}$ ). Daargelaten, dat het alle eigennamen gruwelijk verminkt, maakt het een hoogst betrouwbaren indruk. Voor wat de oudste tijden en gebeurtenissen betreft, zoo wordt uitdrukkelijk vooraf gezegd, heeft de schrijver ,,de Bonische en Makassaarsche manuscripten gevolgd." Hoewel in hoofdzaken overeenkomende met eerstgenoemde, door Matthes gepubliceerde kroniek, bevat dit stuk toch eenige vermeldenswaardige afwijkingen of liever aanvullingen, die niet den indruk maken uit het brein van Blok te zijn gesproten. Deze nu schrijft, dat het Makassaarsche manuscript der opvolging hunner koningen spreekt van vier regeerders vóór de komst van de „Toe ma'noeroeng”. De eerste is dan „Batara Goeroe” geweest, de tweede zijn broeder, die slechts onder den bijnaam ,de door Talali vermoorde” nog bekend is, de derde „Ratoe Sapoe Marantaya” en de vierde „Karaëng Katangka”. Na het overlijden van dezen laatsten daalde de „Toe-ma'noeroeng” neer. Zij werd door de Makassaren (bedoeld is Gowareezen) tot vorstin uitgeroepen en huwde met Ka. raëng Bayo, den „Koning van Bonthain, (Bantaëng), die op het gerucht, dat te Goa zulk eene schoone vrouw uit den hemel gedaald was, zich derwaarts begaf, om met haar eene verbindtenis te sluiten." Deze Karaëng Bayo is dan, volgens de bronnen van Blok, tezamen met zijn gemalin en zijn broeder, Lakipadada, niet gestorven, doch verdwenen. Over de vier vorsten, die regeerden vóór de nederdaling van de "Toe-ma'noeroeng”, schijnen de kronieken overigens te zwijgen. Omtrent de regeerders, die op de „Toe-ma'noeroeng” volgden

1) Bijdragen tot de Land-, Taal- en Volkenk. v. Ned.-Ind., 4, X, pag. 439-441.

2) Tijdschrift voor Ned.-Indië. Jaargang $X$. 
vermeldt Blok nog, dat „Toe-natangka-lopi” de eerste sterfelijke vorst was. Zijn voorgangers zijn niet gestorven, doch alle verdwenen.

Van de eerste zeven vorsten van Bone worden eenige bijzonderheden vermeld in een kroniek, die in 1859, bij het binnenrukken van de Nederlandsche troepen in Pasempe, in de woning van de voortvluchtige vorstin is gevonden. Bakkers, de latere Gouverneur van Celebes en Onderhoorigheden, die in 1865 ter vervulling van een politieke zending geruimen tijd aan het hof van den vorst van Bone vertoefde, vertaalde deze en maakte daarbij gebruik van toelichtingen, hem verstrekt door aan dat hof verblijvende personen ${ }^{1}$ ). Het eerste gedeelte laat ik hieronder eenigszins verkort volgen ${ }^{2}$ ).

„Lang geleden, nadat een hevig en langdurig onweder had gewoed, zag men buiten op het veld een man staan, die geheel in het wit gekleed was. De tezamen gestroomde menigte meende met een „Toemanoeroeng", een uit den hemel gedaalde, te doen te hebben. De menschen uit den omtrek begaven zich tot hem en verzochten hem eerbiedig hun vorst te willen worden. De man, dien men van den hemel gedaald waande, zeide evenwel, dat hij geen vorst kon zijn, omdat hij een slaaf was; doch indien zij een vorst wilden hebben, wist hij wel iemand, dien zij daartoe kiezen konden. Daarop zeide de toegestroomde menigte: „Hoe kunnen wij iemand, dien wij niet zien noch kennen tot onzen vorst kiezen ?” De gewaande ,Toe-manoeroeng” zeide: „Indien gij werkelijk een vorst hebben wilt, dan zal ik $\mathrm{U}$ hem toonen." De verzamelde menigte zeide: „Gaarne willen wij een vorst hebben, en daar gij toch zooveel medelijden met ons hebt getoond, geleid ons dan naar uw vorst.” De gewaande „Toe-manoeroeng" voldeed aan haar verzoek, en geleidde de verzamelde menigte naar een plaats genaamd Matadjĕng. Op den weg derwaarts begon het onweder met vernieuwde hevigheid, maar aangespoord door haar geleider dacht de menigte aan geen terugkeeren. Te Matadjĕng gekomen zag men den persoon, die door den in het wit gekleeden man bedoeld en de ware „Toe-manoeroeng” was, op een vlakken vierkanten steen zitten. $Z$ ijn kleeding was van gele stof en hij had drie zijner volgelingen bij zich; een van dezen had een geel zonnescherm in de hand, één waaide den „Toe-manoereeng” met een waaier, en een droeg zijn sirihdoos. Toen de in het wit gekleede persoon bij den ,,Toe-manoeroeng” kwam zeide deze: „Zijt gij daar

1) J. A. Bakkers. „Het leenvorstendom Boni”. Tijdschrift voor Indische Taal-, Land- en Volkënkunde, deel XV (1866), blz. 168, e.v.

2) Spelling van de inheemsche termen van Bakkers. 
reeds Tomatowa ?" waarop de Tomatowa antwoordde: „Ja heer!' De vergaderde menigte wist nu, dat de persoon, dien zij op het veld had gevonden en als haar vorst had willen hebben, slechts een "Tomatowa” was. De „Tomatowa” zeide daarop tot de menigte: „Deze is mijn heer", waarop de menigte zich tot den „Toe-manoeroeng” begaf, en hem nederig verzocht haar vorst te willen wôrden. Dit aanvaardde de „Toe-manoeroeng”, waarop hij naar Bone werd gebracht, alwaar men voor hem een afzonderlijke woning bouwde, die hem tot verblijf moest dienen.

De eigennaam van den „Toe-manoeroeng” is nimmer bekend geweest. Zijn bijnamen kreeg hij vanwege zijn eigenschappen en daden. Zoo ontving hij den naam „Mataselompowé”, omdat hij met een enkelen oogopslag het aantal eener groote menigte bijeenvergaderde menschen wist op te geven; terwijl hem de naam "Mapololeteeng" werd gegeven, omdat hij allerlei instellingen heeft ingevoerd.

Hij was het, die de eerste regeling in het bestuur bracht, die het gerechtelijk onderzoek instelde en die verschillende ambtenaren en „pabitjara's” benoemde. Hij ook was het, die het eerst de ,Woromporong" ") bezat.

Hij is gehuwd geweest met de „Toe-manoeroeng” van Toro, bij wie hij vijf kinderen verwekte, waarvan een den naam van Pantara Wanoewa droeg. Na een 36-jarige regeering droeg hij de regeering over aan zijn zoon Laoemasĕ en verdween daarop met zijn echtgenoote, terwijl het onweerde, de gele pajong en de sirihdoos medenemende.

Laoemasě droeg naast den naam van „Tomoelaié paré” ook dien van ,den smid”. Men prees hem wegens zijn goed geheugen, zijn waakzaamheid en zijn bezadigdheid. Laoemasě huwde zijn zuster Pantara Wanoewa uit aan Lapatikkě Aroe Palakka. In Bone was niemand, die hem in lichaamskracht, lengte en grootte overtrof. Hij had geen wettig kind, dat hij tot zijn opvolger kon benoemen, maar alleen twee onwettige zoons, genaamd Tosoewalé en Tosalawakkĕ, wier moeder een gewone vrouw uit lageren stand was.

Toen hij hoorde, dat zijn zuster, die te Palakka gehuwd was, in gezegende omstandigheden verkeerde, liet hij daarnaar onderzoek doen, en eerst toen dat bericht bevestigd werd, was hij gerust. Toen hij later vernam, dat de bevalling zijner zuster nabij was, liet hij

1) Noot van Bakkers. De "Woromporong" is een vlag, behoorende tot de cerste rijkssieraden van Boni. Thans bestaat zij niet meer. Zij werd Woromporong genoemd, naar de 7 sterren, die in het doek geschilderd waren. 
Tosoewalé en Tosalawakkě bij zich komen en zeide tot hen: „Ga spoedig naar Palakka, want ik heb gehoord, dat mijn zuster begint te gevoelen, dat zij spoedlig zal bevallen, en als zij bevallen is, dan moet gij het kind terstond, al was het in een mand, hier brengen; eerst hier zal men het reinigen en van de nageboorte ontdoen. Tosoewalé en Tosalawakkě begaven zich daarop naar Palakka, en juist toen zij daar waren aangekomen en zich hadden neergezet, beviel de vrouw van Aroe Palakka van een zoon, wiens haren stijf stonden. Tosoewalé begaf zich daarop spoedig naar het kind, wikkelde het in een kleed en bracht het zoo naar Bone.

Toen dit gebeurde was Aroe Palakka niet te huis. Eerst in Boni werd het kind gereinigd en van de nageboorte ontdaan. De zuster van den vorst, genaamd Samatappĕ (Wetan-rironrong) werd met de bewaking van het kind belast. In denzelfden nacht nog werd aan al de Bonieren door het geheele land bekend gemaakt, dat zij zich den volgenden morgen vroeg in krijgsgewaad en gewapend voor het huis van den vorst moesten verzamelen. Nauwelijks was dan ook de morgen aangebroken, of de Bonieren waren in krijgsgewaad en gewapend bijeen; de „Woromporong” werd ontrold, waarop zich de vorst van Bone naar beneden in een feestloods begaf en tot de vergaderde Bonieren zeide : ,Ik heb $U$ laten verzamelen, omdat ik U zeggen wil, dat ik mijn zoon den naam heb gegeven van Lasaliwaro, en den titel van Karampeloewa, en dat ik thans ten behoeve van dezen mijnen zoon afstand doe van den troon, aan wien ik ook al de bevelen van den vorst Tomaladjangé (die op geheimzinnige wijze verdwenen is) overgeef. De Bonieren beantwoordden deze toespraak met een gezamenlijk ,Ja," en begonnen daarop tandakkende den eed van trouw te zweren. De bewaker der rijkssieraden werd nu dadelijk naar boven gezonden om het ritueel te regelen, waarna de vorst Karampeloewa werd gekroond (rilanti), welk feest zeven dagen en zeven nachten duurde. Nadat alzoo zeven dagen en zeven nachten ter eere van den jongen vorst was feest gevierd, werd zijn navel gereinigd. Toen dit was geschied, betrok de oude vorst een andere woning en werd Karampeloema voortaan Aroempone genaamd, terwijl zijn tante Samatappě als zijn moeder beschouwd werd. Als nu de oude vorst eens wilde uitgaan, liet hij dit eerst aan den jongen vorst weten, waarop dan de persoon, die het kind droeg de bevelen gaf tot het maken der toebereidselen daarvoor. Zeventien jaren, nadat Laoemasě afstand van den troon gedaan had, werd hij aangetast door een zware ziekte, aan welker gevolgen hij kwam te overlijden. Na zijn dood 
werd hij genaamd „Tomoelaié pare”, welke naam beteekent: „Hij, die het eerst werd ter aarde besteld."

Het Soppengsche vorstengeslacht zegt af te stammen van een te Sekanjili, in Oostelijk Soppeng, nedergedaalden hemeling, genaamd La Temamala. Evenals de Bonesche Toe-ma'noeroeng wordt ook hij door de bevolking, na het sluiten van een soort overeenkomst, tot vorst uitgeroepen. Matthes verhaalt in zijn reeds genoemd opstel over Boegineesche en Makassaarsche legenden, - en laat, zijn gewoonte getrouw, het noemen van bron of zegsman achterwege - dat deze vorst onmiddellijk na zijn uitroeping den wensch te kennen geeft, dat een tweede vorst zal worden aangesteld. Deze zou dan de belangen van Oost-Soppeng ter harte mogen nemen, terwijl hij zelf over Westelijk Soppeng zou regeeren. Die vorst, gewoonlijk genaamd „Manoeroengé ri-Liboerĕng, d.i. ,„de te Liboerĕng nedergedaalde”, of ook wel „Manoeroengé ri-gowariyé”, d.i. ,de in het vertrek nedergedaalde”, bevond zich te Liboerěng, waar hij in een vertrek, bij het breken van een ,baloeboe” of antieke pot van Chineesch porcelein of aardewerk, te voorschijn was gekomen. Dezen hemeling wist men insgelijks te bewegen als vorst op te treden. Beiden zijn in het huwelijk getreden met hemelingen.

In de scheppingsmythe uit het La-Galigo-epos ${ }^{1}$ ), is Batara-Goeroe, de oudste zoon van Patoto', den Schepper, de eerste vorst van Loewoe' en tevens de eerste vorst op de te voren ledige aarde. De achterkleinzoon van Batara-Goeroe, Salinroeng-langi of Lětté'-parěppa geheeten, verlaat de aarde, wanneer hij verneemt, dat de gemeenschap tusschen aarde en hemel en aarde en onderwereld verbroken zal worden. Naar mij uit een brief van mijn vriend, den controleur Mr. J. Gerritsen, die ruim drie jaren in Loewoe' heeft gediend, blijkt, pretendeert het Loewoe'sche vorstengeslacht tegenwoordig rechtstreeks van BataraGoeroe af te stammen. Ik moet aannemen, dat dit in den tijd van Matthes, die in Loewoe'sche zaken over het algemeen goed geinformeerd was, niet het geval was. In zijn „Boegineesche en Makassaarsche legenden" neemt hij ${ }^{2}$ ) voor Loewoe' en elders op Zuid-Celebes een tijdperk zonder vorstelijk bestuur aan, namelijk dat, gelegen tusschen het vertrek van den godenzoon Lětté'-parěppa en de nederdaling

1) Gepubliceerd in de Boegineesche Chrestomathie van Dr. B. F. Matthes, 1864, 2de uitg., A'dam, 1883.

2) Blz. 434. 
van den eigenlijken stamvader van het Loewoe'sche vorstengeslacht: Simpoeroesiya. Dit standpunt laat ik voor Dr. Matthes' rekening, omdat, naar mijn meening, de scheppingsmythe zóó geheel anders gewaardeerd dient te worden, dan de opsomming van de Loewoe'sche vorsten, dat een op historische wijze doen volgen van de reeks van godenzonen van Batara-Goeroe tot en met Lětté'-parěppa, eerst door een vorstenloos tijdperk en daarna door de rij van Loewoe'sche vorsten, van Simpoeroesiya tot de huidige vorstin, zonder zin is. Het eenige, wat ons voor het oogenblik belang kan inboezemen, is de volgende mededeeling van Matthes, die naar alle waarschijnlijkheid gegrond is op den inhoud van een manuscript: namelijk dat men in Loewoe' een vorst meent gevonden te hebben, die uit den hemel op de aarde is nedergedaald en den naam draagt van Simpoeroesiya.

„Deze trad in den echt met Patiyang-djala; en uit dit huwelijk werd geboren Anakadji.

Als Anakadji den mannelijken leeftijd bereikt had, huwde hij met zekere We-Tappatjina, de dochter van Sallama-lama, een vorst van Mantjapai', die insgelijks van hemelsche afkomst was. Bij dit Mantjapai' - ik citeer Matthes - denkt men onwillekeurig aan het land, dat op Java bekend stond onder den naam van Modjopait. Echter had men volgens den Inlander ook een Mantjapai' in Bone, dicht bij Patiro, en een Mantjapai' in Wadjo', tusschen Pariya en de Tanasitolo.

Nadat het huwelijk tusschen Anakadji en We-Tappatjina voltrokken was, keerde het jeugdig paar naar Loewoe' terug, en kreeg WeTappatjina bij haar vertrek van haar moeder één pakje uitstekende doepa of wierook, één potje welriekende olie en één kluwen geel geverfde zijde.

Als We-Tappatjina in Loewoe' bevallen was van eene dochter, met name We-Matěnga-empong, en het kind op zekeren dag erg huilde, zong de grootmoeder van vaderszijde een lied, waarin spottenderwijze gezinspeeld werd op dit geschenk van We-Tappatjina's moeder.

We-Tappatjina achtte zich hierdoor beleedigd. Zij brandde onmiddellijk van de geurige doepa, en nadat zij den zijden draad uit elkander getrokken, en met olie besmeerd had, begaf zij zich daarover, als over een brug, naar Mantjapai'.

Toen nu haar man haar overal zocht, vernam hij van zijn moeder, dat de zoo teer beminde echtgenoote naar Mantjapai' de wijk genomen had.

Anakadji spoedde zich derwaarts, en wist haar na veel moeite te 
bewegen, dat zij met hem naar Loewoe' terugkeerde. Bij deze gelegenheid werd het jeugdig paar met geschenken van allerlei aard, vooral in landerijen bestaande, als overladen.

Nauwelijks had de dochter van Anakadji en We-Tappatjina, met name We-Matěnga-empong, den huwbaren leeftijd bereikt, of zij trad in den echt met zekeren Poentjangkoeli, een bewoner der Onderwereld. Uit dat huwelijk werden twee kinderen geboren, een jongen en een meisje. De eerste bekwam den naam van La-Malala, de tweede van Dalaiya. Toen die Dalaiya door een boozen geest toegesproken werd, begreep de vader, dat het zaak was, haar onmiddellijk naar de Onderwereld te laten verhuizen. La-Malala, dit vernemende, wilde zijn zusje gaarne derwaarts volgen, en verzocht daarom voortdurend al dreinende, om naar de rivier te mogen gaan, ten einde daar een bad te nemen. Doch de eigenlijke bedoeling was slechts, om zich daar naar de Onderwereld te laten afzakken. De moeder, dit begrijpende, stelde hem te huis dagelijks in de gelegenheid, om een bad te nemen.

Eindelijk gaf zij aan het verlangen van haar zoon toe. En nu daalde hij met toestemming des vaders in de Onderwereld neder; doch men liet hem, na verloop van 9 dagen in Loewoe' wederkeeren."

Gerritsen geeft evenwel in 1932 de volgende lezing. Aan alle leven op aarde, aanvangende met Batara Goeroe's nederdaling uit den hemel, wordt door een zondvloed een einde gemaakt. Toen de aarde weer bewoonbaar was daalde een vorst uit den hemel neder, die den naam droeg van Mapanoe-oelawangi. Hij huwde met Simpoeroesiang. die uit de Onderwereld kwam en een dochter was van Saweri-gading. die weer een kleinzoon was van Batara Goeroe.

II.

In de groote rijken op Zuid-Celebes zijn de hoogste ambten en waardigheden in beginsel weggelegd voor de hoogste groep. Vorst van Loewoe' kan slechts hij of zij worden, die van het zuiverste Loewoe'sche vorstenbloed is; vorst van Bone kan slechts hij of zij worden, die van het zuiverste Bonesche vorstenbloed is en slechts hij, die van het zuiverste Gowasche vorstenbloed is, kan den Gowaschen troon bestijgen.

Doch niet alleen voor het bekleeden van de vorstelijke waardigheid is het zuiverste bloed vereischte. In Gowa was vóór 1906 de hoogste waardigheidsbekleeder de ,Toemailalang”, ,de man, die binnen is”, de "geheimraad" zou men kunnen zeggen, eigenlijk, zoo men naar zijn bevoegdheden zou willen oordeelen, de ,rijksbestuurder”. Men 
kende den ,Toemailalang Matowa”, den „ouden Toemailalang” en den „Toemailalang Malolo”, den ,,jongen Toemailalang”. De eerste was de rijksbestuurder, de tweede was meer de opperceremoniemeester ten paleize van den vorst. Vroeger had men in Gowa een nog hooger ambt gekend, namelijk dat van „Pabitjara-boetta”, „spreker des lands”. Deze functie, oorspronkelijk ingesteld in verband met de jeugd van den vorst, veranderde in den loop der tijden van karakter. Toen Gowa en Tallo nog hecht verbonden waren, was de oudste der vorsten steeds „Pabitjara-boetta” van den jongsten, ook al had deze de meerderjarigheid bereikt.

Op de beide Toemailalangs volgde in macht en aanzien de „Anronggoeroe lompona Toemakadjannanganga" ${ }^{1}$ ), de opperbevelhebber in oorlogstijd en in vredestijd de uitvoerder van 's vorsten bevelen, daar waar gewelddadig optreden werd vereischt. Een der voornaamste hoogwaardigheidsbekleeders was voorts de „Anronggoeroe lompona Toebontowalaka”, ,het opperhoofd van de menschen van Bontowala'." Tenslotte rest ons nog te noemen den "Sabannara'”, den havenmeester, wien in Gowa behalve de inning van haven- en ankerage-gelden, ook het beheer over 's vorsten inkomsten was opgedragen.

Al deze hooge dignitarissen nu dienden tot den hoogsten stand, in Gowa dus tot de ,ana'-tino” te behooren.

Kende Gowa een „Toemailalang Matowa” en een „Toemailalang Malolo”, Bone had zijn „Tomarilalěng”. Tweemalen in Bone's geschiedenis heeft de Tomarilalěng, of Rijksbestuurder, een hoogwaardigheidsbekleeder naast zich gehad, die in rang en aanzien niet voor hem onderdeed, daar Bone tweemalen een „Makkědatana” heeft gehad, d.w.z. een landsgroote, wiens positie in zekeren zin overeenkwam met die van regent. Wij ontmoeten hier de Gowasche „Pabitjaraboetta”, wiens Boegineesche naam „Makkědatana” dan ook eveneens „,spreker des lands” beteekent. Een zeer voornaam landsgroote was immer de „Poenggawa”, die in oorlogstijd de opperbevelhebber van 's vorsten leger was en bij belangrijke aangelegenheden zitting had, indien de vorst met den rijksraad confereerde. Ook voor Bone geldt het beginsel, dat deze hoogste landsgrooten gekozen worden uit de groep der vorstentelgen van het zuiverste bloed.

Dat dit beginsel niet altijd zuiver gehandhaafd kon worden, behoef ik nauwelijks te zeggen. Niet alleen dat het zeer wel denkbaar is, dat er in de hoogste groep niemand was, die „Toemailalang” of „Tomari-

1) Zie ook Hoofdstuk IV, pag. 530 . 
lalěng" kon worden, - ik denk aan minderjarigheid, lichamelijke ongeschiktheid, algeheele ontstentenis van mannelijke vorstentelgen van het zuiverste bloed - , doch het persoonlijk element mag nimmer uitgeschakeld worden. Als het er op aan komt, kòn een vorst van Bone of Gowa een Tomarilalĕng of Toemailalang van zuiveren bloede zeer wel vervangen door een gunsteling van iets minder zuiver bloed, want hun macht was groot. Toch zal een hoogwaardigheidsbekleeder als de Toemailalang of de Poenggawa nimmer gekozen worden uit een groep, die lager is dan de hoogste tusschenstand.

Noch de hoogste groep in Bone, noch die in Gowa heeft zich door de tijden heen ongerept weten te bewaren. Niet alle smetten of smetjes zijn na te speuren, doch zeker is dat de XXIste vorst van Bone, Lama'pasossong Djaliloeddin Abdulradjab Datoe Baringang (17491775), een zoon was van den XVden vorst, Lapataoe (1696-1714) en een vrouw van mindere geboorte ${ }^{1}$ ), terwijl in 1653 Malombasang Hasanoeddin zijn vader Moehammad Said op den Gowaschen troon opvolgde, hoewel zijn moeder een vrouw van geringe afkomst was. Deze Hasanoeddin was de XVde vorst van Gowa. De XVIde vorst, Mappasomba was zijn halfbroeder, evenals de XVIIde, Mappasossong Karaëng Biseï; diens zoon, Mappadoelang of Abdoeldjalil werd als XVIIIde vorst van Gowa door den rijksraad afgezet en opgevolgd door den vorst van Tallo, Mappaoerangi. Mappaoerangi was van het zuiverste bloed en stamde lijnrecht af van den Vden vorst van Gowa Toe-natangka-lopi, die, volgens de overlevering, zijn rijk in twee deelen splitste en het eene deel aan zijn zoon Batara Gowa, den VIden vorst van Gowa naliet, en het andere aan zijn zoon Karaëng-Loweri-Sero, die aldus de eerste vorst van Tallo werd. Tegenwoordig nog wordt aangenomen, dat het Gowasche vorstengeslacht van zuiveren bloede is. Het Bonesche vorstenhuis was de laatste eeuwen niet meer zuiver te noemen, daar alle latere vorsten en vorstinnen van den genoemden Lama'pasossong afstamden. Practische beteekenis had zulk een daling van het bloedgehalte voor de indeeling van de standen niet. $\mathrm{Na}$ eenige geslachten was zulk een vlek vergeten en er valt niet aan te twijfelen dat, ook in de oogen der bevolking, de vorst met zijn verwanten van gelijk bloed in Gowa , ana'-tino'" en in Bone ,,ana'matola" blijft.

\section{III.}

Een uitvoerige bespreking van de erfopvolging in de vorstelijke waardigheid is gewenscht, daar men aangaande de successie bij de

1) Zie de geslachtslijst der Bonesche vorsten, blz. 482 e.v.

D1. 90. 
Boegineezen en Makassaren, in het land zelf, zoowel onder de leden der verschillende vorstenhuizen, als onder de bestuursambtenaren, zeer van elkander afwijkende meeningen aantreft. Zoo is het ook bij de auteurs, zoodat het zeer moeilijk is, op dit punt een helder oordeel te vormen. Men verneemt, dat de vorst bij zijn leven zijn opvolger placht aan te wijzen en dat zijn wil wet was, maar ook, dat de rijksraad, waarmede dan bijvoorbeeld in Bone de "Aroepitoe” en in Gowa de „Batesalapang” wordt bedoeld, een opvolger verkoos nà het overlijden en vóór de teraardebestelling van den vorst. In zijn opstel over de rijkssieraden van Loewoe' ${ }^{1}$ ) deelt Prof. C. Spat zelfs mede, dat op grond van de kinderverdeeling tusschen de beide ouders bij de Boegineezen en Makassaren ${ }^{2}$ ) een vorstin opgevolgd wordt door een aan haar en een vorst door een aan hem toebehoorend kind.

Het lijkt mij aanbevelenswaardiger de feiten te laten spreken, dan te vervallen in een bestrijding van al wat tot dusver, vaak verscholen tusschen andere gegevens en bijkomstig behandeld, geschreven is over vorstenkeuze en erfopvolging.

Wenden wij ons daarom tot die gegevens, die licht kunnen verschaffen omtrent de erfopvolging in de toonaangevende Makassaarsche en Boegineesche rijken. Ik stelde zoowel van de Gowasche ${ }^{3}$ ) als van de Bonesche ${ }^{4}$ ) vorsten en vorstinnen lijsten op en gaf daarin zoo nauwkeurig mogelijk aan, in welke verwantschapsverhouding iedere vorst of vorstin tot zijn of haar opvolger of opvolgster stond.

Gowa.

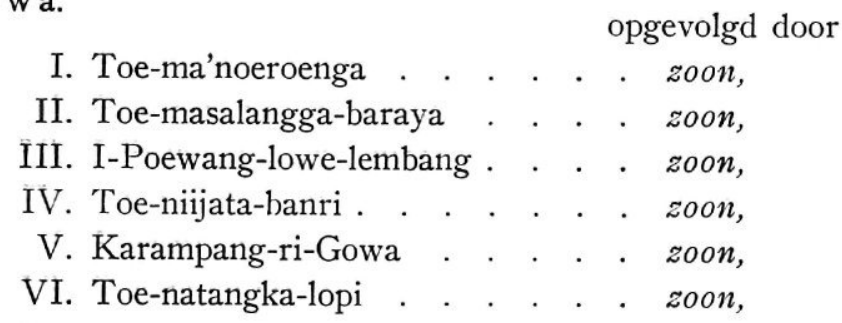

1) „Ned. Indië Oud en Nieuw”, 3. (1918-1919).

2) $\mathrm{Bij}$ scheiding is het eerste kind voor de vrouw, het tweede voor den man, het derde weer voor de vrouw, enzoovoorts.

3) „Beknopte Geschiedenis v. h. Makass. Celebes en Ond.”, Tijdschrift voor Neerl. Indië, jaarg. X (1848), pag. 3 e.v.; - A. Ligtvoet, „Dagboek der vorsten van Gowa en Tello", Bijdragen T. L. en V. van Ned. Indië, IVde volgr., IVde deel (1880), pag. 1 e.v.; - Dr. B. F. Matthes, „Makassaarsche Chrestomathie”, (1883), pag. 146 e.v.; - B. Erkelens, „Geschiedenis van het rijk Gowa", Verh. Bat. Gen. v. K. en W., deel I, 3de.stuk (1897), pag. 81 e.v.

4) J. A. Bakkers, „Het leenvorstendom Boni”, Tijdschrift voor Ind. T. L. en V., XV, (1866), pag. 154 e.v. 
opgevolgd door

VII. Batara Gowa . . . . . . . . zoon,

VIII. Toe-nidjallo-ri-Pasoekki. . . . jongeren broeder,

IX. Toe-maparisi-kalonna. . . . . . zoon,

X. Toe-nipalangga . . . . . . . . broeder,

XI. Toe-nibatta . . . . . . . . . zoon,

XII. Toe-nidjallo . . . . . . . . . zoon,

XIII. Toe-nipassoeloe. . . . . . . . jongeren broeder,

XIV. Soeltan Allahoeddin . . . . . . zoon,

XV. Moehammad Said . . . . . . zoon,

XVI. Malombasang Hasanoeddin . . zoon,

XVII. Mapasomba . . . . . . . . . halfbroeder, zelfde vader,

XVIII. Mapa'osong Karaëng Biseï . . . broeder,

XIX. Mapadoelang of Abdoeldjalil . . kleinzoon, zoon van dochter,

XX. Sapoewali Soeltan Ismail . . . . vorst van Tallo,

XXI. Mapaoerangi Soeltan Siradjoeddin . zoon,

XXII. Manrabiya Soeltan Nadjamoeddin . vader,

XXIII. Mapaoerangi Soeltan Siradjoeddin. kleinzoon, zoon vorst $\mathrm{v}$. Tallo,

XXIV. Malowanggaoe . . . . . . broeder,

XXV. Mapababasa . . . . . . . . . zoon,

XXVI. Oesman of Amas Madina . . . . broeder, (Batara Gowa II)

XXVII. Aroe Mampoe . . . . . . . . broeder van groot-

vader vaderskant,

XXVIII. Soeltan Zainoeddin . . . . . . zoon,

XXIX. Karaëng Mangasa

Regeeringsloosheid.

XXX. Mapatoenroe Karaëng Lembangparang zoon,

XXXI. Laoedanrioe Karaëng Katangka . . zoon van zuster en

XXXII. I-Koemala

$$
\text { neef, }
$$

XXXIII. Malingkaäng Karaëng Katangka . . zoon,

XXXIV. Koelaoe Karaëng Lembangparang,

laatste vorst van Gowa, overleden

in 1906. 
Bone.

Daar de gegevens over het vorstengeslacht van Bone uitgebreider zijn en het beeld, dat de erfopvolging daar biedt, ook minder eenvoudig is, moet de lijst, wil zij de verwantschapsverhouding tusschen iederen vorst of vorstin en zijn of haar opvolger of opvolgster duidelijk voor oogen stellen, anders ingericht zijn dan die van de Gowasche vorsten. Daarom zijn onder den naam van den regeerenden vorst of vorstin, indien hij of zij door een van zijn of haar kinderen wordt opgevolgd, deze kinderen tot en met den opvolger of de opvolgster vermeld. Deze laatste wordt dan met name genoemd. Overigens spreekt, geloof ik, de lijst voor zich zelf.

I. Manoeroenge-ri-Matadjang.

Kinderen: 1. zoon.

2. dochter.

3. zoon, Laoemasě.

II. Laoemasě.

Kinderloos ${ }^{2}$ ).

III. Lasaliwoe Karampeloewa.

(4de kind $[=2$ de zoon $]$ v. h. 4de kind $[=2$ de dochter $]$ van den Isten vorst).

Kinderen: Webanri-gaoe, dochter.

IV. Webanri-gaoe.

Kinderen: 1. dochter.

2. dochter.

3. zoon, Latanri-Soekki.

V. Latanri-Soekki.

Kinderen: 1. dochter.

2. zoon, Lawoelio Boteé.

VI. Lawoelio Boteë.

Kinderen: 1. dochter.

2. zoon, Laitja (VIIIste vorst).

3. zoon, Latanri Rawe (VIIde vorst).

VII. Latanri Rawe. (Vader heeft afstand gedaan ten behoeve van -.)

Kinderen: 2 zoons vroeg gestorven.

1) (M.) beteekent „man”, (V.) beteekent ,vrouw”.

2) D.w.z. kinderloos bij een vrouw van gelijke geboorte. 
VIII. Laitja.

Kinderen: 1. dochter.

2. zoon, Latanri Pala (XIIde vorst).

IX. Lapatawang.

(2de kind [=2de zoon] v. h. 6de kind [= ?de zoon] v. d. Vden vorst).

Kinderloos.

X. Watanri-Toeppoe.

(3de kind $[=3$ de dochter $]$ v. h. 7 de kind $=[$ zoon $(2 \mathrm{de}$ huwelijk)] v. d. VIden vorst).

Kinderen: 1ste huwelijk:

2 zoons, 2 dochters.

2de huwelijk:

1 zoon.

XI. Latanri-Roewe.

(zoon van het 4 de kind [ $=$ ?de dochter $]$ v. d. VIden vorst).

Kinderen: 1. dochter.

XII. Latanri-Pala.

(2de kind $=$ oudste zoon v. d. VIIIsten vorst).

Kinderen: 1. dochter.

2. zoon.

XIII. Lamadarěmma.

(zoon v. d. oudste dochter v. d. VIIIsten vorst).

Kinderen: 2 zoons.

1 dochter.

XIV. Latanri-tata-Toöeroeng, Aroe Palakka.

(oudste zoon v. d. dochter v. d. XIden vorst).

Kinderloos.

XV. Lapataoe.

(zoon v. d. oudsten zoon van den XIIIden vorst).

Kinderen :

1ste vrouw: 1. dochter, Batari Todja (XVIde en XXste vorstin).

2de vrouw: 2..dochter, vroeg gestorven.

3. zoon, Lapadang Sadjati Towapawara (XVIIde vorst). 
vrouwen v. mindere geboorte: 6. zoon.

4. zoon, Laparappa Posappewalié

(XVIIIde vorst).

5. zoon, Lapanaongi Toepawawoi (XIXde vorst).

7. zoon.

8. zoon, Lama'pasossong Djaliloeddin Abdulradjab Datoe Baringang (XXIste vorst).

XVI. Batari Todja.

(Zie onder XVden vorst).

Kinderloos.

XVII. Lapadang Sadjati Towapawara.

(Zie onder XVden vorst).

Kinderloos.

XVIII. Laparappa Tosappewalié.

(Zie onder XVden vorst).

Kinderen: 3 zoons.

XIX. Lapanaongi Toepawawoi.

(Zie onder XVden vorst).

Kinderen: onbekend.

$\mathrm{XX} .=\mathrm{XVIde}$ vorstin

XXI. Lama'pasossong Djaliloeddin Abdulradjab.

(Zie onder XVden vorst).

Kinderen: 1. dochter.

2. zoon.

XXII. Latanri Toeppoe.

(zoon van dochter v. XXIsten vorst, gehuwd met dochter v. zoon XXIsten vorst).

Kinderen: 1. zoon, Toapatoenroe (XXIIIe vorst).

2. dochter, I-Maneeng Aroe Data (XXIVste vorst).

3. zoon, Mapaseleng Aroe Panjili (XXVste vorst).

4. zoon.

5. zoon.

XXIII. Toapatoenroe Aroe Palakka.

(Zie onder XXIIsten vorst).

Kinderen: 1. dochter. 
XXIV. I Maneeng Aroe Data.

(Zie onder XXIIsten vorst).

Ongehuwd.

XXV. Mapaseleng Aroe Panjili.

(Zie onder XXIIsten vorst).

Kinderloos.

XXVI. Laparenrengi Aroempoegi ( $\dagger$ 1858).

(zoon van 4 de kind $(=3$ de zoon) van XXIIsten vorst en gehuwd met XXVIIste vorstin).

Kinderen: 1. zoon $(\dagger$ 1860).

2. dochter.

3. dochter.

4. dochter.

XXVII. Basse Kadjoewara.

(dochter van 5 de kind (=4de zoon) van XXIIsten vorst).

Kinderen: zie onder XXVIsten vorst.

XXVIII. Achmad Singkerroeroekka.

(oudste zoon van dochter van XXIIIsten vorst).

Kinderen :

1ste huwelijk: zoon, Lapawawoï Karaëng Segeri (XXXste vorst).

2de huwelijk: dochter, I Banri Datoe Tjitta Aroe Timoeroeng (XXIXste vorstin).

XXIX. I Banri Datoe Tjitta Aroe Timoeroeng.

(Zie onder XXVIIIsten vorst).

Kinderen: 1. dochter.

XXX. Lapawawoï Karaëng Segeri, laatste vorst van Bone. (M.)

Laten wij thans de lijst der Gowasche vorsten aandachtiger beschouwen.

Het eerst valt op, dat slechts mannen den Gowaschen troon bestegen hebben.

Het tweede belangrijke punt is dit: op één uitzondering, de opvolging namelijk van den XIXden vorst door den XXsten, na, die wij zoo aanstonds zullen bespreken, zijn slechts afstammelingen in de mannelijke lijn van Toe-ma'noeroenga door de eeuwen heen vorst geworden. Tot en met den XXsten vorst blijkt dit uit de lijst zelf 
overduidelijk, doch ten aanzien van eenige daarna vallende troonsopvolgingen is nadere toelichting gewenscht. De XXIste vorst van Gowa, Mapaoerangi Soeltan Siradjoeddin, in de lijst slechts aangeduid als vorst van Tallo, is een lijnrechte afstammeling in de mannelijke lijn, van Toe-natangka-lopi, den VIden vorst van Gowa, die het toen nog kleine rijkje Gowa in twee deelen naliet aan zijn twee zoons : het eene deel, dat Gowa bleef heeten, kwam aan Batara Gowa, het andere, dat den naam van Tallo zou dragen, aan Karaëng-Lowéri-Sero. Ook de XXIVste vorst is een lijnrechte afstammeling in de mannelijke lijn, daar zijn vader, vorst van Tallo, een zoon is van den XXIsten (tevens XXIIIsten) vorst van Gowa. De verwantschapsverhouding tusschen den XXIXsten en den XXXsten vorst van Gowa heb ik niet kunnen vaststellen. Zeker is evenwel, dat zijn afstamming in de mannelijke lijn van Toe-ma'noeroenga onverdacht is. De XXXIIste vorst I Koemala is een kind, gesproten uit het huwelijk van een zuster en een neef van den XXXIsten vorst. Door dezen neef, van vaderszijde, is ook de afstamming van I Koemala boven allen twijfel verheven.

Een derde punt, dat aandacht vraagt, is het feit, dat van de 32 vorsten er 19 opgevolgd werden door een zoon en 7 door een broeder. Met de ons ter beschikking staande gegevens is niet vast te stellen of primogenituur immer van invloed was op de erfopvolging. Tegenwoordig wordt evenwel aangenomen, zoowel door de vooraanstaande leden van het Gowasche vorstenhuis als door leden van hoofdengeslachten, dat de oudste der in leven zijnde zoons van den regeerenden vorst de aangewezen troonsopvolger is. Heeft de vorst geen zoons, dan komt de oudste der in leven zijnde broeders van den vorst in aanmerking.

Als vierde punt eischt de invloed van de bij een Gowasche vorstenkeuze betrokken personen en lichamen nadere beschouwing. De XVIde vorst van Gowa, Malombasang Hasanoeddin, geboortig uit een moeder van geringe afkomst, komt op den troon na het overlijden van zijn vader, den XVden vorst van Gowa, dank zij den tevoren door dezen laatsten kenbaar gemaakten wil. De hoofden, vermoedelijk de „batesalapang”, de negen kiesheeren, komen in verzet, doch daar de in aanmerking komende vorstentelgen van zuiveren bloede niet verkozen wenschen te worden, blijft Hasanoeddin op (en troon ${ }^{1}$ ).

Eerst na 16 jaren doet hij afstand ten behoeve van zijn zoon Mapa-

1) „Beknopte Geschiedenis enz.”, blz. 13; - Ligtvoet, „Dagboek van de vorsten van Gowa en Tallo", 5 November 1653. 
somba. Weer is het de wil van den regeerenden vorst, die den opvolger bepaalt, ditmaal zonder dat wij iets vernemen omtrent oppositie van eenigerlei zijde.

Mapasomba, de XVIIde vorst sterft onverwacht na een zeer korte regeering. Als XVIIIde vorst wordt zijn halfbroeder verkozen. Deze, Mapa'osong, wordt door de Nederlanders - de vertegenwoordigers van de Oost-Indische Compagnie - afgezet en in zijn plaats wordt aangesteld zijn oudere broeder, de vorst van het rijkje Sanrabone, Mapadoelang. Daar Mapadoelang niet ,overeenkomstig de oude instellingen" door de rijksgrooten tot vorst was angesteld, doch door de Compagnie en haar bondgenoot, den beroemden Aroe Palakka, ontstond ontevredenheid onder de voornaamste prinsen, van welke enkelen uitweken en zich met goedvinden van de Compagnie te Makassar vestigden ${ }^{1}$ ).

Op zeer merkwaardige wijze komt Mapadoelangs opvolger op den troon. In 1687 had in Aroe Palakka's residentie Bontowala, het huwelijk plaats gehad van $\mathrm{La}$ Pataoe, den door Aroe Palakka aangewezen troonopvolger in Bone, een zoon van diens zuster, met de dochter van den koning van Gowa, waarbij bepaald werd, dat de eerste zoon uit dit huwelijk zijn grootvader Mapadoelang, ook genaamd Abdoel Djalil, zou opvolgen ${ }^{2}$ ).

Dit is een zeer sterk voorbeeld van de macht, die te dien tijde Aroe Palakka, de vriend van Speelman, op Zuid-Celebes bezat. Het successiestelsel van Gowa, dat tot dusver slechts opvolging in de mannelijke lijn had gekend, wordt terzijde geschoven en het moet plaats maken voor dat van Aroe Palakka, het Bonesche. De eerste zoon uit dit huwelijk, Sapoewali genaamd, komt inderdaad op den troon van Gowa, in 1709, doch in 1711 wordt hij door de rijksgrooten afgezet en in zijn plaats wordt aangesteld de regeerende vorst van Tallo, Mapaoerangi, later genoemd Soeltan Siradjoeddin. Grootere aanspraken op den troon had zekere Karaëng Bontolangkasa, doch deze had zulk een slechten naam, dat hij door de rijksgrooten werd gepasseerd ${ }^{3}$ ).

Bovenstaande troonsopvolgingen zijn voor ons voldoende om een inzicht te verkrijgen in de verschillende krachten, die optraden alvorens een vorst van Gowa den troon besteeg. Wij zien den regeerenden vorst van Gowa invloed uitoefenen op de keuze van zijn

1) B. Erkelens, „Geschiedenis van het rijk Gowa”, blz. 97.

2) Erkelens, t.a.p. 98 .

3) Erkelens, t.a.p. 99, 100. 
opvolger, zelfs zóóveel invloed, dat een zoon, verwekt bij een vrouw van geringe afkomst, hem opvolgt. Het verzet van de hoofden, vermoedelijk de negen kiesheeren, andere bij de vorstenkeuze optredende krachten, baat niet, daar de voor den troon in aanmerking komende vorstentelgen, - die alweer even zoovele krachten vertegenwoordigen -, niet verkozen wenschen te worden. Zien wij eerst naast den regeerenden vorst ook de kiesheeren en de prinsen de vorstenkeuze beinvloeden, in later tijd verschijnt ook de Oost-Indische Compagnie ten tooneele en verwerft zelfs een vorst van een ander rijk op ZuidCelebes medezeggenschap. Des te merkwaardiger is het, dat tot en met den laatsten vorst, de Gowasche erfopvolging, afgezien van den onder den invloed van Aroe Palakka beganen misstap, de eeuwen door een patrilineaal karakter heeft behouden. Dit blijkt het kader, waarbinnen de successie zich voltrekt en waarbuiten de Nederlanders, als zij verschillende malen ingrijpen, zich evenmin wagen als de regeerende vorst, de kiesheeren en de voorname leden van het vorstenhuis.

Indien wij de successie in het Gowasche vorstenhuis kort willen karakteriseeren, kunnen wij, met vooropstelling van het feit, dat in beginsel slechts de ,ana'-tino" " voor de vorstelijke waardigheid in aanmerking kunnen komen, zeggen dat deze (1) patrilineaal was; dat (2) vermoedelijk het beginsel der primogenituur heeft gegolden; dat (3) bij ontstentenis van zoons van den overleden of afgetreden vorst de broeders van dezen in aanmerking kwamen en dat (4) over het geheel genomen de regeerende vorst, de kiesheeren en de voorname leden van het vorstengeslacht zich binnen dit systeem bewogen. Tenslotte (5) konden de kiesheeren den vorst - waarschijnlijk zoo hiertegen van de zijde der voornaamste vorstentelgen geen bezwaar bestond - afzetten en zij konden prinsen van slechten levenswandel bij de vorstenkeuze voorbijgaan.

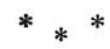

Wat ons in Bone het eerste treft is, dat hier wèl vrouwen op den troon kunnen komen. Toch zal het geen toeval zijn, dat het aantal mannelijke vorsten 23 , het aantal vrouwelijke slechts 7 bedraagt. Uit deze cijfers blijkt duidelijk, dat er een tendentie bestond aan mannen de voorkeur te geven. Van de 5 zoons, die wij den Boneschen troon zien bestijgen, zijn er 4 die oudere zusters passeeren. Slechts éénmaal gaat een dochter vóór een ouderen broeder. Vijf zoons volgen op, tegen drie dochters, zes broeders tegen twee zusters.

Het tweede punt is eveneens van belang. Wij zien namelijk bij de 
vorstenkeuze waarde toegekend zoowel aan de afstammelingen in de mannelijke lijn, als aan die in de vrouwelijke lijn.

Het beginsel der primogenituur, dit als derde punt, heeft vermoedelijk niet gegolden.

Ten vierde kunnen wij het volgende constateeren. In het begin van dit hoofdstuk zeide ik terloops, dat bij één auteur ${ }^{1}$ ) zelfs gesproken werd van een successie in het koningsschap, die rekening hield met de kinderverdeeling. Een vorst zou altijd worden opgevolgd door een van zijn (even) kinderen, een vorstin immer door een van haar (oneven) kinderen. In Gowa zagen wij reeds, dat daar slechts mannen de vorstelijke waardigheid konden bekleeden. In Bone is eveneens, zooals met een enkelen blik is vast te stellen, van een dergelijken regel geen spoor te vinden.

Evenals in Gowa is het ook hier instructief, eenige bepaalde gevallen van troonsopvolging nader te bezien. $\mathrm{Bij}$ het beschouwen van de hiervoor gegeven lijst zal de vraag rijzen, waarom - dit als eerste geval - het tweede kind van den VIIIsten vorst van Bone, Latanri Pala, toen zijn vader opgevolgd moest worden, werd gepasseerd. De IXde vorst was een kleinzoon van den Vden vorst, d.w.z. een volle neef van den VIIIsten. Als Xde op den Boneschen troon treedt een volle nicht van Latanri Pala op, en als XIde een volle neef. Dan pas komt Latanri Pala aan de beurt. $\mathrm{Nu}$ wordt nergens de reden vermeld, waarom Latanri Pala zoo lang heeft moeten wachten, doch voor mij, die zoo lang in het land zelf gewoond heb, is de veronderstelling niet gewaagd, dat deze schuilt in den haat, die het volk zijn vader, den VIIIsten vorst, toedroeg. Deze werd na zijn dood genaamd „Matinrowe-ri-adenena” d.w.z. „Hij, die op zijn trap is gestorven.” Hij werd namelijk, naar men zegt, op zijn eigen paleistrap doodgeknuppeld. $\mathrm{Nu}$ kan het bezit van een gehaten vader-voorganger zeer wel een beletsel voor den zoon zijn om tot diens opvolger te worden gekozen. Mij is uit mijn bestuurservaring een dergelijk geval bekend.

De XIIde vorst had geen zoons van zuiveren bloede. Tot zijn opvolger wordt dan, met goedkeuring van den toenmaals machtigen Gowaschen vorst, verkozen een zusterszoon ${ }^{2}$ ).

Aroe Palakka, de XIVde vorst, de sterke man van Zuid-Celebes in dien tijd, die Bone met behulp van de Compagnie van het juk der Gowasche overheersching had bevrijd, wordt door de rijksgrooten

1) Spat, „De rijkssieraden van Loewoe”, Ned.-Indië Oud en Nieuw, 3, (1918-1919).

2) „Beknopte Geschiedenis enz.”, blz. 30-31. 
van Bone, met voorbijgaan van den eigenlijken erfprins, om met Blok te spreken, verkozen ${ }^{1}$ ).

Aroe Palakka zelf had geen kinderen. Hij wees reeds bij zijn leven tot zijn opvolger aan Lapataoe, een zoon van den oudsten zoon van Aroe Palakka's voorganger. Deze XVde vorst bepaalde bij zijn leven, dat zijn oudste kind, zijn dochter Batari Todja hem zou opvolgen. Zij volgt hem op, doch doet na eenigen tijd afstand van den troon ten behoeve van haar oudsten broeder Lapadang Sadjati. De rijksgrooten zetten dezen af, - en al zeer spoedig - en verkiezen wederom Batari Todja, die haar koninklijke waardigheid overdraagt aan haar tweeden broeder Laparappa. Ook deze wordt afgezet door de rijksgrooten, die dan den daaropvolgenden broeder van Batari Todja verkiezen. Deze, Lapanaongi gedraagt zich reeds in de eerste dagen van zijn optreden niet volgens de étiquette en wordt na vier dagen afgezet. Als XXste regeert dan de vrouw, die reeds tevoren koningin van Bone was geweest: Batari Todja. Als zij kinderloos sterft, wordt zij opgevolgd door haar jongeren halfbroeder Lama'pasossong, wiens moeder van mindere geboorte is, zoodat hiermede het bloedgehalte van het Bonesche vorstenhuis daalt.

Uit deze voorbeelden wordt duidelijk, hoe groot niet alleen de wil van een regeerend vorst inzake de troonsopvolging kon zijn, doch ook welk een macht ten dezen de rijksgrooten konden uitoefenen, een macht, die veel sterker aan den dag treedt dan in Gowa en ook inderdaad altijd veel krachtiger is geweest. Het voorbeeld van buitenlandschen invloed ontbreekt ook hier niet: zie de keuze van den opvolger van den XIIden vorst.

Geven wij thans een korte karakteristiek van de successie in Bone. Wij zien dan, met vooropstelling van het feit, dat ook hier in beginsel slechts de leden van den hoogsten stand voor de vorstelijke waardigheid in aanmerking komen, dat (1) zij bilateraal is, (2) mannen en vrouwen den troon kunnen bestijgen, doch mannen de voorkeur hebben, (3) primogenituur van bijkomstige beteekenis is, (4) vermoedelijk zoons en dochters van een vorigen vorst of vorstin de voorkeur hebben en daarna broeders en zusters, terwijl in het verkiezen van meer verwijderde verwanten van den het laatst aan het bewind geweest zijnden vorst of vorstin geen stelselmatigheid is te ontdekken. Voorts (5) kan de invloed van den regeerenden vorst zeer groot zijn, doch niet minder die van de rijksgrooten. Het voorbijgaan van, in het oog

1) „Beknopte Geschiedenis enz.”, blz. 35. 
van de rijksgrooten en ook van den regeerenden vorst, ongeschikte naaste verwanten ten behoeve van geschiktere verre verwanten, komt veel vaker voor dan in Gowa. Ook het afzetten van vorsten en vorstinnen door de rijksgrooten behoort in Bone minder tot de uitzonderingen.

De erfopvolgingssystemen van de twee voornaamste rijken van Zuid-Celebes werden hierboven uitvoerig behandeld. De schaarsche gegevens, die omtrent andere Boegineesche en Makassaarsche rijkjes te vinden zijn, geven, tezamen met eigen bevinding, de zekerheid, dat het Gowasche stelsel in hoofdzaak geldt voor de Makassaarsche gebieden en het Bonesche in hoofdzaak voor de Boegineesche.

IV.

Hoewel het niet mijn voornemen is, op deze plaats te trachten het wezen van de voor Zuid-Celebes zoo belangrijke rijkssieraden of ,ornamenten", zooals deze voorwerpen door het Europeesche bestuur daar te lande vanouds worden genoemd, te doorgronden, moet ik toch aan deze materie eenige bladzijden wijden, wil ik het verband, dat tusschen den hoogsten stand en de rijkssieraden bestaat, eenigszins duidelijk maken.

Op dit terrein ontmoeten wij onmiddellijk de stelling, die door vrijwel alle schrijvers over de rijkssieraden bij de Boegineezen en Makassaren wordt verkondigd of aanvaard: „Hij, die de rijkssieraden in handen heeft, bezit daarmede de regeermacht" ${ }^{1}$ ). $\mathrm{Nu}$ is het zeker, dat tusschen vorstelijke waardigheid en ,gaoekang” (Mak.) en ,"gaoekěng” of ,,aradjang” (Boeg.) een innig verband bestaat, doch of dit verband zijn juiste weergave vindt in evengencemde stelling, is een vraag, die wij thans nader onder het oog zullen hebben te zien.

Laten wij hem aan het woord, die dit standpunt bij mijn weten het eerst heeft verdedigd, namelijk P. J. Kooreman in zijn „De feitelijke

1) Dr. B. F. Matthes, Mak.-Holl. Woordentoek, A'dam 1859, blz. 111. P. J. Kooreman, „De feitelijke toestand in het Gouvernement Celebes en Onderh.”, Ind. Gids, 1883, I, blz. 186 e.v. - A. J. A. F. Eerdmans, „Het Landschap Gowa", Verh. Bat. Gen. 50, (1895-1897), blz. 63. - A. Spoor Ir., "Een en ander omtrent de Inheemsche rechtsgemeenschap, in het bijzonder de boegineesche, in het rechtstreeks bestuurd gebied van het Gouvernement Celebes en Onderhoorigheden", Kol. Tijdschrift, XVII. [Hoewel Spoor zich hierover niet positief uitlaat, is deze stelling toch onvermijdelijk verbonden aan zijn constructie van het ,gaoekang"-begrip]. - Dr. J. Mallinckrodt. Nagelaten aanteekeningen. [,De beschikkingsmacht over die voorwerpen is onverbrekelijk verbonden aan de vorstelijke waardigheid. Indien een ander zich van de macht over die goederen zou kunnen verzekeren, zou daarmede de waardigheid van Maradia op den usurpator overgaan"]. - Wilken, Verspreide Geschriften, 1912, 
toestand in het Gouvernementsgebied van Celebes en Onderhoorigheden" ${ }^{1}$ ). Ik nummer gemakshalve de voorbeelden.

„Dat het gezag aan de ornamenten wordt ontleend heb ik zelf ondervonden."

Eerste voorbeeld. „Toen ik in 1876 waarnemend Assistent-Resident der Zuiderdistricten was, stierf de regent van Bonthain, en werden al de Bonthainsche ornamenten, waaronder ook het gouden beeldje Karaëng Lowé genaamd, in mijn huis bewaard. Blijkbaar beschouwde men mij toen als de bewaker, want nimmer zoo lang ik op Zuid Celebes gediend heb, werden mijn bevelen zóó stipt opgevolgd, en nimmer toonde men voor mij zóóveel ontzag.

Tweede voorbeeld. Hetzelfde was het geval, toen in 1879 de ornamenten van Montjongkomba (Polombangking) op mijn bureau werden bewaard. Bij die gelegenheid viel dit te meer in het oog, omdat de bevolking, voordat ze in mijn bezit waren, een begin van verzet toonde.

Derde voorbeeld. Bij elken opstand tot verdrijving van den vorst, tracht men zich het allereerst in het bezit van de ornamenten te stellen. Gelukt dat, dan is hem feitelijk het gezag ontnomen.

Een voorbeeld uit den jongsten tijd is de samenzwering tegen den vorst van Goa in 1865 of 1866.

Het gelukte aan de samenzweerders, geleid door den Glarang Mangasa, zich gedurende de afwezigheid van den vorst, die zich te Kindang bevond, meester te maken van de Goasche ornamenten, en zonder tusschenkomst van het Gouvernement, waarbij zich wijlen J. A. Bakkers wederom door zijn energiek optreden onderscheidde, zou het misschien met het bestuur van dien vorst gedaan zijn geweest, en zeker veel moeite en inspanning hebben gekost om hem in zijn gezag te herstellen. De ornamenten werden achterhaald, aan den vorst van Goa teruggegeven, die daardoor zijn gezag herwon, en de samenzweerders werden streng, zelfs onmenschelijk gestraft.

Vierde voorbeeld. Bij den moord op den regent van Boelo Boelo (vergis ik mij niet, in 1872) werden de ornamenten door de moordenaars, bij wie het voornemen bestond tegen het Gouvernement in opstand te komen, medegenomen. Hun plan mislukte door de flinkheid van den Assistent-Resident Holz.

III, blz. 139. - J. G. Frazer, „The Golden Bough” 3, I, The magic Art, I, 363, London 1911. - H. J. T. Johnson in Hastings Encyclopaedia of Religion and Ethics, X, 632 onder Regalia. - Encyclopadie van Ned.-Indië, I, 326 onder Boegineezen.

1) De Indische Gids, 1883, I, blz. 186 e.v. 
Vijfde voorbeeld. Tijdens den opstand van Karaëng Bonto-Bonto liep herhaaldelijk het gerucht, dat hij zich van de ornamenten van Lebakkang meester maken en daardoor tot vorst van Lebakkang opwerpen zou. Zonder twijfel zullen redenen, die niet ver te zoeken zijn, hem daarvan terug gehouden hebben, maar de inlander zag die niet in, waaraan het waarschijnlijk toegeschreven moet worden, dat Karaëng Bonto-Bonto naar veler meening een eigen ornament bezat."

Tot zoover Kooreman.

Eerdmans zegt ${ }^{1}$ ) van de ,Soedang”, een van de voornaamste rijkssieraden van Gowa: "Wie dit wapen in zijn bezit heeft, wordt door het volk als vorst erkend" ${ }^{2}$ ), en vervolgt dan:

Zesde voorbeeld. „Vandaar de oorlogen en beroeringen, welke van 1777 tot 1814 Gowa inwendig verscheurden, toen het ornament in handen van Bone's vorst was en de z.g. berg-Makassaren, waaronder de bevolking der bergstreken verstaan moet worden, niet den wettigen vorst van Gowa, maar dien van Bone als hun heer en meester erkenden." Het loont de moeite iets meer van die oorlogen en beroeringen te leeren kennen. Daarvoor slaan wij het artikel van Erkelens ${ }^{3}$ ) op. Ik citeer :

„In 1760 komt de rijksbestierder van Gowa, Koning van Tallo te sterven en wordt in zijn plaats als rijksbestierder aangesteld zijn broeder Karaëng Tamasongo, die den 23sten Mei 1761 de contracten ${ }^{4}$ ) beëedigt. Hij volgt echter zijn broeder niet op als Koning van Tallo. Batara Gowa ${ }^{5}$ ), misnoegd over verschillende handelingen, hem door den Rijksbestierder en andere rijksgrooten aangedaan, verlaat in Augustus 1766 zijn rijk en neemt de wijk naar Bima, maakt zich aan zeeroof schuldig, wordt eindelijk op last der Regeering gevangen genomen en naar Batavia opgezonden, van waar uit hij naar Ceijlon wordt verbannen.

De rijksornamenten worden voorloopig aan den rijksbestierder in bewaring gegeven.

Door de rijksgrooten werd in het volgend jaar - 1767 - Batara Gowa's broeder, Aroe Mampoe, tot koning van Gowa verheven. Nadat hij bekend geworden was met de verbanning van zijn broeder en herhaaldelijk, doch vruchteloos, diens terugkeer had verzocht, deed

1) „Het Landschap Gowa”, Verh. Bat. Gen., 1897, deel L, 3e stuk, blz. 63.

2) Cursiveering, ook in de volgende citaten, steeds van mij.

3) B. Erkelens, „Geschiedenis van het rijk Gowa”, blz. 103 e.v.

4) Met de Oost-Indische Compagnie.

5) De toenmalige vorst van Gowa. 
hij in Januari 1769 afstand van den troon, waarop de rijksbestierder, Karaëng Tamasongo, in zijn plaats tot koning werd verkozen, onder den naam van Soeltan Zainoeddin. Den 30sten Augustus 1770 had de renovatie der contracten door hem plaats.

Tot 1776 bleef de rust in Gowa ongestoord. In dat jaar stond echter een zekere Sangkilang op, een weggeloopen slaaf van den Bonischen prins, Patimbing, die zich voor den naar Ceijlon verbannen Batara Gowa uitgaf en zich weldra een aanzienlijken aanhang verwierf, waaronder zelfs de weduwe Aroe Palakka (Batara Gowa's grootmoeder), 2 zonen van den koning Zainoeddin en de vorsten van Sanrabone en Tallo. Sangkilang's aanhang nam zoo toe, dat de koning genoodzaakt werd Gowa te verlaten en zich onder de bescherming van de Compagnie te stellen, die hem de kampong Matowanging, ten Zuiden van Makassar gelegen, tot verblijfplaats aanwees.

$\mathrm{Na}$ zijn vertrek werd Sangkilang door geheel Gowa als koning erkend, maar door de standvastigheid van den Gouverneur Van der Voort werd de hoofdplaats Gowa, na een belegering van een jaar, in 1779 herwonnen, Sangkilang naar het gebergte teruggedreven en de zoon van den te Matowanging overleden koning, Zainoeddin, tot koning van Gowa aangesteld en door de Compagnie in Bone erkend onder den naam van Karaëng Mangasa (aldus naar zijn verblijfplaats genoemd).

Eenige Makassaarsche hoofden echter in de binnenlanden erkennen hem niet als hun koning, daar hij de Soedang niet in handen heeft.

Nog wel 30 jaar lang bleef er in het Gowasche rijk eene scheuring bestaan tusschen de zoogenaamde strand-Makassaren, die aan hun wettige vorsten getrouw bleven, en de berg-Makassaren, die Sangkilang aanhingen en na diens dood, in Juni 1785, den koning van Bone als opperheer erkenden, omdat deze na de inneming van de plaats Gowa in 1779, in het bezit van de voornaamste ornamenten, waaronder de Soedang, was gekomen, bij de vlucht van de weduzve Aroe Palakka door haar medegenomen."

Karaëng Mangasa, van wien zich meer en meer onderdanen verwijderen, wil in 1790 afstand doen van den troon. Verscheidene hoofden der uitgeweken Gowareezen, waaronder ook Aroe Mampoe, worden op aandringen van den koning van Bone in genade aangenomen. Verzekerd van den steun van dezen, spant de koning van Bone alle krachten in om zich als koning van Gowa te doen huldigen en doet zich onder de zijnen reeds als zoodanig uitroepen. De regee- 
ringsloosheid, waaraan Gowa feitelijk ten prooi is, drukt het zeer".... „De overwinning van Sidenreng, Tanette en Barroe op Bone in 1794, aan welken oorlog, die reeds lang gesmeuld had, Gowa ook deel nam, geeft aan Gowa eenige verademing, doordat de partij, die den koning van Bone op den troon van Gowa wilde hebben, hem afvallig werd.

Had de Regeering het verzoek van den koning van Gowa, door hem in 1792 gedaan, om in de oude hoofdplaats Gowa te mogen verblijven ingewilligd, dan zouden de berg-Makassaren hem waarschijnlijk ook als vorst erkend hebben. $\mathrm{Nu}$ echter blijft verdeeldheid in Gowa heerschen, waardoor de gedrukte toestand weinig verbetert. In 1800 wordt een gedeelte der Gowasche rijkssieraden door ecn zekeren Karä̈ng Bontolebang aan den Gouverneur uitgeleverd; daaronder is echter niet de Soedang. Karaëng Mangasa, wien in 1806 vergund was zijn verblijf te houden op Samboengdjawa, overleed den 7den Mei 1810.

In afwachting van de verkiezing van een nieuwen vorst, welke door de bestaande verdeeldheid voorloopig niet kan plaats hebben, wordt zijn broeder, Karaëng Pangkadjene, tot regent van het rijk aangesteld. Deze toestand duurde voort tot 1811, toen de Engelschen de Nederlanders in het bezit van Celebes opvolgden. Zij kregen weldra geschil met den koning van Bone. Een der voornaamste geschilpunten was de weigering van dezen om de ornamenten van Gowa af to staan. Het gemis daarvan was oorzaak, dat de koning van Gowa in zijn rijk niet zooveel invloed en aanzien bezat als hem toekwam, en dat de berg-Makassaren hem in het geheel niet erkenden, maar, de Soedang volgende, den koning van Bone als hun opperheer erkenden, die daarvan gebruik maakte om Aroe Mampoe tot koning van Gowa te benoemen en in het bezit van de Soedang te stellen. Langzamerhand werd de verhouding tusschen het Engelsche bestuur en den koning van Bone zóó, dat in 1814 een expeditie naar Celebes werd gezonden onder bevel van generaal Nightingale, om aan dien toestand een einde te maken. Spoedig valt deze den koning van Bone in zijn residentie Rompegading bij Makassar ${ }^{1}$ ) aan, die genoodzaakt wordt de vlucht te nemen met achterlating van de Gowasche ornamenten in handen van den koning van Soppeng, die ze echter weder aan Aroe Mampoe overgeeft, door wien ze aan het Engelsch bestuur worden afgestaan.

Nadat in 1816 Celebes door het Nederlandsch Indische Gouver-

1) De koningen van Bone hadden meestal ook een paleis bij Makassar.

D1. 90. 
nement van de Engelschen was overgenomen, werd de rijksbestierder van Gowa, Karaëng Limbangparang, tot vorst aangesteld en tevens in het bezit gesteld van al de rijkssieraden, waardoor de beide partijen eenigszins te zamen werden gebracht en eenige rust ontstond in het vervallen rijk. Hierin echter mocht het zich niet lang verheugen, want spoedig verschijnt in Gowa weer een zoon van den beruchten Sangkilang, den valschen Batara Gowa, met name Aboe Bakar of Karaëng Data, die door zijn rooverijen en brandstichtingen het geheele land verontrust. Hij weet een aanzienlijken aanhang onder de berg-Makassaren te verkrïgen en trekt met 2000 man tegen den koning van Gowa op. Deze, bijgestaan door de Nederlandsche krijgsmacht en den vorst van Sidenreng, verslaat hem na eenigen tegenstand bij Beba, waar hij zelf wordt afgemaakt en 3 zijner zonen gevangen genomen, 1819. Hiermede was de rust in Gowa en het gezag van den koning hersteld."

Alvorens ik de gegeven voorbeelden van, tevens de bewijsgronden voor de stelling, dat ,degeen, die de rijkssieraden in handen heeft, ook de macht bezit," ga ontleden, moet ik de voornaamste eigenschappen der Boegineesche en Makassaarsche regalia naar voren brengen, zonder evenwel ook maar eenigszins naar volledigheid te streven.

In de eerste plaats dient dan de wonderdadige kracht genoemd te worden, die in meerdere of mindere mate geacht wordt uit te gaan van de verschillende ,ornamenten”. Regalia werden en worden soms nog uitgedragen bij misoogst, rampen en besmettelijke ziekten; zij vervulden en vervullen in sommige streken een rol bij grondbewerking en oogst; het is waarschijnlijk, dat allerwege in Zuid-Celebes vroeger groote jaarlijksche feesten werden gehouden ter gelegenheid van het schoonmaken der ,gaoekangs"; sommige rijkssieraden werden medegenomen ten strijde.

De staat, waarin de regalia verkeeren, hangt ten nauwste samen met het welzijn van de gemeenschap, waarbij deze regalia behooren. Het mooiste voorbeeld is wel dat van de „Tanisamaäng” ${ }^{1}$ ), de halve keten van Gowa, die vroeger eens per jaar gewogen werd. Was de keten lichter geworden, dan zouden onheilen het land teisteren; was de keten zwaarder, dan zou voorspoed heerschen.

Deze wonderdadige kracht is zóó groot, dat de meeste ornamenten slechts door de priesters, de „bissoe's” (Boeg. en Mak.), de „sanro's” (Boeg.) of ,pinati's” (Mak.), die met de ,gaoekang"-verzorging zijn

1) Zie blz. 470 . 
belast, en door den vorst of het hoofd, in wiens bezit zij zich bevinden, mogen worden aanschouwd. Indien anderen dan deze personen de regalia zouden aanschouwen, zouden zij spoedig sterven of op zijn minst zwaar ziek worden. Sommige regalia zijn, naar men gelooft, nog nooit door iemand aanschouwd. Ook de bewaarder zelf denkt er dan niet aan, de ,gaoekang” uit haar bergplaats te halen.

Vele "gaoekangs" hebben haar overlevering, die dan meestal op een of andere wijze samenhangt met de eerste vorsten of hoofden. Het zijn voorwerpen van allerlei aard: vlaggen, doeken, steenen van vaak vreemden vorm, krissen, lansen, maliënkolders, beeldjes, vazen, kommen, borden, mandjes, ploegen, gongs, een stuk van een prauw, een vischnet, een plukje haar, een knop van een vlaggestok, een kwast.

De rijkssieraden behooren op zolder te worden bewaard. Zij liggen op de vliering, meestal van het woonhuis van het hoofd, soms van een afzonderlijk huis, dat dan gemeenlijk staat op de plaats, die als de kern van het land wordt beschouwd. In dat huis woont dan ook de verzorger der rijkssieraden.

Bewaakt, in den eigenlijken zin van het woord, worden de rijkssieraden nimmer.

Keeren wij thans terug tot de vraag, die ons bezighoudt: Is het juist, dat „hij, die de rijkssieraden in handen heeft, ook de regeermacht bezit," of dat, anders gezegd, ,het gezag aan de ornamenten wordt ontleend," of dat, nog anders gezegd, ,hij, die de ornamenten in zijn bezit heeft, door het volk als vorst wordt erkend?"

Laten wij beginnen met de oorlogen en beroeringen, die van 1777 tot 1814 Gowa inwendig hebben verscheurd, en die het gevolg zouden zijn geweest van het feit, dat het volk hem volgde, die de ,gaoekang" en in dit geval het ééne rijkssieraad, de "Soedang”, in handen had.

Teneinde een behoorlijk overzicht van deze gebeurtenissen te verkrijgen, vermeld ik hieronder achter de belangrijkste jaartallen uit deze periode 1o. in wiens handen zich op dat tijdstip de "Soedang” bevond en 2o. wien tegelijkertijd het Gowasche volk volgde.

\section{Soedang.}

1760. Batara Gowa (XXVI) ${ }^{\mathbf{1}}$ ).

1766. Rijksbestierder.
Macht.

Batara Gowa (XXVI).

De rijksgrooten met den rijksbestierder aan het hoofd, daar Gowa eenigen tijd lang geen vorst heeft.

1) Het romeinsche cijfer heeft betrekking op de nummering der Gowasche vorsten in de lijst op blz. 480 en 481 . 
Soedang.

1767. Aroe Mampoe (XXVII).

1769. Soeltan Zainoeddin (XXVIII).

1776. Soeltan Zainoeddin (XXVIII).

\pm 1777. Van Soeltan Zainoeddin (XXVIII) naar PseudoBatara Gowa.

1779-1785. Vorst van Bone.

1785. Vorst van Bone.

1785-1794. Vorst van Bone.

1810. Vorst van Bone.

$$
\begin{aligned}
& \text { 1816-1819. Karaëng Lem- } \\
& \text { bangparang (XXX). }
\end{aligned}
$$

Macht. Aroe Mampoe (XXVII). Soeltan Zainoeddin (XXVIII). 1. Soeltan Zainoeddin

(XXVIII).

2. Pseudo-Batara Gowa groote aanhang.

Pseudo-Batara Gowa, wiens aanhang zoo groot is geworden dat Soeltan Zainoeddin is gevlucht. Door de vlucht is de Soedang in handen gekomen van Pseudo-Batara Gowa.

1. Karaëng Mangasa (XXIX).

2. Pseudo-Batara Gowa, aanhang bij berg-Makassaren.

1. Karaëng Mangasa (XXIX).

2. Pseudo-Batara Gowa sterft; de berg-Makassaren volgen daarna den Vorst van Bone.

1. Karaëng Mangasa's (XXIX) invloed vermindert.

2. $\mathrm{Na}$ vermeerdering van invloed wordt de partij van den Vorst van Bone dezen afvallig.

Karaëng Mangasa (XXIX) sterft.

1. Karaëng Lembangparang (XXX).

2. Aboe Bakar Karaëng Data, zoon van Pseudo-Batara Gowa groote aanhang onder berg-Makassaren.

Wanneer men de feiten zoo gerangschikt ziet, zal men op grond hiervan moeilijk tot het besluit kunnen komen, dat hij die de "Soedang" had, ook de macht bezat. Terwijl in 1776 Soeltan Zainoeddin de "Soedang" in handen heeft, krijgt iemand, die zich uitgeeft voor den naar Ceylon verbannen Batara Gowa, zooveel aanhang; zonder 
de "Soedang” te bezitten, dat Soeltan Zainoeddin genoodzaakt is te vluchten, waardoor de „Soedang” in handen valt van den PseudoBatara Gowa. Van 1779 tot 1785, dus zes jaren lang, heeft de vorst van Bone de "Soedang” in handen, terwijl de macht in Gowa in handen is van Karaëng Mangasa en de Pseudo-Batara Gowa tot aanhang heeft de, numeriek sterk in de minderheid zijnde, berg-Makassaren. Pas in 1785 erkennen deze berg-Makassaren, na den dood van den Pseudo-Batara Gowa, den vorst van Bone als hun heer. Waarom? Omdat deze de "Soedang” in handen heeft? Dit is moeilijk aan te nemen, daar het dan onbegrijpelijk is, om welke reden zij dan zes jaren den Pseudo-Batara Gowa zonder Soedang trouw zijn gebleven. In 1794, wanneer de vorst van Bone de „Soedang” reeds 15 jaren bezit - dat hij ondanks al zijn moeite dan nog geen vorst van Gowa is, kan hier niet als argument worden gebezigd, daar hier ook vreemde invloeden medewerken en wel die der Nederlanders - wordt zijn eigen partij hem afvallig. En als tenslotte in 1816 Karaëng Lembargparang de „Soedang” bezit en bovendien behoorlijk vorst van Gowa is geworden, staat plotseling een zoon van den Pseudo-Batara Gowa, Karaëng Data, op, en weet, zonder ,Soedang”, de berg-Makassaren op zijn hand te krijgen niet alleen, doch met een aanzienlijke macht naar de hoofdplaats van Gowa op te trekken.

Ik vraag thans, hoe met dit materiaal de stelling valt te verdedigen, dat het gezag ontleend wordt aan de ornamenten.

$\mathrm{Er}$ is in dit relaas nog een merkwaardigheid, die wij niet over het hoofd mogen zien. Erkelens zegt namelijk, ongetwijfeld op goede gronden: „Had de Regeering het verzoek van den koning van Gowa, door hem in 1792 gedaan, om in de oude hoofdplaats Gowa te mogen verblijven, ingewilligd, dan zouden de berg-Makassaren hem waarschijnlijk ook als vorst erkend hebben", hetgeen niet te rijmen is met het principe, dat het volk slechts de "Soedang” volgt.

Zonder het bovenstaande is het derde voorbeeld van Kooreman moeilijk te begrijpen. De verzetspoging van den Gallarrang van Mangasa vond niet in 1865 of ' 66 plaats, doch in 1868. Kooreman schijnt overigens niet geheel op de hoogte te zijn geweest, zooals moge blijken uit het verslag, dat Erkelens ${ }^{1}$ ) geeft :

„Terwijl zijne hoogheid (de vorst van Gowa)) zich met zijne bloedverwanten naar Tjalindoe-lindoe bij Bonthain had begeven tot het vervullen van een gelofte, begaf Galarrang Mangasa, de voornaamste der negen kiesheeren, zich naar Tanralili om den oud-regent,

1) t.a.p., blz. 112 . 
Tjalla Karaëng Borong, een kleinzoon van den beruchten Sangkilang, over te halen met hem naar Gowa te gaan en de koninklijke waardigheid te aanvaarden. Dit aanbod nam Karaëng Borong aan. Zij vertrokken tot uitvoering van hun plan, doch namen tegen het voorstel van Galarrang Mangasa den weg over Makassar. De Gouverneur, intusschen van deze samenzwering onderricht, liet Karaëng Borong bij zich ontbieden, vermaande hem zich niet met de zaken van Gowa in te laten en liet hem ongehinderd naar zijne woonplaats terugkeeren. Galarrang Mangasa werd gearresteerd, waarna zijn aanhangers, die reeds in grooten getale te zijnen huize verzameld en voor een groot gedeelte afkomstig waren uit de districten Songkolo en Badjing zich verstrooiden".

Erkelens zwijgt over de rijkssieraden, zooals men ziet. Doch al waren deze in handen gevallen van de samenzweerders, dan nog zou men hebben moeten afwachten, wat het resultaat zou zijn geweest. Het zou een strijd hebben kunnen worden tusschen twee troonpretendenten, die ieder voor zich van oordeel waren, dat zij recht op de macht in Gowa en ook recht op het bezit van de rijkssieraden hadden. Want - dit vermeldt Kooreman niet - degeen, die door den voornaamsten kiesheer op den troon moest worden geholpen, was een kleinzoon van den Pseudo-Batara Gowa, een kleinzoon, die er, evenals de thans nog levende nazaten, waarvan ik er eenige persoonlijk ken, zonder twijfel van overtuigd zal zijn geweest, dat de PseudoBatara Gowa de echte Batara Gowa is geweest.

De overige voorbeelden van Kooreman zijn eveneens zwak. De eerste twee zijn onvolledig en bovendien van zeer subjectieven aard. Het is niet eenvoudig, het snel uitvoeren van bevelen en het toonen van ontzag als maatstaf voor de macht der rijkssieraden te nemen, vooral wanneer men weet, dat het gezag van den bestuursambtenaar op Zuid-Celebes altijd vrij groot is geweest. Bovendien is het in het geheel niet zeker of het staken van het verzet uit het tweede voorbeeld, geen andere oorzaak had. Het vierde voorbeeld toont niet aan, dat de moordenaars van den regent van Boelo-Boelo eenige macht over de bevolking hebben gekregen, terwijl het vijfde voorbeeld, behalve dat het de opgeworpen stelling niet steunt, zelfs van iets geheel anders, en wel van een eigen ,ornament” spreekt. Dit wil dus zeggen, dat men aannam, dat Karaëng Bonto-Bonto een wonderdadig voorwerp zou hebben bezeten, dat hem een zekere bovennatuurlijke macht of eigenschap, bijvoorbeeld onkwetsbaarheid, verleende.

Bewijzen wat hij wilde bewijzen, doet Kooreman niet. Wat zeggen 
deze geschiedenissen dan wel ? Dat een vorst zonder rijkssieraden minder is dan een vorst met rijkssieraden. Doch dat niet alleen. Zij zeggen ook, dat de rijkssieraden behooren in handen van den volgens de adat aangestelden vorst. Worden zij hem ontvreemd, dan heeft de vorst zijn regeermacht niet verloren, doch dan is hij gekortwiekt, terwijl degeen, die de rijkssieraden op onrechtmatige wijze in zijn bezit heeft gekregen, nog geenszins de macht heeft.

Een vorst behoeft eerst dan voor zijn troon en zijn rijkssieraden te vreezen, wanneer er iemand is, die meer recht op dien troon of die rijkssieraden heeft of beweert te hebben, dan hij. Als werkelijk een ieder, hetzij edelman, vrije of slaaf, door de rijkssieraden in zijn bezit te nemen, de regeermacht zou kunnen verwerven, dan zou het volkomen onbewaakt zijn van de regalia onverklaarbaar moeten worden geacht. Waarom nu is Soeltan Zainoeddin gevlucht met achterlating van de ,gaoekangs"? Hoogstwaarschijnlijk omdat hij er van overtuigd was, dat de echte Batara Gowa was teruggekomen en nu weer naar de koninklijke macht streefde - op welke macht hij meer recht had dan Soeltan Zainoeddin. Ongetwijfeld is de geheele bevolking er van overtuigd geweest, met den echten Batara Gowa te doen te hebben, evenals Batara Gowa's grootmoeder en Soeltan Zainoeddin's eigen zoons in hem vertrouwden. De Pseudo-Batara Gowa had zijn grooten aanhang al, toen hij de "Soedang” in handen kreeg. Zeker, de „Soedang” brengt macht, doch niet de koninklijke.

Zou werkelijk het gezag van den vorst slechts ontleend zijn geweest aan de regalia, hoe anders zou dan de lijst van Gowasche vorsten er hebben uitgezien en hoe anders zou zich het koningsschap bij de Boegineezen en Makassaren hebben ontwikkeld. Een dergelijke, betrekkelijk starre vorstenrij, waarin de patrilineale successie zoo duidelijk naar voren treedt, zou ondenkbaar zijn.

De rijkssieraden zijn inhaerent aan de vorstelijke waardigheid; de vorstelijke waardigheid is slechts weggelegd voor hen, die van het zuiverste bloed zijn. Ergo behooren de rijkssieraden in handen van de hoogste groep.

\section{V.}

Het is zeer moeilijk van de tusschenstanden een bepaald beeld te geven; het is zelfs nirt goed mogelijk en wel omdat zij als ,tusschen"standen een eigen karakter missen. Wij zagen reeds, dat de tusschenstanden bij de indeeling in standen steeds èèn groep vormen met de groep der vorstentelgen van zuiveren bloede. Zij staan inderdaad ook 
saarschen naam „Boelang daëng Ma'tjora” beteekent „Boelang”: „maan” en „Ma'tjora": „glanzend”. Zoo heb ik in Gowa ontmoet „Tjintjin daëng Makilo” = „Ring daëng glinsterend”, „Marewa daëng Barani” = „Moedig daëng Dapper”. De „Daëng”-titel wordt vóór den „Karaëng”-titel gebruikt, zoodat men zegt: ,T jintjin daëng Mâkilo Karaëng Lengkese".

De „Daëng”-titel heeft in den loop der tijden veel van zijn aanzien verloren, doordat velen zich hem onrechtmatig hebben toegeëigend. Gegoeden uit den stand der vrijen ziet men tegenwoordig vaak den „Daëng”-titel dragen en geen Boegineesch of Makassaarsch gouvernements-ambtenaar van eenig gewicht of hij draagt, vaak ten onrechte, een „Daëng”-titel.

In de hoogste groepen kent men in de Boegineesche landen nog den vrij zeldzaam voorkomenden titel „Andi”, het best met ons „prins” te vertalen. Voorts hoort men daar ook wel den titel „Pětta” gebruiken, wat een verkorting zou zijn van „Poewangta” d.w.z. „mijn Heer”, en dan dikwijls door jongere tegenover oudere edellieden. „Pětta-mangkaoe” of „Aroe-mangkaoe” is een titel voor den regeerenden vorst van Bone.

\section{DERDE HOOFDSTUK.}

De standen af zonderlijk.

(Vervolg).

De hoofdengeslachten; de vrijen; de slaven.

I.

De hoofdengeslachten.

Hiervoor, in het eerste hoofdstuk, had ik reeds gelegenheid op te merken, dat zeer weinig hoofdengeslachten in Zuid-Celebes zich zuiver hebben weten te bewaren. Dit is allerminst alleen het gevolg van het daadwerkelijke ingrijpen der Nederlanders in den gang van zaken in deze gewesten. De opkomst der groote rijken als Gowa en Bone is de ondergang geweest voor vele hoofdengeslachten. $\mathrm{Zij}$ kwamen in het gedrang en werden ook veelal verdrongen en ver- 
vangen door gunstelingen van den vorst, voor wiens macht de hoofdengeslachten hadden moeten buigen. Wij kunnen wel aannemen, dat bij de komst der Nederlanders in de groote rijken, omstreeks 1906, de meeste hoofdengeslachten òf reeds geheel verdwenen waren, òf dusdanig waren vermengd met andere hoofdengeslachten of met vorstengeslachten, dat van zuivere geslachten, in den zin van het Gowasche vorstenhuis bijvoorbeeld, niet meer gesproken kon worden. Het Westersch bestuur, met langen tijd als eenig doel het scheppen van rust en orde in Westerschen trant, heeft toen nog het zijne gedaan. Hier overleed een Karaëng en werd vervangen door een vaccinateur, een man van geringe afkomst, omdat deze kon lezen en schrijven; daar werd een Aroe, overigens om zeer gegronde redenen, ontslagen en een zijner lagere hoofden, daar hij zoo goed was op politioneel gebied, anngesteld; elders werd een ijverig en onverschrokken lid van het kantoorpersoneel, als hoofd geinstalleerd.

Het zal duidelijk zijn, dat het door deze oorzaken thans een zware taak is geworden onder de hoofden van de in rang onder de rijken als Loewoe', Gowa en Bone staande gemeenschappen, nog een behoorlijk aantal te vinden, dat het bewind voert in een gemeenschap, waar vanouds zijn voorouders regeerden. De sporen van de oude hoofdengeslachten treffen wij echter nog in vele streken aan.

Mijn bedoeling is, op dezelfde wijze als ik dit deed ten aanzien van de groep der vorstentelgen van zuiveren bloede, een karakteristiek te geven van de groep dezer hoofdengeslachten. De gegevens zijn evenwel veel schaarscher. Bezitten de vorstenhuizen van Gowa en Bone, naar wij zagen, een geschiedenis, waardoor wij o.m. in staat waren de successie in de vorstelijke waardigheid uitvoerig na te gaan, de hoofdengeslachten kennen hoogstens overleveringen, zoo deze al bewaard zijn gebleven. Er zijn heele streken in Zuid-Celebes, vooral aan de kust en dan in het bijzonder in de gebieden, waar de voornaamste vorsten hebben geresideerd en hun druk hebben uitgeoefend, waar nog maar zeer weinig aan mythen en legenden te vinden is.

De mythen, die wij nog vinden, verhalen meestal van de hemelschen afkomst der oude hoofdengeslachten. Ik laat er hieronder eenige volgen.

De eerste twee mythen werden opgeteekend in Borisallo, een in de heuvelgebieden van Gowa liggende gemeenschap. Zij betreffen de stammoeder van de Karaëngs van Borisallo, die, volgens de overlevering, sedert den Gowaschen vorst Toe-nibatta (XI) tot de kiesheeren van het Gowasche rijk behoorden. 
B orisa 11 .

Op zekeren dag ging iemand van Pamolongang naar het bosch om ,gandjeng" (een bladsoort, die bij gebrek aan sirih gebruikt wordt) te zoeken. In dit bosch vond hij een ongeveer zevenjarig meisje, dat prachtig gekleed was en gouden armbanden en een gouden borsthanger droeg. Zij wist niet, vanwaar zij afkomstig was, waarop de menschen haar beschouwden als nedergedaald uit den hemel en haar den naam gaven van ,Toe-ma'noeroenga-ri-Pamolongang”, ,de te Pambolongang nedergedaalde mensch”. Zij werd in Pamolongang verzorgd tot zij volwassen was, waarna zij in het huwelijk trad met Karaëng Nisaoeka, den eersten Karaëng van Borisallo.

De tweede mythe is een variant op de eerste. Volgens deze mythe zou „Toe-ma'noeroenga-ri-Pamolongang” als zuigelinge zijn nedergedaald en na opgevoed te zijn in Pamolongang, gehuwd zijn met iemand, wiens naam onbekend bleef, en twee zoons en vijf dochters ter wereld hebben gebracht, en wel:

1. een zoon, genaamd Bela Poenranga;

2. een zoon, genaamd Bela Montjong;

3. een dochter, genaamd Karaëng Mangempang;

4. een dochter, genaamd Dampang Kanneya;

5. een dochter, genaamd Karaëng Toboentoeloe;

6. een dochter, genaamd Karaëng Bontodjai, en

7. een dochter, wier naam onbekend is.

Bela Poenranga wordt dan de groote legendarische held uit die streken, die Borisallo tot macht en aanzien brengt en een vriend wordt van de Gowasche vorsten.

Ook in Boronglowé, een van de grootste gemeenschappen, waaruit de kern van het Gowasche rijk bestaat, leeft nog een mythe, waarin cle hemelsche afkomst van de eerste hoofden wordt verhaald.

B or onglowé.

In oude tijden, aldus de overlevering, was Boronglowé een zelfstandig en uitgestrekt gebied. Het was in twee deelen verdeeld, namelijk het eigenlijke Boronglowé en Songkolo'. In Boronglowé regeerde destijds een vrouw, die den titel „Baoe” droeg. Over de afkomst van deze vrouw verhaalt men het volgende.

Op zekeren dag brak een zwaar onweder over Boronglowé los; de bliksemflitsen waren niet van de lucht. Toen alles weer tot rust kwam 
ontdekte men in een bosch ten Westen van de nederzetting Songkolo, dat daar plotseling, als uit den grond gerezen een groot en geheel ingericht huis stond. Het bestond uit zeven vertrekken en in één daarvan bevond zich een jonge schoone vrouw, die in haar eene hand een vlag hield, - die den naam van „Tampeng Pakere” kreeg —, en in de andere een aan weerszijden scherpe ,badi”. De scheede van de „badi” was geheel van goud; de scheederingen waren van gebrand goud en zoo dik als een kindervuist; ook het gevest was van gebrand goud, evenals de schoen van de scheede. Deze vrouw werd beschouwd als „Toe-ma'noeroeng”, en door de toen nog weinig talrijke inwoners tot vorstin gekozen. Haar naam was Saoenia. De plaats, waar zij nederdaalde werd genoemd ,Sokkolia”, d.w.z. ,de met geluk begunstigde”. Later veranderde deze naam in „Songkolo”. Veertien dagen, nadat Saoenia in Boronglowé was neergedaald, bemerkte zij, dat zij zwanger was. Drie jaren duurde deze zwangerschap, waarna haar een zoon geboren werd. Toen hij ter wereld kwam, aldus het verhaal, werd plotseling het huis zeer helder verlicht, zonder dat er echter een lamp brandde. Door zijn moeder werd hij, toen hij volwassen was, belast met het bewind over Boronglowé. Hij droeg toen den naam van „Goentoerroe' Mangoelappaka” d.w.z. „,eeuwigdurende donder”. Goentoeroe' Mangoelappaka huwde met Sadalle, een zuster van den Lagaroeda (het hoofd) van Lassang in Polombangkeng. Zij was de tante van den eersten Dampang van Lassang, die dezen Lagaroeda, zijn vader, opvolgde in het bewind over Lassang. Uit het huwelijk van Goentoeroe' Mangoelappaka en Sadalle sproten twee zoons voort, die beiden het gezag over een eigen gebied kregen uit te oefenen. De oudste vestigde zich in 'Songkolo', de jongste in Boronglowé, beiden den titel van Dampang dragende. Destijds droeg Boronglowé nóg den naam van Borong d.w.z. ,,verzameling”, ,bijeenkomst”. Later, zegt men, toen het land dichter bevolkt was, kreeg het den naam „Boronglowé”, ,groote verzameling”.

Als Goentoeroe' Mangoelappaka en zijn moeder Baoe zagen, dat de beide zonen reeds zelfstandig het bestuur over Borong. en Songkolo' konden voeren, besloten zij zich uit de wereld terug te trekken. Daarom verzamelden zij alle inwoners van -Borong-en Songkolo', en terwijl zij beiden op een groote steen gezeten waren, deelden zij aan de menigte mee, dat zij de aarde wilden verlaten. Op hetzelfde oogenblik brak een vreeselijk onweder los, een bliksemstraal trof den steen, waarop beiden gezeten waren, en Baoe en Goentoeroe' Mangoelappaka waren verdwenen. 
Boronglowé schijnt nimmer langen tijd één en hetzelfde geslacht aan het bewind te hebben gehad. Vermoedelijk door Gowa's suprematie was er herhaaldelijk wisseling in de regeerende geslachten.

Gaan wij meer naar het Zuiden, naar het Takalarsche, dus verder buiten de onmiddellijke invloedssfeer van het Gowasche hof, dan vinden wij meer van dergelijke mythen. Zoo omtrent de nederdaling van den eersten vorst van het reeds lang verdwenen, volgens de overlevering door Gowa vernietigde rijk van Badjing, den „KaraëngLowé-ri-Badjing”, den ,grooten vorst van Badjing”; zoo over de nederdaling van den „Karaëng-Lowé” van Malewang, den „KaraëngLowé” van Lassang, den „Karaëng-Lowé” van Pangkalang, den „Karaëng-Lowé” van Galesong, den „Karaëng-Lowé” van Djipang en den „Karaëng-Lowé” van Katingang.

Nog twee mythen mogen hier volgen. Ik vond deze in een nota van den Zuid-Celebeskenner O. M. Goedhart ${ }^{1}$ ).

Kalimporo.

„Volgens de volksoverlevering werd het gebied van de huidige districten Bangkala en Laikang in overoude tijden ingenomen door een groot aantal van elkander onafhankelijke staatjes, elk waarvan bestuurd werd door een hoofd met den titel van Kare.

Op zeker tijdstip verschenen in het meest Oostelijk gelegene van die staatjes, Kalimporo geheeten, twee vreemdelingen, een man en eene vrouw, die beweerden uit den hemel te zijn nedergedaald, derhalve ,toe-manoeroengs" te zijn. De bevolking van Kalimporo sloeg aan hun verhaal geloof en riep hem ${ }^{2}$ ) tot Karaëng uit. Het bericht omtrent hunne bovennatuurlijke afkomst geraakte spoedig wijd en zijd bekend, met het gevolg dat hoofden en bevolking van de meer westwaarts gelegen staatjes naar Kalimporo kwamen om aan beide „toe-manoeroengs" hun hulde te betuigen. Men noemde hen weldra „Karaëng-Lowé ri Kalimporo” (de grootste vorsten van Kalimporo) en stelde hen op een lijn met de Karaëngs-Lowé ri Bantaëng (Bonthain), Katingang (het latere Sanrabone), Badjing (het latere Polombangkeng), Maroesoe (door ons tot Maros verbasterd), Barasa (het latere Bone) en Loe of Loewoe."

Bangkala.

„Een dochter van „Karaëng-Lowé ri Kalimporo” trad in den echt met Karaëng Paoerang, een zoon van den Karaëng-Lowe van Ban-

1) Adatrechtbundel XXXI, blz. 312 e.v.

2) „Hem" of ,hen"? 
taëng. Deze was een hartstochtelijk jager. Op zekeren dag kwam hij al jagende in het gebied van Kare van Oedjoeng-montjong, die ook wel Samatadjia ri Oedjoeng-montjong werd genoemd. Een van zijn volgelingen trof op aanwijzing van zijn jachthond in een boschje een beeldschoone jonge vrouw aan. Hij deelde dit aan Karaëng Paoerang mede, die door nieuwsgierigheid gedreven het boschje binnenging. Daar vond hij echter slechts een nagel en wat menschenhaar. Verder zoekende vond hij een koker van ,bamboe patoeng”, waaruit menschenhaar van dezelfde kleur stak. Hij riep toen uit: „Indien zich in dezen bamboekoker iemand bevindt, zoo komt hij daaruit te voorschijn. Anders kap ik den koker door."

Nauwelijks had hij deze woorden uitgesproken of een mooie jonge vrouw trad uit den koker te voorschijn. $\mathrm{Zij}$ noemde zich Banri Manoeroeng en verklaarde uit den hemel te zijn nedergedaald. Karaëng Paoerang vroeg haar onmiddellijk ten huwelijk, waarin zij toestemde. Toen Karaëng Kalimporo hiervan hoorde liet hij Karaëng Paoerang weten, dat hij een groot huwelijksfeest ter eere van hem en Banri Manoeroeng wilde geven. Deze laatste ried Karaëng Paoerang aan, de uitnoodiging van Karaëng Kalimporo aan te nemen en maar alvast vooruit te gaan; op den 7 den dag moest hij haar komen halen. Aldus werd besloten. Toen Karaëng Paoerang op den bepaalden dag bij zijn bruid terug was, maakte hij zich er over bezorgd, dat zij geen volgelingen hadden om hen naar Kalimporo te geleiden. Banri Manoeroeng stelde hem echter gerust en zeide, dat zij daarvoor wel zorgen zou. Meteen maakte zij haar haren nat en besprenkelde met het vocht, dat daarvan afdroop, een groot aantal ,bamboe patoengs", waaruit weldra mannen te voorschijn traden. Daarna besprenkelde zij met hetzelfde vocht verschillende grashalmen, waaruit onmiddellijk vrouwen voor den dag kwamen. Met het uit deze mannen en vrouwen bestaand gevolg begaven zij zich naar Kalimporo, waar zij door den Karaëng-Lowé feestelijk werden ontvangen. Al heel spoedig bemerkte Banri Manoeroeng, dat haar gastheer op haar verliefd werd. Zonder haar bevinding aan Karaëng Paoerang mede te deelen, wist zij dezen over te halen met haar te vertrekken. $Z$ ij vestigden zich te Bangkala, niet ver van de nederzetting Oedjoeng-montjong.

De Samatadji van Oedjoeng-Montjong en de Karé van Patiro stelden zich met hur onderhoorigen onmiddellijk ter beschikking van Karaëng Paoerang en zijn gade, die zij tot Karaëng van Bangkala uitriepen en steunden in den strijj, welke kort daarop tegen Kalimporo ontbrandde, omdat de Karaëng-Lowé hiervan Banri Manoe- 
roeng had opgeëischt en Karaëng Paoerang dien eisch had afgewezen."

Zooals ik reeds zeide, treft men deze mythen door geheel ZuidCelebes, hier meer daar minder, aan.

II.

In Hoofdstuk I merkte ik op, dat wij in de hoofdengeslachten dezelfde verhoudingen als in de vorstengeslachten, doch in eenvoudiger vorm, terugvinden. Men spreekt - schreef ik - ook bij de weinige hoofdengeslachten, die zich zelf nog op peil hebben weten te houden, van „Ana'-tino" ", „Ana'-sipoewé” en „Ana'-tjera”," 1 ). Dit geldt niet alleen voor Gowa, doch voor het geheele Boegineesche en Makassaarsche gebied en treedt vooral duidelijk aan den dag wanneer een hoofd overleden is, en de opvolging ter sprake wordt gebracht. Dan worden als vanzelf die leden van het hoofdengeslacht naar voren geschoven, die van zuiver bloed zijn en diegenen die, om den Gowaschen term te gebruiken, ,,ana'-sipoewé” zijn, vallen vanzelf af.

Als wij eenig inzicht in de erfopvolging in de hoofdengeslachten willen verkrịgen, staan wij voor grootere moeilijkheden dan ten aanzien van de successie in de vorstelijke waardigheid. De gegevens, die wij bezitten laten althans niet toe, dat wij lijsten van de opeenvolgende hoofden van deze of gene gemeenschap kunnen samenstellen in den trant van de lijst der Gowasche vorsten. Toch bestaat er alle reden om aan te nemen, dat de successie in de hoofdengeslachten van het Makassaarsche gebied vrijwel gelijk is geweest aan die welke wij constateerden in het Gowasche vorstenhuis, in de Boegineesche landen de erfopvolging in de hoofdengeslachten dezelfde kenmerken toonde, als die in het Bonesche vorstengeslacht.

In de Makassaarsche overleveringen zien wij, zonder dat dit overigens uitdrukkelijk vermeld wordt, steeds den „Ana'-tino”'-zoon den vader opvolgen. Het hoofd wijst nu eens zijn opvolger aan, dan weer wordt deze verkozen door de kiesheeren of onderhoorigen. Nog heden ten dage kan men bij de Makassaren de verknochtheid aan dit stelsel steeds weer opnieuw vaststellen. Hoeveel er ook in den loop der tijden is veranderd, hoeveel oude hoofdengeslachten gevallen en hoeveel nieuwe gekomen zijn, hoeveel organisch gegroeide gemeenschap-

1) Blz. 456 . 
pen verkaveld en hoeveel nieuwe er gecreëerd zijn, het patrilineale erfopvolgingsstelsel leeft. Sterft het eerste hoofd van een splinternieuwe, door het Europeesch bestuur gemaakte, gemeenschap, dan spreekt het voor de lagere hoofden vanzelf, dat de oudste zoon van het overleden hoofd het eerst in aanmerking komt. Deugt deze niet of voelt hij er niet voor - hij kan, bijvoorbeeld, wat nogal eens voorkomt, handelaar zijn en een ruime bron van inkomsten niet willen verwisselen voor eer en een kleine bezoldiging - dan zullen de hoofden ongetwijfeld den tweeden zoon verkiezen. Had het hoofd geen zoons, dan zal men waarschijnlijk bij zijn broeders of diens zonen rondzien.

Is een geslacht op een of andere wijze ten val gekomen en wordt een vreemdeling door het Gouvernement op den hoofdenzetel geplaatst, dan zullen bij volgende verkiezingen steeds weer de leden van het verdreven hoofdengeslacht opduiken en aanhang verwerven onder de lagere hoofden. En steeds zullen de candidaten zoons of kleinzoons van de oude hoofden zijn. Mij is geen beter voorbeeld van het einde van een hoofdengeslacht bekend dan dat van de Gallarranggeslachten van Mangasa, Boronglowé en Songkolo'. In 1868 smeedde de toenmalige Gallarrang van Mangasa, Manjereang daëng Serang, tezamen met den Gallarrang van Songkolo', Garantjing daëng Malala alias Bapa Ponto en diens zoon, den Gallarrang van Boronglowé, Apabang, een complot om Karaëng Borong, den regent van Tanralili, op den troon van Gowa te helpen, daar zij van meening waren, dat deze, als lijnrechte afstammeling van Sangkilang, en niet I Koemala, de regeerende vorst, recht had op de koninklijke waardigheid in Gowa ${ }^{1}$ ). De drie Gallarrangs werden tot aan hun dood door I Koemala in de gevangenis opgesloten. Songkolo' werd als zelfstandig gebied opgeheven, daar de Gallarrang van Songkolo', de oudste zijnde, als de voornaamste aanstoker van den opstand werd beschouwd, en bij Boronglowé gevoegd. Ten slotte werd door den vorst van Gowa en zijn rijksraad bepaald, dat de afstammelingen van de drie opstandige Gallarrangs tot in het zevende geslacht geen enkele functie zouden mogen bekleeden. Dit is nu nog in heel Gowa bekend, en bij verkiezingen is men thans nog dit verbod indachtig.

Zagen wij in de Makassaarsche landen, bij de erfopvolging der hoofdengeslachten dezelfde elementen als in het successiestelsel van het Gowasche vorstenhuis, in de Boegineesche streken herkennen wij

1) Deze gebeurtenis kwam reeds in ander verband in het vorige hoofdstuk ter sprake. Zie blz. 492, 499 en 500.

D1. 90. 
zonder moeite allerwegen het Bonesche systeem, zoowel in de overleveringen als in de hedendaagsche verkiezingen.

III.

Ten opzichte van de waardigheden, welke door de leden van de hoofdengeslachten kunnen worden bekleed, kan ik kort zijn. De waardigheid van Karaëng van Manoedjoe bijvoorbeeld is in beginsel slechts weggelegd voor een ,ana'-tino"'-man uit het hoofdengeslacht van Manoedjoe en zoo is het ook in Borisallo, in Malewang, in Maroesoe' en in Segeri. De waardigheid van Aroe van Tempe behoort in beginsel slechts over te gaan op een ,ana'-matola”, man of vrouw, uit het hoofdengeslacht van Tempe en in Bola, Timoeroeng, Sailong, Ponre, Kahoe, Mario-ri-Wawo of Larompong is het niet anders.

Een waardigheid in eigen gemeenschap, vaak bekleed door een lid van het hoofdengeslacht is, vooral in de Boegineesche, minder in de echt Makassaarsche landen, en in beide gevallen slechts in samengestelde gemeenschappen, het „Soellewatangschap”, een waardigheid, die het best vergeleken kan worden met het rijksbestierderschap in de groote rijken. „Soellewatang” beteekent ,plaatsvervanger”, welke naam zeer juist is, daar de "Soellewatang" in de plaats treedt van het eigenlijke hoofd en het dagelijksch bestuur voert. Soms wordt deze functie bekleed door een lid van een hoofdengeslacht, dat lager in rang is, en dat het bewind voert over een van de samenstellende deelen van de gemeenschap, waaraan het den "Soellewatang” pleegt te leveren. In de Boegineesche landen beteekent „Soellewatang” vaak "stedehouder" en de functie is dan in wezen een andere dan de vorenomschrevene. De vorst van Bone, bijvoorbeeld, lijfde soms gebieden bij zijn rijk in, handhaafde desondanks, of verjoeg de geslachten, die daarover het bewind voerden en stelde daarvoor in de plaats „Soellewatangs” aan. Deze „Soellewatangs” waren dan meestal ò lid van het geslacht, dat tot dusver over het gebied" had geregeerd òf lid van een ongeveer even hoog geslacht.

Een vrouw kan, voorzoover ik het weet, ook in de Boegineesche landen, nimmer "Soellewatang” worden. Het „Soellewatangschap” is in de eerste plaats een practische bestuursinstelling, vandaar vermoedelijk dat vrouwen uit deze functie werden en worden geweerd.

Voor de hoofdengeslachten zijn ook functies op een hooger dan het locale plan weggelegd. Ik denk hierbij aan de „Aroempitoe”, de 
zeven „Aroe's” van Bone, de „Batesalapang”, de negen „,bate's” of vaandels, van Gowa, en al de andere rijksraden in de groote rijken van Zuid-Celebes. Voorts zag men dikwijls leden van hoofdengeslachten hooge functies in de vorstelijke legers bekleeden.

IV.

De hoofdengeslachten verhouden zich tot de regalia, die bij de gemeenschappen waarover deze geslachten regeeren behooren, op dezelfde wijze als de vorstengeslachten dit doen tot de rijkssieraden der rijken. $\mathrm{Na}$ de uitvoerige behandeling van dit onderwerp in het voorgaande hoofdstuk kan ik met deze vermelding volstaan.

V.

„Aroe” of „Aroeng” en „Karaëng” zijn de meest voorkomende titels, respectievelijk in de Boegineesche en in de Makassaarsche landen. Voorts, alleen in de Makassaarsche landen, "Gallarrang”. of „Galla”, een titel, die onder den „Karaëng”-titel staat. In de Makassaarsche overleveringen vinden wij steeds weer terug, als oudste titel „Dampang”, dan „Kare”, „Karaëng Lowé”; voorts de titels van „Malela”, „Poenggaoe”, „Limpo”, „Ratoe”, „Batara” en „Lao”. „Lomo" is een nog zeldzaam voorkomende titel. Over oude titels in andere streken ontbreken mij gegevens. In het Mandarsche, waar de geheele titulatuur afwijkt van het overige Boegineesche gebied, is een veel voorkomende titel „Papoeangang”.

De „Daëng”-titel, die reeds besproken werd bij de afzonderlijke behandeling der zuivere vorstentelgen en de tusschenstanden, treft men in de hoofdengeslachten algemeen aan. Honoraire „Karaëng”titels evenwel niet.

\section{VI.}

De vrijen.

Naar reeds gebleken zal zijn worden in de hoofdstukken, die de standen afzonderlijk behandelen geen afgeronde karakteristieken der standen gegeven, doch essentieele kenmerken, die min of meer een aparte behandeling vragen en verdragen, besproken.

Ten aanzien van de afstamming der vrijen zij opgemerkt, dat hieromtrent geen mythen bestaan, zooals wij die zoowel bij de vorstenals bij de hoofdengeslachten leerden kennen. 
Een erfopvolgingsstelsel als wij in deze geslachten ten opzichte van de vorstelijke waardigheid en de hoofdenfunctie aantroffen, bestaat voor de ambten en beroepen der vrijen niet. Wel treffen wij hier en daar, zoowel in de Boegineesche als in de Makassaarsche gebieden, een facultatieve patrilineale successie aan. Dit wil zeggen, dat wij den zoon van een visscher meestal visscher zien worden, doch niet altijd. Een voorbeeld van een landbouwerszoon, die naar de kust trok en ter vischvangst toog, is mij niet bekend en behoort mijns inziens tot de onwaarschijnlijkheden. Een songko'-vlechter leidt evenwel den zoon van een bevrienden landbouwer niet minder gaarne in zijn vak op dan zijn eigen zoon. In het overzicht der door vrijen bekleede waardigheden en uitgeoefende beroepen, dat ik hieronder geef, zal ik deze facultatieve patrilineale successie met het teeken $\triangle$ aangeven.

Wij zagen, welke waardigheden slechts weggelegd waren voor den hoogsten stand, de tusschenstanden en de hoofdengeslachten. Als wij op de vraag: welke waardigheden, ambten en beroepen dan inhaerent zijn aan den stand der vrijen, antwoorden: alle andere, dan hebben wij gelijk, doch zijn daarbij zeer onduidelijk. Daarom volge hier een lijst van de voornaamste waardigheden, ambten en beroepen, die door de vrijen bekleed en uitgeoefend worden.

Daarin wordt onder No. 8 het beroep van landbouwer genoemd. $\mathrm{Nu}$ dient men daarbij echter onmiddellijk te bedenken, dat de meeste andere beroepen slechts voorkomen als nevenberoepen van het beroep van landbouwer, zoodat de landbouw dus het hoofdmiddel van bestaan blijft. Vrijwel een ieder is landbouwer. Overal treft men in Zuid-Celebes den sterken drang aan, rijst en mais, in het algemeen de voedingsgewassen dus, op eigen grond te telen. In het overzicht plaats ik bij de nevenberoepen het teeken §. Dit teeken wil dus zeggen, dat het beroep van scheepsbouwer over het algemeen sawahbezit en sawahbewerking door den scheepsbouwer zelf, insluit. Het wil zeggen, dat de „,dodja”, de koster van een moskee, of de „sanro”, de priester van de kleine gemeenschappen, evenals vrijwel alle andere mannelijke dorpsgenooten bij het begin van den regentijd zijn sawahs gaat bewerken. En zoo doen ook wel de scheepskapitein en de matroos. Het wil nict zeggen, dat een matroos, een zoutmaker of een visscher altijd landbouwer moet zijn.

1. Priester.

(,bissoe”, [Boeg., Mak.] ; „sanro”, [Boeg.] $\triangle \S$; ,pinati” [Boeg., Mak.] $\triangle \S$. Van deze priesters waren de „,bissoe's” 
de voornaamste. Met den val van de vorstenhoven van Gowa en Bone zijn ook deze „bissoe's" vrijwel van het tooneel verdwenen. $Z$ ij vervulden de belangrijkste rol bij het ceremonieel, dat verbonden was aan de rijkssieraden en verleenden hun intermediair in het verkeer van aanzienlijken naar bloed en goed - de kosten waren hoog - met goden en geesten. De hooge Mohammedaansche godsdienstbeambten hebben door een, meestal ondergrondschen strijd, aan den invloed der „bissoe's” veel afbreuk gedaan. De ,bissoe's” waren meestal mannen, doch ook wel vrouwen. De mannen waren als vrouw gekleed en gedroegen zich als vrouwen. $\mathrm{Zij}$ waren, naar men moet aannemen, allen homosexueel. Zij waren afkomstig uit den stand der vrijen. $Z$ ij leidden knapen voor het ,bissoe"-schap op. Het waren knapen, die reeds als kind aan meisjes deden denken. De ,bissoe's” waren ongehuwd en leefden met elkander of ook wel met, in de oogen der Boegineezen en Makassaren, normale mannen. Zij hadden toegang tot de vrouwenvertrekken. Onder bestuursambtenaren op Zuid-Celebes kan men vaak vernemen, dat alle „bissoe's” hermaphroditen zijn. Herhaalde medische onderzoekingen hebben evenwel uitgewezen, dat zij physiek tot de mannen behoorden ${ }^{1}$ ).

De ,sanro's” en ,pinati's” vinden wij nog overal. In de Boegineesche landen zijn het zoowel mannen als vrouwen. Men ziet dan een facultatieve bilaterale successie. Soms ook zijn het ,wandoe's”, homosexueelen, als vrouw gekleede en zich gedragende mannen. In de Makassaarsche landen trof ik altijd mannen. $Z_{\mathrm{ij}}$ verrichten het ritueel voor de regalia van de kleine gemeenschappen. Zij leiden de Boegineezen en Makassaren door het leven en verleenen hun steun in alle phasen van het menschelijk bestaan als geboorte, besnijdenis, tandenvijlen, huwelijk, overlijden en begrafenis, alsook in alle stadia van den rijst- en maisbouw. Vooral in de bergstreken is hun invloed nog zeer groot. Zij zijn allerminst alleen dokter of dokteres zooals Matthes in zijn beide woordenboeken vermeldt, al is het voorkomen en genezen van ziekten voor hen een goede bron van inkomsten.

1) Matthes wijdde een uitvoerige verhandeling aan de Bissoe's, doch beperkte zich in hoofdzaak - jammer genoeg - tot de door hen verrichte ceremoniën, met uitzondering van het ritueel verbonden aan de regalia. Verh. Kon. A. v. W., afd. Letterk., dl. 7 (1872). 
2. Onderhoofd. $\S$.

(,Matowa”, „Kapala”, „Soellewatang”, [Boeg. en Mak.] ; „Anregoeroe” [Boeg.] ; „Daëng”, „Anronggoeroe”, ,Galla'”, „Gallarrang” [Mak.], enz.) De onderhoofden zijn schakels tusschen de hoofden en hun onderdanen. Zij ontleenen hun gezag aan het hoofd, dat boven hen staat. Hun gezag is een afgeleid gezag. Het achttal titels, dat hierboven werd vermeld, is niet meer dan een greep van de meest voorkomende uit tientallen. Ik acht het niet onmogelijk, dat mijn aanduiding van de taal, waarin de een of andere titel voorkomt, in zooverre correctie kan verwachten, dat later kan blijken, dat deze titel niet alleen in de Makassaarsch-sprekende, doch ook in de Boegineesch-sprekende landen voorkomt, of omgekeerd. Ik vermeld, wat ik zelf vond.

3. Helper van hoofd of onderhoofd. . (,soero” [Boeg.], ,sareang” [Mak.]).

4. Lagere Mohamedaansche godsdienstbeambten. $\S$ (,katte” [Boeg. en Mak.], „dotja” [Boeg.], ,dodja" [Mak.], „bidala” [Mak.], ,bilala” [Boeg.]). De „katte” is de prediker, de „dodja” of „dotja” de koster of portier van de moskee en de ,bidala" of ,bilala” is de oproeper tot het gebed.

5. Danseres.

(,padjoge" " [Boeg.], ,pakarena” [Mak.]). Er zijn verschillende soorten danseressen. In de Boegineesche landen kent men de „padjoge's”, de danseressen, meestal volwassen jonge vrouwen, die tegen betaling op feesten komen dansen en vaak geprostitueerden zijn, - in de Makassaarsche landen de ,pakarena's”, onvolwassen meisjes, over het algemeen uit den stand der aanzienlijke vrijen; zij worden streng bewaakt door hun leider - zij dansen als de ,padjoge's" in troepen - den „Anronggoeroe pakarena", en door oude vrouwelijke familieleden. $Z \mathrm{Zij}$ dansen eveneens op feesten, doch de door haar uitgevoerde dansen zijn van anderen aard dan die der ,padjoge's".

6. Ta mboer. $\S . \triangle$.

(,paganrĕng” [Boeg.], „paganrang” [Mak.]). De tamboers, die op geen feest mogen ontbreken, zijn lieden van aanzien in de Makassaarsch-Boegineesche maatschappij. 
Hun beroep is zeer moeilijk te leeren, daar het goed bespelen der trommen een groote kunst is. Soms gaat het beroep over van vader op zoon, soms heeft een tamboer leerlingen.

7. Verteller. .

(,,pakeso-keso” (Boeg. en Mak.)). De vertellers, de ,,pakesokeso", die het land doorkruisen met hun „keso-keso”, hun primitieve viool, en de oude heldendichten voordragen, zijn op alle feesten zeer geziene gasten. Ook hier treft men soms leerlingen, die de vertelkunst willen leeren van een befaamden verteller.

8. Landbouwer.

(,pakoko”, ,pagaloeng” [Boeg. en Mak.] ,padarě”, ,palaonroema” [Boeg.], ,paboeboelang” [Mak.]).

9. Zoutwinner. $\S$. $\triangle$.

(,papedjé” [Boeg.], ,patjéla” [Mak.]).

10. Arensuikerkoker. $\S$. $\triangle$.

(,pagolla” [Boeg. en Mak.]).

11. Visscher. $\S$. $\triangle$.

(,padjala” [Boeg. en Mak.], ,pakadja” [Boeg.], ,pabanrong" [Boeg.]). Een algemeene naam voor iemand, die in het grootste gedeelte van zijn levensonderhoud voorziet door het vangen van visch, kent noch de Makassaar, noch de Boeginees. Er zijn voor zout- en zoetwatervisscherij tientallen netten en fuiken, hengels en scheppen in gebruik, en van ieder soort gereedschap is weer een naam voor dengeen, die het gebruikt, afgeleid. De visschers wonen meestal in afzonderlijke dorpen. $\mathrm{Zij}$ huwen meestal binnen hun groep. De „Tobadjo's”, die in het algemeen gesproken immer op hun schepen leven of verblijf houden in hutjes van tijdelijken aard langs de kusten, vaak temidden der rizophoren, zijn nog onvoldoende bestudeerd.

12. Scheepsbouwer. $\S$. $\triangle$.

(,panrita biseyang” [Mak.], ,panrita lopi” [Boeg.]). Hier is bedoeld de overal voorkomende scheepsbouwer van kleine vaartuigen. De groepen der scheepsbouwers in Tiro en Lemo-lemo in Kadjang, aan de Zuidkust, en andere centra. zijn nadere bestudeering overwaard. 
13. Nettenmaker. $\S$.

De nettenmaker, die zijn naam ontleend aan de soort van netten, die hij maakt, is bovendien visscher.

14. Grof s mid (?).

(,palanro-běssi”, „panre-bĕssi” [Boeg.], „padede-bassi”, „panre-bassi” [Mak.]). Voorzoover mij bekend is, zijn alle smeden rondreizende Sidenrengers. Meermalen heb ik hen aan het werk gezien in een tijdelijke loods ergens in Gowa of in Bone. Zij blijven zoolang er werk is; is dit gedaan dan trekken zij weer verder. Noch in Bone, noch in Gowa, Bantaëng of Polombangkeng, noch in het land van Maros of Sindjai heb ik ooit een dorpssmidse aangetroffen. - De tweede vorst van Bone was bijgenaamd ,de smid”.

15. Goudsmid. $\S$. $\triangle$.

(,palanro-oelawĕng” [Boeg.], ,padede boelaëng” [Mak.]). Dit beroep wordt ook wel door voorname edellieden uitgeoefend. Het staat hoog in aanzien.

16. $\mathrm{Z}$ w a a rdveger. $\S$.

(,pagoelinra” [Boeg.], ,pagoerinda” [Mak.]). De wapenslijpers reizen met hun slijpsteen rond.

17. B ouw meester. $\S$. $\triangle$.

(,panrita-bola” [Boeg.], „panrita-balla” [Mak.]). Vooral vroeger bouwde een ieder, met behulp van zijn dorpsgenooten, zijn eigen huis. Voor grootere huizen riep en roept men echter de hulp in van een ,panrita-bola” of ,panrita-balla”. Deze geeft niet alleen leiding, voorzoover het het technische gedeelte van den bouw betreft, doch ook ten aanzien van gunstige en ongunstige dagen, van goede of slechte plaats om te bouwen en nog meer dergelijke zaken, is hij de aangewezen persoon om regelend op te treden.

18. Timmerman. $\S$.

(,panre-adjoe” [Boeg.], ,panre-kayoe" [Mak.]).

19. H o uts n ij d e r. §.

(,paöekiri”, [Mak. en Boeg.]).

20. Touwslager. $\S$. $\triangle$.

(,patoeloe" [Boeg.], ,paötere" [Mak.]).

21. Potten bakster (?).

(..padede-oering” [Mak.], ,palanro-oering” [Boeg.]). Ik 
zelf heb slechts pottenbaksters gezien; er zijn er zeer weinig. Matthes spreekt echter in zijn beide woordenboeken over ,pottenbakkers".

22. Vrachtzadelmaker. §. $\triangle$.

(,papalana” [Mak.], ,pasappe” [Boeg.]).

23. Mandenvlechter (-vlechtster). §. $\triangle$.

(,pabakoe” [Boeg. en Mak.]). Behalve ,pabakoe” bestaan er nog meer namen, alle ontleend aan een van de vele soorten manden. De mannen maken manden van zwaarder materiaal, de vrouwen van licht materiaal.

24. Mattenvlechter. $\S$. $\triangle$.

(,padjali”, [Boeg. en Mak.]). Iedere soort mat geeft weer aan dengeen, die haar maakt een afzonderlijken naam).

25. Songko'-vlechter. $\S$. $\triangle$.

(,pasongko'" [Boeg. en Mak.]).

26. Alami-vlechtster.

Volledigheidshalve wordt deze bezigheid van adellijke vrouwen, het maken van zeer mooie mandjes van uiterst fijn gespleten orchideeënstengels, in dit overzicht opgenomen.

27. Handelaar. $\S . \triangle$.

(,pasoedagara” [Boeg. en Mak.], ,padangkang” [Boeg.], ,padanggang" [Mak.]).

28. Scheepskapitein. $\S . \triangle$.

(,anakoda” [Boeg. en Mak.]). Deze ,anakoda's” zijn meestal ook handelaar, die hun vracht verhandelen.

29. Matroos. $\S$. $\triangle$.

(,sawi” [Boeg. en Mak.]). Ook deze ,sawi's” zijn meestal handelaars, die belang hebben bij de vracht van het schip, waarop zij dienen. Deze zeevaarders en vooral de ,anakoda's" vormen een afzonderlijke groep, die over het algemeen in hoog aanzien staat. Zij bewonen aparte dorpen aan de kust of aan zeearmen. $\mathrm{Zij}$ huwen bij voorkeur in de eigen groep.

Moderne beroepen als die van metselaar, verver, chauffeur, koeli en politieagent laat ik buiten bespreking. 
Wij zagen, dat een ieder vrijwel den landbouw uitoefent als hoofdmiddel van bestaan, dat een ieder, met behulp van de mannelijke leden der gemeenschap, zijn eigen huis bouwt - zoo wij de aanzienlijken naar goed en bloed uitschakelen -; ook de zorg voor lichaamsbedekking is grootendeels nog het werk van het eigen gezin en wel van de vrouwen. Deze spinnen, verven het garen en weven. Het gebruik van ingevoerde garens en het koopen van gemaakte kleeren nam evenwel, voornamelijk in de omgeving van grootere plaatsen, langzaam toe.

\section{VII.}

De vrijen vormen de groote massa der bevolking. $Z \mathrm{ij}$ zijn vrij in zooverre, dat zij rechten bezitten. Deze rechten kwamen zeker, en komen nog wel eens, tegenover den adel in het gedrang - zooals wij in het volgende hoofdstuk zullen zien - doch in wezen bezaten en bezitten zij dezelfde rechten op grond en water als de adel. De vrijen bezaten bovendien een soort van kiesrecht ten aanzien van de boven hen gestelde hoofden, waarover in het volgende hoofdstuk nader. $\mathrm{Zij}$ hadden in beginsel het klachtrecht tegenover den adel; dat zij en een ieder het tegenwoordig hebben, spreekt vanzelf. In het volgend hoofdstuk zal het duidelijk worden, dat ook van dit klachtrecht vaak weinig terecht kwam, doch dit was dan ook in de oogen van den Boeginees en den Makassaar een uitvloeisel van misbruik van macht van de zijde der edellieden.

Tegenover deze rechten stonden verplichtingen. Een deel dezer verplichtingen wordt door Makassaar en Boeginees met hetzelfde woord aangeduid: ,kasoewiyang”. Hoewel deze verplichtingen zeer wel in het volgend hoofdstuk, dat de verhouding der verschillende standen onderling tot onderwerp zal hebben, behandeld zouden kunnen worden, geef ik er de voorkeur aan dit reeds hier te doen, daar de verplichtingen, die ,kasoewiyang” worden genoemd, kenmerkend zijn voor den stand der vrijen. De adel immers kent - zooals wij zoo aanstonds zullen zien - een ,kasoewiyang” in uiterst beperkten zin, terwijl de slaven in het geheel geen ,kasoewiyang" kunnen verrichten.

Doch laat ons trachten het „kasoewiyang”-begrip eerst te leeren kennen.

Het is van alle schrijvers eigenlijk alleen Kooreman, die aan dit voor Zuid-Celebes zoo belangrijke onderwerp ruime aandacht schenkt. Tot een scherpe omlijning van het begrip komt hij echter niet. Daar 
hij zeer positieve mededeelingen doet, is het voor mij onontbeerlijk hem hier te citeeren.

Kooreman dan schrijft ${ }^{1}$ ): „Zoodra de ontginning (van een stuk woesten grond) is voltooid, dat is, zoodra de grond beplant is, verkrijgt de ontginner daar het recht van erfelijk vruchtgebruik. Dat recht verliest hij alleen in het geval hij niet naar behooren aan zijn kasoewyang voldoet.

Gewoonlijk verstaat men onder kasoewyang heerendienst; beter is het dat woord door verplichtingen te vertalen, want men spreekt niet alleen van kasoewyang van de hoofden, zelfs van de karaengs en anakaraengs, en wordt daaraan niet voldaan, dan kan aan elk der genoemde personen de grond ontnomen worden, waarvan hij het erfelijk vruchtgebruik heeft.

De kasoewyang is verschillend naar den stand van den vruchtgebruiker. In de Vorstenlanden (hiermede bedoelt Kooreman dat gedeelte van Zuid-Celebes, dat in zijn tijd nog niet onder het bewind der Nederlanders was gebracht) verstaat men daaronder al dat gene, waartoe men volgens de adat verplicht is, en al wat de vorst gelieft te bepalen of te eischen, in de Gouvernementslanden bovendien de vanwege het Europeesch gezag gemaakte bepalingen, waaraan men gewoon geraakt is. Van een nieuw voorschrift of verbod zegt de bevolking dan ook: dat is mijn kasoewyang niet; hetzelfde zegt een hoofd of regent, aan wien iets wordt opgedragen, waartoe hij meent niet verplicht te zijn. De belastingschuldige noemt het zijn kasoewyang , dat hij zijn vertiening aan het Gouvernement moet voldoen, de heerendienstplichtige, dat hij aan den weg moet werken, het kamponghoofd, dat hij elken Maandag op het kantoor moet komen, de anakaraeng, dat hij den regent op reis, op de jacht, - vroeger ook ten oorlog - moet vergezellen, de regent, dat hij eens in het jaar ter eere van het ornament een karbouw moet slachten, en den Gouverneur, assistent-resident of controleur op hum inspectiereizen moet vergezellen.

Onder kasoewyang werd vroeger ook begrepen de verplichting om te wonen in het district, waarin de grond was gelegen, waarvan men het erfelijk vruchtgebruik genoot. Dit verklaart het algemeen geldend gebruik om de gronden verbeurd te verklaren van misdadigers, die zich door de vlucht aan straf onttrekken. Tegenwoordig moet de vruchtgebruiker of zelf in het district wonen, of ten genoegen van

1) „Feitelijke toestand enz.”, Ind. Gids, 1883, II, blz. 152 en 153. 
het betrokken districtshoofd een in het district woonachtigen vervanger stellen, die op zich neemt de aan den grond verbonden kasoewyang te presteeren. Wordt daaraan niet voldaan, dan komt de grond weder ter beschikking van het district."

Tevoren had Kooreman reeds gezegd ${ }^{1}$ ): „Zij (vreemdelingen) hebben eenvoudig vergunning tot vestiging te vragen aan het betrokken districtshoofd, wien zij te gelijk een klein geschenk aanbieden, en zeer zelden wordt die vergunning geweigerd. De vergunning tot vestiging sluit in zich de verplichting tot het presteeren van de kasoewyang zooals die voor de leden van het district zijn geregeld, en het recht tot het ontginnen van woeste gronden. Het is echter gebruikelijk, dat zij ook vergunning tot de ontginning vragen, vermoedeliik om te voorkomen, dat hun keus valt op gronden, waarop anderen rechten kunnen doen gelden.

Zelfs zonder vestiging kunnen vreemdelingen de vergunning erlangen tot het ontginnen van woeste gronden, als zij ten genoegen van het betrokken hoofd een in het district woonachtig persoon aanwijzen, die op zich neemt aan de kasoewyang te voldoen."

Iets verder lezen wij ${ }^{2}$ ): „Van den overgang van grond zoowel op leden als op niet-leden van het district, moet aan het districtshoofd worden kennisgegeven, die daardoor getuige der handeling wordt, en in de gelegenheid is de aan den grond verbonden kasoewyang te regelen. Hij kan den overgang verbieden als hij vermoedt, dat door den nieuwen vruchtgebruiker of diens vervanger daaraan niet naar behooren voldaan zal worden. Het hoofd maakt echter hoogst zelden van dit recht gebruik."

Voorts verklaart Kooreman ${ }^{3}$ ): ,Algemeen geldt de regel, dat iemand, die het vruchtgebruik van gronden heeft, en nalatig is in het voldoen van zijn schulden, gedwongen kan worden om ò zijn recht te verpanden en met de pandsom zijn schulden te voldoen, òf zijn recht in pand af te staan aan zijn schuldeischer. Op grond van dit gebruik, dat van veelvuldige toepassing is, zou men het voldoen van schulden ook al tot de kasoewyang kunnen rekenen."

Ook zij nog het volgende geciteerd $\left.{ }^{4}\right)$ : ,Als door het niet voldoen van de kasoewyang het vruchtgebruik van gronden wordt verbeurd, blijven de aanplantingen strikt genomen het eigendom van den ge-

1) Blz. 150, t.a.p.

2) Blz. 155, t.a.p.

3) Blz. 157, t.a.p.

4) Blz. 158, t.a.p. 
wezen vruchtgebruiker. Gewoonlijk wordt hij gelast ze te verkoopen, en hieraan wordt bijna altijd voldaan, omdat hem met het ontnemen van zijn grond tevens het verblijf in het district wordt ontzegd, ten minste onmogelijk gemaakt. Het ligt echter voor de hand, dat onder het willekeurig vorstenbestuur - een enkele maal ook door regenten - met den grond ook de aanplantingen worden verbeurd."

Tenslotte nog deze aanhaling $\left.{ }^{1}\right)$ : „Daar de kasoewyang verbonden is aan het vruchtgebruik van grond, behoort de kooper daarvan te zijn vrijgesteld. Dit is echter alleen het geval als de koop slechts een gering aantal boomen betreft; wordt een groot aantal verkocht dan is de kooper tot kasoewyang verplicht."

De voornaamste gevolgtrekkingen, die wij, aan de hand van de uiteenzetting van Kooreman voorloopig kunnen maken zijn de volgende:

(1). Het woord ,kasoewiyang” is het best door verplichtingen te vertalen; (2) niet alleen de kleine luiden, ook de hoofden, zelfs karaengs en anakaraengs waren aan deze verplichtingen onderworpen; (3) deze verplichtingen waren onverbrekelijk verbonden aan den grond, waarvan de kleine luiden, de hoofden, de karaengs of de anakaraengs het erfelijk vruchtgebruik hadden; (4) deze verplichtingen zijn verschillend naar den stand van den vruchtgebruiker; (5) in de vorstenlanden verstond men ten tijde van Kooreman onder ,,kasoewiyang" al datgene, waartoe men volgens de adat verplicht was, en al wat de vorst geliefde te bepalen of te eischen, in de Gouvernementslanden bovendien vanwege het Europeesch gezag gemaakte bepalingen, waaraan men gewoon geraakt was; (6) het recht van vruchtgebruik gaat alleen verloren ingeval de vruchtgebruiker niet naar behooren aan zijn ,kkasoewiyang” voldoet.

Het is duidelijk, dat zonder aanduiding, waarin deze verplichtingen nu eigenlijk bestaan, het begrip ,kasoewiyang” met het bovenstaande allerminst is bepaald.

Hieronder zal ik trachten tot een zoo nauwkeurig mogelijke bepaling van het begrip „kasoewiyang” te komen, eensdeels en voornamelijk aan de hand van door mij zelf verzamelde gegevens en andersdeels gebruikmakende van mededeelingen van anderen.

Eén ding dienen wij daarbij niet uit het oog te verliezen en wel dit: dat het heden ten dage na zooveel verandering in de laatste vijfentwintig jaren, heel wat bezwaarlijker moet zijn om behoorlijk materiaal te verkrijgen, dan in de dagen van Kooreman, omstreeks

1) Blz. 158, t.a.p. 
1880. Daarom is het zoo te betreuren, dat Kooreman zoo weinig feiten geeft en zooveel, waarvan men goed beschouwd moet aannemen, dat het eigen meeningen en gevolgtrekkingen zijn.

Ik verdeel het materiaal in eenige groepen, om daarna tot nadere toelichting en beschouwing over te gaan. Zooals te doen gebruikelijk, vermeld ik bij niet van mijzelf afkomstige gegevens steeds uitdrukkelijk den naam van den berichtgever.

Eerste groep.

(De gegevens voor deze groep gelden voor heel het Boegineesche en Makassaarsche gebied. Zij betreffen den toestand zooals deze was in de Vorstenlanden vóór 1906).

(1). De vorsten, de rijksgrooten en de hoofden bezaten domeingronden. Deze domeingronden werden bewerkt, beploegd, beplant en geoogst door vrijen. Zij vervoerden ook de rijst van het veld naar het huis van vorst, rijksgroote of hoofd. De bezitters der domeingronden behoorden tijdens het werk op de domeingronden eten te verschaffen. $\mathrm{Na}$ den oogst behoorden diegenen, mannen en vrouwen, die medegeholpen hadden aan den rijstsnit, bovendien een of meer bossen rijst te ontvangen. Deze lieden woonden over het algemeen in de nabijheid van de domeingronden. $\mathrm{Zij}$ werden meestal vanwege de vorsten of hoofden tot het verrichten van deze diensten opgeroepen door onderhoofden of bepaalde boodschappers. Zoolang de domeingronden nog niet waren bewerkt en beplant, mocht niemand in het gebied van de gemeenschap, waarin de domeingoederen lagen, met het bewerken en beplanten van zijn sawahs beginnen.

(2). Wenschte een vorst, rijksgroote of hoofd een nieuwe woning te laten bouwen, dan kregen onderdanen uit den stand der vrijen in een gebied, waar goed timmerhout voorkwam, bevel een bepaald aantal boomen te vellen. Deze werden dan ter plaatse ruw bekapt en vervolgens naar de plaats vervoerd, waar de woning zou worden opgericht. Het vervoer geschiedde soms door de lieden, die de boomen geveld hadden, soms door vrijen, die in het bijzonder voor het vervoer waren aangewezen. Deze lieden behoefden dan niet altijd den geheelen weg met de boomen af te leggen, doch werden vaak afgelost aan de grens van hun dorp. Op deze wijze werden ook de andere materialen als bamboe, nipablad voor dakbedekking en rotan als bindmiddel, geleverd. Bamboe kwam uit een bamboerijk gebied, nipa uit streken, waar de nipapalm veel voorkwam, en rotan uit de bosschen, die in Z.-Celebes vrijwel alleen nog in de bergstreken bewaard zijn 
gebleven. Meestal waren de materialen afkomstig van domeingronden van vorst, rijksgroote of hoofd. Voor het schoonkappen en gelijk maken van het stuk grond, waarop de woning zou worden gezet, werden evenals voor den eigenlijken bouw van de woning weer andere vrijen, in de nabijheid wonenden, opgeroepen, die dan onder leiding van handwerkslieden de noodige werkzaamheden verrichtten. Zij behoorden door den bouwhec ? van eten te worden voorzien.

(3). Wenschte of behoorde een vorst, rijksgroote of hoofd een feest te geven ter gelegenheid van het schoonmaken der rijkssieraden, een hertenjacht, een adatvischvangst, een huwelijk, een besnijdenis of andere groote gebeurtenis, dan werden vrijen opgeroepen om materiaal te leveren voor feestloodsen, „baroega's”, en deze op te richten. Eten behoorde tijdens het werk door den feestgever te worden verstrekt.

(4). Zoo vorst of hoofd een moskee of een „langgara”, een zeer klein gebedshuis, wilde oprichten, werd daarvoor materiaal en arbeid van de vrijen gevraagd. Door den bouwheer behoorde eten te worden verstrekt.

(5). Voor het herstellen van domeinvischvijvers werden onderdanen van den bezitter, vorst, rijksgroote of hoofd, vrijen, die in de nabijheid der vijvers woonden, opgeroepen.

(6). Begaf een vorst, een rijksgroote, een hoofd zich op reis, dan waren degenen, die de bagage droegen, daartoe opgeroepen vrijen. Soms waren het lieden uit een bepaald dorp, soms verrichtten mannen uit het dorp, dat doorreisd werd, de dragersdiensten. Hadden de hooge reizigers roeiers noodig, dan werden ook deze onder de vrijen opgeroepen. Gedurende de reis behoorden deze lieden door de reizigers van eten te worden voorzien.

(7). Wenschte een vorst of een hoofd een hertenjacht op zijn domeinjachtgronden of een vischvangst te houden, dan werden de omwonende vrijen opgeroepen om ter hertenjacht te drijven en mede te jagen en op het vischfeest de visch in de fuiken te jagen. De opgeroepenen kregen bij een hertenjacht in sommige streken bepaalde aandeelen in de buit. Bij een vischfeest mochten zij behouden, wat zij zelf vingen.

(8). Voor geregelde diensten als wachtdiensten, het halen van water en het halen en kappen van brandhout voor vorst of hoofd, leverden meestal bepaalde dorpen in de omgeving van de residentie lieden uit den stand der vrijen. Hun werd eten verstrekt door vorst of hoofd. 
(9). Voorts werden vrijen opgeroepen voor het aanleggen van versterkingen in tijden van oorlog.

Al deze verplichtingen van de vrijen tegenover de vorsten, hoofden en rijksgrooten heeten overal „kasoewiyang”. De door de adat aan de vorsten, hoofden en rijksgrooten opgelegde verplichtingen om eten, rijst, hertenvleesch en visch aan de ,kasoewiyang”-plichtigen te verstrekken of af te staan, zijn geen ,kasoewiyang”.

Tweede groep.

(Deze gegevens betreffen het Gowasche rijk vóór 1906. In de overige gedeelten van Zuid-Celebes trof men dezelfde soort heffingen aan, zij het onder andere namen en zwaarder of lichter).

(1). In Gowa was het opbrengen van de ,,bilang tana” (lett. ,,grondteller”), een vorstelijke belasting, die één bos rijst per sawah bedroeg, de plicht van iederen sawahbezitter. Deze belasting trof evenwel slechts de vrijen, alhoewel de rijksbestierder in 1891 uitdrukkelijk vaststelde, dat ook de ,ana'-karaëngs” en de hoofden ,bilang-tana” verschuldigd waren.

(2). De ,sima-tammoe-taoeng" ${ }^{1}$ ) was een vorstelijke belasting van 15 duiten, in sommige streken van 10 duiten, die eenmaal 's jaars door alle gehuwde mannen in Gowa moest worden opgebracht. Ook gehuwde slaven moesten deze belasting betalen. Overigens werden slechts de vrijen getroffen. De volksnaam voor deze belasting was door heel Gowa „sima-oering”, de ,rijstepot-belasting”, waarbij het woord ,rijstepot” overdrachtelijk werd gebezigd voor ,gezin”.

(3). Een belasting van dezelfde soort als de „bilang-tana” was de „,singkoeloe-tana”, die in sommige streken door de ,,bilang-tana” verdrongen werd, doch in andere gehandhaafd bleef. $\mathrm{Zij}$ bedroeg 4 bossen rijst voor iedere afgeoogste sawah, dus 1 bos voor iederen hoek of ,singkoeloe”. In Boronglowé bedroeg deze belasting 3 bossen per sawahvak. Ook deze belasting trof slechts den stand der vrijen.

(4). In Malengkeri, Mangasa, Patjinang en Bàlangbaroe, de vier voornaamste rivierplaatsen, werden van alle uitgaande goederen, zelfs van pisangbladeren en dedak, vorstelijke uitvoerrechten geheven. Voorts werd met kracht de hand gehouden aan de vorstelijke heffing

1) „tammoe taoeng” : „tammoe” = rondom, „taoeng” = jaar; de eigenlijke beteekenis zou met ons "verjaardag” weer te geven zijn, volgens Matthes: ,.jaarwende" wellicht? De beteekenis is duister. 
voor vertrekkende schepen, genaamd „soesoeng-bawabinanga", de „,riviermondbelasting”, waarbij vertrekkende Gowasche prauwen slechts belastbaar waren met lading, vreemde prauwen met en ook zonder lading.

(5). Tangalla, in Limboeng, kende de ,laboe-batoe”, lett. „,het zinken der steenen", een ankeragegeld, aldus genaamd naar de steenen, die de Makassaren, en ook de Boegineezen, als ankers gebruiken of ter verzwaring aan hun ankers binden.

(6). Een heffing, die vooral Limboeng en Boronglowé trof, was een recht, dat geheven werd van den ,lasa”'-oogst. In Limboeng werd f 1.- per uitgevoerde mansvracht geheven. In Boronglowé moest iedere opkooper den vorst van Gowa jaarlijks één „risi”, een soort van mand, gevuld met deze vruchten, leveren. Deze heffing werd opgebracht door vrijen.

(7). Het aangeslibde dorp Palaraka moest evenals Songkolo' met zijn dichtgeslibde rivierbedding, voor den vorst een bepaalde hoeveelheid van de op die gronden verbouwde tabak opbrengen, een recht dat „palatta” en ook wel ,,alloe” werd genoemd ,wat allebei aangeslibde grond beteekend. Slechts de vrijen brachten deze heffing op.

(8). In Patalassang diende iedere palmwijn- of „ballo"-tapper tijdens de sawahbewerking volop "ballo" te leveren aan de sawahbewerkers van den vorst. Dit recht heet „Kamisi”, wat „Donderdag” beteekent. Vermoedelijk is dit een gewijzigd „Donderdagsch recht”, dat veel voorkwam in deze landen; zoo Maros met zijn „Kamisi”, dat den karaëng het recht gaf op iederen Donderdag de fuiken te zijnen behoeve te laten lichten. In Borisallo, dat overigens zoo gelukkig is geweest, verschoond te zijn gebleven van alle andere heffingen voor den vorst van Gowa, - als uitvloeisel van een vriendschapsband, die in de overleveringen van Borisallo nog bezongen wordt -, eischte een vervormd Donderdagsch recht, dan ook „,kamisi” geheeten, voor den vorst van Gowa 6 stukken arensuiker van iederen suikerkoker per maand. Deze verplichtingen kwamen ten laste van de vrijen.

(9). In Parigi kende men een vorstelijke heffing genaamd „mata panai" ${ }^{1}$ ), die van iederen man, tegen den „Lebarandag”, één kati rijst eischte. De stand der vrijen bracht deze heffing op.

(10). Door het geheele rijk werden, òf vanwege den vorst, òf

1) „Mata panai” volgens Matthes in zijn Makassaarsch woordenboek: „oog van het opgaan" d.w.z. ,de bij uitstek geschikte dag voor het opgaan naar het paleis van den vorst".

D1. 90. 
door de hoofden "pasar"- of marktrechten van de ten verkoop geboden waren geheven. Deze werden gewoonlijk in natura opgebracht. Alleen de vrijen werden hierdoor getroffen.

(11). Eveneens werden door het geheele rijk, of vanwege den vorst of door de hoofden ,soessoeng romang”, „boschrechten”, geheven van de verkregen boschproducten. Slechts de vrijen werden getroffen.

(12). Van vischvijvers en zoutpannen werden ook rechten geheven, die onbepaald waren, evenals die onder (10) en (11).

(13). Bij de dobbelspelen werd ,tjoeké” geheven voor den vorst, zijnde een zeker percentage van den inzet; evenzoo bij de weddenschappen bij hanengevechten. Dit recht verpachtte de vorst. Hierdoor werd een ieder getroffen.

Ten aanzien van deze groep van verplichtingen van vrijen tegenover een vorst en zijn hoofden is het woord „Kasoewiyang” niet gebruikelijk.

\section{Derde groep.}

(Deze gegevens betreffen Mandar en zijn ontleend aan de nagelaten aanteekeningen van Dr. J. Mallinckrodt).

(1). Indien aan de kust hout aanspoelt, waar de wortels nog aanzitten, dan moet dat hout aan den Maradia worden afgegeven. Deze leverantie wordt ,kasoewiyang-batareppe” genoemd.

(2). Indien men voor het eerst in het seizoen „maloesoedji"-visch vangt, wordt de helft van die eerste vangst aan den vorst afgestaan, terwijl ook de leden van den rijksraad een deel ontvangen. Een eigenaardigheid hierbij is, dat men het aandeel niet aan de waardigheidsbekleeders mag ter hand stellen, maar het bij nacht aan de trappen van het huis moet ophangen, zoodat des morgens de begiftigde het gegevene daar aantreft, zonder te weten, waar het vandaan komt. Deze leverantie is ",kasoewiyang”.

(3). Als „kasoewiyang” wordt aangemerkt de betaling, die door schippers moest worden gedaan, die naar elders ten handel voeren. Deze betaling geschiedde ten behoeve van den Maradia. Naar Singapore, Borneo en Makassar uitvarende prauwen dienden resp. f 1.f 0.50 en $f 0.25$ te betalen.

Vierde groep.

(Deze gegevens betreffen Gowa vóór 1906. In de overige gedeelten van Zuid-Celebes trof men dezelfde soort van huldegiften aan). 
De Gallarrang van Soediang, één van de negen kiesheeren van Gowa, moest aan den vorst, ingevolge een oud verdrag, aanbieden de „mata panai”, het huldebewijs, dat vazallen en onderworpenen drie of vier dagen voor Lebaran en vóór „Garebeg-besar” aan den vorst van Gowa moesten brengen.

De ,mata panai” wordt in de landen om de residentie Djongaja als de oudste en voornaamste aller heffingen beschouwd, een huldebewijs, dat slechts door enkelen uit den lande den vorst mocht worden aangeboden. In de tweede groep ontmoetten wij de ,mata panai", een heffing in de bergstreken van Gowa, met name in Parigi, die merkwaardigerwijze daar een algemeene belasting was.

Voor Gallarrang Soediang nu werd als „,mata panai” vastgesteld jonge „djamboe-paratoegala"-bladeren voor het zwart maken van de tanden, en „langiri”, dat door de vrouwen gebruikt werd voor reiniging van het haar. Van elk der ingrediënten moesten twee pakken geleverd worden, gewikkeld in pisangbladeren. Wanneer deze „mata panai” aan den vorst gebracht werd, werd zij over den schouder gedragen aan een kort bamboe-juk, opdat de drager zwaar zou zwoegen en de vorst en zijn hovelingen den indruk zouden krijgen, dat het gedragene zeer zwaar was.

Bij datzelfde verdrag werd de Gallarrang van Soediang, als eenige van de kiesheeren, vrijgesteld van het voor den vorst van Gowa doen uitdragen van de lans, die overal in Zuid-Celebes als huldebewijs geldt voor den gezaghebbenden hoogeren bezoeker. Dit is „kasoewiyang”.

(2). De Gallarrangs van Tombolo en Mangasa, eveneens tot de „,batesalapang” behoorende, waren ook ,mata-panai”-plichtig. Zij hadden ",sitolong-leko" te brengen, d.w.z. sirih verpakt in den bast van den pisangboom.

(3). De „bate salapang” uit de bergstreken leverden kemiri-noten als „mata panai”. Slechts Borisallo, door een vriendschapsverdrag met Gowa verbonden, was niet „mata-panai”-plichtig.

De „mata panai” werd beschouwd als de hoogste vorm van „,kasoewiyang”. 


\section{VIERDE HOOFDSTUK.}

De standen af zonderlijk.

(Vervolg).

De hoofdengeslachten; de vrijen; de slaven.

(Vervolg).

Vijfde groep.

In den vorstentijd kende Gowa een groep van vrijen, die de „Toekadjannangang” heetten. Over de beteekenis van deze groep is nog maar weinig te vinden en omtrent den oorsprong vond ik geen enkele overlevering. De naam is niet duidelijk. „Djannang”, dat volgens Matthes, in zijn Makassaarsch Woordenboek, wellicht oorspronkelijk ,staan" beteekende is thans ,vast en bestendig zijn", „,volharden” v. d. „over iets staan of gesteld zijn”, ,het bestuur in handen hebben" en vandaar wederom de titel van een onderhoofd, een opzichter, een bewaker. Misschien kan „Toekadjannangang” met „onder djannangs staande menschen” vertaald worden.

Op de leden van deze groep rustten bepaalde verplichtingen tegenover den Vorst en de rijkssieraden van Gowa. Men vond hen zoowel in als buiten Gowa. Zij, die tot de Toekadjannangang behoorden, wisten dit zeer wel, terwijl ook ieder van de plichten, die hij als zoodanig te vervullen had, volkomen op de hoogte was. De functie van „Toekadjannangang” ging over van vader op zoon. De enkele vrouwen, die wij zoo aanstonds onder de „Toekadjannangang” zullen aantreffen, waren vermoedelijk vrouwen of dochters van „Toekadjannangang".

Zij stonden onder den „Anronggoeroe lompona Toekadjannangang', het opperhoofd der ,Toekadjannangang”, een der voornaamste rijksgrooten van Gowa, opperbevelhebber van 's vorsten leger in oorlogstijd.

Zij waren vrijgesteld van enkele verplichtingen, waaraan de andere vrijen wel hadden te voldoen. Zoo behoefden zij geen 10 duiten af te dragen aan den „Palalangiya”, degeen die te żorgen had voor het rijkszonnescherm, genaamd „Lalangsipoewéya”, als hij eenmaal 's jaars Gowa rondging volgens een oud gebruik, dat hem zijn bron van inkomsten bezorgde.

De ,Toekadjannangang” waren verdeeld in twee groepen:

1o. de eigenlijke „Toekadjannangang” onder den „Anronggoeroe Paërang", 
2o. de „Annang-Akadjannangang”.

Deze „Anronggoeroe Paërang” was belast met de regeling der zaken betreffende de rijkssieraden. De onder hem staande „Toekadjannangang" waren verdeeld in veertig groepen, elk met eigen plichten, die tezamen, met een woordspeling op het voorvoegsel „pa” bij den verzamelnaam van iedere groep, de „pa'patampoelowa”, de ,veertig pa's", werden genoemd.

Hieronder volge de opsomming:

1. „Paërang” (,erang” = brengen), die belast waren met het vervoeren en begeleiden van de tot de ,gaoekang" behoorende attributen.

2. „Paraoe” (,raoe” = rotan snijden), die de rotan moesten snijden voor het tot de rijkssieraden behoorende schild, voor de eveneens daartoe behoorende trommen enz.

3. „Pakantisi” (,kantisi” = slijpen, wetten), die de ,Soedang”, het roemruchte zwaard van Lakipadada, en andere tot de rijkssieraden behoorende wapens moesten scherpen.

4. „Padjai”, (,djai” = naaien), die belast waren met het verstellen en vernieuwen van het vorstelijke zonnescherm, van de ,tjinde”, in dit geval een niet groote, naar ik meen gebatikte zijden doek, die als baldakijn werd gebezigd voor den vorst en de rijkssieraden, en van de ,klamboe” die de ,gaoekangs” omhulde.

5. „Pabannjang” (,bannjang” = spannen), die de ,tjinde”, de .,klamboe" en andere doeken hadden te spannen en ook belast waren met het uitmeten van de plek, waarop 's vorsten woning gebouwd moest worden.

6. „Paötere” (,otere” = touwslaan), die voor de ,gaoekang” en het ,gaoekang"ritueel het benoodigde touw vervaardigden.

7. „Paöemoeng” (,oemoeng” == roosteren, doen gloeien), die elken Vrijdag en bij feestelijke gelegenheden voor de rijkssieraden wierook moesten branden.

8. „Padede" (,dede" =- smeden), die de wapens van den vorst moesten smeden.

9. „Pagoerinda” (,goerinda” = slijpsteen), die de wapens moesten slijpen.

10. „Paöedjoeng” (,oedjoeng” = anpunten), die de wapens moesten aanpunten.

11. „Patimbang” (,timbang” = wegen), die de keten „I-Tanisamanga" moesten wegen.

12. „Pabarasa” (,barasa” = vegen), die te zorgen hadden, dat de 
plaats, waar de rijkssieraden werden bewaard, werd schoongehouden.

13. „Pasere” (,sere” = dansen), die de ,pokebanranga”, de lansen versierd met paardehaar, droegen, als zij den vorst op reis vergezelden, of bij feesten.

14. „Paganrang” (,,ganrang” = langwerpige trom), de trommelslagers.

15. „Pakarena” (,karena” = spelen), de danseresjes.

16. „Padjangka” (,djangka” = kammen), de verzorgsters van de haren der danseresjes.

17. „Pasoewa” (,,soewa” =- haarwrong), die de eigenaardige haarwrong der danseresjes aanbrachten en rijkelijk van welriekende olie voorzagen.

18. „Pabembeng” (,,bembeng” = optillen, heffen), de dienaars aan de feestmaaltijden.

19. „Paroijong” (,roijong” = een soort zang), die tot taak hadden tijdens de bevalling van de vorstin onder het ceremonieel, dat daarmede gepaard ging, te zingen.

20. „Patjoewi” (,tjoewi” = eveneens een soort zang), die bij huwelijksplechtigheden speciale zangen aanhieven.

21. „Pasongko" " (,songko" " = het hoofddeksel voor de hoogere standen), die de kroon op het hoofd van den vorst moesten plaatsen.

22. „Palalangi”, de dragers van de rijkspajoeng, genaamd „Lalangsipoewéya".

23. „Pasele”, (,,sele” = kris), zij, die bij feestelijke gelegenheden diverse krissen, behoorende tot de rijkssieraden, moesten dragen.

24. „Paponto” (,ponto” = armband), zij, die belast waren met de verzorging en het dragen van de, tot de rijkssieraden behoorende armbanden.

25. „Papalili”, (,palili” = rondvoeren, tenminste in dit geval) degenen, die bij het ,apalili”, het ronddragen van de keten „,I-Tanisamanga” op het voornaamste domeinrijstveld, genaamd „Londjoboko" werkzaam waren. Hun aanvoerder was de hoofd-,,bissoe”, die den titel droeg van „Daëngta Lahaja”. Deze was de leidende persoon in alle zaken van ,gaoekang"-ritueel.

26. „Pagora” (.,gora” = schreeuwen), de jubelaars bij feestelijke gelegenheden.

27. „Panjanggaija” (,sangga” = waken voor), zij die belast waren met de visitatie van de bezoekers van het vorstelijke paleis.

28. „Pabise”, (,bise” $=$ roeispaan), de roeiers van den vorst en zijn gezelschap. 
29. „Pagantang”, (,gantang” = een inhoudsmaat), zij, die het rijstzaad voor de domeingronden van den vorst uitmaten.

30. „Pasoelengkaya” (,,soelengka” = gehurkt zitten), degenen, die aan de gasten hun zitplaatsen aanwezen bij feestelijke gelegenheden ten paleize.

31. „Pagentoeng” (,gentoeng” = hangen), die belast waren met het ophangen van de ,klamboe” van de ,gaoekang”.

32. „Paloeloe” (,loeloe” = afvegen, afdrogen), die de tot de rijkssieraden behoorende wapens moesten schoonmaken.

33. „Pakeso" (,keso” = schuren), die deze wapens moesten schuren.

34. „Parante” (.,rante” = keten), de verzorgers van de keten „ITanisamanga" en andere tot de rijkssieraden behoorende ketens.

35. „Palengoe” (,lengoe” = schild), de verzorgers van de tot de rijkssieraden behoorende schilden.

36. „Paboele”, (,,boele” = dragen), die den vorst met de vereischte attributen van zijn woning naar de kroningsplaats, en weer terug moesten dragen.

37. „Pabirang”, (,,birang” = een witte doek), die wit doek spanden boven de plaats, waar de kroning plaats had.

38. „Patjindeya”, die voor de ,tjinde”, die bij alle feesten uitgespannen moest worden, moesten zorgen.

39. „Pariwaya”, (,riwa” =-= schoot), die de ,gaoekang”-attributen en minder voorname rijkssieraden op schoot hielden gedurende plechtigheden.

40. „Patjallaka” (,tjalla” = oogenzwartsel), die het zwartsel aanbrachten bij de danseresjes.

Eenige van deze groepen hadden een eigen Anronggoeroe: men kende de Anronggoeroe's Paërang, Pabise, Pabannjang, Padede, Padjai, Paöemoeng, Pahembeng. Pakantisi, Paraoe, Paötere en Paloeloe.

De groep der „Annang-Akadjannangang” was verdeeld in, zooals de naam zegt, zes groepen, elk onder de bevelen van een Anronggoeroe. Deze zes groepen waren die van den 1. Anronggoeroe Damma, 2. Anronggoeroe Ana'gallarrang, 3. Anronggoeroe Ana'boerane, 4. Anronggoeroe Kamanakang, 5. Anronggoeroe Toelembang en 6. Anronggoeroe Tanabangka. De titel van het eerste hoofd is niet te vertalen. De overige titels luiden letterlijk vertaald: de Anronggoeroe 
van de Gallarrang-kinderen, de Anronggoeroe van de zoons, de Anronggoeroe van de neven (oomzeggers), de Anronggoeroe van de menschen uit de bergstreken en de Anronggoeroe van het gescheurde land. Wat deze namen beteekenen, is niet meer bekend. De Anronggoeroe Toelembang had inderdaad het bevel over de bewoners van de bergstreken.

Deze zes Anronggoeroe's waren verplicht om beurten zeven dagen bij het paleis van den vorst te waken. Daartoe brachten zij vier tot zes gewapende mannen mee; zelf waren zij gekleed in ,gadoe”, het Makassaarsch officieel costuum, bestaande uit een witten gazen rok en een witte ,songko'”. De plaats, waar zij waakten, was vlak vóór de deur van het paleis.

Deze verplichtingen der „Toekadjannangang” werden als „kasoewiyang" beschouwd.

\section{Zesde groep.}

Hieronder volgen een antal gegevens, waaruit opgemaakt moet worden, dat vóór 1906 in verschillende streken rijstvelden voorkwamen, die òf behoorden tot de ware domeingronden, òf tot de individueel door vorst of hoofd bezeten gronden, doch in vruchtgebruik waren gegeven aan vrijen, die daartegenover bepaalde hofdiensten hadden te verrichten. Ik zelf ben niet in de gelegenheid geweest positieve gegevens op dit punt te verzamelen ${ }^{1}$ ).

(1). ,Lang geleden,” zoo schrijft Kooreman ${ }^{2}$ ), na tevoren vermeld te hebben, dat het volgende verhaal betreffende het ontstaan van de zgn. „,kabakoekang”-velden van Gantarang in het Boeloekoembasche, hem door den regent van Gantarang is gedaan, ,werden die velden door uitgeweken Bonieren aangelegd. Nadat zij ze geruimen tijd hadden bewerkt, geraakte Bone in een oorlog, en werden die Bonieren door hun vorst opgeroepen. Zij bleven zeer lang weg, zoodat van hun velden de dijkjes bijna geheel verdwenen. Toen kwamen inwoners van Gantarang hun karaëng verzoeken die velden weder te mogen ontginnen, en daar de Bonieren al zoolang geleden heengegaan waren, en niets van zich hadden laten hooren, meende de regent, dat zij niet meer zouden terugkomen, en stond het verzoek toe.

1) In adatrechtbundel XXXI komt op blz. 125 een niet op feiten gebaseerde beschouwing over ,kasoewiyangvelden" voor, die Kooreman's theorie over kasoewiyang als uitgangspunt neemt en daarop voortfantaseert. Dit stuk kan hier dan ook niet gebruikt worden.

2) „Feitelijke toestand enz.”, Ind. Gids, 1883, II, blz. 161. 
De velden werden weder ontgonnen, en geruimen tijd geregeld bewerkt. Onverwacht kwamen de Bonieren weder, en eischten hun velden terug. Goede raad was duur; de Bonieren hadden werkelijk recht op hun velden, maar de Gantarangers hadden ze weer ontgonnen met voorkennis van hun karaëng, en hadden dus ook recht.

Een Bonisch prins vond echter een uitweg. Hij zou aan de Bonieren andere velden geven, en de Gantarangers konden de hunne behouden op voorwaarde, dat zij op zich namen de brieven van de vorsten van Boni te bezorgen. Partijen namen met die schikking genoegen, en naar gelang van de ligging der velden ${ }^{1}$ ) moesten de bewerkers brieven overbrengen naar Saleyer, Bonerate, naar Makassar en Maros, zelfs naar Ambon en Ternate.

(2). Dezelfde vermeldt ${ }^{2}$ ), dat de lansdrager van den Karaëng van Sanrabone, door dezen met het vruchtgebruik van eenige velden werd beloond.

(3). Elders ${ }^{3}$ ) zegt Kooreman dat zekere velden „kasoewiyangvelden" zijn geworden, ,dat zijn de zoodanige, waarvan de vruchtgebruiker tot bepaalde heerendiensten verplicht is."

(4). De toenmalige controleur bij het Binnenlandsch Bestuur O.M. Goedhart schreef in 1910 een uitnemend rapport over de rechten, welke door de inlandsche bevolking werden uitgeoefend op de onbebouwde gronden in de zelfbesturende landschappen, behoorende tot de afdeelingen Bone en Pare $\left.^{24}\right)$. Ik citeer daaruit het volgende: „Behalve deze „ongko's”, (de domeinjachtgronden), zijn in sommige landschappen bovendien tot eene bepaalde uitgestrektheid onbebouwde gronden speciaal ten behoeve van den betrokken Aroe gereserveerd, de zoogenaamde ,tana aradjang”, gronden, die uitstekend voor den landbouw geschikt zijn en dan ook in den regel aan de bevolking ter ontginning worden afgestaan. Ook na de ontginning blijven die gronden het eigendom van hem, die de waardigheid van Aroe bekleedt; de ontginners echter verkrijgen daarop een erfelijk individueel gebruiksrecht, dat voor vervreemding, mits geen verkoop, vatbaar is en alleen dan verloren kan gaan, wanneer aan de voorwaarden, waarop de ontginning werd toegestaan, niet voldaan wordt. Die voorwaarden zijn in den regel het presteeren van diensten ten behoeve van den Aroe en het afstaan aan dezen van een gedeelte van

1) Dit is niet duideliik.

2) Blz. 168, t.a.p.

3) Blz. 144, t.a.p.

i) Adatrechtbundel IX, blz. $189-231$. 
de opbrengst, meestal 10 (b.v. in Belawa, Wadjo) of $20 \%$ (b.v. de „tana pabiring” van Boni, Barroe, Sidenreng enz.) bedragende." Verder: „Met uitzondering van degenen, die de „ongko alě” (domeinboschgrond), ,ongko djonga" (domeinjachtgrond) of „tana aradjang” wenschen te ontginnen en welke voor die vergunning (bedoeld wordt : vergunning tot ontginning van woesten grond) $1 / 5$ of $1 / 10$ van de opbrengst van den grond moeten betalen, is voor die vergunning rechtens niets verschuldigd, doch wordt vaak door den aanvrager een klein geschenk, gewoonlijk bestaande in eenige vruchten, eieren enz. bij het aanvragen of het ontvangen der vergunning, gegeven aan het hoofd, van wien hij de vergunning heeft verzocht of verkregen."

(De zgn. ,kasoewiyang-velden" in Bone zijn de domeingronden van den vorst, welke in ,kasoewiyang” werden bewerkt, beplant en geoogst. De zgn. ,kasoewiyang-velden” in het Pangkadjenesche zijn sedert \pm 1826 Gouvernementsgronden, die in bewerking werden gegeven op voorwaarde, dat de bewerker bepaalde diensten zou presteeren voor het Gouvernement, zooals transportdiensten en grashalen voor militairen en bestuursambtenaren. Deze velden blijven dus geheel buiten bespreking.)

Z evende groep.

(1). Over de beteekenis van het woord „kasoewiyang” spraken wij nog niet. Slaan wij daartoe het Makassaarsche Woordenboek van Matthes op, dan lezen wij dat „,kassoewiyang” ${ }^{1}$ ) beteekent „hulde, gehoorzaamheid, dienst". Hij vermeldt dan nog, dat de benaming ,kasoewiyang” ook gegeven wordt aan de „,bate-salapang”, de negen kiesheeren van Gowa, ,als die meer dan anderen den koning moeten hulde brengen".

„Nikassoewiyangi" beteekent gehuldigd worden, ,kassoewiyang” ontvangen.

„Pakassoewiyang” is een „bewijzen van hulde, of gehoorzaamheid. een verrichten van arbeid voor iemand $\mathrm{v}$. d. belasting en dergelijke, als zijnde de voornaamste bestanddeelen van de ,kassoewiyang” voor een vorst".

De door Dr. Matthes in zijn Boegineesch Woordenboek vermelde Boegineesche termen gaan parallel aan de Makassaarsche. Als voorbeeld wordt bovendien nog de volgende zin opgenomen : ,banna paoe-

1) Matthes schrijft „kassoewiyang”. Ik schrijf - het Makassaarsche schrift volgende - ,kasoewiyang” evenals Niemann. 
paoe maëlo-oewakassoewiyangĕng ri Poewatta”, wat beteekent: „een verhaal is het slechts, wat ik den vorst bij wijze van „kassoewiyang” of huldeblijk wil aanbieden".

(2). Niemann zegt in een noot bij zijn artikel over de „Latowa” ${ }^{1}$ ): „Kasuwiyang”, nu en dan ook „,kasiwiyang” geschreven, beteekent hulde, gehoorzaamheid, dienst, heerendienst, verplichting tot een of ander. Dit woord, dat ook in het Makassaarsch voorkomt en misschien daaruit is overgenomen, is wel af te leiden van een grondwoord suwi of sizer, met het praefix $k a$ en suffix ang. Sizer komt nevens sizwa en sewa ook in het Kawi voor en is het Sanskritsche sewâ dat ,dienst, hulde" enz. beteekent”.

(3). De pokken worden ,kasoewiyang” genoemd. In een door Matthes in zijn Boegineesche Chrestomathie gepubliceerde pokkenzang worden de pokken, daar "sagala” genoemd, als een hooge gast toegesproken en eer bewezen.

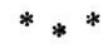

\section{Achtstegroep.}

Alvorens wij dit materiaal nauwkeuriger gaan beschouwen, zij er de aandacht op gevestigd, dat de gegevens van de eerste, tweede, derde en vijfde slechts een vrij volledig beeld geven van de op vrijen drukkende verplichtingen tegenover een vorst van een der ontwikkeldste rijken van Zuid-Celebes. Het spreekt van zelf, dat in zulk een rijk, mèt het monarchale stelsel, ook de verplichtingen zijn gegroeid. Willen wij het gevaar ontloopen, het ,kasoewiyang”-begrip door het gebruik van eenzijdig gerichte gegevens mis te verstaan, dan moeten wij ons een wijle verdiepen in het leven van de kleinste territoriale gemeenschap, in de Boegineesche landen ,wanoewa”, in de Makassaarsche landen „,banoewa” genaamd.

Als voorbeeld moge ik een der ,,wanoewa's" kiezen, waaruit het bergland Ponre, een vazalstaatje van Bone, is opgebouwd. De bevolking telt een tweehonderd zielen en woont in een twintigtal ordeloos bijeenstaande woningen in een dal. Door rijst- en maïsbouw en daarnaast door het bereiden van suiker uit het sap van de arenboom. voorziet zij in haar bestaan. Het planten van eenige andere gewassen is van geen beteekenis.

Een welomgrensd gebied staat ter beschikking van de „wanoewa”leden. In dit gebied bewerkt de gemeenschap immer zeven, niet meer

1) Adatrechtbundel XXXI, blz. 221. 
of minder, ladangcomplexen, die opeenvolgend door de gemeenschap met haar hoofd - zonder den Soellewatang van Ponre, het hoofd der hoogere gemeenschap, hier ook maar eenigszins in te kennen zijn uitgekozen, daarna door het ,wanoewa”-hoofd onder de gemeenschapsleden zijn verdeeld en opeenvolgend door de geheele ,wanoewa" gedurende twee jaren bewerkt zijn. De plaats van samenwoning blijft steeds dezelfde, doch om de twee jaren wisselen de ,wanoewa”genooten gezamenlijk van ladangcomplex. Na twaalf jaren komt de ,wanoewa" dus op het verlaten complex terug. Zulk een complex wordt grooter en grooter, en wel door de volgende oorzaken: bevolkingsaanwas, toename van werkkracht en werklust, door beter geregelde toestanden en daardoor meer verzekerd bezit, toename der behoeften en, als de voornaamste, waartegenover de andere in het niet verzinken: uitputting van den grond. Het oerwoud geeft het eerste jaar kostelijken grond, het tweede jaar reeds is de grond sterk gedegenereerd. Na twaalf jaar rust is een complex wel weer met bosch bedekt, doch het is secundair bosch met minderen grond. Zoo gaat de grond steeds achteruit en vreet de ladangbouw zich steeds dieper in het oerwoud tot in de lager gelegen streken slechts ,,alangalang" welig tiert en de ladangs tot de hoogste toppen reiken.

Het gemeenschapshoofd, zoo werd tevoren reeds gezegd, verdeelt een complex ladangs bij den inzet van iedere tweejarige periode opnieuw onder de leden der gemeenschap. Hij treft deze verdeeling zoo goed mogelijk, rekening houdend met een ieders behoeften.

De verdeeling wordt getroffen vóór het kappen der boomen; daarna worden de verschillende deelen door alle werkbare mannen der gemeenschap achtereenvolgens gekapt, waarbij de aanstaande bewerker van dat deel, dat gekapt wordt, voor eten zorgt. Alvorens een ieder zich aan zijn eigen deel wijdt, bewerken de leden der gemeenschap de ladang van het ,wanoewa"-hoofd, die soms tweemaal, soms viermaal de ladang van den gemiddelden gewonen man beslaat.

Als, na twaalf jaren, de ,wanoewa" terugkeert op een complex, behoeft het hoofd geenszins de eerste verdeeling te handhaven, en dit gebeurt dan ook vrijwel nooit.

$\mathrm{Na}$ den laatsten oogst valt het geheele complex onmiddellijk weer terug aan de gemeenschap.

Zooals vanzelf spreekt is noch van vervreemding, noch van eenig individueel recht sprake.

De inwoner eener ,wanoewa”, die in den vorstentijd ladangs opende zonder vergunning van zijn hoofd en zich aldus aan het gemeen- 
schapsverband onttrok, werd - naar men mij in sommige ,wanoewa's" zeide - beboet met twee rijksdaalders en drie kwartjes.

Bij niet-betaling binnen zekeren termijn werd de overtreder uitgezet, terwijl de hem toebehoorende roerende goederen aan het „wanoewa"-hoofd vervielen. In enkele ,wanoewa's" kende men geen boete, doch slechts uitbanning van den overtreder.

Vreemdelingen kunnen nimmer gronden ter bewerking verkrijgen, tenzij zij behooren tot een gemeenschap, waarmede de eigen ,wanoewa", in het bijzonder op dat punt, een plechtige overeenkomst heeft aangegaan.

Zulk een overeenkomst hebben in oude tijden de Aroe's van de „,wanoewa's" Ponre, Tjiro en Bakoeng aangegaan, als gevolg waarvan de ladang-complexen dier gemeenschappen in elkanders gebied grijpen.

Wij vinden hier in dit ladanggebied dus geen door vrijen bewerkte, beplante en geoogste vaste domeingronden, doch in de plaats daarvan ontginning, bewerking, uitzaaien of poten der gewassen, door de gemeenschapsleden ten behoeve van het hoofd, van en op een stuk grond, dat eenige malen grooter is dan dat van den gewonen man. Het ,wanoewa"-hoofd leidt alle werkzaamheden en behoeft bij den arbeid zelf niet mede te doen. Wat de gemeenschapsleden voor hun hoofd doen, is gedeeltelijk hetzelfde, als wat zij voor elkander doen, alleen is van het hoofd geen reciprociteit te verwachten. Het ten behoeve van het hoofd verrichte werk is ,kasoewiyang”. Zoo is het ook met den bouw van een woning. Wil een der gemeenschapsleden een huis bouwen, zoo helpen de anderen hem daarbij. $Z$ ij weten dat zij. indien zij deze behoeven, op een contraprestatie in denzelfden vorm kunnen rekenen. Voor het hoofd evenwel wordt een huis gebouwd, zonder dat van eenige contraprestatie sprake is, ongerekend het verschaffen van eten aan de werkers tijdens den bouw. Doch deze verplichting rust ook op de gewone lieden, als zij bij den bouw van een huis hulp van hun gemeenschapsgenooten ontvangen. Voor het hoofd verrichten de gemeenschapsleden, ook waar het huizenbouw betreft, ,kasoewiyang”.

In zulk een kleine, eenvoudige gemeenschap ontbreken nog de geregelde heffingen in natura of geld, zooals wij die in Gowa ontmoetten. De behoeften van het hoofd en de zijnen gaan vrijwel niet uit boven die van den gewonen man. Hij heeft meestal een grooter huis, zeker, en hij heeft meer rijst en mais, maar overigens onderscheidt hij zich in zijn levenswijze niet van zijn onderhoorigen. Als 
hij voor huishoudelijk gebruik eenige stukken palmsuiker noodig heeft, kan hij deze vragen. Hij krijgt de suiker dan ten geschenke.

Als ,kasoewiyang” aan den vorst van Bone, gaf iedere „,wanoewa” jaarlijks de zoogenaamde ,apopang” rijst en de ,apopang” peulvruchten, die door den geheelen Archipel bekend zijn als „katjang idjoe”. (Een ,apopang” is een mand, gemaakt van de bloemtrosscheede van de pinang en ook een inhoudsmaat, gelijkstaande met drie „tjoepa's” of klapperdoppen). Voorts stond iedere suikertapper jaarlijks, als „kasoewiyang”, één stuk suiker af voor den vorst, welke suiker dan tegelijk met de ,apopang" van iedere „wanoewa”, door het hoofd van den vazalstaat Ponre aan den vorst werd aangeboden.

In sommige ,wanoewa's" trof ik het gebruik aan, om bij huwelijken de ,,aradjang” een geschenk te geven in den vorm van een ,klamboe”, een bord, een koperen blad om offergaven op te leggen, of iets dergelijks. Dit is „kasoewiyang”.

Van de door vrijen aan vorsten, rijksgrooten en hoofden bewezen diensten en ook van de verplichtingen van hoofden tegenover vorsten genoemd in de eerste, derde, vierde, vijfde, zesde en achtste groep staat vast, dat deze als ,kasoewiyang” moeten worden beschouwd. Ten aanzien van de tweede groep gegevens is de term ,kasoewiyang” niet gebruikelijk, doch, waar elders soortgelijke verplichtingen, te weten verplichte giften in natura en geld, wel onder ,kasoewiyang” vallen (III. 1, 2, 3; IV. 1, 2, 3; VIII) ${ }^{1}$ ), en Matthes bovendien (VII) uitdrukkelijk van ,,belasting als een vorm van ,kasoewiyang” " spreekt, is het, dunkt mij, gerechtvaardigd, ook de verplichtingen genoemd in deze groep van gegevens, te beschouwen als „kasoewiyang”. Slechts ten aanzien van de „tjoeké”, geheven van de inzetgelden bij dobbelpartijen en hanegevechten blijft voor mij onzekerheid bestaan.

Omdat Kooreman uitdrukkelijk verklaart, dat men in de vorstenlanden onder ,kasoewiyang” al datgene verstond, waartoe men volgens de adat verplicht was, en al wat de vorst geliefde te bepalen of eischen, ben ik genoodzaakt een greep te doen uit de overstelpende hoeveelheid adatverplichtingen, die geen ,kasoewiyang” zijn. Geen „kasoewiyang” is - om eerst bij het zooeven gegeven materiaal te blijven - de verplichting voor vorst, rijksgroote of hoofd om eten te

1) Het romeinsche cijfer duidt de groep van gegevens aan, het andere betreft de onderverdeeling der groep. 
verschaffen of bossen rijst af te staan aan de werkers op de domeingronden (I. 1), om eten te verschaffen bij woning- of ",baroega"bouw (I. 2, 3.) of bij den bouw van een moskee of ,langgara” (I. 4.) : evenmin het verschaffen van voedsel gedurende reizen (I. 6), het afstaan van een deel van den buit bij jacht- of vischvangst (I. 7.), het verschaffen van eten bij wachtdiensten, waterhalen en brandhout halen en kappen (I. 8). Ook niet het verschaffen van eten door het ,wanoewa"-hoofd of door een der gemeenschapsleden aan de werkers op de ladang van hoofd of ,wanoewa"-genoot. Geen ,kasoewiyang” is het verdeelen van het ladangcomplex, waartoe de adat het ,wanoewa”hoofd verplicht (VIII). Geen ,kasoewiyang" is de verplichting van den ,wanoewa"-man, om het geheele ladangcomplex te helpen ontginnen en bewerken (VIII). Geen ,kasoewiyang” is het betalen van de huwelijksgift, hoewel dit toch een verplichting is zoo men wil huwen, of het dragen van de ,gadoe", het officieele gewaad, bepaaldelijk aan het Gowasche hof, als de adat dit eischt. Ook niet het eten van bepaalden kost vóó het uitzaaien van de rijst, of het plegen van allerlei magische handelingen door den schipper, alvorens de handelsprauw wordt geladen en gereed gemaakt voor het vertrek.

Ik zou zoo door kunnen gaan, doch nu reeds zal het duidelijk zijn, dat ,kasoewiyang" iets anders is dan ,,al wat door de adat verplichtend is gesteld."

Bezien wij ons eigen materiaal dan dringt zich onmiddellijk deze gevolgtrekking aan ons op, dat al wat ,kasoewiyang” wordt genoemd, in de eerste plaats een dienst is.

In de tweede plaats zijn deze diensten verplicht. Daar dit uit de hiervoor gerangschikte gegevens niet duidelijk is op te maken, moge dit punt hier nader worden behandeld. Of een dienst al dan niet verplicht is, kunnen wij eerst vaststellen, indien wij op de hoogte zijn van de normale gevolgen, die een wanprestatie heeft. De vraag, die ons thans zal bezig houden is dus, welke gevolgen voor den „,kasoewiyang"-plichtige verbonden zijn aan nalatigheid in het vervullen van zijn „,kasoewiyang”-plicht. Kooreman zegt, zooals wij zagen, dat, indien aan de ,kasoewiyang"-plicht niet wordt voldaan, aan den „kasoewiyang"-plichtige de grond kan worden ontnomen, waarvan hij het erfelijk vruchtgebruik heeft. Dat het voorgekomen zal zijn, dat op den grond van een nalatigen ,kasoewiyang”-plichtige beslag is gelegd, neem ik onmiddellijk aan. Kooreman wekt evenwel den verkeerden indruk, alsof dit de eenige aan ,kasoewiyang”-nalatigheid verbonden sanctie zou zijn. Niets is minder waar. In den Gowaschen 
vorstentijd werd iemand, die zonder geldige reden nalatig was in het vervullen van ,kasoewiyang” in den zin van de eerste groep, daartoe gedwongen. Hij werd gehaald, desnoods met geweld. Dit laatste zal evenwel - de verhouding van hoog en laag, die wij in het volgende hoofdstuk beter zullen leeren kennen, in aanmerking genomen zelden zijn voorgekomen. De nalatige kon dan tot een boete van twee of drie realen (vier of zes gulden) veroordeeld worden. Bleef iemand in gebreke een heffing, als bedoeld in de tweede groep, op te brengen, dan werd ò op een deel der zich in zijn handen, huis of opslagplaatsen bevindende voortbrengselen of goederen beslag gelegd (II. 1, 2, $3,6,7,8,9,10,11,12$ ) òf werd beslag gelegd op den inhoud of een gedeelte van den inhoud van de prauw of op de prauw zelf (II. 4, 5). Soms werd dan nog een boete opgelegd. Men moet zich echter niet voorstellen, dat de inning van en de contrôle op deze heffingen goed geregeld was. Van de hoofden, de onderhoofden en de lage beambten hing het af of er streng werd opgetreden of niet. De een liep vrij, de ander niet. Willekeur vierde hoogtij. Zoo zal het ongetwijfeld ook zijn voorgekomen, dat lieden, die hun ,kasoewiyang”-plicht hadden verzaakt, van hun gronden werden verjaagd. Dat deze verjaging in de adat wortelt, is echter voor mij onaannemelijk. Zij draagt geheel het karakter van machtsmisbruik. Iets anders is het, wanneer de „,kasoewiyang"'-plichtige, ontevreden over ondervonden behandelingen van de zijde van zijn hoofden, - en als voorbeeld kunnen wij dan zeer wel een inbeslagname van goederen wegens werkelijke of vermeende ,kasoewiyang"-nalatigheid nemen - de gemeenschap verlaat $\left.{ }^{1}\right)$. Hij verliest daarmede zijn rechten op de tevoren door hem bezeten gronden. Het verlies dezer rechten is hier secundair, het verhuizen primair. Zeker is dit verlies van rechten geen noodwendig gevolg van het verzaken van den ,kasoewiyang”-plicht.

Hoewel hieromtrent geen zekerheid is te verkrijgen, acht ik het niet waarschijnlijk, dat nalatigheid in het verrichten van ,kasoewiyang" in den zin van de eerste twee groepen anders dan hoogstzelden voorkwam. Nalatigheid ten opzichte van de „kasoewiyang” van de vierde groep was vrijwel ondenkbaar. Wat er gebeurd zou zijn, indien een der leden van de ,bate salapang” de „mata panai” eens niet had gestuurd, kunnen wij slechts gissen. In Bone werd een wederspannige vazal eerst gesommeerd zijn verplichtingen na te komen, vervolgens werd hij eenmaal of meermalen na-

1) Het verhuizen naar een andere streek uit ontevredenheid met hoofd of hoofden is een door geheel Indonesië bekend verschijnsel. 
mens den vorst van Bone bezocht door een der leden van den raad van zeven, en zoo dit nog niet het gewenschte resultaat had, werd de "Pengoeloe-djowa”, de bevelhebber van 's vorsten lijfwacht, aan het hoofd van de lijfknechten naar het onverzettelijk hoofd gezonden. Dit mocht dan niet meer inbinden, maar mòest dan een gevecht aangaan, waarin het meestal den dood vond. Bracht het hoofd het er levend af, dan werd het gevangen genomen en vervallen verklaard van zijn waardigheid, meestal met zijn nazaten tot in het zooveelste geslacht.

Nalatigheid ten aanzien van de ,kasoewiyang” van de vijfde groep behoort eveneens tot de onwaarschijnlijkheden. De diensten der „Toekadjannangang”, die tezamen de „Pa'patampoelo” werden genaamd, waren zeer licht en bovendien van een aard, die het vervullen daarvan begeerlijk en het zich onttrekken daaraan hachelijk maakte. De diensten van de „Annang-Akadjannangang” waren niet zoo licht, doch zeer eervol. Omtrent het straffen van nalatige „Toekadjannangang" staan mij geen gegevens ten dienste.

De ,kasoewiyang”, die in de zesde groep wordt behandeld (VI. 1, 2,3 ) is inhaerent aan het vruchtgebruik van een zeker stuk grond, dat tot de domeingronden of de particuliere velden van een vorst of hoofd behoort. Het behoorlijk verrichten van bepaalde diensten is voor den vruchtgebruiker de eerste voorwaarde voor het behoud van zijn recht van vruchtgebruik. Is hij nalatig, dan vervalt tegelijkertijd de reden, waarom hem het stuk grond in vruchtgebruik is afgestaan.

Zagen wij, dat ,kasoewiyang” in de eerste plaats een dienst is en in de tweede plaats een verplichte dienst, in de derde plaats kunnen wij aan de hand van ons materiaal vaststellen, dat het een verplichte dienst is, die door een lagere aan een hoogere wordt bewezen. De gegevens van de zevende groep wijzen ook geheel in deze richting. Opmerkelijk is in dit verband, dat Kooreman's enkele reeds geciteerde voorbeelden van ,kasoewiyang” - een of twee, die zoo aanstonds besproken zullen worden, uitgezonderd - aan dit criterium voldoen. Verplichtingen van hoog tegenover laag en gelijk tegenover gelijk zijn geen „,kasoewiyang”. Voorzoover mij bekend is, werd dit tot dusver nog nimmer duidelijk in het licht gesteld. Het is dan ook geen wonder, dat Prof. van Vollenhoven in zijn „Het adatrecht van Nederlandsch-Indië', voornamelijk aan de hand van Kooreman's genoemd artikel, schreef: „Voor rechtsverplichtingen, van wien tegenover wien ook is de algemeene term ,.kasoewiyang” ${ }^{1}$ ).

1) I., blz. 372 .

D1. 90. 
Gaan wij vervolgens na, wie ,kasoewiyang"-plichtig zijn tegenovo wie, dan vallen onze gegevens in twee groepen uiteen: de „kasoewiyang" van de vrijen aan de met regeermacht bekleeden als vorsten, rijksgrooten en hoofden, en de „kasoewiyang” van hoofden aan hoogere hoofden en vorsten. Deze nu, vertoonen in hun aard aanmerkelijke verschillen. De „kasoewiyang” der vrijen toch is gedeeltelijk economisch (voedselvoorziening: I. 1, 5; II. 1, 3, 4, 6, 7, 8, 9, 11, 12; VIII ${ }^{1}$ ); huizenbouw: I. 2; VIII; geldelijke verplichtingen: II. 2, 4, 5; III. 3; andere economische verplichtingen: I. 6, 8), gedeeltelijk religieus (I. 3, 4, 7 ; III. 2; V. 1; VIII) en gedeeltelijk sociaal (I. 9) ${ }^{2}$ ). De ,kasoewiyang” van de hoofden tegenover de hoogere hoofden en de vorsten is niet van economische beteekenis.

De kiesheeren van Gowa hadden twee vormen van ,kasoewiyang" te verrichten, namelijk het dragen van de lans en de "mata panai." De ,mata panai” is mijns inziens een geschenk van magischen aard, dat echter, ongeacht het geschonkene, in de eerste plaats teeken is van onderworpenheid van den schenker aan den ontvanger. Het geschenk, de ,kasoewiyang”, heeft hier een politieke beteekenis en als zoodanig alleen werd het nog begrepen.

Over het verband tusschen „kasoewiyang” en de rechten op grond zweeg ik tot dusver. Had Kooreman dit verband niet gelegd, ik zweeg nog. Waarschijnlijk baseert Kooreman zijn meening, dat de verplichtingen van kleine luiden, hoofden, ,anakaraëngs" en ,karaëngs”, die onder den naam ,kasoewiyang" worden begrepen, onverbrekelijk zijn verbonden aan de door deze personen bezeten gronden 1o. op het voorkomen van gronden, aan het vruchtgebruik waarvan bepaalde verplichtingen zijn verbonden (VI) en 2o. op het vermeende feit, dat het recht van vruchtgebruik op grond alleen verloren gaat ingeval de vruchtgebruiker niet naar behooren aan zijn "kasoewiyang” voldoet.

$\mathrm{Nu}$ zijn de gronden uit de zesde groep uitzondering. Kooreman doet het voorkomen of aan het vruchtgebruik van allen grond bepaalde verplichtingen verbonden zijn. Als dit zoo was, zou het voorkomen van velden, die, als uitzondering, ,kasoewiyang”-velden heeten, juist omdat aan het vruchtgebruik van speciaal deze gronden bepaalde verplichtingen verbonden zijn, ten eenemale onbegrijpelijk

1) Daar groep VIII geen onderverdeeling heeft, moet nadere aanduiding achterwege blijven.

2) De grenzen zijn niet altijd scherp te trekken. 
zijn. Doch niet alleen grondbezitters waren „,kasoewiyang"-plichtig, al vormen deze, in een landbouwland als Zuid-Celebes, de overgroote meerderheid. Het staat vast, dat knapen, zeker geen grondbezitters, „kasoewiyang" verrichtten in den vorm van lichte hofdiensten bij vorsten en hoofden. Doch ook jonge mannen, ,kasoewiyang”-plichtig, bezaten dikwijls geen grond. Ook kleine visschers en kleine handelaars, die vaak geen grond bezaten, waren toch ,kasoewiyang”plichtig. De deelbouwers, die tegen een zeker gedeelte van den oogst, door anderen bezeten gronden in vruchtgebruik hadden, waren ,,kasoewiyang”-plichtig en slechts het niet opbrengen van de „tesang” kon over het algemeen den deelbouwer zijn grond doen verliezen; wan-prestatie ten aanzien van „,kasoewiyang” in ieder geval niet. Welke grondrechten zouden aan de „kasoewiyang” van Galarang Soediang verbonden kunnen zijn? En welke aan de „,kasoewiyang” van een buiten Gowa wonenden „Toekadjannangang”?

Bepaald onjuist moet Kooreman's uitspraak worden geacht, dat het recht van vruchtgebruik alleen verloren ging ingeval iemand niet naar behooren aan zijn ,kasoewiyang' voldeed. Jemand, die wegens misdaad tot slavernij was gebracht, verloor zijn grond en bovendien al zijn ander goed. Verbeurdverklaring van goederen - zonder dat de man tot slavernij werd veroordeeld - was ook als straf bekend; hij werd daarbij van de door hem bezeten gronden verjaagd. Indien iemand zijn dorp metterwoon verliet zonder orde op zijn zaken te stellen, vervielen zijn rechten op de door hem bezeten gronden. Zooals ik reeds zeide, acht ik het zeer wel mogelijk, dat het verzaken van ,kasoewiyang”-plichten, ook voor andere groepen dan de zesde, verjaging van den grond tengevolge kon hebben, doch ik acht deze ontzetting uit grondrechten uitvloeisel van machtsmisbruik.

Kooreman schijnt het verband tusschen de rechten op grond en het verrichten van ,kasoewiyang” als een axioma te hebben aangenomen. Hoe dit hem parten heeft gespeeld, blijkt daar, waar hij zegt dat onder ,kasoewiyang" vroeger ook werd begrepen de verplichting om te wonen in het district, waar de grond was gelegen, waarvan men het erfelijk vruchtgebruik genoot. „Dit verklaart”, zegt hij ,het algemeen geldend gebruik om de gronden verbeurd te verklaren van misdadigers, die zich door de vlucht aan straf onttrekken". Kooreman's redeneering was vermoedelijk deze: ,kasoewiyang"-plicht en het recht van vruchtgebruik op grond zijn onverbrekelijk met elkander verbonden; alleen dus wanneer de ,kasoewiyang"-plicht wordt verzaakt, vervallen de rechten op den grond; verlaat iemand een 
district - wat Kooreman hieronder verstaat doet niet ter zake -dan verliest hij de rechten op den tot dusver door hem bezeten grond in dat district; daarom moet het wonen in hetzelfde district als waarin de grond is gelegen ,kasoewiyang” zijn; in Kooreman's tijd evenwel was er niemand te vinden, die dat wonen „kasoewiyang” noemde, waaruit Kooreman de conclusie trok, dat het dan vroeger zoo geweest moest zijn. „Tegenwoordig”, laat Kooreman er op volgen, ,moet de vruchtgebruiker of zelf in het district wonen, of ten genoegen van het betrokken districtshoofd een in het district woonachtigen vervanger stellen, die op zich neemt de aan den grond verbonden ,kasoewiyang” te presteeren. Wordt daaraan niet voldaan, dan komt de grond weder ter beschikking van het district". Hiertegenover kan ik slechts dit aanvoeren, dat ik zelf de verplichting tot het aanwijzen van een vervanger nergens heb aangetroffen. In de bergstreken van Bone, als Ponre, Kahoe en Tjani is recht op grond in een bepaalde ,wanoewa” slechts te verwerven voor hen, die zich metterwoon in deze „wanoewa” hebben gevestigd. In de lage landen, waar het erfelijk individueel bezitsrecht op sawahs overheerscht, is dit niet het geval. Daar verrichtte de vrije zijn „kasoewiyang” in den zin van de eerste groep, in de gemeenschap waar hij woonde. De plicht tot het verrichten van „kasoewiyang” in den zin van de tweede groep werd vervuld daar, waar de producten, waarvan een gedeelte moest worden opgebracht, geoogst of gezameld waren (II 1, 3, 6, $7,8,9,11,12)$, waar de handelsprauwen binnenvielen, uitvoeren of ankerden (II 4, 5), waar de waren werden verhandeld (II 10) of waar men woonde (II, 2).

Zoozeer was Kooreman overtuigd van het bestaan van een onverbrekelijken band tusschen recht op grond en „kasoewiyang”, dat hij het voldoen van schulden ook al tot "kasoewiyang” wilde rekenen, omdat.... iemand, die het vruchtgebruik van gronden heeft en nalatig is in het voldoen van zijn schulden, gedwongen kan worden om ò zijn recht te verpanden en met de pandsom zijn schulden te voldoen, òf zijn recht in pand af te staan aan zijn schuldeischer!

De gevolgtrekkingen, die wij naar aanleiding van Kooreman's mededeelingen maakten, behoeven na het bovenstaande, naar mii dunkt, herziening ${ }^{1}$ ).

(1). Het woord "kasoewiyang” ware het best te vertalen, niet met „verplichtingen” doch door ,;bepaalde verplichte huldediensten in

1) B1z. 523 . 
arbeid, voortbrengselen of geld". (2). Inderdaad waren niet alleen de kleine luiden doch ook de hoofden ,kasoewiyang"-plichtig. (3). Het bestaan van een band tusschen ,kasoewiyang” en grondbezit was uitzondering en betrof slechts het grondbezit van bepaalde vrijen. (4). Dat de ,kasoewiyang" verschillend was naar den stand is onjuist. Wij kunnen niet spreken van de ,kasoewiyang” van de „,ana'-tino" - - om in Gowa te blijven -- of van de ,ana'-sipoewé”. Wij kennen ,kasoewiyang" van hoofden tegenover hoogere hoofden en vorsten, die anders is dan de ,kasoewiyang" van vrijen tegenover met regeermacht bekleeden, terwijl de slaven niet ,kasoewivang”plichtig zijn. (5). Dat men in de vorstenlanden ten tijde van Kooreman onder ,kasoewiyang” al datgene verstond, waartoe men volgens de adat verplicht was, moet onjuist zijn. (6). Het recht van vruchtgebruik ging niet alleen verloren ingeval de vruchtgebruiker niet naar behooren aan zijn ,,kasoewiyang” voldeed.

Samenvattende kunnen wij het begrip ,kasoewiyang” thans aldus omschrijven: "Kasoerriyang” is een stelsel van verplichte diensten, die eensdecls en vooral van economischen, religieuzen en socialen aard zijn en door den stand der vrijen in arbeid, voortbrengselen of geld worden gepresteerd ten behoeve van de boven hem gestelde regeerders, en anderdeels ineer van politieken aard zijn en door hoofden in natura en arbeid rorden gepresteerd ten bchoeve van hoogere hoofden en vorsten.

In deze definitie is voor het leggen van een band tusschen rechten op grond en ,kasoewiyang” geen plaats. De meening van Prof. van Vollenhoven, dat het voldoen van ,kasoewiyang” een element zou zijn van het inlandsch bezitsrecht op grond ${ }^{1}$ ), kan ik dan ook niet deelen.

\section{VIII.}

De slaven.

Men kende bij de Makassaren en Boegineezen drie bronnen van slavernij: den oorlog, den menschenroof en de rechtspraak. De vele oorlogen brachten geregeld vele strijders van weerszijden in krijgsgevangenschap. Deze krijgsgevangenen vervielen meestal tot slavernij. $Z$ ij werden òf donr den vorst, òf door den voornamen edelman, die hen met zijn menschen had gevangen genomen tot erfslaaf gemaakt, òf verkocht. Het schijnt, dat krijgsgevangenen altijd erfslaaf werden.

1) „Het adatrecht van Ned.-Indië”, I, blz. 378 . 
De menschenroof werd op tweeërlei wijze uitgeoefend: ter zee en te land. Ter zee door zeeroovers, die de bemanning der buitgemaakte vaartuigen gevangen nam en daarna aan den wal verkocht; te land vaak onder de auspiciën van vorstentelgen of andere voorname edelen, die dan onder een of ander voorwendsel een inval deden of lieten doen in de Toradjalanden. Honderden mannen, vrouwen en kinderen werden dan gevangen genomen, weggevoerd en als slaaf door de roofridders behouden of verkocht. Ook dit zouden altijd erfslaven zijn geweest. Kwam oorlog en menschenroof in de laatste eeuw niet zooveel meer voor, men kan er van overtuigd zijn, dat de rechtspraak tot in het hegin van deze eeuw in de gebieden, die toen nog niet onder Westersch bewind stonden, een geregeld vloeiende bron is gebleven. Op misdrijven tegen de veiligheid van den staat en den vorst stond, zoo niet de doodstraf werd uitgesproken, erfslavernii, tenminste voor de vrijen. Voor het misdrijf van schaking was veelal slavernij de straf. Doch nog op een andere wijze kon een rechterlijk vonnis de oorzaak worden van slavernij. Indien iemand wegens misdrijf veroordeeld werd tot het betalen van een boete en hij kon deze boete, hoe hij ook had getracht aan geld te komen, niet betalen, dan bleef hem nog één middel: zich zelf als slaaf te verkoopen. De koopsom diende dan tot kwijting van de boete. Op dezelfde wijze eindigde een schuldenaar, die als hooge uitzondering nergens hulp vond en zelfs geen pandeling kon worden, ten aanzien van wien de rechter besliste, dat hij toch de schuld had te voldoen. Hij verkocht zichzelf als slaaf.

In de „Latowa” worden zij slaaf genoemd: (1) die als koopwaar rondgevoerd worden en verkocht worden, (2) die zeggen : ,koop mij”, en gekocht worden, (3) die in den oorlog hun vrijheid hebben verloren en gekocht worden, (4) die een misdrijf tegen vorst en rijksraad hebben bedreven en daarom verkocht zijn.

Wanneer de rijksraad iemand tot betaling van een boete veroordeelt, zoo gaat de „Latowa” dan vrijwel letterlijk verder, en de veroordeelde zoekt geld en vindt iemand, die hem dat geeft, dan is hij geen slaaf, doch een ,toriwaramparangi”, d.w.z. „,een met goederen geholpene". Vindt hij echter geen hulp, dan kan de rijksraad zeggen: ,ga je zelf tôt „sanra poetta" ${ }^{1}$ ) maken. Gelukt ook dit niet, dan zegt de rijksraad: ;, Ga je zelf verkoopen; zoo ge dan nog geen geld

1) Dit is een op volle waarde getaxeerd pand, persoon of goed, waarvan de inlossing afhankelijk is van den wil van den pandnemer. De mogelijkheid van inlossing is het eenige onderscheid met koop. 
krijgt, zal de rijksraad zelf je verkoopen". Is er dan iemand, die geld geeft, dan overlegt de veroordeelde met dengeen, die geld heeft gegeven; zegt deze: ,ik heb je geen geld gegeven, maar ik heb je gekocht", dan heeft de veroordeelde zich daar bij neer te leggen en is hij een slaaf.

Heeft iemand veel schuld - schuld van zijn ouders of die hij zelf gemaakt heeft - welke zijn familie niet wil betalen, terwijl zijn schuldeischer hem niet als pandeling wil aanvaarden en ook anderen hem geen geld willen geven. en zulk een persoon verschijnt voor den rechter zeggende, dat hij niet tot pandeling genomen kan worden, dan behoort, indien noch de rechter, noch de rijksraad hem wil helpen, deze schuldenaar door zijn schuldeischer te worden verkocht. Zoo iemand hem koopt, is hij een slaaf.

Tot zoover de „Latowa” op dit punt. Zooals wij zagen vond van Rhijn in Wadjo, dat men voor gewone schulden slechts pandeling kon zijn. Alleen bij leening als gevolg van misdrijf kon men slaaf worden. Wij kunnen wel aannemen, dat het overal de gewone gang van zaken was, dat men vanwege wanbetaling van gewone schulden hoogstens pandeling en vrijwel nimmer slaaf werd.

In dit verband zij vermeld, dat Bakkers schrijft ${ }^{1}$ ), dat de pandelingen veeleer vermeerderen dan dat zij verminderen, waartoe de wijze van rechtspraak der Bonieren niet weinig bijdraagt. Deze pandelingen zijn voor het meerendeel hartstochtelijke dobbelaars of ,amfioenschuivers”, die cloor de vele schulden, die zij maken, niet meer in staat zijn, die terug te betalen en zich zoodoende voor goed verpanden ${ }^{2}$ ).

„In de eerste jaren hunner pandelingschap”, aldus Bakkers in 1866, ,worden zij nog als zoodanig door hunne schuldeischers beschouwd, doch zijn zij na eenigen tijcl niet in staat zich wit te lossen, dan worden zij door den pandhouder als slaven beschouwd, welke slavernij dan van de ouders op de kinderen overgaat".

Tot slavernij vervielen meestal lieden uit den stand der vrijen. Onmogelijk was het niet, dat iemand uit den adelstand tot slavernij werd veroordeeld, tenminste als men den geest, waarin de schrijvers in de „Latowa” over de hoogheid van de rechtspraak spreken, in aanmerking neemt; doch hier zal de natuur wel sterker geweest zijn dan de leer. Een siaatsgevaarlijk Boegineesch of Makassaarsch edel-

1) J. A. Bakkers, „Het leenvorstendom Boni”, Tijdschrift voor T. L. en V., XV, blz. 153.

2) Deze uitdrukking is natuurliik niet juist. 
man zal nog eerder door moordenaarshand vallen, dan door zijn eigen groep tot slaaf worden gemaakt. Onder hen, die tot slavernij vervielen, doordat zij in krijgsgevangenschap geraakten, kwamen wel edellieden voor, doch meestal werden de voornaamste gevangenen bij het sluiten van den vrede wederkeerig uitgeleverd.

\section{IX.}

Een slaaf was in het algemeen in het geheele Boegineesche en Makassaarsche gebied een geminacht wezen. Vooral de niet-Boegineezen en -Makassaren onder de slaven, de van roof- en krijgstochten medegebrachte Toradja's, Boetonneezen, of wat het voor lieden, soms afkomstig uit de Molukken, waren, werden nauwelijks als menschen beschouwd. Eigenlijk is de man van slavenafkomst nog steeds een door de hoogere standen geminacht persoon. Het is mij vaak genoeg overkomen, dat mijn chauffeur, mijn oppasser of mịn paardenjongen, dus zelf zeer eenvoudige lieden, mij met innige verachting mededeelden, dat de sollicitant voor dit of dat baantje eigenlijk een slaaf was. In het volgend hoofdstuk, waar ik o.m. de onderlinge verhouding der standen op het gebied van het huwelijk bespreek, blijkt ook clat tot op den huidigen dag de vrije er voor terugschrikt zijn dochter te geven aan een man met slavenbloed in de aderen.

Deze minachting blijkt ook - zooals begrijpelijk is - uit allerlei uitdrukkingen. Ik noemde reeds den naam „Ata-taï-djangang”, de „,kippendrek-slaven”, waarmede in Gowa de erfslaven werden bedoeld. Merkwaardig is de naam „Djawa-djawa”, dat eigenlijk Java. Javanen beteekend en dat gebruikt wordt of werd, volgens Matthes in diens beide woordenboeken, voor de ,menschen van Boeton, Soembawa en andere overwalsche rijken, die gewoonlijk tot de ergste slavernij gedoemd zijn”. „Agaoe-djawa-djawa” (Mak.) en „Magaoedjawa-djawa” (Boeg.) beteekenen ,zich als een slaaf gedragen”, vandaar ,ongemanierd zijn”, vandaar ,,slechte dingen doen”. ,Atinrodjawa-djawa” (Mak.) en „Matinro-djawa-djawa” (Boeg.) beteekenen ,als een slaaf slapen”, zonder behoorlijke legerstede. „Nganredjawa-djawa” (Mak.) en "Manre-djawa-djawa (Boeg.) is ,als een slaaf eten” vandlaar ",slecht eten krijgen”, ,,ongemanierd eten”. Zoo ook „Akana-djawa-djawa” (Mak.) en „Mapaoe-djawa-djawa”, ,als een slaaf spreken” en „Agiyo-djawa-djawa” (Mak.) en „Kedodjawa-djawa” (Boeg.), .,zich als een slaaf bewegen”. 
Duister, althans voor mij, is de oorsprong van de uitdrukking „Ana'-boelaëng” (Mak.) en „Ana'-oelawang” (Boeg.), dat ,,slavenkinderen" beteekent, terwijl de letterlijke vertaling ,goudkinderen" is.

Hoe geminacht de slaven in het algemeen ook zijn, toch waren er uitzonderingen. De slaven aan het hof verkeerden in een bijzondere positie. Deze positie was zelfs zoo bijzonder, dat een der schrijvers in de „Latowa” zich genoopt voelde ernstige vermaningen te richten tot deze slaven, om toch vooral welwillend en niet te hooghartig tegenover de gewone vrijen te zijn. Men kan zelfs - zooals ook Niemann trouwens vermeldt ${ }^{1}$ ) - het volgende lezen: „Indien de ,ataribolang” (de hofslaven) en de „pabanoewa” (de kleine luiden) tezamen eenig werk verrichten en gelijkelijk misdoen, worden de eersten toch steeds als onschuldig beschouwd...., anders zouden de hofslaven niet meer ontzien worden dan de „pabanoewa”, want daarom slechts zijn deze zoo trouw in het praesteeren van diensten zonder loon aan de hofslaven, omdat zij steeds begrijpen, dat zij zich niet gelijk mogen stellen met de ,ataribolang”. Onder deze slaven namen dan de concubines, de zoogmoeders, zoogbroeders en zoogzusters van vorstelijke personen nog een afzonderlijke plaats in. Men zag hen vaak huwen met groote staatsie en dikwijls werden zij behandeld alsof zij van adel waren.

\section{$\mathrm{X}$.}

Mochten de slaven al geminacht zijn, de behandeling, die zij ondervonden moet, voorzoover ik heb kunnen nagaan, niet slecht zijn geweest. Sommigen woonden in bij den meester, anderen - zij, die zich onderscheiden hadden of zij, die groote gezinnen hadden gevormd - mochten afzonderlijk wonen. De eersten deden alles wat er te doen viel in huis : rijststampen, koken, waterhalen, hout hakken, kinderen zogen, kincleren verzorgen, masseeren, spinnen, garens verven, weven, manden vlechten, - en daarbuiten: gronden bewerken. zaaien, uitplanten en poten der gewassen en oogsten. $\mathrm{Zij}$ kregerı daarvoor niet minder te eten dan de gewone vrije en hun kleeding toonde met dezen geen verschil. Bij degenen, die afzonderlijk woonden, waren er vaak, die niet meer voor hun meester behoefden te werken, doch slechts bij bijzondere gelegenheden als besnijdenis, huwelijk of overlijden werden opgeroepen. Deze slaven hadden een

1) Adatrechtbundel XXXI, blz. 223 noot. 
goed leven en hen noemde de Boeginees dan ook „Ata manjamĕng”, de ,slaven, die het aangenaam hebben”.

\section{XI.}

De slaven waren rechteloos. Het voornaamste recht der vrijen, het beschikkingsrecht over den grond, was voor hen niet weggelegd. Een slaaf kon hoogstens de opbrengst genieten van den grond, waarover een ander, een edelman of een vrije, het erfelijk individueel bezitsrecht had verworven. Evenmin kon de slaaf ooit een of ander goed het zijne noemen. Al, wat hij gebruikte, was van den meester : het huis, waarin hij woonde, het bootje, waarin hij ter vischvangst ging en de pot, waarin hij zijn rijst kookte. Zijn dochter werd, zoo de meester dit wenschte, diens bijzit. In het Makassaarsch bestaat een bekende spreuk, die voor vorsten en hoofden gebruikt wordt, - vaak in toespraken, waarin trouw en aanhankelijkheid wordt gezworen -, en die luidt: „Pipi pipina, batang batanna” d.w.z. ,de tak, de uitwas is het zijne, de stam is het zijne." Kooreman vermeldt dit gezegde met betrekking tot de verhouding tusschen meester en slaaf en noemt dan ook als figuurlijken zin: ,,al, wat de slaaf bezit, is eigendom van zijn meester."

De slaven werden niet als leden van welke territoriale groep ook beschouwd. $Z_{\text {ij }}$ hadden niet de rechten, doch evenmin de verplichtingen van de vrijen, d.w.z. dat zij niet ,kasoewiyang”-plichtig waren.

$Z$ ij stonden enkel en alleen onder de bevelen van hun heer, zoodat geen hoofd eenig gezag over hen kon uitoefenen. Van het kiesrecht ten aanzien van de over hen gestelde hoofden, dat de vrijen overal in een of anderen vorm bezaten of bezeten hadden, waren de slaven uitgesloten. In de dorpen Mangasa, Pandang-Pandang, Bontobiraëng, Padjaipao en Malangkeri, alle in de onmiddellijke nabijheid van Djongaja, de voormalige residentie van de vorsten van Gowa gelegen, woonden zeer vele slaven. De ,taoe-maradeka” dier dorpen hadden geen hoofden, doch stonden rechtstreeks onder den vorst van Gowa zelf; de slaven stonden echter onder hun meesters.

De slaven konden zich slechts vrijkoopen, indien de meester dit toestond. Het is mij niet gebleken, dat het op dit punt eenig verschil maakte of zij erfslaaf dan wel ,nieuwe" slaaf waren. Mallinckrodt vermeldt echter in zijn aanteekeningen voor Mandar, dat slechts de ,,nieuwe" slaven zich konden vrij koopen. Hij noteerde de uitdrukking: „Mapoleang alawenna, malapassi alawenna": „door eigen schuld zijn zij gekomen, zij zelf hebben zich verlost." 
Erfslaven mochten niet vervreemd worden, „nieuwe” slaven wel.

Het is met deze onderscheiding van erfslaven en ,nieuwe” slaven, die wij reeds in hoofdstuk I, bij de behandeling van de indeeling in standen leerden kennen, een eenigszins moeilijk geval. De definitie, die Boeginees of Makassaar steeds voor erfslaaf, dus ,ata mana", ,ata sossorang”, ,ata poesaka” of ,batoewa sasorang” zal geven is deze: dat deze slaven van ouder op ouder slaaf zijn geweest.

Voert men hiertegen aan, dat de nazaten van de ,nieuwe" slaven op deze wijze ook eenmaal erfslaven moesten worden, dan wordt dit toegegeven. Zekerheid hieromtrent heb ik niet. Ik veronderstel echter dat sommige ,nieuwe" slaven erfslaven moesten worden, omdat zij bij rechtelijke uitspraak, tot in het zevende geslacht, bijvoorbeeld, met vrouw en kinderen tot slavernij waren veroordeeld. Ook de geroofde of van krijgstochten medegebrachte slaven zullen van den beginne af aan wel als erfslaven gedoodverfd zijn geweest. Vermoedelijk zijn het diegenen, die zichzelf als slaaf hadden verkocht teneinde boete of schuld te voldoen, geweest, wien in de practijk werd toegestaan zichzelf vrij te koopen of door familie te laten vrij koopen. De „Latowa” wijst ook in die richting. De meester moest dit echter uitdrukkelijk toestaan.

Maakten slaven zich verdienstelijk, dan werd hun soms de vrijheid geschonken. Lang niet altijd maakten de vrijverklaarden evenwel van hun vrijheid gebruik en het moet herhaalde malen zijn voorgekomen, dat oude slaven en slavinnen maar liever in het huis van hun meester bleven. Matthes vermeldt in zijn „Bijdragen tot de Ethnologie enz.” ${ }^{1}$ ) dat volgens de adat de slavin, die tijdens de bevalling van een adellijke vrouw het bloed opvangt onder het huis, vrij wordt.

Van vrijkoop of vrijverklaring moest door den meester kennis gegeven worden òf aan den rijksraad, òf aan den vorst zelf, ò aan het hoofd. Mallinckrodt teekende voor Mandar aan, dat vrijkoop geschiedde ten overstaan van den ,kali”, den hoogsten Mohamedaanschen godsdienstbeambte, die dezen vrijkoop dan moest melden aan den rijksraad, die op zijn beurt hiervan weer mededeeling deed aan den „Maradia”.

In vrijkoop of vrijverklaring waren vrouw en kinderen slechts begrepen, żoo dit uitdrukkelijk door den meester werd gewenscht.

De „Latowa” verbindt aan vrijkoop en vrijverklaring een aantal voorwaarden. Ten eerste mag de gewezen slaaf nimmer naar de hand dingen van een familielid van zijn vroegeren meester. Ten tweede

1) Blz. 499. 
mag hij zich nooit in rang verheffen boven zijn vroegeren meester en diens familie. Ten derde mag hij of een zijner afstammelingen niet in rechten optreden tegenover zijn gewezen heer of diens familie. Ten vierde mag hij noch een zijner nakomelingen zich met de voeten naar zijn vroegeren meester of diens afstammelingen gericht te slapen leggen. Ten vijfde mogen hij en zijn nakomelingen zich niet bovenstrooms van zijn gewezen heer of diens nazaten baden. Bij overtreding van een dezer voorwaarden wordt hij en zijn nageslacht weer tot den slavenstand teruggebracht. Daartegenover staat, dat de heer belooft: ten eerste, den gewezen slaaf niet uit zijn slaap te wekken; ten tweede, hem geen bevel te geven om het een of ander te doen, zoo hij, de gewezen slaaf, er geen lust in heeft; ten derde, hem niet te verbieden zich hier of daar heen te begeven en ten vierde, hem niet te beletten het een of ander te doen, indien dit althans iets behoorlijks is.

\section{XII.}

Indien iemand zich schuldig had gemaakt aan daadwerkelijk verzet tegen het gezag, dan kon hij tot ,ata kalompowang” (Mak.) of ,,ata aradjang" (Boeg.) worden gemaakt. Zij werden als het ware aan de rijkssieraden toegevoegd als slaaf en dienden dus den vorst of het hoofd zelf.

Kooreman vermeldt ${ }^{1}$ ), wat mij niet bekend was, dat slavinnen, die door haar meesters gedwongen werden om aan hun lusten te voldoen, en zich onder - d.w.z. onder de hoede van - het ornament stelden, ,ornamentsslavinnen" werden, zoodat haar meesters geen recht meer op haar hadden.

\section{XIII.}

De slavernij is op Zuid-Celebes verdwenen, doch vaak kan men tusschen adellijke families en geringen een merkwaardig hechten band constateeren. Bij de voorbereiding van en tijdens feesten, ziet men deze lieden in grooten getale opkomen om te helpen; zij toonen een groote verknochtheid en gaan voor de leden dezer families door het vuur. In de woningen van deze adellijke families treft men ook vele geringe mannen en vrouwen aan, die het mindere werk doen. Het grootste gedeelte dezer lieden zijn slaven van afkomst, die zich aan de oude meesters voor altijd verbonden gevoelen.

1) „Feitelịke toestand enz.”, Ind. Gids, 1883, I, 177. 


\section{VIJFDE HOOFDSTUK.}

De verhouding der standen ten opzichtevan e $1 \mathrm{k}$ a nder.

I.

Het sociaal aspect dezer verhouding.

Thans zijn wij gekomen aan een zeer belangrijk element in de standenstelsels van Zuid-Celebes, dat zich uit op wel het voornaamste aller gebieden van aanraking tusschen de verschillende standen: het gebied van het huwelijk.

In beginsel zijn de standen endogaam, dit wil zeggen, dat men een man het liefst een vrouw van gelijke geboorte geeft. Vooral in de hoogste groep en in de hoofdengeslachten wordt daarop meestal streng gelet. Komt men in de lagere tusschenstanden, dan ziet men vaker vrouwen uit lageren stand als eenige echtgenoote, dan in de groep der zuivere vorstentelgen. In Gowa ontmoette ik in deze groep een merkwaardig gebruik, uitvloeisel van een sterk endogamisch beginsel, namelijk het huwelijk middels plaatsvervanging. Een ,ana'tino" " $\left(\mathrm{A}^{1} \mathrm{I}\right)$ laat dan een volgeling huwen met een door dezen ,,ana'tino" begeerde vrouw. Na de huwelijksvoltrekking door den Mohamedaanschen godsdienstambtenaar verdwijnt de wettige echtgenoot van het tooneel en neemt de ,ana'-tino' " zijn plaats in. Zou de ,,wettige" echtgenoot als zoodanig betrapt worden, dan zou hij in vroeger jaren ongetwijfeld des doods schuldig zijn geweest en zonder vorm van proces zijn afgemaakt.

Onder endogamie versta $\mathrm{ik}$, wellicht ten overvloede merk ik dit hier op, niet dat een man het liefst moet huwen in zijn groep, die in de hoogste standen tevens zijn geslacht is, doch de wenschelijkheid om te huwen in een groep, die even hoog is als de zijne. Dit kan, om een voorbeeld te geven, voor een Gowaschen ,ana'-tino" " zijn eigen groep, dus zijn eigen geslacht zijn, doch het kan ook uit de hoogste groep van een ander vorstenhuis zijn, dat hij zijn bruid kiest. Zoo zijn langzamerhand meer of minder sterke banden ontstaan tusschen het vorstenhuis van Gowa en de regeerende geslachten van Sanrabone, Bantaëng, Barroe, Sidenreng, Bone, Wadjo' en Soppeng. Zoo was het mogelijk, dat in 1931 de voormalige Gowasche kroonprins, Mappanjoeki, den Boneschen troon besteeg. Zijn grootmoeder 
van moederszijde was een vorstin van Bone, zijn grootmoeder van vaderszijde een vorstin van Barroe, terwijl zijn eerste, thans reeds overleden, gemalin een Sidenrengsche prinses was.

Men ziet soms, dat een ,,ana'-tino," jarenlang een verbintenis heeft met een vrouw van minderen stand, van die vrouw en de uit die verbintenis geboren kinderen houdt en niet de minste neiging vertoont on nog een huwelijk in zijn stand te sluiten. Toch zal in de meeste gevallen de familie overwinnen en hem tot zulk een huwelijk weten te brengen.

De kinderen uit een huwelijk middels plaatsvervanging zijn uitgesloten van successie en erfrecht. Het bloed erven zij echter wel, zoodat zij komen te behooren tot een groep hooger dan die hunner moeder en lager dan die van hun vader. Zoolang ik in Gowa gediend heb, ben ik vervolgd door een zoon van een ,ana'-tino' " en een vrouw van geringen stand. Ik herinner mij nog zijn naam: Bidoella daëng Pabali. Hij wilde niet rusten, alvorens zijn recht op een aandeel in de nalatenschap zijns vaders was erkend. Het punt, waar alles om draaide, was dit: had zijn vader werkelijk een huwelijk aangegaan met Bidoella's moeder of was het een huwelijk middels plaatsvervanging geweest? $\mathrm{Na}$ onderzoek bleek ten slotte, dat dit laatste het geval was geweest, en Bidoella's eisch moest door de Inheemsche rechtbank worden afgewezen. Het is niet onmogelijk, dat dit huwelijk midclels plaatsvervanging ook elders op Zuid-Celebes voorkomt. Ik heb het slechts in Gowa en daar bij den hoogsten stand, ontmoet.

De hoofdengeslachten zijn in denzelfden zin in beginsel endogaam. Ook daar worden huwelijken in de eigen groep of in groepen van gelijken rang het wenschelijkst geacht. In sommige streken mag het hoofd niet op de wijze als door de adat is voorgeschreven, worden geinvesteerd, als hij niet met een vrouw van gelijken stand is gehuwd.

In den stand der vrijen wordt in het algemeen door ouders en naaste familie gewaakt tegen het huwen van een jongeman met een meisje, dat slavenbloed heeft. Een huwelijk van een meisje met een man van hoogeren stand, in Gowa al of niet middels plaatsvervanging, ziet men bij de vrijen over het algemeen gaarne. Slechts in één dorp, het grootste van Bone, Welado, vond ik een volstrekte uitsluiting van huwelijken van meisjes uit dat dorp met jongemannen van adel, op grond van de slechte behandeling, die, in lang vervlogen dagen, een meisje uit Welado in een huwelijk met een Boneschen prins had ondervonden.

In beginsel zijn de standen dus endogaam. In beginsel, daar de 
endogamie niet zoo streng is, dat man of vrouw niet in een andere groep, dan waaruit zij stammen, zou mogen huwen. Doch hier ontmoeten wij een belangwekkende beperking.

Aan het einde van het eerste hoofdstuk zeide ik, dat eenige opvallende eigenschappen der besproken standenstelsels, die reeds te constateeren waren aan de daar gegeven schema's, stilzwijgend waren voorbijgegaan, doch in de volgende hoofdstukken uitvoerig zouden worden besproken.

Beschouwen wij de šchema's in Hoofdstuk I nogmaals, dan zien wij daar geen rekening gehouden met de mogelijkheid van menging der standen door verbintenissen van vrouwen met mannen uit een lagere groep. Dit houdt verband met het feit, dat het huwen van een vrouw met een man uit een lagere groep ten strengste verboden is. In de hoogste standen wordt vóór het tot stand komen van een verloving altijd pijnlijk nauwkeurig nagegaan, of de man wel even hoog is als de vrouw.

Geslachtelijke omgang tusschen een vrouw van hoogen stand en een man van lageren stand is een der ernstigste misdrijven, die de Boegineesche en Makassaarsche samenleving kent. Het is een misdrijf, waarvan niet één of enkele individuën schade zullen ondervinden, doch men neemt aan, dat, evenals tengevolge van incest, allerlei onheil als misoogst, natuurrampen en besmettelijke ziekten de geheele gemeenschap zullen treffen. De straf was dan ook, vóór de Nederlanders hun invloed konden aanwenden, zeer zwaar. In Gowa paste men dan ook dezelfde straf toe, als die op bloedschande stond: de schuldigen werden in een zak genaaid en aan den mond van Gowa's grootste rivier, de Berang, in zee geworpen. Ik vermoed, dat deze straf slechts bij hooge uitzondering behoefde te worden toegepast, omdat het niet spoedig zoover komt. De adellijke vrouw, die haar hart verliest aan een man van minderen stand, verraadt zich al spoedig en het vermoeden van het bestaan van een flirtation is reeds voldoende voor haar naaste mannelijke familieleden om naar de badik te grijpen. Als de man in het spel dan niet zorgt bijtijds het land te verlaten, is hij zijn leven niet meer zeker.

Mallinckrodt vermeldt in zijn nagelaten aanteekeningen, dat in Mandar alleen de man werd ter dood gebracht. Deze mocht dan niet dusdanig worden gedood, dat zijn bloed de aarde bezoedelde. Het voornemen tot een huwelijk van een vrouw met een man van minderen stand wordt, naar Mallinckrodt noteerde, in Mandar genoemd: „mati temei poena lambe” d.w.z. ,urineeren tegen een boom, waar- 
aan goederen hangen," wat de beteekenis zou hebben van ,dingen doen op plaatsen, die daartoe niet bestemd zijn."

Onder Westerschen invloed werden de straffen op dit misdrijf milder. $\mathrm{Na} 1906$ is niemand meer op Zuid-Celebes daarvoor ter dood gebracht. De straf op dit delict daalde in een kwart eeuw van levenslange verbanning via twintig- en tienjarige tot vijfjarige verbanning. Ik kreeg zeer sterk den indruk, dat vooral de hoogere standen dit misdrijf, althans tegenwoordig, heel wat ernstiger opnemen dan het gewone volk. De vrouw kan in de meeste gevallen na het verstrijken van de verbanningsperiode niet in den familiekring terug keeren. $\mathrm{Zij}$ is en blijft uitgestooten. In haar eigen groep en ook in de daarmede overeenkomende groepen in andere streken wordt zij niet meer opgenomen, zoodat zij zakt naar den stand der vrijen. D€ man wordt bij terugkomst door magen en verwanten met open armen ontvangen en is weer vrij man, al doet hij verstandig ter vermijding van onaangename voorvallen, in verband met het uitermate opvliegend karakter van Makassaren en Boegineezen, zich eenigszins afzijdig te houden van de groep, waartoe de vrouw heeft behoord. In ballingschap kunnen de twee geen huwelijk sluiten, daar ieder een andere streek krijgt aangewezen als verbanningsoord. Ik wil niet zeggen, dat ook de bevolking in het algemeen dit misdrijf niet verafschuwt, doch in den huidigen tijd reageeren de hoogere standen hierop het sterkst.

Toch worden bij uitzondering wel huwelijken gesloten, waarbij de man lager in stand is dan de vrouw, doch man en vrouw mogen dan niet al te veel in stand verschillen. In Mallinckrodt's aanteekeningen vind ik vermeld, dat een ,taoe pea nae"-man (B I a) kan trouwen met een ,poewasasigi"'-vrouw (A IV), doch slechts wanneer hij een veel hoogeren dan den gebruikelijken bruidschat betaalt. Geheel op het niveau van de vrouw komt hij daardoor niet, daar de uit zulk een huwelijk geboren kinderen tot de „poewa si parapa” (A V) gerekend worden en ten opzichte van de moeder dus in stand achteruitgaan. Matthes ${ }^{1}$ ) spreekt terloops ook over gemengde huwelijken: „Doch waarop bij deze volken inzonderheid gelet wordt, is dat eene vrouw van hooge geboorte niet trouwe met een man van geringen stand, hetgeen vooral afgekeurd wordt, wanneer die man haar eigen slaaf is." Het is waarschijnlijk, dat Matthes zich niet bewust is van het feit, dat huwelijken als waar hij over schrijft, eigenlijk onbestaanbaar zijn. Van ,afkeuring, ingeval een vrouw van hoogen stand haar eigen

1) Matthes, „Bijdragen tot de Ethnologie van Zuid-Celebes”, 's-Gravenhage, 1875, blz. 13 . 
slaaf huwt" mag dan ook nimmer gesproken worden. In de eerste plaats, wijl dit niet afkeurenswaardig, doch misdadig is, een gruwel, en in de tweede plaats, omdat er geen personen te vinden zouden zijn, die toestemming zouden willen geven tot een dergelijk huwelijk, laat staan personen om een dergelijk huwelijk te sluiten. De plaats in de „Latowa”, waaraan Matthes zijn wetenschap moet ontleenen, spreekt ook in het geheel niet van een ,huwelijk" tusschen een vrouw van hooge geboorte met haar eigen slaaf, doch van geslachtelijken omgang tusschen deze beiden. Matthes zegt verder: „Alleen onder de Wadjoreezen, bij wie als echte handelaren het geld steeds een voorname rol speelt, is dergelijke verbintenis geoorloofd, mits de man voor 400 reyaal of $\mathrm{f} 800$ als 't ware edeler bloed koope, en hierdoor in rang gelijk worde aan de adellijke dame". Nu hebben de Wadjoreezen op Zuid-Celebes geen al te besten naam en zij heeten veel voor geld te doen. Mij zelf zijn in het geheel geen voorbeelden bekend van huwelijken tusschen vrouwen van hooge geboorte en mannen van geringe afkomst - en ik heb vrij wat huwelijken in de hoogste standen der Boegineezen en Makassaren tot stand zien komen --, doch dit bewijst nog niet, dat huwelijken met groot standsverschil in Wadjo' niet zouden hebben kunnen voorkomen. Wel heb ik, niet in Wadjo', echtparen ontmoet, waarvan men fluisterde, dat hij eigenlijk een tikje minder hoog bloed had dan zij, maar dat is dan ook het eenige. Ook weet ik, dat men in Wadjo' voor een verhooging van de huwelijksgift ten aanzien van het bloed van den man wel wat water in den wijn wil doen, doch ik kan onmogelijk aannemen, dat in Wadjo' een huwelijk tusschen een vrouw uit de hoogste standen en een slaaf, meer dan overal elders op Zuid-Celebes, bestaanbaar zou zijn. Ik acht in Wadjo' huwelijken als door Mallinckrodt voor Mandar vermeld, zeer wel mogelijk, doch een wijdere kloof in stand lijkt mij onoverbrugbaar.

Een vaak gering verschil in stand is dikwijls oorzaak, dat de ouders van een meisje hun toestemming aan een huwelijk onthouden.

$$
* * *
$$

In het bovenstaande werd steeds gesproken van en gedoeld op de vrouw uit de adelsgroepen en het uitermate strenge verbod van huwelijk en geslachrelijken omgang van deze vrouw met een man van lageren stand. Ook het huwelijk van een vrije vrouw met een slaaf was verboden, doch een onmogelijkheid was dit huwelijk niet. Het was geen misdrijf van dezelfde afschuwelijkheid als de geslach-

D1. 90. 
telijke omgang van een vrouw van hoogen stand met een man van geringe afkomst. Het bracht geen gevaar voor de gemeenschap mede. Het was afkeurenswaardig, de vrouw werd uitgestooten uit haar groep, doch uitgesloten was dit huwelijk geenszins. De vrouw, die met haar eigen of andermans slaaf huwde, werd gestraft met een boete. De man, die met eigen of andermans slavin huwde, in sommige streken eveneens.

$* *$

Tot welke groepen kinderen uit gemengde huwelijken behooren, werd uitvoerig uiteengezet in het eerste hoofdstuk en blijkt duidelijk uit de bij dat hoofdstuk behoorende schema's. Slechts één gemengd huwelijk vergt nog bespreking op dit punt en wel dat van een vrije met een slavin. In Gowa werd een vrouw door huwelijk met een vrije nog geenszins vrij. De vrije kon haar vrijkoopen, doch hij kon dat ook laten. In Bone was het evenzoo, terwijl in Mandar, volgens Mallinckrodt's aanteekeningen, bij een huwelijk van een vrije en een slavin ieder in eigen stand bleef. Dat dit invloed op den staat der kinderen had, is duidelijk. Hier duikt dan weer het principe van de kinderverdeeling op. Had de man, de vrije (in Gowa en Bone) de huwelijksgift, aan den meester der slavin, voldaan, dan waren de oneven kinderen slaven en de even kinderen vrijen. De eersten kwamen aan den meester der slavin. In Mandar, teekende Mallinckrodt aan, was in het geval de huwelijksgift onbetaald bleef, het derde kind alleen voor den vader, al waren er ook tien. Zulk een huwelijk werd ,poesoeng” = ,leeg” genoemd. In Bone en Gowa kwamen bij onbetaalden huwelijksgift alle kinderen aan den meester der slavin.

$* * *$

Gemengde huwelijken hebben op het erfrecht der kinderen geen invloed. Voor een slaaf erfde steeds de meester, dus voor kinderen uit een huwelijk tusschen een vrije en een slavin, die aan den meester der slavin waren toegevallen, eveneens.

$* * *$

De invloed van de gemengde huwelijken op de erfopvolgingsrechten der hieruit gesproten kinderen vond reeds behandeling ${ }^{\mathbf{1}}$ ).

$\mathrm{Op}$ de huwelijksgebruiken, die hier overigens geen uitvoerige behandeling zullen vinden, heeft de stand van het bruidspaar grooten

1) Blz. 479 e.v.; 501, 502. 
invloed. Essentieel verschil bestaat er tusschen de gebruiken der hoogste standen en die der laagste niet. De hoogste standen zijn of waren althans vroeger, tevens de standen, die het kapitaalkrachtigst waren. Deze omstandigheid drukte en drukt nog tot op zekere hoogte een stempel op de huwelijksgebruiken in de verschillende standen. De geschenken, die over en weer vóór en bij het huwelijk werden en worden gewisseld, namen en nemen toe in kwantiteit en kwaliteit naar gelang het bruidspaar hooger is in stand, zooals ook de feesten armelijk, sober, gewoon of pompeus zijn naarmate de partijen tot de laagste dan wel tot de hoogere en hoogste standen behooren.

Mijn bedoeling is hier voornamelijk de aandacht te vestigen op de huwelijksgift ${ }^{1}$ ), die in beginsel afhankelijk is van den stand der bruid. Heden ten dage heerscht nogal eenige verwarring op dit punt. In somnige streken heeft het Europeesch bestuur om een of andere reden zich met de huwelijksgift bemoeid, hetgeen vaak vertroebelend heeft gewerkt. Over het algemeen merkt men onder de lagere standen, voornamelijk in de kuststreken, - in de bergstreken is de bevolking conservatiever - een streven op, om een veel te hooge huwelijksgift te eischen en te betalen met het doel, zich daardoor meer aanzien te verwerven. Aan den anderen kant zijn de inkomsten van den adel, die in haar geheel leefde op kosten van den kleinen man, in de laatste kwarteeuw sterk achteruitgegaan, zoodat deze het geld mist, om zich door hooge huwelijksgiften en prachtige feesten even sterk van de lagere standen te onderscheiden als voorheen. Ook hier zien wij, als gevolg van het Europeesch bestuur, nivelleering optreden.

In Gowa bedraagt de hoogste huwelijksgift 80 realen of 160 gulden, te voldoen in rijksdaalders; deze huwelijksgift is gebruikelijk voor de ,ana'-tino'"'-vrouw ( $\left.\mathrm{A}^{1} \mathrm{I}\right)$. De laagste was vroeger 8 realen, de huwelijksgift voor een slavin, soms zelfs 4 realen. Tusschen den hoogsten en den laagsten huwelijkgift vindt men er van 44, 40, 28, 20, 16 en 12 realen. De laagste huwelijksgift komt niet meer voor. De op één na laagste, die van 12 realen, vroeger gebruikelijk bij de „,taoe-samara”, komt nog zelden voor.

Matthes vermeldt ${ }^{2}$ ), zooals immer zonder bronvermelding, doch hoogstwaarschijnlijk op grond van een hem bekend handschrift, dat

1) Onder huwelijksgift, Mak. „soenrang”, Boeg. „sompa”, versta ik slechts het bedrag in geld, dus niet de andere geschenken, die door den bruidegom aan de bruid vóór het huwelijk worden gegeven.

2) Matthes, „Bijdragen tot de Ethnologie enz.”, blz. 16. 
in oude tijden de voornaamste huwelijksgift was de ,sompa to-Sĕlli”, aldus genaamd naar Sĕlli, een in den hemel gelegen land, als zijnde de huwelijksgift van den eersten uit den Hemel gedaalden vorst van Loewoe', met name Simpoeroesiya. „Deze thans”, zegt Matthes in 1875, ,geheel in onbruik geraakte huwelijksgift bedroeg 100 kati goud, of 8000 reyaal d.i. f 16.000 ".

„Daarop volgde de ,,sompa-leba”, waarschijnlijk zoo veel als vorstelijke huwelijksgift, naar het oud- Boegineesche „to-leba”, vorst, ten bedrage van 50 kati goud, of 4000 reyaal, d.i. f 8000 .

Voorts kwam de ,sompa-Loewoe'”, of Loewoe'sche huwelijksgift aan de orde, van minstens 10 kati en 10 taï, of 880 reyaal, f 1760 , doch ook meer.

Eindelijk had men eertijds nog de ,sompa oedjoeng-adjoe”, welke nooit meer dan 10 kati en 10 tai, of 880 reyaal, dat is : f 1760 , bedroeg, en op verre na niet van zooveel geschenken vergezeld ging, als bij de andere vorstelijke huwelijksgiften gewoonlijk het geval was....

De huwelijksgift van een Loewoe'sche of andere voorname vorstin” (Matthes bedoelt ,voor een Loewoe'sche of andere vorstin”) bedraagt thans (1875) niet meer dan 3 Kati en 3 tai, of 264 reyaal, dat is: $\mathrm{f} 528$, en dikwijls slechts 1 kati en 1 tai, of 88 reyaal, d.i. f 176 en 88 duiten.

Op deze laatste huwelijksgift volgen successievelijk die, welke onder prinsen en andere inlanders van minder rang gebruikelijk zijn, als van 44 reyaal, d.i. : f 88 , van 22 reyaal, d.i. : f 44, van 20 reyaal, d.i. : $\mathrm{f} 40$ en van 12 reyaal, d.i. : $\mathrm{f} 24$ ".

In den reeds genoemden brief van den heer Van Rhijn ${ }^{1}$ ) bespreekt deze de in Wadjo' gebruikelijke huwelijksgiften. Ik laat den inhoud van dat gedeelte hier volgen.

1. Sompa botjo ${ }^{2}$ ). Deze was verschuldigd, als de vorst zelf huwde met een regeerend vorstin van even hoogen stand of met een vrouw, die zelf geen regeerend vorstin was, doch van even zuiver bloed, en uit een even voornaam vorstenhuis afkomstig was als de vorst zelf. De „sompa” bedroeg dan 14 kati ,doewi'-lama” (oude duiten); 1 kati is 88 reaal, 8 oewang, 8 doewi', 1 slaaf en 1 karbouw ; 1 reaal $=$ f 2 . - , 1 reaal bevat 24 oewang of 240 doewi', 1 slaaf $=40$ reaal

1) Blz. 452 .

2) „Botjo”, gebezigd om de groote staten van Zuid-Celebes aan te duiden. „Telloempotjowé” is de naam voor de drie verbonden mogendheden van Bone, Wadjo' en Soppeng. 
en 1 karbouw $=25$ reaal. De ,sompa" bedraagt dus in guldens uitgedrukt f 4294.- - Behalve deze ,sompa” was de vorst verplicht drie maanden lang dagelijks sieraden of doeken van waarde aan zijn toekomstige schoonouders te laten brengen, tenminste als dit financieel zijn krachten niet te boven ging.

De waarde dezer goederen kan geschat worden op driemaal de waarde der ",sompa”, dus op rond f 12.000.- . Hier staat wel een tegengeschenk tegenover, doch de waarde hiervan is niet hooger dan f 2500.-. Aan deze ,sompa" zou onderworpen zijn een Aroempone (vorst van Bone), een Datoe Loewoe', een Datoe Soppeng en een Aroe Matowa van Wadjo'.

2. Sompa ana'botjo. Deze bedroeg 7 kati ,doewi'-lama” dus f 2147 en was verschuldigd, als een ,,ana'botjo", een kind van een vorst van een der voornaamste staten van Zuid-Celebes dus, huwt òf met een ,ana'botjo" òf met een andere vrouw van even hoog bloed. Het ge-durende drie maanden geven van geschenken is niet noodig. In onderling overleg wordt één keer een geschenk gegeven ter grootte van $f$ 3500.- tot $f$ 5000.- Doch hiertegenover staat van de zijde der vrouw een tegengeschenk van nagenoeg dezelfde waarde.

3. Sompa kati. Deze bedraagt 5 kati ,doewi'-real ${ }^{1}$ )-ajam” (haantjesduiten). Onder 1 kati wordt verstaan 88 reaal 8 oewang en 8 doewi' en 1 slaaf. In Wadjo' behoort er geen karbouw bij, in Bone en Soppeng wel; 1 ,real-doewi'-ajam” is gelijk aan f 0.60 , 1 slaaf $=$ 120 realen. De ,sompa” bedraagt dus 1045 realen of f 627.-. Deze „sompa” is verschuldigd als een „Ranrang”; of „Baté” of diens kinderen volgens hun stand huwen. „Ranrang” en „Baté” zijn de titels van de voornaamste vorsten van Wadjo', die onmiddellijk onder den hoofdvorst staan.

4. Sompa ana'-matola. Deze bedraagt 3 kati „,doewi'-real-ajam”, dus 627 reaal of $\mathrm{f} 376.20$. $\mathrm{Zij}$ is verschuldigd voor ,ana'-matola”vrouwen (A I) of ,ana'-sangadji"-vrouwen (A II), die niet den titel van „Ranrang” of „Baté” dragen.

5. Sompa radjĕng (A III), welke 2 kati bedraagt.

6. Sompa tjera-sarei (A IVa), van 1 kati. Volgens de adat zou de „sompa" van de volgende standen nu geleidelijk moeten dalen, doch de ,anakaroeng” schamen zich, - - voigens de zegslieden van Van Rhijn althans - om van te lagen stand blijk te geven en betalen daarom meestal de ,sompa tjera-sawi”.

1) Ook „rella” = real (Port.), hetzelfde als ,Spaansche mat”. 
7. Sompa taoe-detjeng (C I) bedraagt $1 / 2$ kati, 44 reaal practisch. f 27.50. Een slaaf wordt hierbij niet medegerekend. Deze „sompa” wordt door den gezeten burgerstand betaald.

8. Sompa taoe-maradeka (D) bedraagt 1/4 kati, 22 reaal of zes rijksdaalders.

Bij de laatstgenoemde drie "sompa's” is de waarde aan geschenken, die de man aan de vrouw behoort te geven, grooter dan die van de „sompa" zelf. Bij de laatste ,sompa” bedraagt de waarde dezer geschenken ongeveer $f$ 60.-

Ook een „sompa” van 12 realen of 3 rijksdaalders komt bij mindere menschen voor, terwijl degenen, voor wie ook dat bedrag te hoog is, niets betalen. In sommige streken, zooals Peneki is de „sompa” steeds minstens 22 realen. Zij, die deze „sompa” betalen, moeten echter in stilte, zonder plechtigheden, trouwen. Men mag bij voorbeeld den bruidegom niet in optocht naar de bruid brengen. Van Rhijn laat dit verder, als voor hem niet ter zake doende, zonder commentaar, doch hierachter voelt men de hoofden, die een zekere som naar rato van de ,sompa" voor ieder huwelijk ontvangen.

Op politiek gebied is de verhouding der standen, zooals ternauwernood nog behoeft te worden gezegd, dusdanig, dat de adel regeert over de vrijen. Doch als wij het zuiver politiek gebied verlaten en het woord adel in zijn uitgebreidsten zin nemen en het woord regeeren eveneens, als wij het dus zoo zeggen: de adel wordt door het gewone volk gediend en gehoorzaamd, ook dan zeggen wij de waarheid. Voornamelijk hier zijn de verhoudingen overigens aanmerkelijk veranderd, zijn de tegenstellingen vooral na 1906 verzacht, doch toch geldt nog steeds ten volle wat Kooreman in 1883 schreef $^{1}$ ) : „Onder Makassaren is het een vaste regel, dat gelijken in geboorte over elkaar slechts weinig, en lageren over hoogeren geen gezag kunnen uitoefenen". Vroeger hadden hoogeren over lageren alles te zeggen en tegenwoordig nog zeer veel. Steeds weer blijkt dit. Als iemand door het Europeesch bestuur aan het hoofd van een gemeenschap wordt gesteld en hij is de gelijke in bloed van de onder hem gestelde hoofden der kleinere gemeenschappen, dan zal hij weinig gezag hebben. Is hij de mindere, dan zal hij geen gezag hebben. In Limboeng, een land, dat sinds menschenhengenis onder Gowasche suprematie is ge-

1) Kooreman, ,,De feitelijke toestand enz.”, Ind. Gids, 1883, I, blz. 191. 
weest, en dat bestaat uit een veertigtal kleine gemeenschappen, waarvan de inwoners zich voor het grootste deel eigenlijk geen Gowareezen voelen, kwam de onderworpenheid van den Makassaar aan al wat van hoogen adel is, duidelijk naar voren, toen de mogelijkheid werd overwogen aan het hoofd van geheel Limboeng een „karaëng” te stellen. Al deze kleine gemeenschappen hadden hoofden van lagen rang, die, ondanks dat, sedert het begin van de twintigste eeuw een zekere onnatuurlijke zelfstandigheid hadden bezeten. Tevoren waren zij altijd verantwoording schuldig geweest aan Gowasche prinsen, die deze gebieden in apanage bezaten, doch toen de apanages vervielen, verviel tegelijkertijd het gezag, dat deze hoofden boven zich behoorden te hebben. Daar in den grond Limboeng als een eenheid kon worden beschouwd en de hoofden gaarne een ,karaëng” boven zich zagen, werd overwogen een Gowaschen prins als zoodanig aan te stellen, daar het geslacht, waaruit deze ,karaëng” eigenlijk verkozen moest worden, reeds uitgestorven was. Toen ik de plannen met deze hoofden besprak, bleek echter, welk een haat de eeuwenlange Gowasche onderdrukking tegen het Gowasche vorstengeslacht in het leven had geroepen. Zij vreesden knevelarij en tyrannie en hoe ik ook betoogde, dat de tijden veranderd waren, niets hielp. Ten slotte zeide ik hun, dat het, volgens mij, toch het eenvoudigste ter wereld zou zijn om mij, in geval van machtsmisbruik, daarvan onmiddellijk in kennis te stellen. Daarop kreeg ik het merkwaardige antwoord: „Mijnheer, wij kennen ons zelf, wij zijn Makassaren. Staat eenmaal de Gowarees hier weer aan het hoofd, dan zullen wij zwijgen en ons niet verzetten, wat hij ook doet". Deze uiting is typeerend voor de verhouding, waarin het gewone volk tot den adel staat. Vandaar dan ook dat het mogelijk is, dat één of meer ,,anakaraëngs" aan het hoofd staan van een organisatie van veedieven ${ }^{1}$ ) en als bendeleiders ruime inkomsten genieten, zonder dat ooit voldoende bewijsmateriaal tegen hen kan worden verzameld. $\mathrm{Zij}$ worden blindelings gehoorzaamd en vrijwel nimmer verraden. Zoo zijn ook dobbelpartijen, waaraan lieden van adel meedoen, uiterst moeilijk op te sporen. In Gowa heb ik een vorstentelg, een hoogen ,ana'-sipoewé”, gekend, waarvan men fluisterde, maar dan ook alleen fluisterde, dat hij de intellectueele dader van eenige moorden was en de aanstichter van ontelbare vee-

1) Veediefstal is een uitermate populair misdrijf onder de Boegineezen en Makassaren. Het wordt beschouwd als een opwindende sport. Er zijn streken, waar een man niet roor vol wordt aangezien, zelfs geen vrouw kan krijgen, als hij nog nooit vee heeft gestolen. 
diefstallen. Toen hij, na een leven van dobbelpartijen, knevelarijen, vechtpartijen, verkrachtingen en verleidingen, doodgestoken werd, slachtte men in Gowa allerwege kippen uit dankbaarheid van een dergelijken bruut verlost te zijn. Hij kon in zijn geheele leven niet dan voor eenige onbelangrijke feiten strafrechtelijk vervolgd worden. Een ieder zweeg als het graf, want zijn bloed was blauwer dan dat van één van de hoofden in Gowa, degenen, die gaarne in de beschermende schaduw van zulk een gevreesd man leefden, waren velen en de dolken van hem en zijn volgelingen kwamen sneller uit de scheede naarmate hun optreden meer succes had.

Dit alles zouden wij illustraties van den verkeerden kant der politieke verhouding tusschen adel en volk kunnen noemen.

Keeren wij thans, nu wij gezien hebben tot welke anti-sociale verschijnselen het gezag van het bloed kan leiden, terug naar de verhouding op zuiver staatkundig terrein.

Wij zien dan, naast dit groote gezag, de macht van vorsten en hoofden op verschillende wijzen beperkt. Alle vorsten en hoofden werden ${ }^{1}$ ) verkozen door bepaalde kiesheeren. Deze kiesheeren werden zelf in vele gevallen weer verkozen door hun kiesheeren, welke laatsten dan op hun beurt òf door hun kiesheeren òf door de oudsten uit hun gemeenschap werden verkozen. In de hoofdstukken II en $\mathrm{III}^{2}$ ) zagen wij reeds, dat deze verkiezingen in een zeker kader werken, doch dit doet niets af aan het feit, dat er in het regeeringsbestel een democratische inslag te bekennen is. Het woord democratisch klinkt wellicht wat vreemd in dit verband, omdat de kiesheeren in een rijk tot den, nà het vorstengeslacht, voornaamsten adel behooren. Doch in laatste instantie is toch een der zuilen, waarop deze zelfde kiesheeren steunen, de wil van het gewone volk. De wil van het volk vormt één der grootheden in de regeeringsorganisatie der Boegineezen en Makassaren. Geen alles overheerschende grootheid, vooral geen - behalve bij de verkiezing der lagere hoofden bewust werkende grootheid, doch één, die er even goed is als de persoonlijkheid van den vorst, als de persoonlijkheden van 's vorsten naaste raadgevers, als de persoonlijkheden der kiesheeren en als de persoonlijkheden der lagere hoofden.

Dat rijksgrooten, in Bone bijvoorbeeld de rijksbestierder, de opper-

i) Ik schrijf ,werden”. Tegenwoordig geldt een verkiezingsreglement, dat zeer verdienstelijk is, doch niet met de adat overeenstemt, hetgeen trouwens onmogelijk zou zijn.

2) B1z. 488, 490, 491, 511. 
bevelhebber en de kiesheeren met soms nog andere hoogwaardigheidsbekleeders, vorsten hebben afgezet, hebben wij gezien ${ }^{1}$ ). Eigenlijk behooren de kiesheeren dit te doen, doch wij kunnen aannemen, dat de voornaamste hoogwaardigheidsbekleeders en prinsen hieraan altijd hebben medegewerkt.

Op het gebied der justitie vooral -- behoef ik het te zeggen ? is onder Westerschen invloed wel zeer veel veranderd.

Ook hier teekende zich de indeeling der standen scherp af. Met gelijke maat werd niet gemeten. Het sterkste voorbeeld is wel dit: als, vóór 1906, en dit was, geloof ik, door heel het Makassaarsche en Boegineesche gebied adat, een vrije een vrije doodde, omdat hij dezen op overspel met zijn vrouw betrapte, dan was dat zijn recht. Als een vrije een ,anakaraëng” op overspel met zijn vrouw betrapte en hem doodde, dan mochten de volgelingen van dezen ,anakaraëng” het wedervergeldingsrecht toepassen. Als, evenwel, een ,,anakaraëng” een vrije, om welk kleine vergrijp ook, doorstak, dan mocht deze ,anakaraëng” niet gedood worden. Laag miste tegenover hoog het wedervergeldingsrecht. Deze adat leeft nu nog. De slechte elementen, die de adel kent, bedrijven van allerlei, dat het daglicht niet kan verdragen en dat een gewonen man al lang het leven zou hebben gekost. Doch de mindere, die zijn wapen opheft tegen zijn meerdere, is nog steeds een uitzondering. De leden der inheemsche rechtbanken, meestal tot den hoofdenadel, ook wel tot de vorstengeslachten behoorende, begeven zich slechts hoogst zelden en dan nog noode buiten den gedachtengang, dat het leven van een willekeurigen edelman heel wat meer waard is dan dat van den verdienstelijksten burger.

In de „Latowa”, die ook Boegineesche wetten bevat, vond ik eenige teekenende artikelen, die ik hier, vertaald, laat volgen.

1. „Indien een vrije een slaaf doodt, behoort de dader een zoengeld aan den meester van den gedooden slaaf te betalen, te weten voor een man 20 en voor een vrouw 30 realen."

2. „Indien vrije lieden oneenigheid krijgen en elkander met wapens te lijf gaan en één hunner wordt gedood, zoo behooren de verwanten van den gedoode, zoo zij den dader vatten, het wedervergeldingsrecht toe te passen; wanneer de dader naar het huis van den rechter vlucht, wordt de doode niet meer gewroken, doch moet de dader een zoengeld, groot 30 realen betalen."

1) Blz. 487,490 . 
3. „Indien een ,,anakaroeng” door een vrije wordt gedood en deze wordt gevat, zoo dient de ,anakaroeng" gewroken te worden; wanneer de vrije vlucht in het huis van den rechter, dan wordt de ,anakaroeng" niet meer gewroken en degeen, die den ,,anakaroeng" gedood heeft, slechts beboet met „,sikati sitai” (één kati één tai $=88$ realen van f 2.-). Als de dader dit zoengeld niet kan betalen, zoo kan dit op zijn vrouw en kinderen worden verhaald, aangezien hij iemand gedood heeft, die hooger is dan hij zelf."

4. „Als een vorst of een ,anakaroeng” een slaaf doodt, moet de dader een zoengeld betalen van 20 realen; al is de dader gevat, toch mag men den slaaf niet wreken."

5. „Indien een vorst of ,,anakaroeng” iemand doodt, zonder dat deze schuld heeft, dan is hij strafbaar met de helft van het zoengeld, dat betaald zou moeten worden, zoo men hem doodde, en bovendien het zoengeld voor den doode."

Vrijwel dezelfde artikelen komen voor in de „Verzameling Inlandsche Wetten", die Matthes publiceerde in zijn Makassaarsche Chrestomathie en Nederburgh ${ }^{1}$ ) vertaalde, en die wellicht ontleend zijn aan de „Rapang”, de IrIakassaarsche tegenhanger van de „Latowa”.

1). ch het standsverschil uit zich niet alleen in een jus talionis, dat niet geldt voor den mindere tegenover den meerdere. In de zooeven aangehaalde artikelen uit de „Latowa” bemerkten wij reeds, dat de verschillende standen verschillende zoengelden hebben. In de „Latowa” vinden wij de zoengelden (Boeg. ,tokkong”) opgenoemd, doch voor welk gebied deze golden, is niet duidelijk. In andere gedeelten van de „Latowa”, in wetsartikelen, worden andere zoengelden genoemd. Doch dit doet ook minder ter zake, daar het ons te doen is om het opsporen van het beginsel. Zoo vinden wij dan als "tokkong" voor een edelman, tevens hoogwaardigheidsbekleeder, „,sikati sitai” d.i. 88 realen. Voor een ,,anakaroeng”, geen waardigheid bekleedende, 7 tai of 56 realen. Voor een ,maradeka” $31 / 2$ tai of 28 realen en voor een slaaf $2 \frac{1}{2}$ taï of 20 realen. Eerdmans ${ }^{2}$ ) vermeldt voor Gowa voor ,adellijke personen” 88 realen, voor een vrije vrouw 40 realen, voor een vrijen man 30 realen, voor een slavin 30 realen en voor een slaaf 20 realen. In Gowa heet zulk een zoengeld ,sapoe-mate".

Ook in de boete, die werd opgelegd, werd met den stand van den dader rekening gehouden. In de ,.Verzameling van Inlandsche

1) Ind. Weekbl. van het Recht, No. 1292-1294, 1296.

2) Eerdmans, „Het Landschap Gowa”, blz. 76. 
Wetten" in de Makassaarsche Chrestomathie van Matthes, komt een afzonderlijk artikel voor, waarin gezegd wordt dat de boeten, die de rechter oplegt, de volgende zijn :

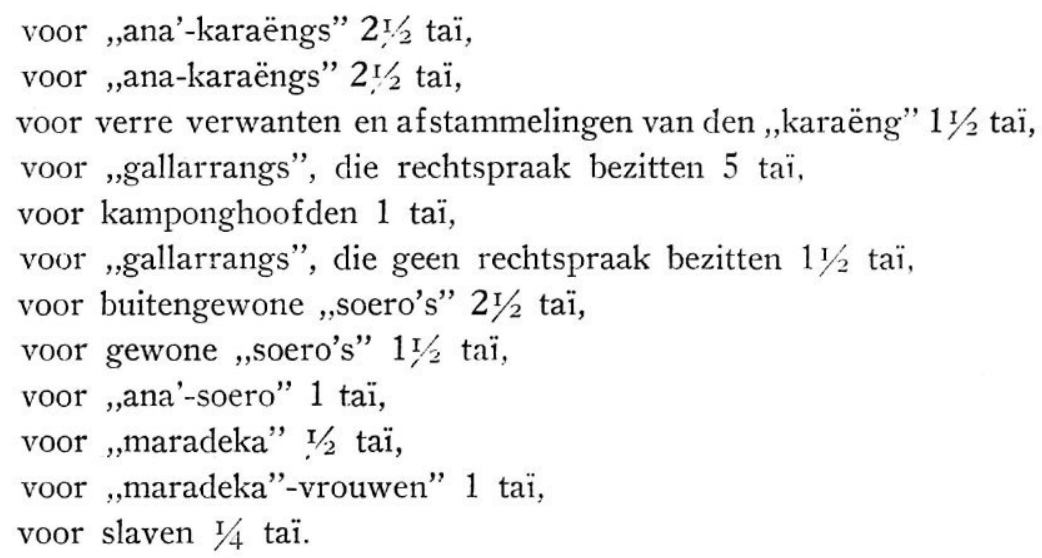

Waarschijnlijk geldt deze lijst voor Gowa, daar dan met de ,gallarrangs, die rechtspraak bezitten", de onmiddellijk onder den „karaëng”, den vorst van Gowa, staande hoofden kunnen worden bedoeld, met de ,gallarrangs, die geen rechtspraak bezitten" de onder dezen staande hoofden en met de kamponghoofden de laagste hoofden. „Gallarrang” is, zooals reeds bleek, een Makassaarsche titel. Hoewel de „Batesalapang”, de negen kiesheeren van Gowa, in vroegere tijden heel wat zelfstandiger zijn geweest, is de „Gallarrang”titel meer in overeenstemming met het peil, waarop hun waardigheid langzamerhand is komen te staan. De leden van het vorstenhuis noemen alle onmiddellijk onder den vorst gestaan hebbende hoofden, of zij den titel ,karaëng” dragen of niet, „Gallarrang” en hun stand den „Gallarrang-stand”.

"Soero's” waren afgezanten, boodschappers. Buitengewone „,soero's" waren van hoogen stand en belast met bijzonder gewichtige zendingen. „Ana'-soero” waren vermoedelijk de zoons, die den vader vaak vergezelden en beschermden op diens reizen als buitengewoon afgezant en tevens de zoons van de vaste ,,soero's”. Niet onwaarschijnlijk is het, dat de zoons van deze vertrouwenslieden van den hoogsten in den lande van lieverlede een positie zijn gaan innemen, die het wenschelijk maakte een aparte strafmaat voor hen vast te stellen.

De „Latowa” heeft een dergelijke lijst, die evenwel onvolledig aandoet. Het principe is hetzelfde: ook hier geen bevoordeeling van de hoogere standen, integendeel. Hoe hooger de stand, hoe hooger de 
boete. Overigens golden deze boeten niet voor alle delicten. In de wetten treft men herhaaldelijk artikelen aan, die voor bepaalde delicten bepaalde, vaak voor alle standen gelijke boeten stellen.

De rechtspraak was in handen van de hoogste standen. Dat in geschillen tusschen hoog en laag de onpartijdigheid geen waarborg had, behoeft geen betoog.

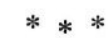

In de dagelijksche omgangsvormen komt het verschil in stand eerst recht tot uiting. Nu klagen de oudere vorstentelgen en hoofden, en ook de oudere menschen van minderen stand, dat de manieren van tegenwoordig zooveel te wenschen over laten. Ik geloof zeker, dat deze ouderen geen ongelijk hebben. De omstandigheden hebben zich evenwel zoo sterk gewijzigd, dat vele omgangsvormen uit den tijd raken.

Wanneer voor eenige decenniën een mindere een meerdere op zijn pad ontmoette, dan steeg de mindere van het paard en bracht zijn kleeding in orde. Hij zorgde, dat, zoo hij het bovenlijf ontbloot had, de sarong onder de oksels was samengebonden en de tepels niet zichtbaar waren, of, zoo hij een jas droeg, dat de sarong stevig, zooals het behoorde om het middel zat. In geen geval mocht het broekje, dat hij er onder droeg, gezien worden. Ook zijn hoofddoek of het gevlochten kalotje, de songko, moest behoorlijk zitten. Hij liet ruim baan aan den meerdere, die hem passeeren zou en zoo het een der hoogste leden van het vorstenhuis of een voornaam hoofd was, zou hij zich het liefst aan het gezicht onttrekken, door zich in het struikgewas te drukken. In dat geval behoorde hij te hurken en niet op te zien naar den voornamen voorbijganger. - Thans moet de voornaamste edelman, indien hij zich te paard waagt op de groote wegen in Zuid-Celebes, goed oppassen, dat hij met paard en gevolg en al niet in de sloot raakt vanwege de groote autobussen, die, vol met ,minderen”, langs de asfaltwegen jagen. Het steeds toenemende verkeer heeft gemaakt, dat vreemdelingen, in voorheen vrijwel gesloten gemeenschappen, dagelijksche verschijnselen zijn geworden. ()ok hierdoor daalde het gezag der hoofden, daar dit op het vreemde element slechts weinig vat heeft, en verloor ook de étiquette veel van haar strengheid.

Vroeger moest een ieder voor den edelman gereed staan, en als men niet voor hem gereed stond, welnu, de kleine man had misschien 
wel wat geld in zijn buidel, voldoende, of misschien zelfs meer dan voldoende om een flinke boete te betalen voor zijn onbeleefdheid. Hieruit begrijpe men niet, dat men thàns in het algemeen niet voor den edelman gereed wil staan, doch het misbruik, dat de adel van zijn positie maakte, is tegenwoordig tot een minimum beperkt.

Een onbeleefdheid was en is overigens gauw begaan. De arme, die op het onverwachtst een gezelschap ,anakaraëngs", die op de hertenjacht waren, moest herbergen, moest zorgen, dat de hooge gasten in ruime mate te eten kregen. Sirih, eten en drinken, diende op een bepaalde wijze te worden aangeboden, terwijl de hooge gasten door de jonge dochters des huizes moesten worden bediend. De hooge gast krijgt soms, niet overal, niet één, doch meerdere borden en twee koppen - zoo de gastheer deze bezit - voor zich. Ik herinner mij, dat ik, op een tocht in de bergstreken van Sindjaï, even uitrustende bij het hoofd van een kleine nederzetting, twee koppen koffie voor mij kreeg. De koppen waren zeer groot en gebloemd. De bestuursassistent, die mij vergezelde, kreeg ook twee koppen, maar deze waren kleiner en niet gebloemd, terwijl de „Aroe” van die streek, die ons begeleidde, twee heel kleine glazen kopjes kreeg. De gastheer zelf had één kop. Doch het fijn gevoel voor rang en stand, dat vermoedelijk 's mans fort was, uitte zich niet alleen in het aantal en de soort van koppen, die ieder zijner gasten werd aangeboden. Want hijzelf zat op den naakten vloer. De Aroe op een oud matje. De bestuursassistent op een nieuw matje, en ik op een melkkistje, waarover twéé nieuwe matjes.

In de nabijheid van een hoogere rechtop staan, valt den Makassaar en den Boeginees moeilijk. Richt een edelman het woord tot een, als gids vóór hem loopenden man uit het volk, dan ziet men den laatsten een lichten schok krijgen en een weinig gebukte houding aannemen. Eischt het gesprek, dat hij stilstaat, dan wendt hij zich in nederiggebukte houding om, zelden den edelman vol, doch meestal onderuit aanziend. Wordt het een eenigszins lang gesprek, dan zal het van de zijde van den minderen man niet vlotten, vóór hij goed en wel op den grond zit. In den omgang van twee edellieden zal men aan vele kleine nuances in gebaar, stem en gesprek kunnen bemerken, wie het zuiverste bloed heeft, hoewel ook verschil in leeftijd zich vaak op dezelfde wijze uit.

Ook aan de kleeding is standsverschil te onderscheiden, alhoewel hier eveneens veel is veranderd en nog steeds verandert, daar de 
Europeesche tropenkleeding onder het jongere geslacht, voornamelijk in de hoogere standen in de kuststreken, meer en meer de inheemsche kleedij verdringt, terwijl de Gouvernements-ambtenaren van hoog tot laag over het algemeen Europeesch gekleed gaan.

Het is niet mijn plan de kleeding der Boegineezen en Makassaren uitvoerig te bespreken.

Slechts de verschillen in kleeding, voorzoover deze samenhangen met den stand der dragers, zal ik aangeven.

De gewone man draagt een eenvoudigen hoofddoek, meestal zeer slordig om het hoofd gewonden. Oude mannen uit het volk ziet men wel eens grof-gevlochten ,songko's”, een soort kalotjes, vervaardigd van de nerf van het lontarblad, dragen. De laagste hoofden, eveneens uit het volk afkomstig, dragen ook gaarne deze „,songko's”, evenals de lage Mohammedaansche godsdienstbeambten.

De mannen uit de hoogere standen dragen bijna zonder uitzondering de ,songko'”, doch dan van fijne kwaliteit en dikwijls vervaardigd van paardehaar en doorvlochten met zilver- of gouddraad. Voorts dragen sommige edellieden gaarne den gesteven hoofddoek, op een bepaalde wijze om het hoofd gewonden met één punt recht in de hoogte. Gedurende een hertenjacht mag deze hoofddoek ook door den medejagenden gewonen man gedragen worden.

De gewone man draagt een sarong van geruit katoen in allerlei kleuren, hoewel zijde hem, althans tegenwoordig, niet verboden is. Den gezeten, niet-adellijken handelaar of handwerksman ziet men vaak zijden sarongs dragen. Soms hebben bepaalde adellijke families bijzondere kleurcombinaties in hun, altijd geruite, sarongs. Dit is tenminste in Gowa het geval. Door de vrouwen in de eene familie worden altijd sarongs geweven, waarin bijvoorbeeld steeds weer een bepaald soort blauw, een bepaald soort groen en een bepaald soort rose voorkomt, - evenwel nooit in hetzelfde patroon, daar de eene sarong nimmer geheel gelijk wordt gemaakt aan de andere -, terwijl een tweede familie meer paars en rood in de sarongs heeft. Van een ongeschreven wet was hier echter geen sprake. Als morgen aan den (lag de vrouwen anders willen gaan weven, kunnen zij dit doen. Dezen indruk heb ik althans gekregen.

Slechts met één kleur moet de mindere man en de mindere vrouw voorzichtig zijn; het geel is namelijk de kleur der vorsten. Niemand zal er aan denken een gele sarong, of een sarong, waarin veel geel verwerkt is, te gaan dragen, tenzij hij een vorst, een kroonprins of een rijksbestierder is. Ook een broeder of een oom van den vorst 
zal het geel wel kumnen dragen, doch andere edellieden dan de vorstentelgen van het zuiverste bloed, die ten nauwste aan den regeerenden vorst verwant zijn, zullen dit altijd nalaten. Ik herinner mij uit Gowa, dat toen allang geen vorst meer had, een typeerend voorval. Op zekeren dag zag ik, uit het raam van mijn kantoor kijkend, op straat een man loopen, die een helgele sarong droeg, nonchalant om het middel gedrapeerd. Ik liet den bestuursassistent roepen en wees hem den man, terwijl onder de menschen, die altijd het erf van een controleurskantoor bevolken: politieagenten, lagere hoofden, getuigen in rechtszaken, een lichte opschudding merkbaar was. Nauwelijks had de bestuursassistent den man gezien, of hij zei zeer laconiek: „Een krankzinnige, mijnheer”. En inderdaad bleek na onderzoek, dat de man een uit een ander ressort afkomstige, overigens ongevaarlijke krankzinnige was. De gele sarong was voor den bestuursassistent voldoende geweest, om een volkomen juiste diagnose te stellen omtrent een hem geheel onbekend persoon.

Het standsverschil komt minder in het dagelijksche leven dan op groote feesten - als huwelijks- en besnijdenisfeesten in adellijke kringen - in de kleeding tot uiting. De mannelijke leden van den hoogen Gowaschen adel - nergens wordt van feestkleedij nog zooveel werk gemaakt als in Gowa - zijn dan gekleed in een prachtig brokaat jak, versierd aan hals en onderarmen met juweelen of filigraan-gouden knoopjes. $\mathrm{Zij}$ dragen daarbij dan in plaats van een sarong, de ,gadoe”, een wit-gazen rok, en de ,sigara”, een lage witte ,,songko", van satijn. Oude edellieden dragen bij het brokaat jak ook wel een zwart-gazen rok of een donkere met schelpen geglansde sarong. Deze drachten mogen door minderen nimmer gedragen worden, tenzij zij, althans in Gowa, in het huwelijk treden. Bruid en bruidegom dragen vorstelijke kleedij. Ook de boodschapper, doch dit komt minder vaak voor, die de bruiloftsgasten gaat uitnoodigen, mag gekleed gaan in ,gadoe”, heeft, evenals de bruidegom, het bovenlichaam naakt, en draagt de ,sigara” ${ }^{1}$ ). De bruidegom heeft een soort band om het hoofd, die weer dezelfde band is, die ook de meeste vorsten van Zuid-Celebes bij hun inhuldiging dragen.

De vrouwen onderscheiden zich weinig van elkander. De vrouwen van adel dragen meer zijde, doch over het algemeen is er geen verschil in kleeding, naar gelang er standsverschil bestaat. Toch,

1) Matthes vermeldt echter in zijn Mak. Wdb. en Boeg. Wdb. dat de „sigara" zoowel door vorsten als geringen wordt gedragen, doch alleen bij feesten. 
dit zij hier terloops opgemerkt, herkent men de vrouw van adel onmiddellijk. Dikwijls heeft zij zeer fijne gelaatstrekken en is zij blank van huid, omdat deze nimmer aan de zon wordt blootgesteld. Zij heeft mooi-gevormde, op haar wijze gesoigneerde handen en soms ontstellend kleine voeten, daar zij zeer weinig loopt. Soms heeft zij nog nooit den grond betreden, omdat zij altijd buitenshuis gedragen is geworden of te paard heeft gezeten. $\mathrm{Zij}$ is over het geheel tengerder en eleganter dan de gewone vrouw en haar haardracht is veel verzorgder. Tusschen de wijze, waarop zij en die waarop de gewone vrouw, dezelfde kleeren zonder eenige snit en meestal van dezelfde stof, draagt, bestaat een hemelsbreed verschil. Ik zag dit eerst, toen een van mijn Boegineesche vrienden mij hierop opmerkzaam had gemaakt. Het gold toen nog wel een vrouw van hoogen en een vrouw van minder hoogen adel, de laatste afkomstig uit de bergen - wat altijd een minderwaardigen klank heeft. De adellijke jonge vrouw uit de bergen geleek een onhandige stumper tegenover de Watamponeesche dame, hoewel deze reeds op leeftijd en eenigszins gezet was.

Rijdt een vrouw paard, dan zit zij op kussens en hoe hooger de stand der vrouw, des te meer kussens op den rug van het paard zijn vastgesnoerd. De vorstinnen van Bone en Soppeng zitten op zeven kussens.

Ten slotte nog iets over het huis en zijn bouw naar gelang van den stand van den bewoner.

Alle Boegineesche en Makassaarsche woningen staan op palen. Ziet men vijf bij vijf palen onder een huis staan, dan is de bewoner iemand van adel. Is het antal geringer, dan kan er ook iemand uit den gewonen stand in wonen. Hoe meer palen, hoe meer vakken, waarin het huis verdeeld is, hoe hooger de stand. Het aantal palen, dat een regeerend vorst van een der ,botjo's" onder zijn huis kan laten zetten, is onbeperkt.

Een edelman en dan meestal een voornaam edelman, heeft geen gewone trap aan zijn huis, doch men begeeft zich langs een schuinliggend, gevlochten bamboedek, (Boeg. en Mak. „sapana”) naar binnen.

Ook het aantal ",samboenglayang”, kleine afdaken onder de nok van het dak aan den voorgevel, houdt verband met den stand van den bewoner. De gewone man behoort niet meer dan twee ,samboenglayang" aan zijn huis te hebben. Een vorstelijke woning telt er 
evenwel vijf, een woning van een voornaam hoofd of edelman vier, en een van een lager edelman drie.

De palen onder het huis en de ,samboenglayang” aan den voorgevel zijn tegenwoordig evenwel, wat men zou kunnen noemen, prijsgegeven door den adel; liever nog, de mindere standen hebben er zich meester van gemaakt. Rijke burgers zetten huizen met veel meer palen er onder, dan volgens hun stand geoorloofd is.

Een ander kenmerk van een vorstelijke of adellijke woning is een overdekt toegangspoortje tot het erf, waarop de woning staat. Dit ziet men evenwel weinig meer.

Slechts een regeerend vorst mag een woning met twee daken hebben.

Voorts dragen slechts woningen van vorsten en voorname hoofden boven in den voorgevel een versiering in den vorm van een karbouwenkop met groote horens.

Als vroeger iemand het waagde bij den bouw van zijn huis iets aan te brengen, wat voor een hoogeren stand was weggelegd, dan werd het huis in brand gestoken door de soldaten van den vorst. Ik zeide reeds, dat, wat het aantal palen onder een huis en het aantal „samboenglayang” betreft, de oude adat in verval is geraakt. Doch niemand zal het heden ten dage wagen een huis te bouwen met zeven bij zeven palen, vijf ,,samboenglayang”, twee daken, de „sapana” en den buffelkop. Tenzij hij waarlijk een Boegineesch of Makassaarsch vorst is.

Ik wil er hier bepaaldelijk de aandacht op vestigen, hoewel het uit het voorgaande wel gebleken zal zijn, dat bij de Boegineezen en Makassaren niet aan iederen stand of tusschenstand zijn bepaalde plaats op het terrein van de huwelijksgift, de omgangsvormen, de justitie, de kleeding en den huizenbouw, valt aan te wijzen. De scheidingslijnen loopen nergens duidelijk. Wel teekenen zich overal de twee groote groepen af: de adel en het volk.

II.

Het economisch aspect dezer verhouding.

In het vierde hoofdstuk leerden wij de ,kasoewiyang” kennen als D1. 90. 
een stelsel van verplichte diensten, die eensdeels en vooral van economischen, religieuzen en socialen aard zijn en door den stand der vrijen in arbeid, voortbrengselen of geld worden gepresteerd ten behoeve van de boven hen gestelde regeerders, en anderdeels meer van politieken aard zijn en door hoofden in natura en arbeid worden gepresteerd ten behoeve van hoogere hoofden en vorsten. Na de uitvoerige behandeling van de ,kasoewiyang”, die ook in dit hoofdstuk, dat immers de verhouding der standen ten opzichte van elkander tot onderwerp heeft, in het geheel niet zou hebben misstaan, kan ik met een korte belichting van de economische beteekenis van dit stelsel van verplichte diensten, volstaan.

Ten aanzien van de voedselvoorziening (I. 1, 5; II. 1, 3, 4, 6, 7, $8,9,11,12$; VIII), als van den huizenbouw (I. 2; VIII), en van de geldelijke inkomsten (II. 2, 4, 5; III. 3) zijn, zooals wij zagen, vorsten, rijksgrooten en hoofden afhankelijk van de vrijen. Wanneer wij nu weten, dat niet slechts vorsten, rijksgrooten en hoofden met hun gezin van al deze diensten en heffingen profiteerden, doch dat groote scharen van meer of minder verre familieleden en verwanten op den zak teerden van hen, voor wie ,kasoewiyang” werd gepresteerd, dan komt de economische beteekenis van dit stelsel in een nog helderder licht te staan. Het is zonder twijfel herhaaldelijk voorgekomen en in sommige streken was het ook regel, dat de vrijen niet alleen „,kasoewiyang" verrichtten voor den vorst, doch dezelfde diensten, zij het dan ook op veel beperkter gebied, rechtstreeks aan diens neef, diens achterneef of een adellijken gunsteling bewezen, al waren deze dan ook niet met regeermacht bekleed. Deze toestanden, die vooral in de voornaamste rijken bestonden, werden als wantoestanden en uitvloeisels van machtsmisbruik beschouwd. Zeer natuurlijk is het evenwel, dat de regeerders in het onderhoud voorzien van die leden hunner verwantengroep, die niet met regeermacht zijn bekleed. De geheele adel groepeerde zich om de vorsten, de rijksgrooten en de hoofden en was economisch van hen afhankelijk. Wat wil dit zeggen ? Dat de adelstand economisch dreef op den stand der vrijen. De economische beteekenis van de betrekkelijk kleine groep der slaven mag hier gerust worden uitgeschakeld.

De inkomsten van de vorsten, rijksgrooten en hoofden werden niet alleen door de ,kasoewiyang” bepaald. Zoo hadden vorsten en rijksgrooten recht op een zeker gedeelte van de proceskosten der voor de 
hoogste rechtbank behandelde zaken en van de door haar opgelegde boeten. De hoofden trokken op dezelfde wijze inkomsten uit de rechtspraak der lagere colleges. Voorts hadden de vorsten van Bone en Gowa voor de aan hen onderhoorige gebieden den verkoop van opium aan zich getrokken. Zij lieten ook tegen betaling van eenige rijksdaalders scheepspassen uitreiken aan de in hun rijken thuishoorende prauwvaarders. Vóór 1893 behoorde aan den vorst van Gowa het monopolie van alle in Gowa geteelde koffie; daarna werd door den vorst, tot 1905, van het product uitvoerrecht geheven naar rato van de marktwaarde ${ }^{1}$ ). Dit koffiemonopolie is thans nog niet vergeten; het werd uitermate streng gehandhaafd: ontduikingen werden zwaar, soms met den dood gestraft. Het monopolie was dan ook in hooge mate winstgevend voor den vorst, hetgeen begrijpelijk is bij een door den vorst aan de bergbewoners betaalden, door hemzelf vastgestelden prijs van f 16 . - tot tot f 24 .- per pikoel en een gemiddelden verkoopsprijs van f 30.- De bekende koning I Koemala (1825-1893), na zijn dood „Toemenanga-rikakoasanna”, ,de in zijn waardigheid overledene" genoemd, bracht deze cultuur tot grooten bloei. Eerst tijdens zijn regeering kon het Gowasche vorstenhuis ook in Westersche oogen eenigszins vermogend worden genoemd.

Een vorst, een rijksgroote of een hoofd, die in verhouding tot zijn onderdanen niet rijk genoemd kan worden, is in de oogen van Makassaren en Boegineezen een paskwil. Een hoofd behoort een grooter huis te bouwen dan zijn onderdanen; een vorst bewoonde, zooals vanzelf spreekt, de grootste woning van het land. Als vorsten of hoofden een feest geven, is het gewoonte, dat slechts de allerhoogste gasten een uitnoodiging ontvangen. Verder is een ieder, hoog of laag, welkom. Op zulke feesten werden vroeger, en worden thans ook nog wel, duizenden en duizenden gespijzigd; honderden buffels werden geslacht, duizenden bossen rijst gestampt.

Een vorst moest altijd in overdaad leven en niet alleen een vorst, doch ook diens bloedverwanten. Deze overdaad, deze totale afwezigheid van materieele zorgen, moest blijken in onbeperkte gastvrijheid, in groote feesten - in de eerste plaats ter eere van de rijkssieraden -, en in veelheid en pracht van sieraden. Vroeger gold ook het bezit van vele vuurwapenen als een bewijs van grootheid en rijkdom. Bak-

1) Eerdmans, „Het Landschap Gowa”, Verh. Bat. Gen., 1897, deel L, 3e stuk. 
kers ${ }^{1}$ ) vertelt, dat de Boegineesche groote er trotsch op was en het als een rijkdom beschouwde, wanneer zijn wapenkamer met allerhande soorten van draagbare vuurwapenen was volgepropt. In de meeste gevallen was evenwel de voorraad van dien aard, dat die alleen kon beschouwd worden als te bestaan uit staatsie-, maar niet als uit verdedigingswapenen. „Het eerste,” zegt Bakkers, „heeft dan ook meer dan het laatste plaats; want het behoort alsmede tot de kenmerken der grootheid van een vorst of prins, dat hem op iederen togt, dien hij onderneemt een groot aantal geweerdragende manschappen voorafgaat, waaronder men er echter niet zelden aantreft wier geweren zonder sloten, of waarvan de sloten met bindrotting aan de lade bevestigd zijn."

Onder den laatsten vorst van Bone, Lapawawoï, hadden de mannelijke leden van den décadenten Boneschen hofadel minstens één beruchten opiumschuiver in hun gevolg, als een levend bewijs, dat zij èn rijk èn royaal waren. Een opiumschuiver heeft immers voortdurend behoefte aan veel geld en blijft slechts bij dien heer, die hem dat in ruime mate verschaft. Vaak schoven de heeren zelf geen opium. Dit maakte het ,houden” van een opiumschuiver des te aantrekkelijker, daar dan het element van verkwisting, van het nuttelooze weggooien van geld, nog duidelijker was.

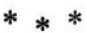

Een enkel woord over stand en beroep. Na de uitvoerige behandeling van de waardigheden, ambten en beroepen, die door adel en vrijen worden bekleed en uitgeoefend, zij volstaan met de opmerking, dat het geheele economische leven in al zijn geledingen zich eigenlijk afspeelt in den stand der vrijen. De adel verricht geen handenarbeid uitgezonderd goudsmidswerk, spin- en weefwerk en ,,alami”-vlechtwerk. Op de sawahs en de akkers werkten en werken de edellieden slechts in den hoogsten nood, een nood, die in den huidigen tijd begrijpelijkerwijs meer voorkomt dan vroeger. Wel waren de meeste edellieden grootgrondbezitter. Sommige edellieden voelden zich aangetrokken tot den handel; deze zijn er nu ook. Er waren en er zijn er die handelsvaartuigen bezaten en bezitten. Doch dat is dan ook al.

1) „Het leenvorstendom Boni”, blz. 87. 


\section{III.}

Het religieus aspect van deze verhouding.

In den loop van deze verhandeling bestond reeds de wenschelijkheid om verschillende punten van het religieuze aspect van de onderlinge verhouding der standen uitvoerig te behandelen. Ik wijs op de hemelsche afkomst der vorsten- en hoofdengeslachten en op den band, die bestaat tusschen de groepen der vorstentelgen van zuiveren bloede en de zuivere leden der hoofdengeslachten eenerzijds en de rijkssieraden anderzijds. De verhouding van den stand der vrijen tot de rijkssieraden werd nog niet uitdrukkelijk besproken, al kwam de voornaamste trek hiervan reeds naar voren: de trek namelijk, dat, terwijl de regalia in handen behooren te zijn van de hoogste groep in de gemeenschap, waarbij deze regalia behooren, het geheele aan deze regalia verbonden ritueel verricht wordt door vertegenwoordigers van den stand der vrijen. De priesters, de ,bissoe's”, de „sanro's” en de "pinati's”, hebben de leiding en verrichten dan het voornaamste ceremonieel, in kleine gemeenschappen eigenlijk al het ritueel. In Gowa zagen wij in de „Toekadjannangang” een organisatie van vrijen voor het verrichten van de lagere, aan het ritueel voor de rijkssieraden verbonden werkzaamheden.

De priesters zijn leden van den stand der vrijen. Al het ritueel bedrijf bij feesten van welken aard ook, bij ziekte, overlijden en begrafenis, bij rijst- en maisbouw, vóór verre reizen en belangrijke ondernemingen, was vroeger en is nog grootendeels in hun handen.

In het vorige hoofdstuk zagen wij, dat nog een tweetal beroepen van ongetwijfeld min of meer religieuzen aard, - al werd dit toen niet uitdrukkelijk in het licht gesteld -, verbonden zijn aan den stand der vrijen. Het waren de beroepen van danseres en tamboer. Hoewel thans vaak, op het oog, het vermaak dienende, komen bij nadere bestudeering tal van trekken te voorschijn, die wijzen op een belangrijke ceremonieele taak, zoowel in het geheel der crisisceremoniën als bij de feesten in verband met de rijkssieraden.

$$
* * *
$$

De crisis-ceremoniën zijn voor alle standen, op eenige uitzonderingen na, dezelfde, met dien verstande, dat bij de hooge standen de feesten en plechtigheden uitgebreider, kostbaarder en langduriger zijn. Deze feesten en plechtigheden hebben plaats bij geboorte, bij het voor 
de eerste maal knippen van het haar, bij het tandenvijlen en bij de besnijdenis, bij huwelijk en bij overlijden. Het tandenvijlen is thans in sommige streken reeds geheel verdwenen; het raakt hoe langer hoe meer in onbruik.

De uitzonderingen, waarop ik doelde, zijn : ten eerste het voor het eerst eten van vast voedsel en ten tweede het voor het eerst betreden van de aarde door kinderen van vorsten en andere hoog-adellijke personen. Ik zelf ben nimmer in de gelegenheid geweest feesten ter gelegenheid van deze gebeurtenissen bij te wonen. De adel mist de middelen om deze feesten naar behooren te vieren, vandaar dat deze steeds sporadischer voorkomen. Bakkers geeft van beide feesten een korte beschrijving in zijn artikel over Bone ${ }^{\mathbf{1}}$ ).

Mij rest nog te wijzen op het feit, dat de hooge Mohamedaansche godsdienstambtenaren als de „,kali” van Gowa en de ,kali” van Bone in den vorstentijd, zoo niet tot den hoogsten stand, dan toch tot een der hoogste tusschenstanden behoorden. De ,imangs”, de in rang op de ,kali's” volgende godsdienstambtenaren, zijn vaak leden van hoofdengeslachten.

\section{ZESDE HOOFDSTUK.}

Eenigegevolgtrekkingen.

I.

Alvorens ik het waag, den lezer in dit slothoofdstuk eenige gevolgtrekkingen voor te leggen, wil ik hem waarschuwen, dat ik dit doe in alle bescheidenheid. De samenleving, waarvan ik den belangrijksten socialen groepeeringsvorm in de voorafgaande bladzijden beschreef, is allerminst primitief te noemen. $\mathrm{Zij}$ is gecompliceerd en het dooreenliggen van heterogene verschijnselen maakt bestudeering aantrekkelijk, doch niet gemakkelijk. Doch dat is het minste. De grootste moeilijkheid, die de samenstelling dezer verhandeling medebracht, was het feit, dat ik, het materiaal in Zuid-Celebes zelf verzamelende, van den waren ethnograaf alleen het enthousiasme bezat. Ik was

1) „Het leenvorstendom Boni”. blz. 119 e.v., 121 e.v., ook 41 e.v. 
volstrekt ongeschoold. Dat daardoor terreinen ononderzocht bleven, die een geroutineerd ethnoloog nimmer links zou hebben laten liggen. is begrijpelijk. Ik hoop alleen, dat deze terreinen niet vele zijn. Dat ik een onbeschreven blad was, levert misschien dit ééne voordeel op, dat van vooroordeel bij dezen ethnograaf toch zeker geen sprake kon zijn.

In de vorige hoofdstukken streefde ik het hoofddoel van deze verhandeling na: ik trachtte zoo overzichtelijk mogelijk alle gegevens betreffende de standen bij de Boegineezen en Makassaren te groepeeren. De lezer zal reeds bemerkt hebben, hoeveel in deze samenleving dooreen leeft, dat in verschillende sferen moet zijn ontstaan; hoeveel uit vroegere tijden, al is het dan vaak vervormd, nog voortbestaat, terwijl de organisaties, waarvan het deel uitmaakte of waaruit het groeide, reeds lang afgestorven zijn en vervangen werden door andere. Hij zal gezien hebben, dat deze samenleving, waaraan men zoo gaarne de termen „,monarchie”, ,despotisme” en „, feodaal” verbindt, niet zoo gernakkelijk met zulk een enkel étiket kan worden gekenschetst. Hieronder willen wij trachten eenige verheldering te brengen. Wij zullen pogen perspectief te brengen in de gegevens, de verschillende belangrijke verschijnselen naar voren te halen, na te gaan of en in hoeverre zij in eenig onderling verband tot elkander staan en of zij wellicht niet behooren in heel andere sfeer, dan waarin wij hen thans ontmoeten. Wij zullen trachten deze verschijnselen naar hun aard en oorsprong te waardeeren. Mocht ik er in slagen een tip op te lichten van den sluier, die tot dusver hing over deze zoo belangwekkende maatschappij, dan zal dit te danken zijn, eensdeels aan het werk van Durkheim en Mauss ${ }^{1}$ ), anderdeels aan dat van drie Nederlandsche ethnologen: Prof. Dr. J. P. B. de Josselin de Jong ${ }^{2}$ ), Mr. F. D. E. van Ossenbruggen ${ }^{3}$ )en Dr. W. H. Rassers ${ }^{4}$ ).

1) E. Durkheim et M. Mauss. „De quelques formes primitives de classification”, l'Annèe sociologique, VI (1903), blz. 1-72. - M. Mauss. „Essai sur le don, forme et raison de l'échange dans les sociétés archaïques", l'Année sociologique, nouv. série I (1925).

2) J. P. B. de Josselin de Jong. ,De oorsprong van den goddelijken bedrieger”, Med. Kon. Akad. v. Wetensch., afd. Lett. 68, serie B. No. 1 (1929). „The Natchez social system”, Proceedings of the Twenty-third International Congress of Americanisis, Sept. 1928. blz. 553 e.v.

3) F. D. E. van Ossenbruggen. „De oorsprong van het Javaansche begrip Montjå-pat in verband met primitieve classificaties", Versl. en Med. Kon. Akad. v. Wet., afd. Lett. 5de Reeks, Deel III (1917), blz. 7 e.v.

4) W. H. Rassers. „De Pandji-roman” (Diss. Leiden 1922). — „Over den zin van het Javaansche drama”, Bijdr. tot de Taal-, Land- en Volkenkunde van 
II.

Aan het einde van het eerste hoofdstuk, waarin de indeeling in standen werd behandeld, concludeerden wij, dat de BoegineeschMakassaarsche maatschappij verdeeld is in drie hoofdgroepen en wel : de groep der vorstentelgen van zuiveren bloede, de groep der vrijen en de groep der slaven. De hoofdengeslachten vormen geen stand tusschen de groep der vorstentelgen van zuiveren bloede en die der vrijen in, doch een nevengroep van de eerste, zij het op lager niveau. Dit bleek ook ten duidelijkste bij de afzonderlijke behandeling van de hoofdengeslachten in het derde hoofdstuk.

In het vierde hoofdstuk werd de slavenstand uitvoerig besproken. De daarin voorkomende gegevens wettigen thans de gevolgtrekking. dat de stand der slaven niet op één lijn mag worden gesteld met de twee andere hoofdgroepen, namelijk in dezen zin, dat de slavenstand eigenlijk secundair is. Dit blijkt uit het feit, dat de drie bronnen van slavernij: de menschenroof, de oorlog en de rechtspraak, tenslotte gevoed werden, òf door volksgroepen buiten de Boegineesch-Makassaarsche maatschappij, òf door een der hoogere standen, waarbij eigenlijk slechts de stand der vrijen beteekenis had. De slavenstand had geen wezenlijke taak in het leven der maatschappij. Rechten bezat hij in het geheel niet, en evenmin verplichtingen tegenover de gemeenschap als zoodanig. Indien wij den slavenstand uitschakelen, -- waartoe wij thans het recht hebben -, dan zien wij door heel Zuid-Celebes een tzveedeeling. De groepen, die elkander aanvullen en steunen, zijn de eerste twee hoofdgroepen uit ons schema: (A) de groep der zuivere vorstentelgen met daarnaast de hoofdengeslachten, en daartegenover (B) de groep der vrijen.

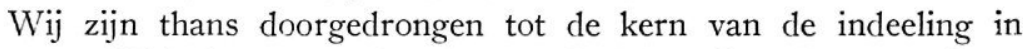
standen. Vóór het zoover kon komen, hadden wij veel op te ruimen en te ordenen. De pandelingen zetten wij al heel spoedig terzijde; de tusschenstanden maakten wij tot wat zij in wezen zijn: tusschenstanden; de hoofdengeslachten, in essentie niet verschillend van de vorstengeslachten, werden gezet waar zij behoorden: naast de vorstentelgen van zuiver bloed; de priesters en de krijgsoversten, door verscheidene auteurs zoo gaarne als afzonderlijke standen ge-

Ned.-Indië, Deel 81, derde en vierde afl. (1925), blz. 311 e.v. - „Over den oorsprong van het Javaansche tooneel", Bijdr. tot de Taal-, Land- en Volkenkunde van Ned.-Indië, Deel 88, 3de afl. (1931), blz. 317 e.v. 
qualificeerd, bleken daartoe niet alleen alle eigenschappen te missen, doch zeer bepaaldelijk te behooren tot een der eerstgenoemde twee hoofdgroepen: de priesters bij de groep der vrijen, de krijgsoversten in beginsel bij de groep der vorstentelgen van zuiveren bloede en de hoofdengeslachten. Tenslotte lieten wij den slavenstand, als zijnde secundair, vallen.

Zou de tweedeeling, die wij langzamerhand te voorschijn hebben gebracht, de sleutel zijn tot het probleem van den oorsprong van dit standensysteem?

Laat ons afwachten. Eerst zullen wij dit probleem van verschillende zijden trachten te benaderen.

\section{III.}

Het is uit het, door Matthes in het Boegineesch gepubliceerde, La-Galigo-epos ${ }^{1}$ ) voornamelijk de scheppingsmythe, waarmede dit gedicht aanvangt, die ons kosthaar materiaal schenkt. Dit La-Galigoepos is uit ethnologisch oogpunt zonder twijfel het meest waardevolle stuk, dat in de beide Chrestomathieën van Matthes voorkomt. Ik gevoel mij ten eenenmale onbevoegd een vertaling van dit wezenlijk schoone voortbrengsel der Boegineesche literatuur te leveren. Doch dat niet alleen. Dit heldendicht is zoo uitgebreid en bevat zooveel interessants, dat vertaling en commentaar een lijvig boekdeel zouden vullen. Ik moet volstaan met het samenvatten van het voornaamste, dat deze scheppingsmythe inhoudt.

„De Oppergod des Hemels, Patoto', hetgeen wil zeggen: „de Beschikker van 's menschen lot" ${ }^{2}$ ), ook genaamd To-palanrowé, „,de Schepper" ${ }^{2}$ ), belegt op zekeren dag, na zijn gemalin Datoe-Palingé' te hebben geraadpleegd, een grooten familieraad in den hemel. Op Patoto's verzoek zijn daar mede aanwezig de Oppergod van de Onderwereld, Goeroe-ri-Sĕllěng, en zijn gemalin, Sinaoe-todja, ,die

1) Dr. B. F. Matthes, Boegineesche Chrestomathie, II, Makasser, 1864, 2de uitg., A'dam, 1872. B1z. 416-547, aant. 250-263. Prof. Jonkers noemde in de Encyclopaedie van Ned.-Indië (onder Boegineesch), de voorstelling, dat er één gedicht van dien naam zou bestaan, dat dan van een bijzondere uitgebreidheid zou zijn, minder juist. Wel kan men van een bepaalden stijl spreken, welke dan kenmerkend is voor heldendichten, die, naar een persoon, die in sommige episoden den hoofdrol vervult, den naam dragen van La-Galigo-gedichten.

2) Vertaling van Matthes. 
door het water overschaduwd wordt", ${ }^{1}$ ) dus onder water woont. Deze zijn door zes hemelen gereisd, teneinde den zevenden, waar Patoto' met zijn gemalin in het paleis Roewalětté, resideert, te bereiken. In al deze hemelen heerschen zoons van den hemelschen Oppergod en zijn gemalin. In den eersten hemel woont in het paleis Lĕttěnrioe, Balasariwoe, ook genaamd Adjipalloerĕng, die den donder en den bliksem maakt. In den tweeden hemel woont in het paleis Mallagěnni, Dĕttia Tana, ook genaamd Adjitěllino, die een ijzeren berg beheerscht. In den derden hemel woont in het paleis Malimongěng, I Lasangiyang, die hanengevechten houdt met zijn volk. In den vierden hemel woont in het paleis Langkoe-Langkoe, Adjipawewang, die een land maakt. In den vijfden hemel woont in het paleis Limpomadjang, Sangiyangkapa, ook genaamd Adjipatongĕng, die de sterren regelt, terwijl in den zesden hemel, in het paleis Wawo-öenroe, woont Laroempa(ng)mega, ook genaamd Adjipalallo of Lamega-adji, wiens taak niet vermeld wordt. Het hemelsche Oppergodenpaar heeft in het geheel negen zoons, waarvan er drie nog niet genoemd zijn. De oudste van allen is Latogě-Langi-Batara-Goeroe of BataraGoeroe. Voorts wordt als de zevende zoon Dettia-Oenroe of DatoeMalĕbbi genoemd, terwijl Patara-Oenroe of Adjimangkaoe de jongste zoon is.

Goeroe-ri-Sĕllĕng en Sinaoe-todja hebben negen dochters, waarvan de oudste is We-Nji'li-timo' Tompo'é-ri-boesa-empong, hetgeen wil zeggen: ,de uit het schuim der golven opgekomene” ${ }^{1}$ ). $\mathrm{Z}_{\mathrm{ij}}$ is de aanstaande vorstin van Toda-todja, wat een andere naam voor Paratiwi of Peretiwi of Onderwereld is. De tweede is Linroetalaga, vorstin van Oeri-lioe, een land in de Onderwereld. De derde is Sangiyamparě, vorstin van het land, dat vooraan in de Onderwereld ligt. Haar witte haren zijn als alang-alang. De vierde is vorstin in het land Samoedaë, eveneens in de Onderwereld gelegen, en is geheeten Laweroilě. De vijfde is Dĕttia-Langi, vorstin van Todassolo en de zesde I Lasamoeda, vorstin van Marawannang. De zevende is Lawero-öenroe. Haar rijk wordt niet bij name genoemd, doch is gelegen in de Onderwereld, achter den Hemel. De achtste is I Lasanĕdda, vorstin van het rijk Woeloewongěng in de Onderwereld. De jongste wordt niet bij name genoemd, doch haar rijk is het dichtst bij de aarde en zij is het, die springvloeden veroorzaakt, schepen doet vergaan, menschen mishandelt, karbouwen en herders doet schrikken en menschen in het woud doet verdwalen.

1) Vertaling van Matthes. 
Patoto' is de tweelingbroeder van Sinaoe-todja, de gemalin van Goeroe-ri-Sĕllĕng, terwij1 Datoe-Palingé' de tweelingzuster van Goeroe-ri-Sěllěng is. Patoto' is bovendien een ncef van Goeroe-riSĕllĕng.

In den familieraad komt men, in overleg met de broeders, zusters, neven, nichten (,,cousins” en ,cousines”, „neveux” en ,nièces”), ministers en andere raadslieden, overeen, den cudsten zoon van Patoto' en Datoe-Palingé', Batara-Goeroe, naar de woeste en ledige aarde te doen afdalen, teneinde een voor de menschen herbergzaam oord te scheppen. Hij zal de oudste dochter van Goeroe-ri-Sěllĕng, We-Nji'li-timo' tot gemalin krijgen. Zij beiden zullen de eerste menschen zijn.

De Oppergod van den Hemel is hooger in rang dan die van de Onderwereld. Patoto' verzoekt Goeroe-ri-Sěllěng met zijn gemalin op te stijgen naar den Hemel en onverwijld begeeft dit echtpaar zich op weg. Ook in de wijze, waarop Patoto' de leiding heeft in de gesprekken, welke in den familieraad worden gevoerd, blijkt dit ten duidelijkste. Bovendien is Patoto' ouder dan Goeroe-ri-Sĕllĕng.

Patoto' geeft aan Batara-Goeroe een krisband, een hoofddoek, een armband en den ring van een vinger van zijn rechterhand. DatoePalingé' schenkt haar scheidenden zoon een ring van haar linkerhand. Voorts laat Patoto' Batara-Goeroe meenemen de plantensoorten „,talěttimpěrě”, ,,siri”, ,,atakka”, „,těllě”, ,araso”, een arēnpalm, gepofte rijst van het hemelland Lĕttĕnrioe en verschillende soorten rijst van het hemelland Sawangkoetoe.

Vervolgens bindt Patoto' zijn oudsten zoon, met alles wat deze mede moet nemen, in een bamboekoker en laat hij hem langs den regenboog naar de Aarde afdalen. Op zijn weg naar de Aarde, halverwege gedaald, laat Batara-Goeroe, naar zijns vaders bevel, de „,talěttimpĕrĕ” zakken, waaruit dan landen, bergen, velden, zeeën, meren, rivieren, eilanden en stranden ontstaan. Daarna strooit hij rechts van zich de ,atakka” en links de ,tĕllě” uit. Hieruit ontstaan de wouden. Bijna op aarde aangekomen, laat hij den arēnpalm vallen. Deze verandert in een slang en eenige andere dieren. De rijst, zoowel de gepofte als de andere, verandert dan in een zwerm vogels.

Zeven dagen blijft Batara-Goeroe zonder eten en drinken in zijn bamboekoker op de aarde liggen. Dan pas springt de bamboe open en kan hij opstaan. Al spoedig wordt hij dan door Goeroe-ri-Sĕllĕng gehaald, om naar de Onderwereld te komen en daar zijn bruid te ontmoeten. Deze zal naar de Aarde komen, zoodra deze bewoonbaar 
is. Batara-Goeroe keert naar de Aarde terug en daar er nu reeds negen dagen verloopen zijn, zonder dat hij heeft gegeten of gedronken, smeekt hij den Schepper hem aan te hooren en te vernemen in welke ellende hij verkeert. Patoto' zendt dan zeven „Oro”, zwarte menschen, met zeven bijlen om bosch te kappen, en daarna "bata", (maï), en ,wěttěng” (gierst) te zaaien. Daarna laat Patoto' neerdalen: een paleis, een ontvangzaal, een tamarinde-boom en een ,wodi"-boom, vijf bijvrouwen en alle zoogbroeders van BataraGoeroe. Het land, waar op deze wijze de residentie van Batara-Goeroe gesticht wordt, heet I.oewoe'.

Als alles gereed is, stijgt in het Oosten, uit zee, We-Nji'li-timo' op.

In de volgende jaren baren eerst de bijvrouwen van Batara-Goeroe verscheidene kinderen. Na lang wachten wordt ook We-Nji'li-timo' zwanger, en schenkt zij het leven aan een zoon: Batara-Lĕttoe. Bij de groote feesten, welke ter gelegenheid van deze gebeurtenis worden gegeven, spelen de ,bissoe's”, de priesters, daartoe uit het hemelland nedergedaald langs den I.atimodjong, het geweldige gebergte dat Loewoe' beheerscht, een groote rol.

Batara-lěttoe huwt met .We-Opoe-sĕngĕng, uit welken echt een tweeling werd geboren, waarvan de jongen heette Saweri-gading en het meisje We-Tĕnriijabeng. Daarna steeg Batara-Goeroe, vergezeld van zijn gemalin en zijn andere vrouwen, ten hemel, om daar voor goed te blijven".

Tot zoover de samenvatting van de voornaamste punten uit de scheppingsmythe.

$$
* * *
$$

Laat ons thans onderzoeken, wat deze mythe ons kan leeren.

Wat het meest naar voren treedt in dit verhaal is zonder twijfel de tweedeeling. Wij vinden tegenover elkander twee groepen: de Hemelgroep en de Onderwereldgroep, die tezamen een eenheid vormen. Dat zij een eenheid vormen, blijkt uit de zeer innige verwantschapsbanden, die tusschen de beide Oppergodenparen bestaan, en bovendien uit de gemeenschappelijkheid der beraadslagingen over een zaak van groot belang: het huwelijk van een lid van de eene, met een lid van de andere groep.

Deze beide groepen zijn exogaam. De Oppergod des Hemels heeft een vrouw gehuwd, wier broeder over de Onderwereld heerscht, terwijl de vrouw van den Oppergod der Onderwereld een zuster is van den Oppergod des Hemels. Wij kunnen deze groepen, ook zonder dat wij verder iets naders zouden te weten komen, reeds met alle 
recht betitelen als de helften van een stam, als „moieties”, als de beide phratries.

Deze gevolgtrekking vindt bij nadere beschouwing al spoedig bevestiging in het huwelijk van den oudsten zoon van het hemelsche godenpaar met de dochter van het godenpaar uit de Onderwereld. Dit huwelijk is namelijk een ,cross-cousin”-huwelijk bij uitnemendheid. Hij trouwt niet alleen met zijn moedersbroedersdochter, doch ook met zijn vaderszustersdochter. Deze beide mogelijkheden, die een „,cross-cousin"-huwelijk biedt, kunnen slechts vervuld worden bij een wederkeerig connubium, welk connubium bij uitstek bestaat, indien de stam in niet meer (lan twee phratries of clans is verdeeld ${ }^{\mathbf{1}}$ ).

1) $\mathrm{Bij}$ een systeem, waarbij de stam gevormd wordt door meerdere phratries of clans, zonder dat evenwel sprake is van een circuleerend stelsel, kan wederkeerigheid in het connubium altijd voorkomen.

Een eenzijdig connubium, inhaerent aan een circuleerend systeem, laat slechts de mogelijkheid van het „,cross-cousin"-huwelijk, waarbij de man zijn moedersbroeders-dochter huwt. Het andere ,cross-cousin"-huwelijk - man met vaderszustersdochter - is dan onmogelijk.

Voorbeeld I.

Twee-clan- of -phratriestelsel; moederzijdige afstamming.

$$
\begin{aligned}
& \text { Man } 1 \text { huwt vrouw } 2 . \quad \square=\text { man. } \\
& \text { " } 2 \text { " }, 1 . \quad-=\text { huwelijk. } \\
& \ldots \ldots=\text { broeder en zuster. }
\end{aligned}
$$

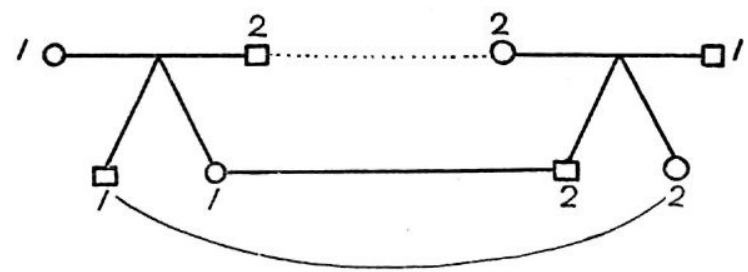

De man kan dus zoowel vaderszustersdochter als moedersbroedersdochter huwen. Anders gezegd, broeder en zuster kunnen in dezelfde clan huwen. Het connubium is wederkeerig.

Voorbeeld II.

Twee-clan- of -phratriestelsel; vaderzijdige afstamming. Verder zie Voorbeeld I.

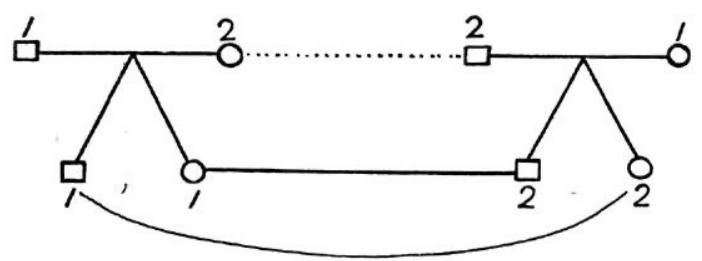

Conclusie als bij Voorbeeld I. 
Bezien wij de verhouding der beide groepen in dit licht, dan wordt ons ook duidelijk, dat zoowel Patoto' als Goeroe-ri-Sĕllĕng een ,crosscousin"-huwelijk hebben gesloten. Patoto' en Goeroe-ri-Sěllěng zijn neven; beiden zijn dus met hun nichten gehuwd. Deze nichten kunnen van haar echtgenooten onmogelijk ,parallel-cousins” zijn, d.w.z. zij kunnen ten opzichte van haar echtgenooten noch vadersbroedersdochter, noch moederszustersdochter zijn, daar zij dan zouden behooren tot dezelfde phratries als haar echtgenooten, hetgeen onbestaanbaar is. Wij moeten dus aannemen, dat Patoto' en Goeroe-riSěllěng met hun ,cross-cousins” zijn gehuwd, b.v. op de wijze als in onderstaand schema is aangegeven. Verondersteld wordt vaderzijdige afstamming.

V'oorbeeld III.

Meerdere clans of phratries doch geen circuleerend systeem.

De man moet buiten zijn phratrie of clan huwen; in welke phratrie of clan is onverschillig. Wederkeerigheid kan dus altijd voorkomen, doch is nooit regel.

Voorbee1d IV.

Circuleerend systeem; moederzijdige afstamming.

Man 1 huwt vrouw 2.

, 2 , " 3.

$" 3 \Rightarrow \quad " \quad 1$.

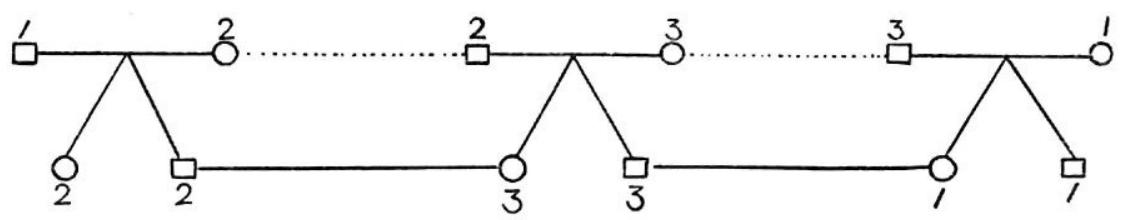

De man kan slechts moedersbroedersdochter huwen. Het andere „crosscousin"-huwelijk is uitgesleten. Broeder en zuster kunnen niet in dezelfde clan huwen. Het connubium is eenzijdig.

Voorbeeld V.

Circuleerend systecm; vadersijdige afstamming.

Verder zie Voorbeeld IV.

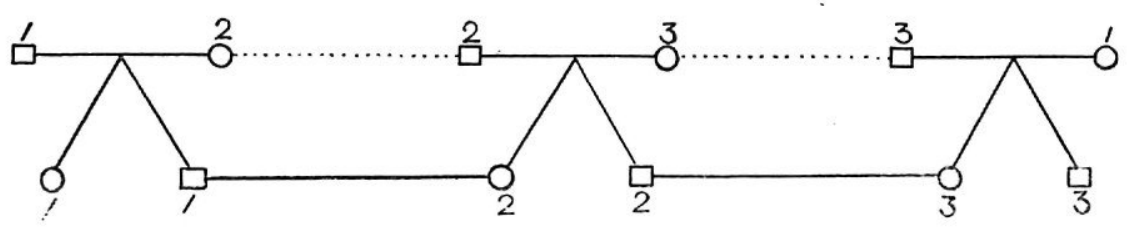

Conclusie als bij Voorbeeld IV. 


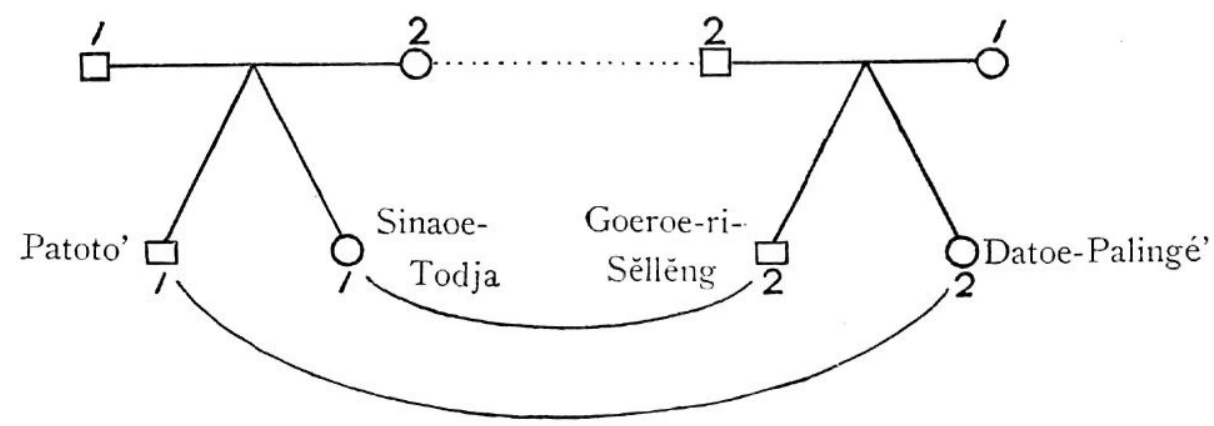

Ook in deze huwelijken komt het wederkeerig connubium ten sterkste tot uiting.

Voor hen, die meer gegevens zouden wenschen om mijn stelling, dat wij hier te doen hebhen met een wederkeerig connubium tusschen een Hemelphratrie en een Onderwereldphratrie, te kunnen aanvaarden, zal ik even deze scheppingsmythe verlaten. Het huwelijk van Batara-Goeroe en We-Nji'li-timo is namelijk niet het eenige duidelijke ,,cross-cousin”-huwelijk in de rij der afstammelingen van de Oppergodenparen van Hemel en Onderwereld. Wij rapen den draad waar wij hem loslieten: bij de geboorte van Saweri-gading en We-Tĕnriyabeng. Saweri-gading huwt met We-Tjoedai, die het leven schenkt aan La-Galigo en Simpoeroe-todja. Bovendien - volgens de geslachtslijst van de vorsten van Loewoe' ${ }^{1}$ ) - aan Patiyang-djala. Simpoeroe-todja huwt met den zoon van Saweri-gading's zuster WeTĕnriyabeng, genaamd Salinroeng-langi of Lĕtté-parěppa, met haar „,cross-cousin” dus. Ook de andere dochter van Saweri-gading, die met Těnriyabeng's zoon Simpoeroesiya(ng) huwt, trouwt met haar „,cross-cousin”. Dit laatste volgens de Loewoe'sche geslachtslijst.

Aan deze geheele mythe ligt een zeer bepaald systeem ten grondslag en aanvaarden wij eenmaal, op bovenstaande, naar mijn meening zeer afdoende gronden, als hoofdelement van dit systeem de indeeling van een stam in twee exogame deelen, dan wordt veel van wat eerst duister was, helder, en blijkt allerlei op het oog onsamenhangends te hooren in stevig verband.

1) Deze geslachtslijst, die overigens weinig meer geeft dan een rij van vorsten en vorstinnen in hun onderlinge verwantschapsverhouding, ontving ik, na het persklaar maken der voorgaande hoofdstukken, van Mr. J. Gerritsen. Hierop is Simpoeroesiya(ng) - zie blz. 476 en 477 - een man, en niet, zooals op blz. 477 vermeld staat, een vrouw. Op dit punt komt de Loewoe'sche lijst dus overeen met Matthes' verhaal - zie blz. 476, in tegenstelling met Matthes' mededeeling echter, vormt Simpoeroesiya(ng) niet het begin van een nieuwe periode, doch volgt hij onmiddellijk, als zoon van deze, op We-Těnriyabeng. 
Zooeven nam ik, de „cross-cousin”-huwelijken van Patoto' en Goeroe-ri-Sěllěng besprekende, als voorbeeld vaderzijdige afstamming. Bij een nader onderzoek van ons materiaal zullen wij evenwel tot het besluit moeten komen, dat de afstamming hier niet vader-, doch moederzijdig moet zijn. Om dit duidelijk te maken, kan nevenstaande geslachtslijst ${ }^{1}$ ) niet worden ontbeerd.

Patoto', het hoofd van de Hemelphratrie, heeft tot gemalin een vrouw uit de Onderwereldphratrie. Wie volgt hem op? Rĕmman-riLangi', die gehuwd is met We-Těnriyabeng. Dit wil zeggen, dat Rĕmman-ri-Langi' tot de Hemelphratrie moet behooren, hetgeen weer beteekent, dat zijn vrouw tot de Onderwereldphratrie behoort. Dit nu zou onmogelijk zijn, indien de afstamming vaderzijdig was. Aan de hand van de geslachtslijst kan ieder dit voor zich zelf nagaan. Als wij moederzijdige afstamming aannemen, wordt ons duidelijk, waarom Saweri-gading zijn overgrootvader Goeroe-ri-Sěllěng moet opvolgen : hij behoort tot de Onderwereldphratrie. Wij begrijpen nu nog meer. In een passage uit het reeds vaak genoemde heldendicht, wordt ons verhaald, hoe We-Tjoedaï geen lust had, om naar de Onderwereld af te dalen, toen Goeroe-ri-Sĕllĕng verlangde, dat zijn achterkleinzoon Saweri-gading hem zou opvolgen: zij behoorde tot de Hemelphratrie.

Simpoeroesiya(ng), zoo zagen wij reeds ${ }^{2}$ ), was van hemelsche afkomst. Dit beteekent niet, dat hij tot de Hemelphratrie moet behooren. $Z \mathrm{ijn}$ vader regeerde in den Hemel; zijn moeder was dus een lid van de Onderwereldphratrie. Zijn zoon Anakadji, wel tot de Hemelphratrie behoorende, huwt met We-Tappatjina. Als nu We-Tappatjina in Loewoe' bevallen is van een dochter en het kind op zekeren dag erg huilt, zingt de grootmoeder van vaderszijde een lied, waarin spottenderwijze gezinspeeld wordt op het geschenk, dat We-Tappatjina van haar moeder mede ten huwelijk kreeg. We-Tappatjina acht zich hierdoor beleedigd en vertrekt naar haar eigen land $^{3}$ ). Hier zien wij, meen ik, in een mythe tot uiting komen het antagonisme, dat over het algemeen leeft tusschen twee phratries: de grootmoeder van vaderszijde behoort tot de Hemelphratrie, We-Tappatjina, haar moeder en haar kind tot de Onderwereldphratrie.

1) Door mij samengesteld met gebruikmaking van de gegevens uit het LaGaligo-epos, na We-Tjoedaï's generatie angevuld met de gegevens van $\mathrm{Mr}$. J. Gerritsen.

2) Blz. 476 .

3) Blz. 476 . 


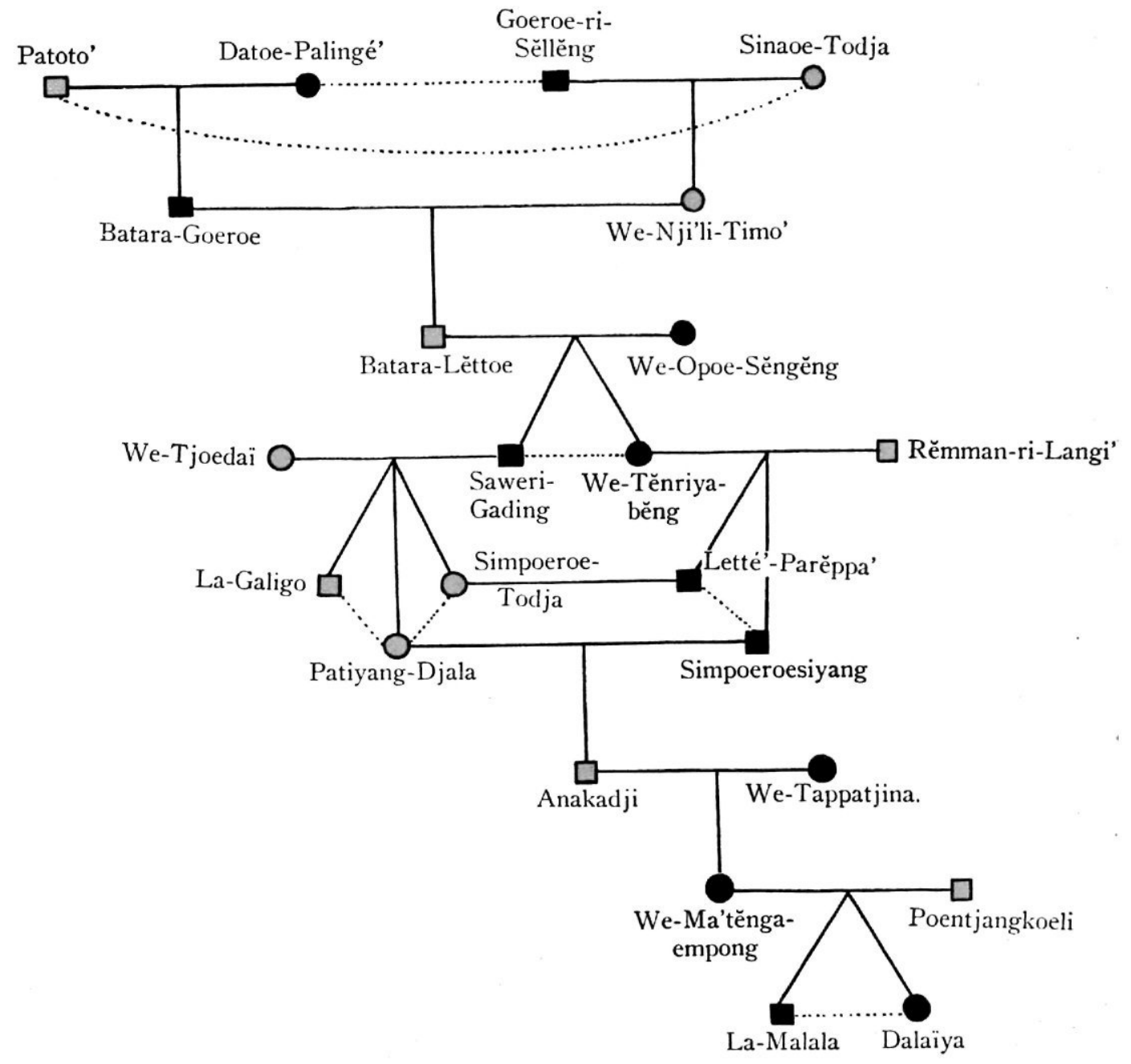

Man, Hemelphratrie.

- Man, Onderwereldphratrie.

O Vrouw, Hemelphratrie.

- Vrouw, Onderwereldphratrie.

- Huwelijk.

Broeder en Zuster. 
Wij herinneren ons nu ook, dat La-Malala, de zoon van WeMatěnga-empong, geen rust had vóór hij zijn zuster naar de Onderwereld mocht volgen ${ }^{1}$ ): hij behoorde tot de Onderwereldphratrie. $\mathrm{En}$ in de Bonesche afstammingsmythe kiest de vorst Laoemasě den soon van zijn zuster tot opvolger en noemt hem ook zijn zoon ${ }^{2}$ ). Zooals men ziet, wordt ten aanzien van deze moederzijdige afstamming de proef op de som slag op slag geleverd.

$\mathrm{Nu}$ eenmaal onze aandacht op deze deeling in twee phratries met moederzijdige afstamming is gevallen, zien wij nog meer. Van het echtpaar, waaruit, volgens de verschillende afstammingsmythen, die wij leerden kennen, de eerste op aarde geboren vorst of hoofd spruit, is altijd de vrouze uit den Hemel nedergedaald; òf zij alleen is ,Toema'noeroeng”, òf beiden zijn „Toe-ma'noeroeng” ${ }^{3}$ ). De Boegineesche en Makassaarsche vorsten en hoofden zijn allen van hemelschen oorsprong, omdat de stammoeders „Toe-ma'noeroeng” waren.

De scheppingsmythe laat onze aandacht echter nog niet los. Het hemelsche Oppergodenpaar heeft negen zoons, het Oppergodenpaar uit de Onderwereld heeft negen dochters. De eene phratrie is dus mannelijk in het classificatie-systeem, dat aan deze mythe ten grondslag ligt; de andere, de Onderwereldphratrie, is vrouwelijk.

Het getal negen kan het aantal clans voorstellen, waarin iedere phratrie weer onderverdeeld is, hoewel in alle mythen ook het getal zeven een belangrijke rol speelt. Ik denk aan de zeven hemelen, aan de zeven dagen, dat Batara-Goeroe hongerend en dorstend in zijn bamboekoker op de aarde ligt, (maar als hij zich tot den Schepper wendt heeft hij negen dagen gevast); aan de zeven zwarte menschen en de zeven bijlen, die Patoto' naar de Aarde zendt; aan de „Woromporong" ${ }^{1}$ ); aan de „Aroempitoe”, de Bonesche rijksraad van zeven ${ }^{2}$ ); aan het Kroningsfeest van Karampeloewa dat zeven dagen en zeven nachten duurde $\left.{ }^{3}\right)$; aan de zeven kinderen van de ,Toe-ma'noeroeng” van Borisallo ${ }^{4}$ ); aan de zeven vertrekken van het huis van Boronglowé $\left.{ }^{5}\right)$. Eigenlijk is hier zelfs een gissing zonder zin. De gegevens

1) Blz. 477 .

2) B1z. 473, 474 .

3) Gowa, blz. 470 e.v.; Bone, blz. 473; Soppeng, blz. 475; Borisallo, blz. 506;

Boronglowé, blz. 506 e.v.; Kalimporo, blz. 508; Bangkala, blz. 509.

4) Blz. 473 .

5) Blz. 512 .

6) Blz. 474 .

7) B1z. 506 .

8) Blz. 507

D1. 90. 
laten niet toe, dat wij hier eenige gevolgtrekking maken. Voorloopig zij in het voorbijgaan op dit punt de aandacht gevestigd.

Een belangrijke conclusie kunnen wij trekken uit de onderlinge verhouding van Patoto' en Goeroe-ri-Sěllěng ${ }^{1}$ ). Hieruit blijkt namelijk, dat de Hemelphratrie superieur is aan de Onderwereldphratrie. Dat Patoto' door Goeroe-ri-Sĕllĕng wordt aangesproken als „oudere broeder”, is in dit verband teekenend.

Het huwelijk is in de scheppingsmythe, en ook in de andere, in deze verhandeling opgenomen mythen, patrilocaal.

Wat de successie betreft: slechts mannen bestijgen den troon. doch in de r'rouzelijke lijn.

Alvorens wij onze analyse van de scheppingsmythe, - die wij tevens als uitgangspunt bezigden om dieper door te dringen in de stamoudersmythen van vorsten- en hoofdengeslachten - beëindigen, willen wij een aantal elementen aanwijzen uit het classificatie-stelsel, dat als het ware het geraamte vormt, waaromheen dit verhaal is opgebouwd. Deze elementen zijn het talrijkst voor de Hemelphratrie.

1) B1z. 585 . 
Hemelphratrie.

Hemel.

Mannelijk. ${ }^{1}$ )

Hoog. ${ }^{2}$ )

Lucht.

Donder. ${ }^{3}$ )

Bliksem. ${ }^{4}$ ).

Sterren. ${ }^{5}$ )

Berg. ${ }^{6}$ )

IJzer. ${ }^{6}$ )

Arenpalm. ${ }^{7}$ )

Slang. ${ }^{7}$ )

Haan. ${ }^{\text {) }}$

Tamarinde-boom. ${ }^{9}$ )

,Wodi"'-boom. ${ }^{10}$ )

Bamboe. ${ }^{11}$ )

Rijst. ${ }^{12}$ )

Gierst. ${ }^{13}$ )

Mais. ${ }^{14}$ )

Rechts. ${ }^{15}$ )

,Talěttimpěrě”. ${ }^{19}$ )

"Siri”. ${ }^{19}$ )

„Atakka”. ${ }^{19}$ )

,"Tĕllě”. 19

"Araso" 19

„Bissoe". ${ }^{20}$ )
Onderwereld phratrie.

Onderwereld.

Vrouwelijk. ${ }^{1}$ )

Laag. ${ }^{2}$ )

Zee. ${ }^{16}$ )

Water. ${ }^{17}$ )
Links. ${ }^{15}$ )

Oosten. ${ }^{18}$ )

Alang-alang. ${ }^{21}$ )

1) Blz. 591 .

2) B1z. 585 .

3) Blz. 584 .

4) Blz. 584 .

5) Blz. 584 .

6) Blz. 584 .

i) Blz. 585 .

8) Blz. 584 .

9) Blz. 586 .

10) Blz. 586.

11) Blz. 585.

12) Blz. 585.

13) Blz. 586.

14) Blz. 586.

15) Blz. 585 „Ring van Patoto's rechterhand en van Datoe-Palingé's linkerhand."

16) Blz. 584, 586 .

17) Blz. 584 .

18) Blz. 586.

19) B1z. 585.

20) Blz. 514, 579 en 586 .

21) Blz. 584. 
De scheppingsmythe uit dit La-Galigo-epos is uit ethnologisch oogpunt zeker het gaafste en belangwekkendste letterkundige voortbrengsel, dat de huidige Boegineesch-Makassaarsche samenleving kent. De andere mythen kunnen niet in haar schaduw staan. Toch toonen zij verwantschap. Hetzelfde rangschikkingsstelsel schemert in alle mythen door. De ,Toe-ma'noeroeng” dalen onder donder en bliksem neer, terwijl zij ook weder verdwijnen onder onweersverschijnselen ${ }^{1}$ ). De sterren vinden wij terug in de Bonesche mythe, waar de „Toe-ma'noeroeng” de eerste was, die de vlag ,Woromporong” ${ }^{2}$ ) bezat. De bamboe ontmoeten wij in de mythe van Bangkala ${ }^{3}$ ).

Geheel daargelaten het schabloonachtige en vrijwel inhoudslooze, dat een groot gedeelte van de nog levende mythen betreffende de afstamming der vorsten en hoofden kenmerkt, is het groote verschil tusschen de hier bèsproken scheppingsmythe en de andere in dit opstel opgenomen mythen, de eenzijdigheid, waarmede in deze laatsten slechts de Hemelgroep wordt belicht. Sporen van een tweedeeling zijn uiterst schaars, al zijn deze niet afwezig. Ik noem de beide „Toema'noeroeng" van Soppeng ${ }^{4}$ ), waarvan de eene heerscht over Westelijk, de ander over Oostelijk Soppeng. Ik herinner aan de twee zoons van „Goentoeroe' Mangoelappaka”, ,den Eeuwigdurenden Donder" en aan de twee deelen, waarin Boronglowé werd verdeeld ${ }^{5}$ ). In Kalimporo ${ }^{6}$ ) daalden twee ,Toe-ma'noeroeng” tegelijk neer: een man en een vrouw.

Tenslotte nog deze opmerking, waarmede ik dan — op zoek naar hoofdlijnen - de analyse van de scheppingsmythe en de andere mythen besluit. In de scheppingsmythe vond ik geen duidelijk verband tusschen de kleur geel en de Hemelphratrie. In andere mythen wordt deze kleur herhaaldelijk in verband met de ,Toe-ma'noeroeng” genoemd ${ }^{7}$ ).

$\mathrm{Na}$ deze poging, om door mythen-analyse nader te komen tot de oplossing van het probleem, dat ons bezighoudt, moeten wij toch zeker erkennen, dat de achtergrond dezer mythologie voor ons in

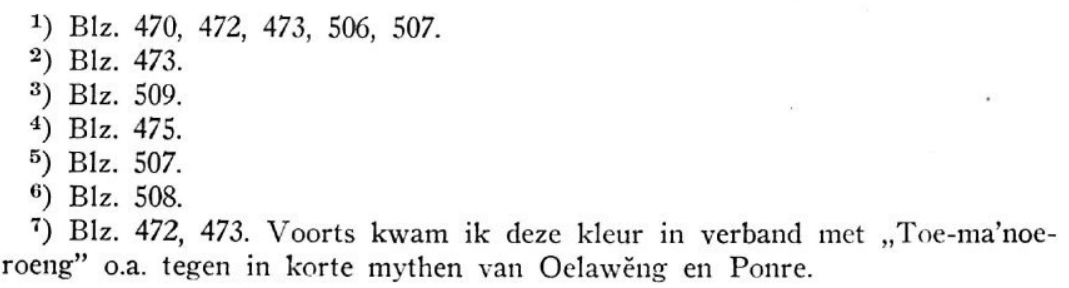


den loop van ons onderzoek steeds vastere omtrekken heeft aangenomen. Wij kunnen thans vaststellen, dat deze achtergrond is een sociale organisatie, waarvan wij de volgende kenmerken onomstootelijk hebben kunnen definieeren: (1) de tweedeeling, (2) de exogamie der stamhelften, (3) de superioriteit van de eene phratrie boven de andere, (4) de moederzijdige afstamming, (5) de patrilocaliteit des huwelijks, (6) het niet locaal gegroepeerd zijn der beide phratries, (7) de successie door mannen, in de vrouwelijke lijn.

Bovendien hebben wij eenige elementen uit een, met deze organisatie ten nauwste samenhangend classificatie-stelsel, kunnen ontdekken.

\section{IV.}

Wenden wij ons thans tot de tegenwoordige Boegineesch-Makassaarsche maatschappij. Een tzucedeeling leerden wij reeds onderkennen ${ }^{1}$ ). Doch hoe staat het met die verschijnselen, die wij zoo duidelijk en kenmerkend deel zagen uitmaken van de aan de scheppingsmythe ten grondslag liggende, sociale organisatie? Hieronder zullen wij gelegenheid hebben, deze vraag te beantwoorden.

Ik geloof, dat het overbodig is, na al wat in de voorgaande hoofdstukken ter kenschetsing daarvan is bijeengebracht, nog nader in te gaan op de superioriteit van de eene groep: die der zuivere vorstentelgen en daarnaast de hoofdengeslachten, aan de andere: de groep der vrijen.

Het huwelijk is zoowel bij de Boegineezen als bij de Makassaren, - in de beschrijvende hoofdstukken was geen gelegenheid hier op te wijzen -, patrilocaal.

De indeeling in standen is een nict-locale groepeeringsvorm.

Bij de Makassaren zagen wij, dat de vrouwen van de successic uitgesloten zijn ${ }^{2}$ ). Bij de Boegineezen dat mannen en vrouwen den troon kunnen bestijgen, doch mannen de voorkeur hebben ${ }^{3}$ ).

In deze verschijnselen kunnen wij een onmiskenbare analogie constateeren tusschen de samenleving, die den achtergrond vormde van de huidige Boegineesch-Makassaarsche maatschappij. Op twee uitermate voorname punten evenwel, zien wij aanmerkelijke afwijking: in de eerste plaats ten aanzien van de huwelijksbetrekking tus-

1) Blz. 582, 583 .

2) Blz. 485, 488, 491, 511 .

3) Blz. 488, 490, 491, 511. 
schen de twee groepen, en in de tweede plaats wat betreft de afstamming.

Vonden wij in de scheppingsmythe twee phratries, dus exogame, unilaterale groepen, de standen bij de Boegineezen en Makassaren zijn, zooals wij zagen en met vele voorbeelden illustreerden, in beginsel endogaam ${ }^{1}$ ). De afstamming, - dit kwam in de voorgaande hoofdstukken nog niet uitdrukkelijk ter sprake -, is bilateraal: het kind is zoowel familie van den man als van de vrouw. Wij zeiden, lat de standen in beginsel endogaam zijn, doch dat de endogamie niet zoo streng is, dat man en vrouw niet in een andere groep, dan waaruit zij stammen, zouden mogen huwen ${ }^{2}$ ). Wij vestigden toen tevens de aandacht op de beperking, dat het huwen van een vrouw met een man uit een lageren stand verboden is.

Laten wij hierbij stilstaan en pogen eenig inzicht te verkrijgen in den aard van dit verbod. Dit verbod is uitermate streng. Niet alleen, dat een dusdanig huwelijk verboden is, doch geslachtelijke omgang tusschen een vrouw van hoogen stand en een man van lageren stand, is een der ernstigste misdrijven, die de Boegineesche en Makassaarsche samenleving kent. De gevolgen van dit misdrijf worden geacht de geheele gemeenschap te treffen, evenals dit tengevolge van incest het geval is. Wij belichtten dit voldoende ${ }^{3}$ ).

Zooals uitvoerig werd uiteengezet in het eerste hoofdstuk en duidelijk blijkt uit de bij dat hoofdstuk behoorende schema's, is het kind, geboren uit een verbintenis tusschen een man van adel, waartoe hier ook de tusschenstanden worden gerekend, en een lagere vrouw, lager in stand dan de vader en hooger in stand dan de moeder. Dit beteekent, dat de afstamming in dit geval nòch vaderzijdig, nòch moederzijdig is. Zou deze vaderzijdig zijn, zoo zou het kind tot den stand van den vader behooren, terwijl bij moederzijdige afstamming het kind in den stand van de moeder zou komen. Ondanks de superioriteit van den adel is het vaderzijdig afstammingsprincipe, al is dit aanwezig, niet sterk genoeg om het kind tot den stand van den vader op te heffen. Een kind kan nimmer tot de allerhoogste groep, die der vorstentelgen van het zuiverste bloed, behooren, zoo onk de moeder niet van het zuiverste bloed is. Mallinckrodt teekende aan ${ }^{4}$ ), dat een ,taoe pea nae"-man (B I a) kan trouwen met een ,.poewa-
1) B1z. 555 e.v.
2) B1z. 557 e.v.
3) Blz. 557 .
4) Blz. 558 . 
sagigi"'-vrouw (A IV), doch slechts wanneer hij een veel hoogeren dan gebruikelijken bruidschat betaalt. Geheel op het niveau van de vrouw komt hij daardoor niet, daar de uit zulk een huwelijk geboren kinderen tot de ,poewa si parapa” (AV) gerekend worden. Wanneer wij bedenken, dat de ,poewa si parapa” eigenlijk kinderen zijn, gesproten uit verbintenissen van „Ana matola padjoeng”-mannen (A II), dus nakomelingen van zuiver bloed van vorige vorsten, en slavenvrouwen (C), dan zien wij hoe sterk dit moederzijdig afstammingsprincipe is. Een vrouw uit een tusschenstand heft hier haar kind op tot een stand, waartoe normaal het kind behoort, dat een vorstentelg van zuiveren bloede tot vader heeft. Het moederzijdige afstammingsprincipe is sterker dan het vaderzijdige.

Niet alleen langs dezen weg moeten wij tot deze gevolgtrekking komen. Wij brachten reeds eerder het beginsel der kinderverdeeling ter sprake ${ }^{1}$ ). Bij scheiding kreeg de vrouw alle oneven kinderen, de man alle even kinderen. Had de man, de vrije (in Gowa en Bone) de huwelijksgift aan den meester der slavin voldaan, dan waren de oneven kinderen slaven en de even kinderen vrijen. Ook hier zien wij duidelijk een samengaan van moederzijdige met vaderzijdige afstamming. En weer is het moederzijdige stelsel sterker. De vrouw krijgt bij scheiding het ecrste kind, de man het tweede. Al had de man voor een slavin de hwwelijksgift betaald, dan nog was het eerste kind, volgende den staat van de moeder, voor den meester der slavin. het volgende pas voor den vader en zoo vervolgens. In Mandar, zegt Mallinckrodt, was bij onbetaalde huwelijksgift het derde kind alleen voor den vader, al waren er ook tien. In Bone en Gowa kwamen in dat geval alle kinderen aan den meester der slavin.

Dit alles wijst in de richting, dat de moederzijdige afstamming ouder is dan de vaderzijdige. Doch wat ons het doorslaand bewijs levert, is een aanteekening in het dagboek der vorsten van Gowa en Tello ${ }^{2}$ ). Wij vinden op bladzijde 32 van Ligtvoet's publicatie. onder het jaar 1671, Mohammedaansche tijdrekening 1082, het volgende, zooals het getranscribeerd is door Ligtvoet:

„13 Nozcêmberé, 10 Radjá, allo djoemá. Nanilesang ri Toere'ammenang-ri-Djoentana bitjara ilalanta tocmanabâi aná manggeja".

1) Blz. 480 en 560.

2) A. Ligtvoet. „Transcriptie van het Dagboek der Vorsten van Gowa en Tello met vertaling en aanteekeningen". Bijdr. tot de T., L.- en V. van Ned.Indië, IVde Volgr., IVde deel, 1ste stuk (1880). 
Dit wordt door Ligtvoet, terwijl hij zijn toelichtingen tusschen haakjes plaatst, op bladzijde 134 aldus vertaald:

„De bij ons bestaande bepaling, dat de vaders geen aandeel in de kinderen hebben wordt door Toewammenang-ri-Djoentana (Karaëng-Karoenroeng) afgeschaft. (Hieruit blijkt, dat Karaëng-Karoenroeng toen weder rijksbestierder was)".

Ik neem niet aan, dat een mijner lezers gelooft, dat vóór 13 November 1671, de afstamming, althans in Gowa, zuiver moederzijdig was en op en na dien datum niet meer, doch toch wil ik er de aandacht op vestigen, dat dit vorstelijk édict een merkwaardig teeken is van een samenleving in ontbinding of, wellicht beter, verandering. Het moet voor een ieder begrijpelijk zijn, dat zulk een uitspraak slechts door een vorst of rijksbestierder gedaan wordt, wanneer hij daarmede niet tegen de bestaande verhoudingen en toestanden ingaat. De vorst is, althans in de Indonesische wereld, de handhaver van de adat. Deze adat nu wijzigt zich over het algemeen onmerkbaar langzaam. Wij kunnen aannemen, dat, vóór de rijksbestierder van Gowa een aanleiding had zijn tol aan den nieuwen tijd te betalen, honderden jaren zijn verloopen, waarin de moederzijdige afstamming terrein verloor en de vaderzijdige haar eigen plaats ging eischen. Zeker is nu evenwel, dunkt mij, dat er een tijd heeft bestaan, waarin de afstamming unilateraal was en in het bijzonder moederzijdig.

Zijn wij reeds iets verder gekomen op den weg naar het inzicht in het verbod, dat ons bezighoudt? Naar mijn meening wel. Houden wij voor oogen, dat de moederzijdige afstamming terrein verloor, dan is het waarschijnlijk, dat deze verbonden was an een verdwijnenden of verdwenen socialen groepeeringsvorm, een groepeeringsvorm, die plaats heeft moeten maken voor een nieuwe: die der standen. Het verbod, dat, zooals wij zagen ${ }^{1}$ ), nu nog springlevend is, houdt dus hoogstwaarschijnlijk ten nauwste verband, niet met de verdwenen, doch met de opgekomen groepeeringsvorm. Het is aannemelijk, dat dit uitermate scherpe verbod een maatregel is om an een sterk verschijnsel, behoorende in een vroegere organisatie, een einde te maken. Dit verbod verbiedt, anders geformuleerd, de vrouw uit de adelsgroep om buiten die groep te huwen. Dit verbod, nog anders geformuleerd, is een gebod om binnen deze groep te huwen. Het is een gebod van strenge endogame strekking. En tegen welk verschijnsel zou dit

1) B1z. 557,558 . 
ingaan, als het niet was tegen de exogame drang van de andere groep?

De groep der vrijen moet dus exogaam zijn geweest naar de groep, die zich door een verbod van endogame strekking trachtte te beschermen, namelijk de groep van de zuivere vorstentelgen en de hoofdengeslachten. Het huwelijk van een man van adel met een vrouw uit den stand der vrijen werd evenwel niet verboden. Waarom niet? Omdat, - en zoo zien wij alles in elkander grijpen -, de afstamming moederzijdig was, en een huwelijk van een vrouw uit de hooge groep met een man uit de lage groep, de hooge groep met haar groeiende kastegeest, zvel, en een huwelijk van een man uit de hooge groep met een vrouw uit de lage groep, de hooge groep nict kon verontreinigen.

\section{V.}

De lezer zal bemerkt hebben, dat ik bij mijn analyse van de huidige Boegineesch-Makassaarsche samenleving angstvallig vermeden heb gebruik te maken van conclusies, die ons onderzoek van de scheppings- en andere mythen opleverde. Ik deed dit met opzet. $\mathrm{Nu}$ is het geen waagstuk meer om aan te nemen, dat de sociale organisatie, die wij zagen dat den achtergrond vormde van de scheppingsmythe, er een is, die eenmaal de tegenwoordige organisatie is voorafgegaan. Wij staan op stevigen grond. Tweedeeling, superioriteit van de eene groep boven de andere, patrilocaliteit des huwelijks, het niet-locaal zijn der groepen, dit alles hebben de beide organsaties gemeen. Bovendien vonden wij, waar wij eerst groot verschil meenden te zien, bij nadere beschouwing, in de huidige samenleving duidelijke teekenen van vroegere exogamie der beide groepen en moederzijdige afstamming.

Men zal mij wellicht zeggen, dat dit alles belangwekkend is, doch dat daarmede nog niet verklaard is, hoe een deeling in twee phratries zich zou hebben kunnen wijzigen in een deeling in twee standen.

Zekerheid, hoe zich deze verandering heeft voltrokken, zal vermoedelijk wel nimmer te verwerven zijn, doch een hypothese, die een zekere graad van waarschijnlijkheid bezit, en althans als werkhypothese niet aanstonds verworpen behoeft te worden, laat zich wel opstellen. Men moet evenwel bedenken, dat ik, door den korten tijd, die mij ter beschikking stond, niet in staat ben geweest, de naburige volken op het probleem, dat ons bezighoudt, te bestudeeren. Dat dit voor 
het opstellen van een hypothese een zeker beletsel is, in zooverre, da: geen volk volkomen aan zich zelf begrepen kan worden, zal een ieder inzien. Toch kan ik de verleiding niet weerstaan, om aan het einde van deze verhandeling, zij het dan ook naar bescheiden krachten, mede te helpen aan de oplossing van het vraagstuk, op welke wijze de huidige standenorganisatie bij de Boegineezen en Makassaren zich ontwikkeld zou hebben tit de dualistische organisatie, die, naar wij zagen, aan de tegetiwoordige maatschappij moet zijn voorafgegaan.

Wij zagen, dat veel gelijk bleef en ook, dat veel veranderde; doch de veranderingen waren niet dusdanig of het gelukte ons, aan te knoopen aan de voorafgaande organisatie. Eén voornaam punt van overeenkomst tusschen de deeling in twee exogame phratries en de huidige organisatie kwam nog niet ter sprake. Het zal van alle analogieën de laatste zijn, die ik aanwijs. In de scheppingsmythe vonden wij in de innige verwantschap tusschen de beide Oppergodenparen de eenheid van den stam verbeeld. De twee groepen, waarin de huidige Boegineesch-Makassaarsche maatschappij in wezen uiteenvalt, vormen tezamen eveneens een eenheid, in dezen zin, dat zij tegenover en naast elkander staan met ieder een eigen taak in de samenleving. Zij steunen elkander dáár, waar zij gesteund moeten worden. De eene groep, de superieure, heeft de regeermacht ${ }^{1}$ ), de rechtspraak ${ }^{2}$ ) en de oorlogsleiding ${ }^{3}$ ) in handen. De rijkssieraden bezit zij $^{4}$ ). De andere groep levert de priesters ${ }^{5}$ ), de danseressen ${ }^{6}$ ) en de tamboers ${ }^{7}$ ). $Z i j$ regelt het ritueel der rijkssieraden ${ }^{8}$ ) en dat verbonden aan de crisis-ceremoniën ${ }^{9}$ ). Zij voorziet in alle economische behoeften van de beide groepen $\left.{ }^{10}\right)$. Zij kiest, zij het ook langs omwegen, de boven haar gestelde vorsten en hoofden uit de superieure groep ${ }^{\mathbf{1 1}}$ ).

Het zal niemand bevreemden, dat ik van al deze, voor de groepen karakteristieke eigenschappen, aanneem, dat zij reeds in een of

1) Blz. 477 e.v.; 512 .

2) Blz. 580 .

3) B1z. 477 e.v.; 513 .

4) B1z. 491 e.v.; 513; 579 .

5) Blz. 514 e.v.; 579 .

6) B1z. $516 ; 579$.

т) Blz. $516 ; 517 ; 579$.

8) B1z. 514 e.v.; 530 e.v.; 579 .

9) Blz. $515 ; 579$.

10) B1z. 575 e.v.; 520 e.v.

11) Blz. 566. 
anderen vorm phratrieëigenschappen zijn geweest. Ook het geheele ,kasoewiyang”-stelsel acht ik geboren uit het huldebetoon, dat de eene phratrie verplicht was aan de andere, superieure, te brengen. Toen de adel steeds grootere macht kreeg, groeide het stelsel uit, tot het den buitensporigen omvang bezat, welke wij nog omstreeks 1900 in Zuid-Celebes aantroffen.

Want, - en dit is een zeer voornaam punt --, de superioriteit van de eene groep aan de andere is, in een proces dat eeuwen en eeuwen heeft geduurd, voortdurend gegroeid. Wat hiervan nu weer de oorzaken zijn geweest, moge thans in het midden worden gelaten, doch cen evenwichtstoestand, waarin de superieure groep de voornaamste hoofden leverde, de rechtspiaak in handen had en bovendien de orr'ogsleiding bezat, moet labiel zijn geweest en voorbeschikt on verbroken te worden. Waarbij dan de schaal steeds dieper is doorgeslagen ten gunste van de superieure groep. Hieruit kunnen wij dan verklaren den groeienden kastegeest, welke wij ten grondslag zagen liggen aan het verbod, als vrouw te huwen met een man uit lageren stand. Mèt de volledige exogamie der phratries moest, naar van zelf spreekt, de moederzijdige afstamming verdwijnen, althans plaats maken voor het vaderzijdig afstammingsprincipe. De kinderverdeeling ontstond als compromis dezer beide afstammingsstelsels en een half-heriditair systeem van tusschenstanden ontstond als compromis tusschen phratrie-exogamie en kastegeest. Met hun strenge patrilineale successie zijn de Makassaren reeds verder van de moederzijdige afstamming verwijderd, dan de Boegineezen ${ }^{1}$ ).

$$
* *
$$

Tenslotte nog eenige opmerkingen, die eigenlijk buiten het kader van deze verhandeling vallen.

Het is mijns inziens waarschijnlijk, dat de ,bissoe's" en de rijkssieraden, waaromtrent de gegevens op het oogenblik niet toelaten een eenigszins gefundeerd oordeel te vormen, van centrale beteekenis zijn geweest in de samenleving, voorafgaande aan de tegenwoordige, de samenleving dus, waarin de phratries nog ten volle functionneerden. Ik wijs er op, dat de ,bissoe's" uit den stand der vrijen voortkomen en in de scheppingsmythe met den Hemel geassocieerd waren,

1) Ik wijs er in het voorbijgaan op, dat de Islam in Zuid-Celebes kwam nà een patrilineale successie van dertien vorsten, zoodat het niet de Islam is geweest, die het vaderzijdige afstammingsprincipe gebracht heeft. 
hetgeen overeenkomt met hun tweeslachtig karakter: zij zijn meestal homosexueel, en, man zijnde, gekleed als vrouw. De rijkssieraden zijn ten nauwste verbonden met de ,bissoe's”, die het voornaamste ritueel daarvoor verrichten. Ook zij vertoonen een tweeslachtig karakter, daar zij zich in handen bevinden van de superieure groep, en het ritueel wordt verricht door de groep der vrijen. 